Prepared in cooperation with the North Carolina Department of Environment and Natural Resources 319 Nonpoint Source Program

\title{
Effect of Land-Applied Biosolids on Surface-Water Nutrient Yields and Groundwater Quality in Orange County, North Carolina
}

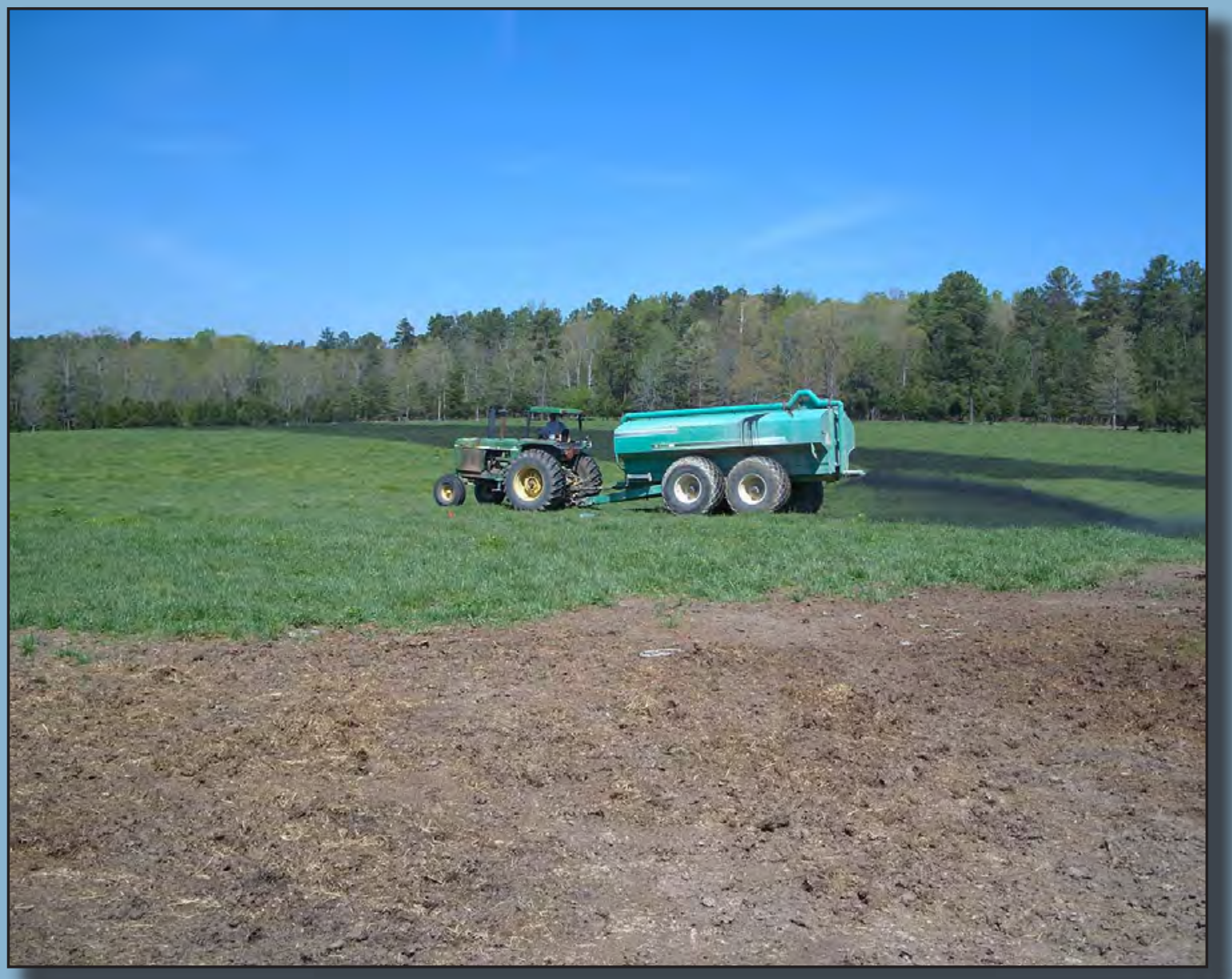

Scientific Investigations Report 2014-5240 


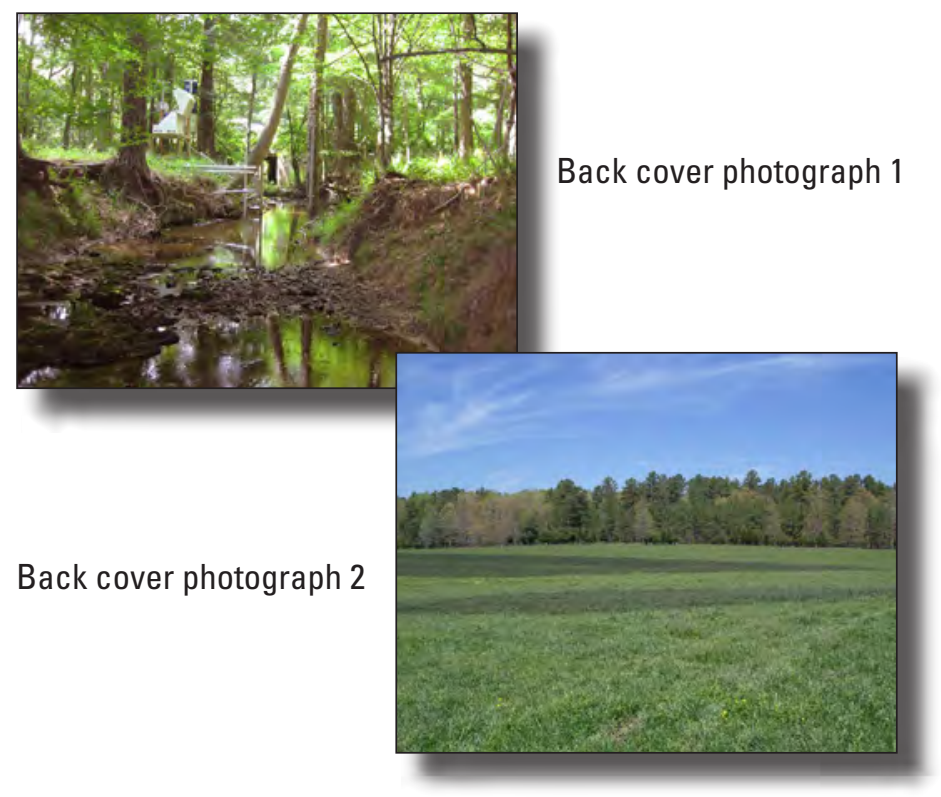

Front cover: Biosolids being land applied to an agricultural field in Orange County,

North Carolina, April 11, 2011. Photograph by Stephen Harden, U.S. Geological Survey.

Back cover photograph 1: U.S. Geological Survey water-quality monitoring station on Collins Creek at Highway 54 near White Cross, North Carolina, June 4, 2011. Photograph by Sean Egen, U.S. Geological Survey.

Back cover photograph 2: An agricultural field in Orange County, North Carolina, with recently applied biosolids, April 11, 2011. Photograph by Stephen Harden, U.S. Geological Survey. 


\section{Effect of Land-Applied Biosolids on Surface-Water Nutrient Yields and Groundwater Quality in Orange County, North Carolina}

By Chad R. Wagner, Sharon A. Fitzgerald, Kristen Bukowski McSwain, Stephen L. Harden, Laura N. Gurley, and Shane W. Rogers

Prepared in cooperation with the North Carolina Department of Environment and Natural Resources 319 Nonpoint Source Program

Scientific Investigations Report 2014-5240 


\title{
U.S. Department of the Interior SALLY JEWELL, Secretary
}

\section{U.S. Geological Survey Suzette M. Kimball, Acting Director}

\author{
U.S. Geological Survey, Reston, Virginia: 2015
}

For more information on the USGS - the Federal source for science about the Earth, its natural and living resources, natural hazards, and the environment, visit http://WwW.usgs.gov or call 1-888-ASK-USGS.

For an overview of USGS information products, including maps, imagery, and publications, visit http://WwW.usgs.gov/pubprod

To order this and other USGS information products, visit http://store.usgs.gov

Any use of trade, firm, or product names is for descriptive purposes only and does not imply endorsement by the U.S. Government.

Although this information product, for the most part, is in the public domain, it also may contain copyrighted materials as noted in the text. Permission to reproduce copyrighted items must be secured from the copyright owner.

Suggested citation:

Wagner, C.R., Fitzgerald, S.A., McSwain, K.B., Harden, S.L., Gurley, L.N., and Rogers, S.W., 2015, Effect of landapplied biosolids on surface-water nutrient yields and groundwater quality in Orange County, North Carolina: U.S. Geological Survey Scientific Investigations Report 2014-5240, 106 p., http://dx.doi.org/10.3133/sir20145240.

ISSN 2328-0328 (online) 


\section{Contents}

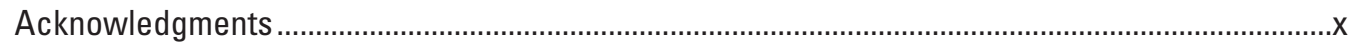

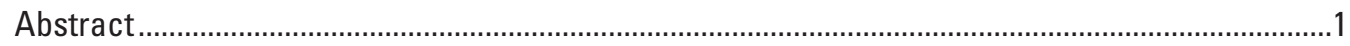

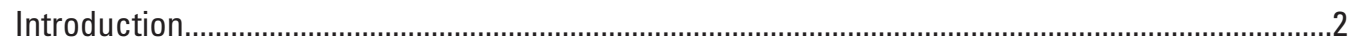

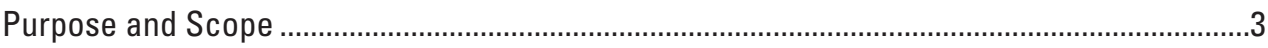

Description of the Study Area ..................................................................................................

Methods of Data Compilation and Analyses ......................................................................................10

Description of Study Sites and Field Data-Collection Activities .............................................10

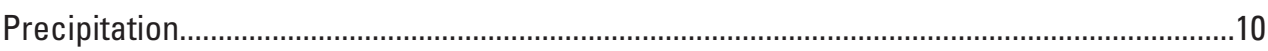

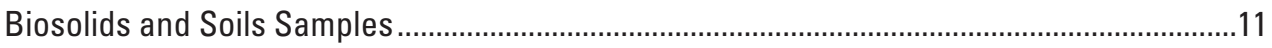

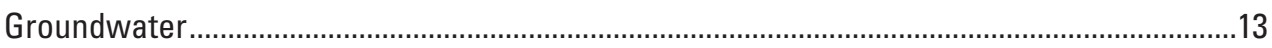

Groundwater-Level Monitoring .............................................................................14

Groundwater Sampling .................................................................................................

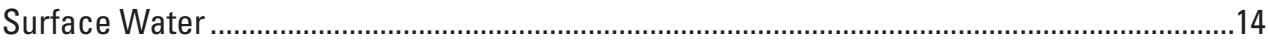

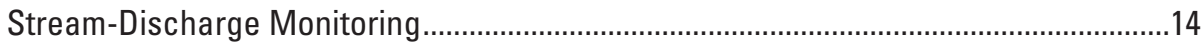

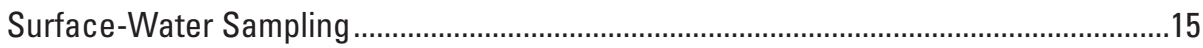

Laboratory Analyses.............................................................................................................. 15

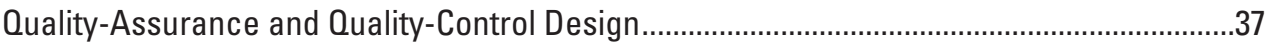

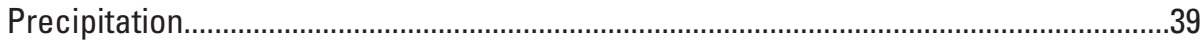

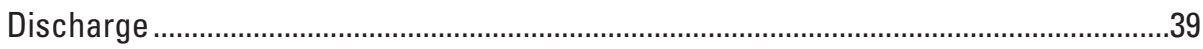

Statistical Analysis of Water-Quality Data ...................................................................................40

Surface-Water Load Computations .........................................................................................40

Effect of Land-Applied Biosolids on Surface-Water and Groundwater Quality...............................41

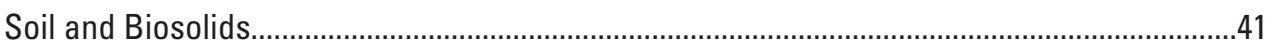

Summary and Comparisons of Constituent Concentrations.............................................42

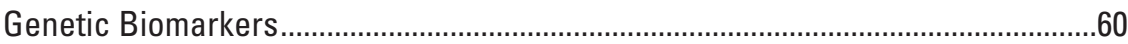

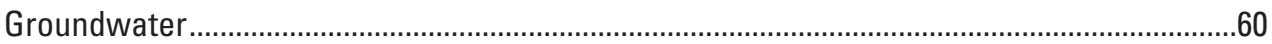

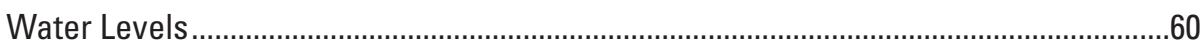

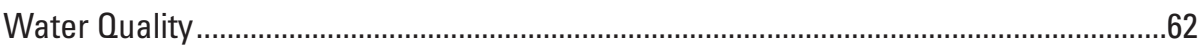

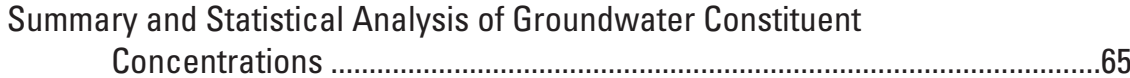

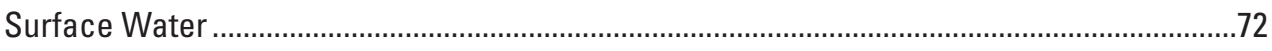

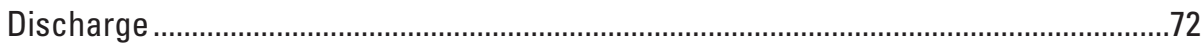

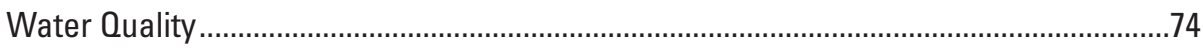

Comparisons of Surface-Water Quality ...................................................................74

Summary and Statistical Analysis of Surface-water Constituent

Surface-Water Loads and Yields ..................................................................88

Benthic-Macroinvertebrate Surveys ............................................................93

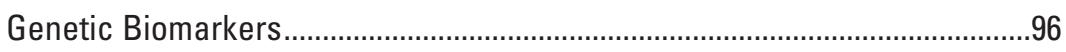

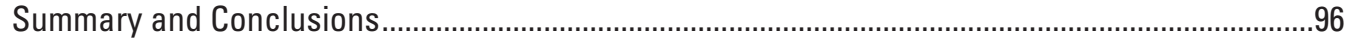

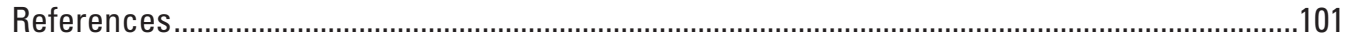




\section{Figures}

1-4. Maps showing:

1. The location of the Cane Creek and Collins Creek watershed study area in the Cape Fear River Basin, Orange County, North Carolina...

2. Locations of biosolids land-application fields and associated groundwater and surface-water monitoring sites in the Collins Creek watershed in Orange County, North Carolina

3. Locations of the background agricultural field and associated groundwater and surface-water monitoring sites in the Cane Creek watershed in County, North Carolina.

4. An example of the soil sampling grid at biosolids land-application field AF 11-6 in the Collins Creek watershed in Orange County, North Carolina. 12

5-9. Graphs showing:

5. Biosolids land-application volumes for 2010-13 for agricultural fields AF 11-2, AF 11-4, and AF 11-6 in Orange County, North Carolina.

6. Time series of concentrations of elements with U.S. Environmental Protection Agency ceiling concentrations for land-applied biosolids plus total Kjeldahl nitrogen, total phosphorus, and Escherichia coli, and fecal coliform in biosolids land-application fields and the background field in Orange County, North Carolina

7. Median concentrations of elements with U.S. Environmental Protection Agency ceiling concentrations for land-applied biosolids plus total Kjeldahl nitrogen, total phosphorus, and Escherichia coli, and fecal coliform in biosolids land-application fields and the background field in Orange County, North Carolina

8. Percentage of detections within the various analytical suites of contaminants of emerging concern in biosolids and soils in the Cane Creek and Collins Creek watersheds in Orange County, North Carolina.

9. Daily precipitation for U.S. Geological Survey rain gage maximum daily stage for a streamgage on Collins Creek, and water-level and groundwater sampling events for wells 0R-685, 0R-686, OR-687, 0R-688, 0R-689, and 0R-690, in Orange County, North Carolina

10. Map showing the water-level surface in the surficial aquifer in the Collins Creek watershed, Orange County, North Carolina, March 2013.

11. Water chemistry data from June 2011 to March 2013 displayed on a tri-linear Piper diagram from sampled wells and baseflow samples collected from U.S. Geological Survey streamgage and water-qualtiy monitoring site on Collins Creek in Orange County, North Carolina.

12-14. Graphs showing:

12. Concentrations of nitrate, sodium, total nitrogen, total phosphorus, Escherichia coli, fecal coliform, chloride, calcium, and potassium in wells OR-685, OR-686, OR-687, OR-688, 0R-689, and OR-690 in Orange County, North Carolina

13. Percentage of detections within the various analytical suites of contaminants of emerging concern in shallow groundwater samples from five monitoring wells in Orange County, North Carolina

14. Daily mean discharge hydrograph and stream sampling events for streamgages and water-quality monitoring sites at Cane Creek and Collins Creek in Orange County, North Carolina. 
15. Water chemistry data from December 2010 to May 2013 displayed on a tri-linear Piper diagram from streamgages and surface-water quality monitoring sites during baseflow conditions and stormflow conditions in the Cane Creek and Collins Creek watersheds in Orange County, North Carolina.

16-18. Graphs showing:

16. Nitrate, organic nitrogen, total nitrogen, total phosphorus, Escherichia coli bacteria, fecal coliform bacteria, chloride, calcium, potassium, and sodium concentrations in Cane and Collins Creeks, North Carolina..

17. Concentrations of nitrate, organic nitrogen, total nitrogen, total phosphorus, chloride, calcium, potassium, sodium, Escherichia coli, and fecal coliform bacteria in surface-water quality monitoring sites in the Cane Creek and Collins Creek watersheds, Orange County, North Carolina, in the winter/spring and summer/fall seasons...

18. Percentage of detections within the various analytical suites of contaminants of emerging concern in stormwater runoff surface-water samples from Cane Creek and Collins Creek in Orange County, North Carolina.

19. Hydrographs showing daily mean discharge, Escherichia coli yield, and fecal coliform yield for streamgages and water-quality monitoring sites: Cane Creek and Collins Creek in Orange County, North Carolina...

20. Graphs showing the relation of seasonal nutrient and streamflow yields for the Cane Creek and Collins Creek water-quality monitoring sites in Orange County, North Carolina

\section{Tables}

1. Data-collection network for the Collins Creek and Cane Creek study watersheds in Orange County, North Carolina..

2. Land-cover information for Collins Creek and Cane Creek surface-water monitoring sites in Orange County, North Carolina

3. Construction data for monitoring wells at the Collins Creek and Cane Creek watershed study sites in Orange County, North Carolina..

4. Media, analyzing laboratories, and types of quality-control samples analyzed for each constituent class.

5. Constituents measured in surface water and groundwater samples collected as part of this study and analyzed at the U.S. Geological Survey

National Water Quality Laboratory

6. Analytes measured in biosolids and soil samples collected as part of this study and analyzed at the U.S. Geological Survey National Water Quality Laboratory.

7. Constituents measured in surface water, groundwater, and biosolids and soils collected as part of this study and analyzed at laboratories other than the U.S. Geological Survey National Water Quality Laboratory.

8. Selected quality-assurance programs for water and solid phase chemical analyses operated by the U.S. Geological Survey Branch of Quality Systems and the National Water Quality Laboratory......

9. Constituents with high variability, low or incorrectly high recovery, and high bias in all media as determined by quality-control samples.

10. Summary of biosolids land-application dates and volumes for agricultural fields AF 11-2, AF 11-4, and AF 11-6 in Orange County, North Carolina, 2010-13.. 
11. Concentrations of U.S. Environmental Protection Agency-regulated constituents in land-applied biosolids, and total Kjeldahl nitrogen, total phosphorus, Escherichia coli, and fecal coliform bacteria in biosolids and pre- and post-biosolids application soil samples collected from agricultural fields AF 11-2, AF 11-4, AF 11-6, and the background field BF1 in Orange County, North Carolina

12. Percentage of elemental concentration in biosolids application fields that can be accounted for as biosolids addition

13. Number of detected individual contaminants of emerging concern in biosolids and soil samples collected from agricultural fields in the Cane Creek and Collins Creek watersheds in Orange County, North Carolina.

14. Concentrations of detected contaminants of emerging concern in biosolids and soil samples collected from agricultural fields in the Cane Creek and Collins Creek watersheds in Orange County, North Carolina.

15. Concentrations of hydrocarbons in biosolids and soil samples collected from agricultural fields in the Cane Creek and Collins Creek watersheds in Orange County, North Carolina.

16. Results of multiple comparison statistical testing for selected constituent concentrations among the six groundwater monitoring wells in Orange County, North Carolina..

17. Median concentrations of U.S. Environmental Protection Agency-listed contaminants with ceiling concentrations for land-applied biosolids and selected nutrients detected in groundwater samples collected at six monitoring wells in Orange County, North Carolina.

18. Concentrations of contaminants of emerging concern detected in groundwater samples collected at five monitoring wells in Orange County, North Carolina

19. Summary of streamflow data collected for the study period March 1, 2011May 31, 2013, at the monitoring sites on Cane Creek and Collins Creek in Orange County, North Carolina.

20. Concentrations of U.S. Environmental Protection Agency-listed contaminants with ceiling concentrations for land-applied biosolids and selected nutrients in storm event samples collected at Cane Creek, Collins Creek, and Collins Creek tributary sites in Orange County, North Carolina.

21. Concentrations of contaminants of emerging concern detected in surface-water storm samples collected at the Cane Creek and Collins Creek monitoring sites in Orange County, North Carolina.

22. Summary of total study period nutrient loads and yields for the Cane Creek and Collins Creek monitoring sites in Orange County, North Carolina...

23. Summary of seasonal nutrient loads and yields for the Cane Creek and Collins Creek monitoring sites in Orange County, North Carolina

24. Summary of fractions of seasonal nutrient loads during days when the streamflow is composed of greater than or equal to 75 percent baseflow, greater than 25 percent and less than 75 percent baseflow, and less than or equal to 25 percent baseflow for the Cane Creek and Collins Creek monitoring sites in Orange County, North Carolina.

25. Benthic community metrics at the Collins Creek and Cane Creek study sites in Orange County, North Carolina, sampled May 17, 2012.

26. Habitat and physiochemical properties measured at the Collins Creek and Cane Creek study sites in Orange County, North Carolina, May 17, 2012 


\section{Appendixes 1-4 (available at $h t t p: / / p u b s . u s g s . g o v /$ sir/2014/5240/}

1. Soil core lithologic descriptions

2. Solid-phase and water-quality data

3. Quality-assurance and quality-control section, with tables and figures

4. Surface-water loads calibration and prediction data

\section{Conversion Factors}

Inch/Pound to SI

\begin{tabular}{|c|c|c|}
\hline Multiply & By & To obtain \\
\hline \multicolumn{3}{|c|}{ Length } \\
\hline inch (in.) & 2.54 & centimeter $(\mathrm{cm})$ \\
\hline inch (in.) & 25.4 & millimeter $(\mathrm{mm})$ \\
\hline foot (ft) & 0.3048 & meter $(\mathrm{m})$ \\
\hline mile (mi) & 1.609 & kilometer $(\mathrm{km})$ \\
\hline \multicolumn{3}{|c|}{ Area } \\
\hline acre & 4,047 & square meter $\left(\mathrm{m}^{2}\right)$ \\
\hline acre & 0.4047 & hectare (ha) \\
\hline acre & 0.4047 & square hectometer $\left(\mathrm{hm}^{2}\right)$ \\
\hline acre & 0.004047 & square kilometer $\left(\mathrm{km}^{2}\right)$ \\
\hline square mile $\left(\mathrm{mi}^{2}\right)$ & 259.0 & hectare (ha) \\
\hline square mile $\left(\mathrm{mi}^{2}\right)$ & 2.590 & square kilometer $\left(\mathrm{km}^{2}\right)$ \\
\hline \multicolumn{3}{|c|}{ Volume } \\
\hline gallon (gal) & 3.785 & liter $(\mathrm{L})$ \\
\hline gallon (gal) & 0.003785 & cubic meter $\left(\mathrm{m}^{3}\right)$ \\
\hline gallon (gal) & 3.785 & cubic decimeter $\left(\mathrm{dm}^{3}\right)$ \\
\hline cubic foot $\left(\mathrm{ft}^{3}\right)$ & 28.32 & cubic decimeter $\left(\mathrm{dm}^{3}\right)$ \\
\hline cubic foot $\left(\mathrm{ft}^{3}\right)$ & 0.02832 & cubic meter $\left(\mathrm{m}^{3}\right)$ \\
\hline cubic yard $\left(\mathrm{yd}^{3}\right)$ & 0.7646 & cubic meter $\left(\mathrm{m}^{3}\right)$ \\
\hline \multicolumn{3}{|c|}{ Flow rate } \\
\hline foot per second (ft/s) & 0.3048 & meter per second $(\mathrm{m} / \mathrm{s})$ \\
\hline cubic foot per second $\left(\mathrm{ft}^{3} / \mathrm{s}\right)$ & 0.02832 & cubic meter per second $\left(\mathrm{m}^{3} / \mathrm{s}\right)$ \\
\hline \multicolumn{3}{|c|}{ Mass } \\
\hline pound, avoirdupois (lb) & 0.4536 & kilogram $(\mathrm{kg})$ \\
\hline ton, short $(2,000 \mathrm{lb})$ & 0.9072 & megagram $(\mathrm{Mg})$ \\
\hline ton, long $(2,240 \mathrm{lb})$ & 1.016 & megagram $(\mathrm{Mg})$ \\
\hline ton per day (ton/d) & 0.9072 & metric ton per day \\
\hline ton per day (ton/d) & 0.9072 & megagram per day $(\mathrm{Mg} / \mathrm{d})$ \\
\hline ton per day per square mile $\left[(\right.$ ton $\left./ \mathrm{d}) / \mathrm{mi}^{2}\right]$ & 0.3503 & $\begin{array}{l}\text { megagram per day per square } \\
\text { kilometer }\left[(\mathrm{Mg} / \mathrm{d}) / \mathrm{km}^{2}\right]\end{array}$ \\
\hline \multicolumn{3}{|c|}{ Hydraulic gradient } \\
\hline foot per foot (ft/ft) & 0.3048 & meter per meter $(\mathrm{m} / \mathrm{m})$ \\
\hline \multicolumn{3}{|c|}{ Application rate } \\
\hline pounds per acre per year $[(\mathrm{lb} / \mathrm{acre}) / \mathrm{yr}]$ & 1.121 & $\begin{array}{l}\text { kilograms per hectare per year } \\
{[(\mathrm{kg} / \mathrm{ha}) / \mathrm{yr}]}\end{array}$ \\
\hline
\end{tabular}


Temperature in degrees Fahrenheit $\left({ }^{\circ} \mathrm{F}\right)$ may be converted to degrees Celsius $\left({ }^{\circ} \mathrm{C}\right)$ as follows:

${ }^{\circ} \mathrm{C}=\left({ }^{\circ} \mathrm{F}-32\right) / 1.8$

Vertical coordinate information is referenced to the North American Vertical Datum of 1988

(NAVD 88). Horizontal coordinate information is referenced to the North American Datum of 1983 (NAD 83).

Elevation is the distance above a vertical plane defined as the North American Vertical Datum of 1988.

Concentrations of chemical constituents in water are given either in milligrams per liter (mg/L) or micrograms per liter $(\mu \mathrm{g} / \mathrm{L})$. Concentrations of chemical constituents in sediments are given either in milligrams per kilogram $(\mathrm{mg} / \mathrm{kg}$ ) or weight percent $(\mathrm{Wt} \%)$.

Other units used in this report in this report include liter (L), $\mathrm{mL}$ (milliliter), $\mu \mathrm{m}$ (micromho), milligram per kilogram $(\mathrm{mg} / \mathrm{kg})$, microgram per kilogram $(\mu \mathrm{g} / \mathrm{kg})$, and foot per foot $(\mathrm{ft} / \mathrm{ft})$. Use of hectare (ha) as an alternative name for square hectometer $\left(\mathrm{hm}^{2}\right)$ is restricted to the measurement of small land or water areas. Use of liter (L) as a special name for cubic decimeter $\left(\mathrm{dm}^{3}\right)$ is restricted to the measurement of liquids and gases. No prefix other than milli should be used with liter. Metric ton (t) as a name for megagram (Mg) should be restricted to commercial usage, and no prefixes should be used with it. All time information is in Eastern Time with adjustments for Daylight Saving Time.

\section{Abbreviations}

$\begin{array}{ll}\text { AAS } & \text { atomic absorption spectrometry } \\ \text { BFI } & \text { base-flow index } \\ \text { BOS } & \text { Branch of Quality Systems } \\ \text { BTEX } & \text { benzene, toluene, ethylbenzene, and xylenes } \\ \text { CNS } & \text { carbon-nitrogen-sulfur analyzer } \\ \text { CS } & \text { carbon-sulfur analyzer } \\ \text { DCP } & \text { data collection platform } \\ \text { EPA } & \text { U.S. Environmental Protection Agency } \\ \text { ET } & \text { evapotranspiration } \\ \text { gDNA } & \text { genomic deoxyribonucleic acid } \\ \text { NCDENR } & \text { North Carolina Department of Environment and Natural Resources } \\ \text { DWR } & \text { Division of Water Resources } \\ \text { EMC } & \text { Environmental Management Commission } \\ \text { EPT } & \text { Ephemeroptera, Plecoptera, and Trichoptera } \\ \text { EWI } & \text { equal-width increment } \\ \text { ICP-AES } & \text { inductively coupled plasma-atomic emission spectroscopy } \\ \text { LEP } & \text { Laboratory Evaluation Program }\end{array}$




\begin{tabular}{|c|c|}
\hline LRL & laboratory reporting level \\
\hline LT-MDL & long-term method detection level \\
\hline MPN & most probable number \\
\hline MTBE & methyl-tert-butyl ether \\
\hline NCBI & North Carolina Biotic Index \\
\hline NCGS & North Carolina General Statute \\
\hline NED & National Elevation Dataset \\
\hline NIST & National Institute of Standards and Technology \\
\hline NMS & Nutrient Management Strategy \\
\hline NSW & Nutrient Sensitive Waters \\
\hline NWIS & National Water Information System \\
\hline NWQL & National Water Quality Laboratory \\
\hline OWASA & Orange Water and Sewer Authority \\
\hline $\mathrm{PAH}$ & polycyclic aromatic hydrocarbon \\
\hline PVC & polyvinyl chloride \\
\hline $\mathrm{QA} / \mathrm{OC}$ & quality assurance and quality control \\
\hline qPCR & quantitative polymerase chain reaction \\
\hline RPD & relative percent difference \\
\hline SEP & standard error of prediction \\
\hline SRM & standard reference material \\
\hline TKN & total Kjeldahl nitrogen \\
\hline TN & total nitrogen \\
\hline TP & total phosphorus \\
\hline USGS & U.S. Geological Survey \\
\hline WHAT & Web-based hydrograph analysis tool \\
\hline WWTP & wastewater-treatment plant \\
\hline
\end{tabular}




\section{Acknowledgments}

The authors want to thank the Orange Water and Sewer Authority (OWASA) for granting full access to their biosolids land-application and agricultural fields off Orange Grove Road near White Cross, North Carolina, allowing access into their biosolids holding tank facility to collect samples and providing data related to their biosolids land-application rates and class; Lester Ray, farmer and contractor of OWASA, for coordinating with study personnel and adjusting his land-application schedules to accommodate and enable personnel to collect biosolids and pre- and post-application soil samples from the OWASA fields; David McKee, land owner and farmer, for allowing groundwater wells to be installed in his agricultural fields as part of the study and allowing access to his property for collection of groundwater samples from the wells on a quarterly basis during the study; North Carolina Division of Water Resources (DWR, formerly Division of Water Quality) staff for their support and work in installing groundwater wells for the study and collecting quarterly groundwater samples; North Carolina Department of Environment and Natural Resources (NCDENR) Water-Quality Laboratory for conducting analyses of chemical concentrations for metals, total organic carbon, and total suspended solids and autoclaving bottles; Victor Holland and Eric Fleek, Environmental Biologists with NCDENR, for collecting benthic-macroinvertebrate surveys in Collins and Cane Creeks in Orange County, North Carolina, and summarizing the results for this report.

The authors also would like to express sincere gratitude to Sean Egen, Ryan Rasmussen, and Jessica Cain of the U.S. Geological Survey (USGS) South Atlantic Water Science Center, Raleigh Office, for their tireless efforts in sample collection and processing support; Mary Giorgino, USGS, for numerous contributions to the proposal and expert advice throughout the course of the study; Geoffrey Cartano, USGS, for his assistance in installing and initiating the operation of the acoustic Doppler velocimeters at the Collins Creek streamgage; Douglas Smith, USGS, for processing the challenging discharge records for the Collins Creek streamgages and providing detailed and technically sound documentation for the records; Wendi Young, USGS, for her efforts in maintaining scripts to incorporate data transmitted by way of cell modem into the USGS database; William Foreman and Ed Furlong of the USGS

National Water Quality Laboratory for expert advice on an array of analytical issues related to contaminants of emerging concern. 


\title{
Effect of Land-Applied Biosolids on Surface-Water Nutrient Yields and Groundwater Quality in Orange County, North Carolina
}

\author{
By Chad R. Wagner, ' Sharon A. Fitzgerald, ${ }^{1}$ Kristen Bukowski McSwain, ${ }^{1}$ Stephen L. Harden, ${ }^{1}$ \\ Laura N. Gurley, and Shane W. Rogers
}

\section{Abstract}

Land application of municipal wastewater biosolids is the most common method of biosolids management used in North Carolina and the United States. Biosolids have characteristics that may be beneficial to soil and plants. Land application can take advantage of these beneficial qualities, whereas disposal in landfills or incineration poses no beneficial use of the waste. Some independent studies and laboratory analysis, however, have shown that land-applied biosolids can pose a threat to human health and surface-water and groundwater quality. The effect of municipal biosolids applied to agriculture fields is largely unknown in relation to the delivery of nutrients, bacteria, metals, and contaminants of emerging concern to surface-water and groundwater resources. Therefore, the North Carolina Department of Environment and Natural Resources (NCDENR) collaborated with the U.S. Geological Survey (USGS) through the 319 Nonpoint Source Program to better understand the transport of nutrients and bacteria from biosolids application fields to groundwater and surface water and to provide a scientific basis for evaluating the effectiveness of the current regulations.

The USGS conducted a paired agricultural watershed study in the Collins Creek and Cane Creek Reservoir watersheds in Orange County, North Carolina. Field activities were conducted from March 2011 through May 2013 at two field study sites, including biosolids field application sites owned by Orange County Water and Sewer Authority (OWASA) in the Collins Creek watershed and a background study site in the Cane Creek watershed that has no fields receiving biosolids applications. Samples of biosolids source material and soil were collected from the land-application fields for laboratory analyses. Soil

\footnotetext{
${ }^{1}$ U.S. Geological Survey.

${ }^{2}$ Clarkson University.
}

samples were also collected from a background agricultural field in the Cane Creek watershed that has never received land-applied municipal biosolids. Shallow groundwater samples were collected quarterly from new monitoring wells installed by NCDENR along the edge of the biosolids land-application fields and a background agricultural field for laboratory analyses. Two surface-water monitoring sites were established on Collins Creek to compute continuous streamflow and collect discrete baseflow and stormwater runoff water-quality data upstream and downstream from the biosolids land-application fields. Surface waterquality samples were also collected for baseflow and stormwater runoff conditions at an existing USGS streamgage on Cane Creek to monitor water-quality conditions in the background study watershed. The study primarily focused on nutrients and bacteria; however, data for field properties and water-quality constituents, including metals, major ions, and contaminants of emerging concern (household-, industrial-, and agricultural-use compounds, pharmaceutical compounds, hormones, and antibiotics) also were collected and used in the analyses.

There were no exceedances of the 10 elements with designated U.S. Environmental Protection Agency (EPA) ceiling concentrations for land-applied biosolids in any of the biosolids samples. Treatment processes and storage techniques used by OWASA are effective in eliminating Escherichia coli and fecal coliform bacteria from biosolids. Copper, molybdenum, total Kjeldahl nitrogen, and total phosphorus were elevated in the soil from biosolids land-application fields relative to the background field. The relative richness of these constituents in the biosolids land-application fields is consistent with biosolids being the source of the elevated concentrations given the relatively high concentrations of these constituents in the biosolids samples that were collected.

Shallow groundwater in the transitional zone wells, which were located adjacent to and topographically downgradient from all the biosolids land-application fields, were found to be statistically different and had higher nitrate concentrations (medians greater than 12 milligrams per liter) than all the other wells sampled as part of the study. Surface-water nutrient concentrations and yields, primarily nitrate, were higher at the 
monitoring site on Collins Creek downstream from the biosolids land-application fields than the other study sites that drained watersheds without biosolids land application. The largest differences in concentrations between sites were measured at baseflow conditions, which indicate that the main cause of these differences, particularly between Cane Creek and the Collins Creek site downstream from the OWASA application fields, is related to nitrate contribution from the shallow groundwater.

Contaminants of emerging concern were detected in approximately 40 percent of the laboratory analyses of the biosolids samples and more frequently in soil samples from the biosolids land-application fields (approximately 40 percent of laboratory analyses) relative to the soil samples from the background field (approximately 12 percent of laboratory analyses). However, contaminants of emerging concern detected in the laboratory analysis for this study do not appear to be good indicators of human-waste contaminants derived from landapplied biosolids in groundwater or surface-water because the number of detections and concentrations at the background wells and surface-water monitoring sites are similar to or higher than those at wells and monitoring sites adjacent to or downstream from the biosolids land-application fields.

The data, analysis, and conclusions associated with this study can be used by regulatory agencies, resource managers, and wastewater-treatment operators to (1) better understand the quantity and characteristics of nutrients, bacteria, metals, and contaminants of emerging concern that are transported away from biosolids land-application fields to surface water and groundwater under current regulations for the purposes of establishing effective total maximum daily loads (TMDLs) and restoring impaired water resources, (2) assess how well existing regulations protect waters of the State and potentially recommend effective changes to regulations or land-application procedures, and (3) establish a framework for developing guidance on effective techniques for monitoring and regulatory enforcement of permitted biosolids land-application fields.

\section{Introduction}

Biosolids are defined as any solid, semi-solid, or liquid waste, other than raw effluent or residues from agricultural products and processing, generated from a wastewater-treatment facility, water-supply treatment facility, or air pollution control facility permitted under the authority of the North Carolina Environmental Management Commission (EMC). Depending on the level of treatment that the biosolids receive, the biosolids may be applied to land for fertilizer or disposed of in a surface disposal unit (such as a land fill or incineration). As of December 2009, a total of 260 facilities in North Carolina were permitted to apply biosolids to land and only 15 facilities were permitted for surface disposal.

Land application of municipal wastewater biosolids is the most common method of biosolids management used in North Carolina and the United States (National Research Council of the
National Academy of Sciences, 2002). Biosolids have characteristics that may be beneficial to soil and plants. Land application can take advantage of these beneficial qualities, whereas disposal in landfills or incineration poses no beneficial use of the waste (National Research Council of the National Academy of Sciences, 2002; Lu and others, 2012). For these reasons, the State of North Carolina and the U.S. Environmental Protection Agency (EPA) consider controlled land application a "beneficial use" of biosolids. However, some independent studies and laboratory analyses (National Research Council of the National Academy of Sciences, 2002; Rudo, 2005; U.S. Environmental Protection Agency, 2009) have shown that biosolids can pose a threat to human health as well as surface-water and groundwater quality. Hence, biosolids are defined as waste under North Carolina General Statute (NCGS) 142-213, and any system that collects, treats, or disposes of waste cannot be constructed or operated without a permit (NCGS 143-215.1(a)). The statute (NCGS 143-215.1(a)) authorizes the EMC and the North Carolina Department of Environment and Natural Resources (NCDENR) to develop and implement State regulations and to issue permits for the generation and disposal of residual biosolids; however, only NCDENR's Division of Water Resources (DWR) carries out these functions. The North Carolina rules (15A NCAC 02T.1109) for biosolids management meet or exceed the Title 40 Code of Federal Regulations part 503 (40 CFR 503) standards for the use or disposal of sewage sludge.

The permitting request and approval process implemented by DWR is designed to provide relevant information to concerned parties before, during, and after the application of biosolids in an attempt to assure that land applications of biosolids are managed safely and effectively. The DWR conducts reviews of all permit applications, performs site visits to proposed application fields to verify site conditions, and works with county managers and health departments to address local concerns with proposed biosolids land-application activities. Permit holders are required to provide DWR with annual reports that summarize the past year's activities and document that biosolids quality and nutrient management requirements were met. Permit holders also are responsible for meeting the requirements of their permit and for reporting any permit violations. Monitoring and enforcement of permit requirements is challenging and relies primarily on self-reporting of permittees (supplier of the biosolids) and citizen complaints. There are no consistent guidelines on monitoring groundwater and surface water at biosolids land-applications sites that can identify potential contamination problems before they arise. The monitoring of permit requirements often are the result of reported complaints or evidence of impacts to waters of the State after contamination has occurred. A better understanding of the quantity and characteristics of nutrients, bacteria, metals, and contaminants of emerging concern that are transported from biosolids fields to groundwater and surface-water resources would provide the framework for developing guidance on effective techniques for monitoring and regulatory enforcement of permitted biosolids land-application sites.

Pollutant limits termed ceiling concentrations and cumulative pollutant loading rates for land-applied biosolids have 
been established for 10 metals (arsenic, cadmium, chromium, copper, lead, mercury, molybdenum, nickel, selenium, and zinc) identified by the EPA as being of particular concern (U.S. Environmental Protection Agency, 1994a, 1995). Pathogen reduction requirements for biosolids have been established in North Carolina that meet the Federal requirements of 40 CFR 503. Permit requirements also are in place to address nutrient management on land receiving biosolids. These requirements stipulate that when applied to agricultural fields, the biosolids must be applied at agronomic rates that are based on the realistic yield expectations for crops related to the local soil classification. The operational and management practice requirements further specify under what conditions biosolids can be land applied and establish time frames for restricted use of the fields after biosolids applications. Although these requirements are in place, there is limited scientific information available to quantify the actual delivery of pollutants, such as nutrients, bacteria, metals, and contaminants of emerging concern, from biosolids application fields to groundwater and surface water and to determine if the current requirements are protective of water resources and human health. As of September 2009, the DWR permitted approximately 5,145 fields (107,200 acres) in North Carolina for the land application of biosolids (North Carolina Department of Environment and Natural Resources, Division of Water Resources, n.d.[c]). The lack of data from existing permitted biosolids application sites makes it difficult for DWR to assess how well the existing regulations protect the waters of the State or to recommend effective changes to regulations or procedures. The task of assessing the effect of biosolids application is complicated by the difficulty in determining the source(s) of common pollutants, such as nitrate and bacteria, in groundwater and surface waters. Therefore, to better understand the effect of land-applied municipal biosolids on nutrient and bacteria delivery to surface-water and groundwater resources under current regulations, a study was conducted to quantify the nonpoint source concentrations and loadings of nutrients, metals, and bacteria from representative agricultural fields with and without land-applied municipal biosolids.

\section{Purpose and Scope}

The purpose of this report is to characterize the transport of nutrients, bacteria, metals with EPA ceiling concentrations, and contaminants of emerging concern from biosolids landapplication fields to groundwater and surface water. Specifically, this report (1) documents differences in chemistry of soil from agricultural fields with and without land-applied biosolids and the variability in chemistry of the applied biosolids; (2) presents a comparison of constituent concentrations in shallow groundwater under agricultural fields with and without land-applied biosolids; (3) presents a comparison of stormwater runoff and baseflow concentrations and loads of selected constituents at surface-water sites draining watersheds with and without biosolids landapplication fields; and (4) documents a preliminary evaluation of contaminants of emerging concern as potential indicators of constituents derived from wastewater-treatment plant biosolids in surface water and groundwater.

This collaborative study between the DWR (formerly named the Division of Water Quality) and the U.S. Geological Survey (USGS) was conducted in two adjacent agricultural watersheds - Collins Creek and Cane Creek - in Orange County, North Carolina (fig. 1). Most field data for the paired watershed study sites were collected over a 2-year, 4-month period, beginning in March 2011 and ending in June 2013. The Collins Creek watershed contains multiple biosolids land-application fields owned and operated by the Orange County Water and Sewer Authority (OWASA), and the Cane Creek watershed is considered the background setting and contains no fields receiving land application of biosolids.

The scope of work included the installation of a rain gage for monitoring continuous precipitation and six groundwater wells for monitoring water levels and collecting shallow groundwater samples (table 1). In addition, two surface-water monitoring sites were established on Collins Creek to collect streamflow and water-quality data upstream and downstream from OWASA's biosolids land-application fields, and surface water-quality samples were collected at an existing USGS streamgage on Cane Creek upstream from Cane Creek Reservoir to monitor water-quality conditions in the background watershed (fig. 1; table 1). Samples of biosolids source material, soil, groundwater, and surface water were collected for laboratory analyses from the Collins Creek watershed to examine potential effects resulting from biosolids land application. Samples of soil, groundwater, and surface water were collected for laboratory analyses from the Cane Creek watershed to provide baseline information on background agricultural conditions to aid in the evaluation of results obtained at the Collins Creek biosolids study site. Both analytical and streamflow data were used in developing model estimates of surface-water loads and yields for nutrients at each study site to examine potential relations in stream loadings and yields at sites with and without biosolids applications.

Samples of biosolids, soils, groundwater, and surface water were analyzed primarily for nutrients, major ions, metals, and bacteria. In addition, selected samples were analyzed for contaminants of emerging concern (including household-, industrial-, and agricultural-use compounds, pharmaceutical compounds, hormones, and antibiotics), hydrocarbons, and bacteria-related genetic biomarkers. This report primarily focuses on nutrients and bacteria because these are priority constituents for the DWR Nonpoint Source Management Program and because there is a Total Maximum Daily Load (TMDL) requirement for nutrients in the study area. Data for other water-quality constituents, including field properties, metals, major ions, contaminants of emerging concern, hydrocarbons and genetic biomarkers, are also presented in the report to help characterize the potential effect of land-applied biosolids on groundwater and surface water. Finally, a benthic macroinvertebrate survey was conducted in May 2012 at three sites in the Cane Creek and Collins Creek watersheds to document differences in ecology and habitat that could be related to land-application of biosolids. 


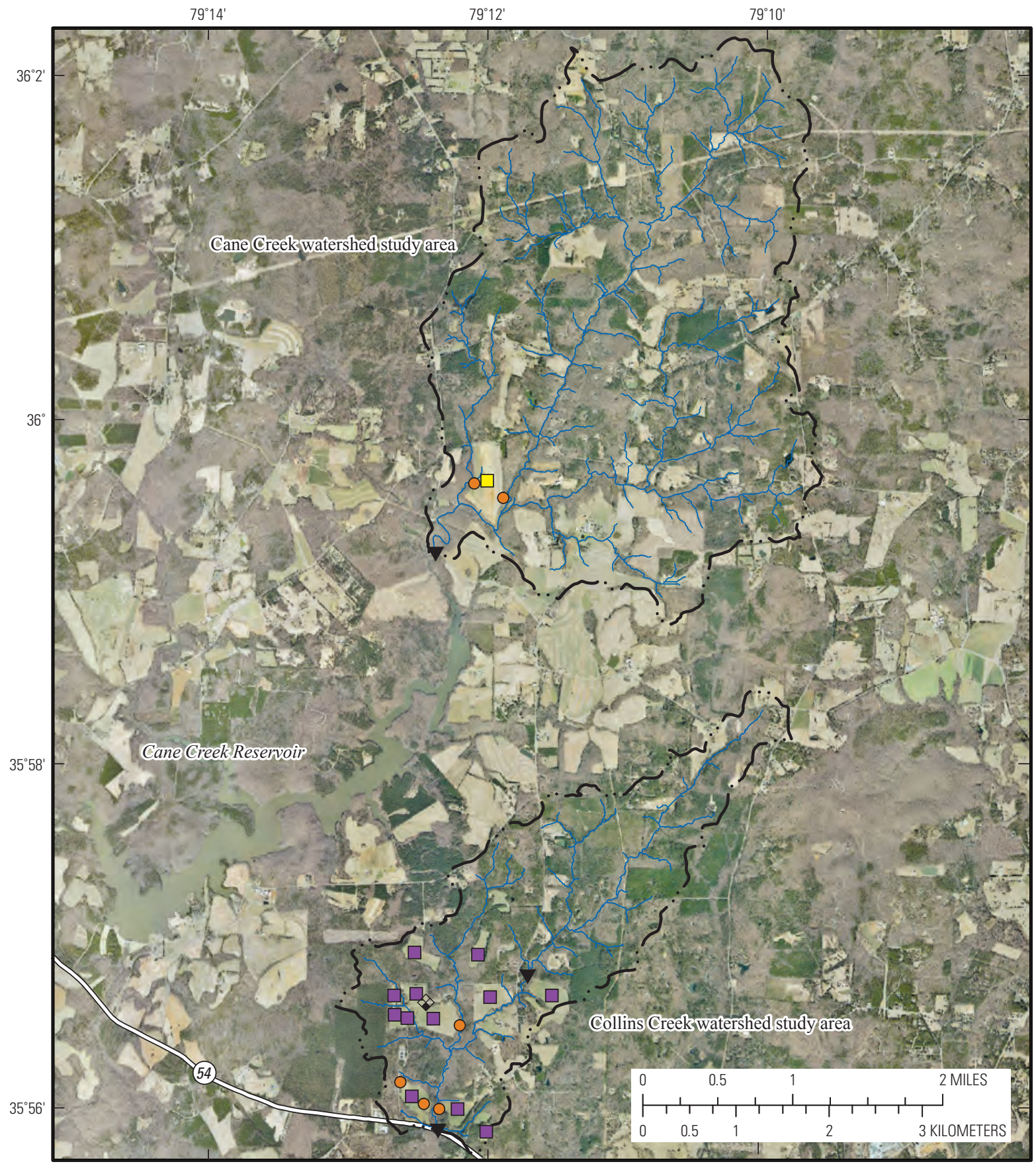

Base map imagery from City of Durham and NC 911 Board (6-in resolution) Elevation-derived streams circa 1:5,000 scale, U.S. Geological Survey Basin boundaries from the 1:24,000 scale National Hydrography Dataset, U.S. Geological Survey, State boundaries from the 1:100,000 scale TIGER/Line dataset, U.S. Census Bureau Projection: North Carolina State Plane (feet), NAD 1983

\begin{tabular}{ll}
\multicolumn{1}{c}{ EXPLANATION } \\
Raingage \\
Streamgage and water-quality monitoring sites \\
Groundwater monitoring wells \\
Agricultural fields included in study \\
$\square \quad$ Receiving land-applied biosolids \\
$\square \quad$ Never receiving land-applied biosolids
\end{tabular}

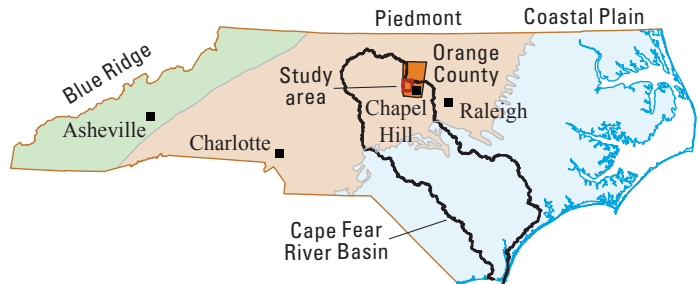

Location of study area, Orange County, selected cities, physiographic provinces,

and the Cape Fear River Basin in North Carolina

Figure 1. Location of the Cane Creek and Collins Creek watershed study area in the Cape Fear River Basin, Orange County, North Carolina. 
Table 1. Data-collection network for the Collins Creek and Cane Creek study watersheds in Orange County, North Carolina.

[ID, identification; USGS, U.S. Geological Survey; NC, North Carolina; HWY, highway; SR, secondary road]

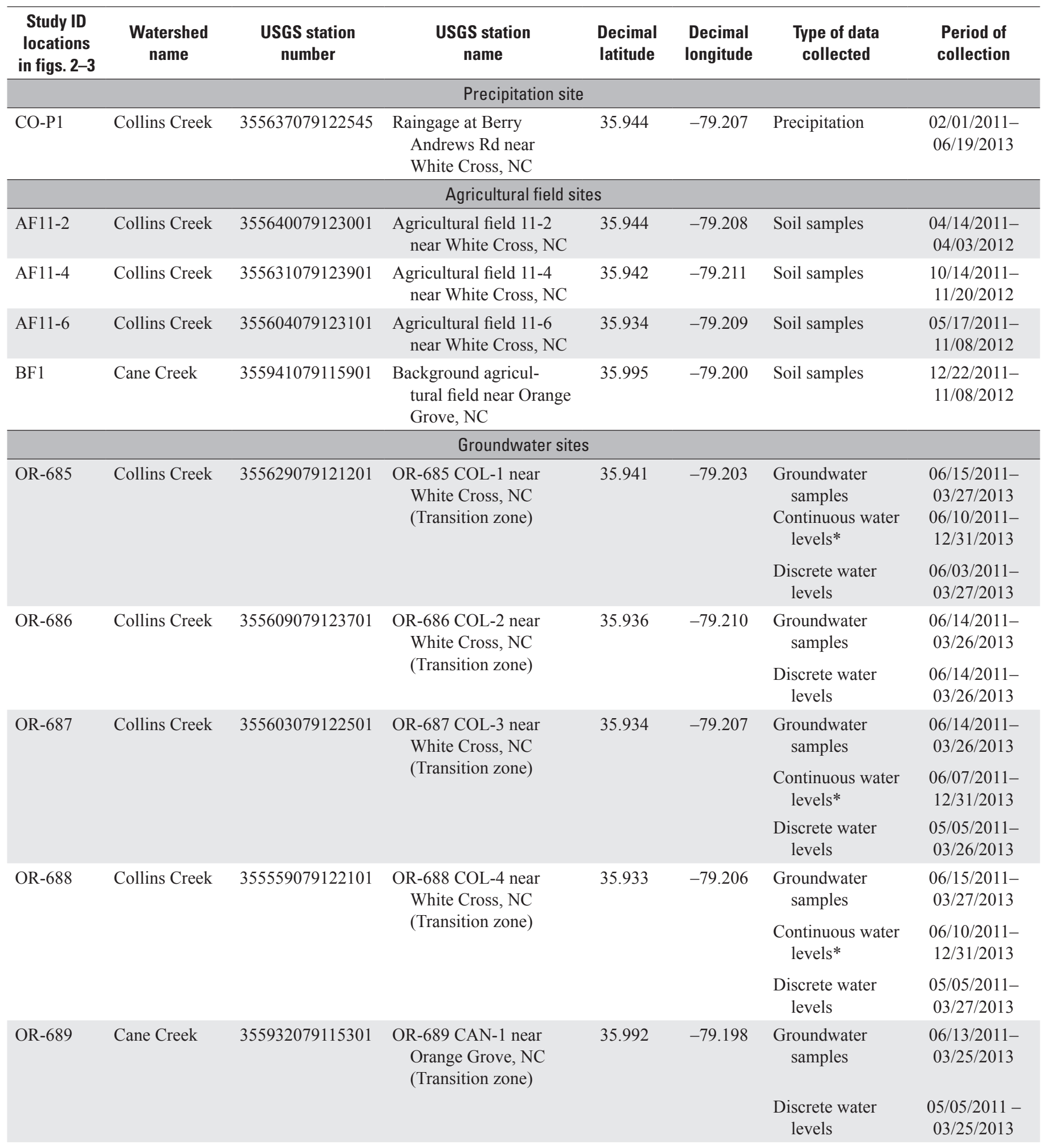


Table 1. Data-collection network for the Collins Creek and Cane Creek study watersheds in Orange County, North Carolina.-Continued [ID, identification; USGS, U.S. Geological Survey; NC, North Carolina; HWY, highway; SR, secondary road]

\begin{tabular}{|c|c|c|c|c|c|c|c|}
\hline $\begin{array}{c}\text { Study ID } \\
\text { locations } \\
\text { in figs. 2-3 }\end{array}$ & $\begin{array}{l}\text { Watershed } \\
\text { name }\end{array}$ & $\begin{array}{l}\text { USGS station } \\
\text { number }\end{array}$ & $\begin{array}{l}\text { USGS station } \\
\text { name }\end{array}$ & $\begin{array}{l}\text { Decimal } \\
\text { latitude }\end{array}$ & $\begin{array}{l}\text { Decimal } \\
\text { longitude }\end{array}$ & $\begin{array}{l}\text { Type of data } \\
\text { collected }\end{array}$ & $\begin{array}{l}\text { Period of } \\
\text { collection }\end{array}$ \\
\hline \multirow[t]{2}{*}{ OR-690 } & Cane Creek & 355938079120601 & $\begin{array}{c}\text { OR-690 CAN-2 near } \\
\text { Orange Grove, NC } \\
\text { (Transition zone) }\end{array}$ & 35.994 & -79.202 & $\begin{array}{l}\text { Groundwater } \\
\text { samples }\end{array}$ & $\begin{array}{c}06 / 13 / 2011- \\
03 / 25 / 2013\end{array}$ \\
\hline & & & & & & $\begin{array}{l}\text { Discrete water } \\
\text { levels }\end{array}$ & $\begin{array}{c}05 / 05 / 2011- \\
03 / 25 / 2013\end{array}$ \\
\hline \multirow[t]{2}{*}{ CO-SW1 } & \multirow[t]{2}{*}{ Collins Creek } & \multirow[t]{2}{*}{0209691590} & \multirow{2}{*}{$\begin{array}{l}\text { Collins Creek above } \\
\text { SR } 1006 \text { near White } \\
\text { Cross, NC }\end{array}$} & \multirow[t]{2}{*}{35.946} & \multirow[t]{2}{*}{-79.195} & $\begin{array}{l}\text { Surface-water } \\
\text { samples }\end{array}$ & $\begin{array}{c}03 / 01 / 2011- \\
05 / 31 / 2013\end{array}$ \\
\hline & & & & & & $\begin{array}{l}\text { Stream stage and } \\
\text { discharge }\end{array}$ & $\begin{array}{c}03 / 01 / 2011- \\
05 / 31 / 2013\end{array}$ \\
\hline CO-SW4 & Collins Creek & 0209691604 & $\begin{array}{l}\text { Collins Creek midstream } \\
\text { below SR } 1006 \text { White } \\
\text { Cross, NC }\end{array}$ & 35.939 & -79.204 & $\begin{array}{l}\text { Surface-water } \\
\text { samples }\end{array}$ & $\begin{array}{c}12 / 20 / 10 \text { and } \\
11 / 29 / 11\end{array}$ \\
\hline \multirow[t]{2}{*}{ CO-SW5 } & \multirow[t]{2}{*}{ Collins Creek } & \multirow[t]{2}{*}{0209691611} & \multirow{2}{*}{$\begin{array}{l}\text { Collins Creek at HWY } \\
54 \text { near White Cross, } \\
\text { NC }\end{array}$} & \multirow[t]{2}{*}{35.932} & \multirow[t]{2}{*}{-79.206} & $\begin{array}{l}\text { Surface-water } \\
\text { samples }\end{array}$ & $\begin{array}{c}03 / 01 / 2011- \\
05 / 31 / 2013\end{array}$ \\
\hline & & & & & & $\begin{array}{l}\text { Stream stage and } \\
\text { discharge }\end{array}$ & $\begin{array}{c}03 / 01 / 2011- \\
05 / 31 / 2013\end{array}$ \\
\hline CA-SW1 & Cane Creek & 02096846 & $\begin{array}{l}\text { Cane Creek near Orange } \\
\text { Grove, NC }\end{array}$ & 35.987 & -79.206 & $\begin{array}{l}\text { Surface-water } \\
\text { samples }\end{array}$ & $\begin{array}{c}10 / 25 / 1988- \\
\text { present }\end{array}$ \\
\hline
\end{tabular}

*Continuous water-level data are provided by the North Carolina Department of Environment and Natural Resources, Division of Water Resources, as one data point per day. 


\section{Description of the Study Area}

The Collins Creek and Cane Creek watershed study sites are located in Orange County, North Carolina, in the Piedmont Physiographic Province (fig. 1; table 1). Both Collins Creek and Cane Creek drain to the Haw River, a major tributary of Jordan Lake in the Cape Fear River Basin. Surface waters in the stream segments included in the study for Collins Creek and Cane Creek have DWRassigned primary-use classifications of WS-V and WS-II, respectively, which are protected as sources of water supply (North Carolina Department of Environment and Natural Resources, Division of Water Resources, n.d.[b]). These creeks also have an assigned supplemental classification of Nutrient Sensitive Waters (NSW), which identifies surface-water bodies that are in need of additional nutrient management. In response to water-quality concerns related to overenrichment of nutrients in Jordan Lake, the EMC adopted a Nutrient Management Strategy (NMS) in 2009 to restore and protect water quality in Jordan Lake (North Carolina Department of Environment and Natural Resources, Division of Water Resources, n.d.[a]). The NMS consists of a comprehensive set of rules for reducing stream inputs of nitrogen and phosphorus from point and nonpoint sources within the Jordan Lake watershed, including Collins and Cane Creeks.

Characterization of land-cover information for the surface-water monitoring sites installed upstream and downstream from the OWASA biosolids land-application fields on Collins Creek (CO-SW1 and CO-SW5, respectively; fig. 2) and the surface-water monitoring site on Cane Creek (CA-SW1, fig. 3) was based on data obtained using the USGS StreamStats application developed for North Carolina (http://water.usgs.gov/osw/streamstats/north_carolina.html, accessed October 7, 2014). Land cover within the contributing drainage areas of the surface-water sites is similar with no major differences noted (table 2). The contributing land areas upstream from the surface-water sites are largely undeveloped, containing minimal amounts (about 5 percent) of developed lands, and housing densities are sparse. The houses in both watersheds utilize septic wastewater systems. Forested land accounts for the largest fraction (about 68 to 73 percent) of the overall land areas within the stream drainages and provides habitat to support large populations of wildlife, such as deer, fox, raccoon, and turkey. Pasture and crop lands are the next highest land-cover category, accounting for about 17 to 20 percent of the land within the stream drainages, supporting primarily cattle (beef and dairy), hay, corn, and soybean production.

The Collins Creek and Cane Creek study sites also have similar soil types. Detailed information on the types of soils present at the Collins Creek and Cane Creek study sites can be accessed through the U.S. Department of Agriculture Web Soil Survey (Soil Survey Staff, Natural Resources Conservation Service, n.d.). The soil types of the biosolids application fields at the Collins Creek study site are predominantly classified as silt loam (Herndon, Lignum, and Georgeville) with $0-10$ percent slopes, and the soil types of the background field at the Cane Creek study site are predominantly classified as silt loam (Georgeville and Herndon) with 2-10 percent slopes.

The geology underlying Orange County is a complex combination of folded, fractured, and intruded igneous and metaigneous (extrusive-eruptive) bedrock (Cunningham and Daniel, 2001). At the Collins Creek and Cane Creek study sites, the bedrock comprises primarily felsic tuffs, dacitic lavas, and tuffaceous sandstones, mudstones, and siltstones (Bradley and Stoddard, 2008). The bedrock generally is overlain by a weathered regolith composed of soil residuum, saprolite, alluvium, and colluvium. The alluvium material in the regolith is found primarily near the banks of creeks and tributaries. Groundwater flow consists of an interconnected three-component system in which the regolith and transition zone (between the regolith and bedrock) provides storage for the underlying bedrock. The groundwater system in the study areas have two primary components: the surficial aquifer composed of the shallow weathered regolith and transition zone, and the fractured bedrock aquifer composed of the deeper unweathered fractured bedrock. Only groundwater in the surficial aquifer was investigated at the Collins Creek and Cane Creek study sites. 


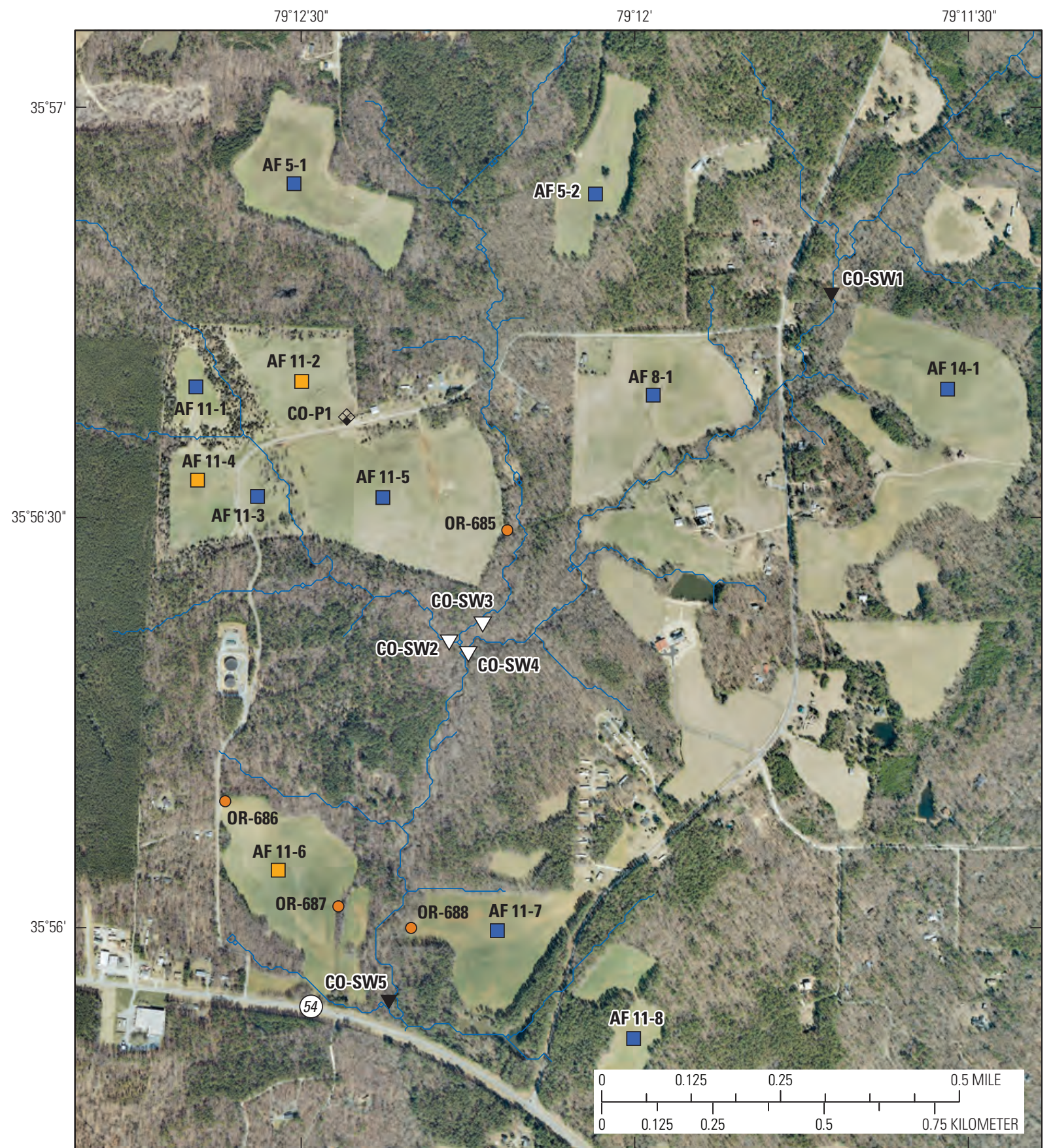

Base map imagery from City of Durham and NC 911 Board (6-in resolution) Elevation-derived streams circa 1:5,000 scale, U.S. Geological Survey Basin boundaries from the 1:24,000 scale National Hydrography Dataset,

U.S. Geological Survey, State boundaries from the 1:100,000 scale TIGER/Line dataset,

U.S. Census Bureau, Projection: North Carolina State Plane (feet), NAD 1983
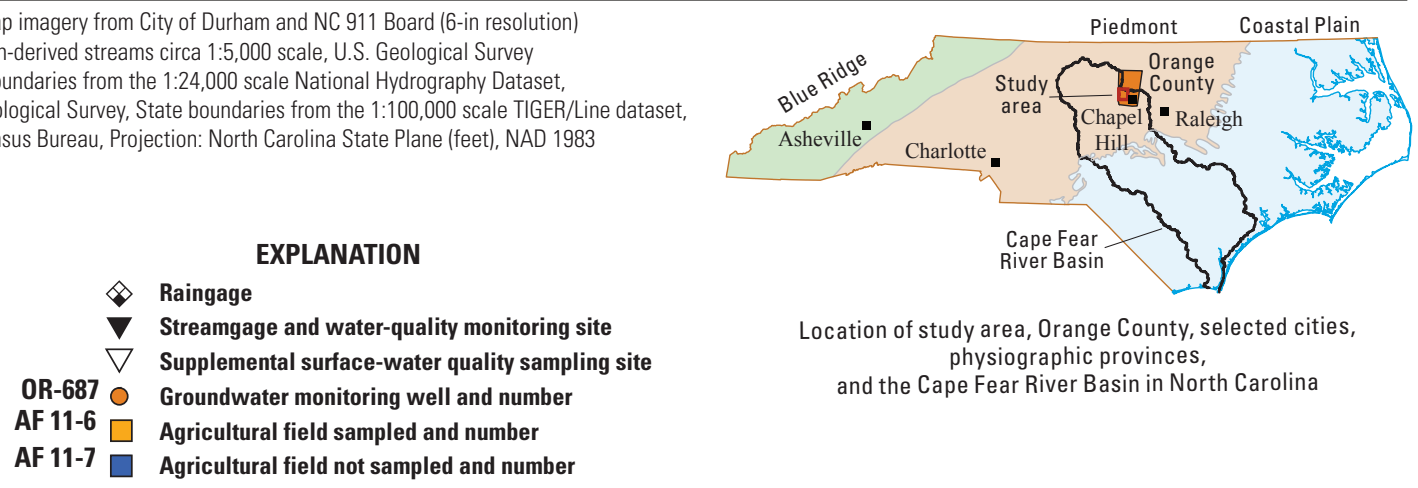

Location of study area, Orange County, selected cities, physiographic provinces,

and the Cape Fear River Basin in North Carolina

Figure 2. Locations of biosolids land-application fields and associated groundwater and surface-water monitoring sites in the Collins Creek watershed in Orange County, North Carolina. 


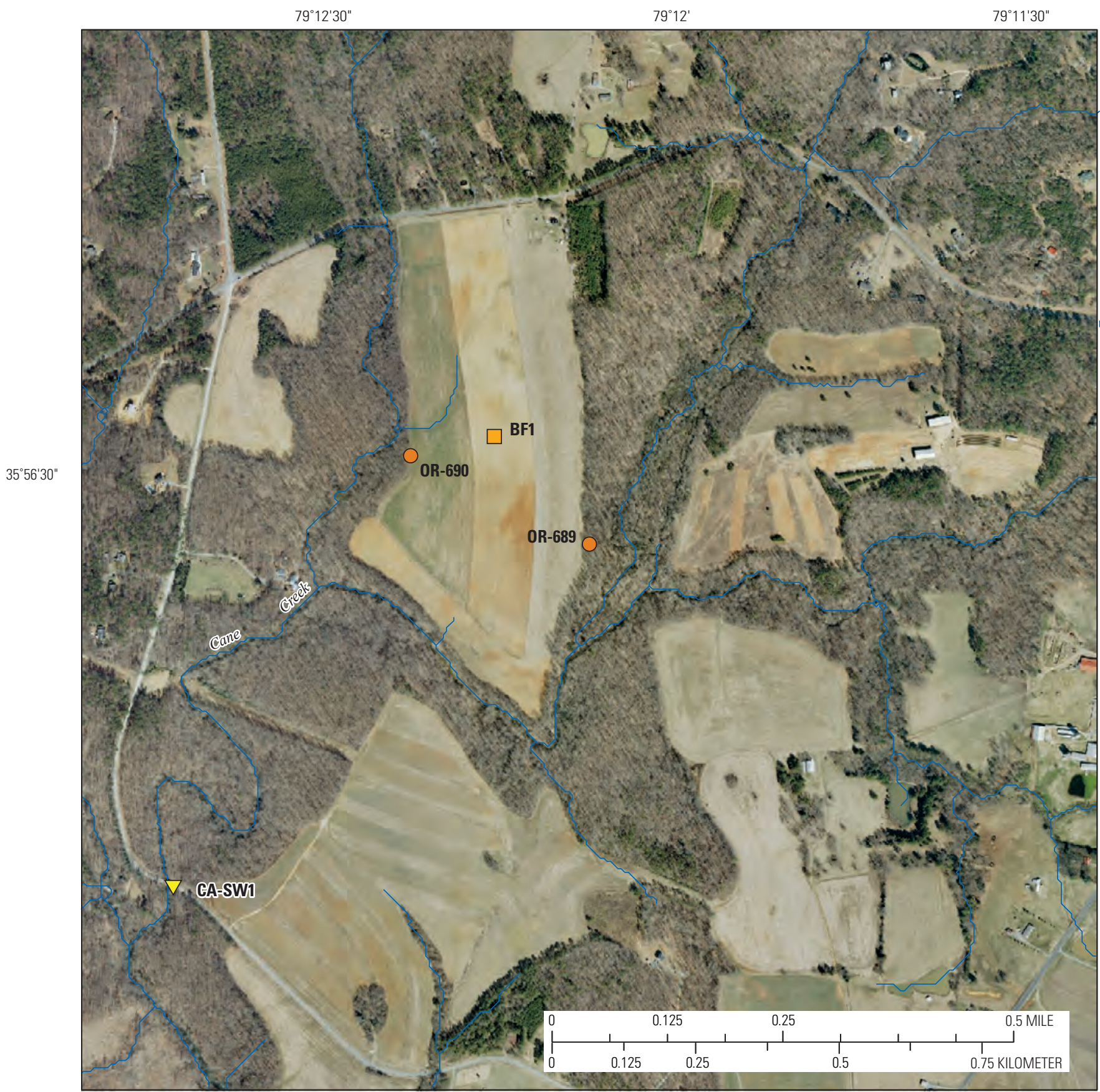

Base map imagery from City of Durham and NC 911 Board (6-in resolution) Elevation-derived streams circa 1:5,000 scale, U.S. Geological Survey Basin boundaries from the 1:24,000 scale National Hydrography Dataset,

U.S. Geological Survey, State boundaries from the 1:100,000 scale TIGER/Line dataset, U.S. Census Bureau, Projection: North Carolina State Plane (feet), NAD 1983

\section{EXPLANATION}

CA-SW1 $\nabla$ Streamgage and water-quality monitoring site and number

OR-689 Groundwater monitoring well and number BF1 $\square$ Agricultural location and number

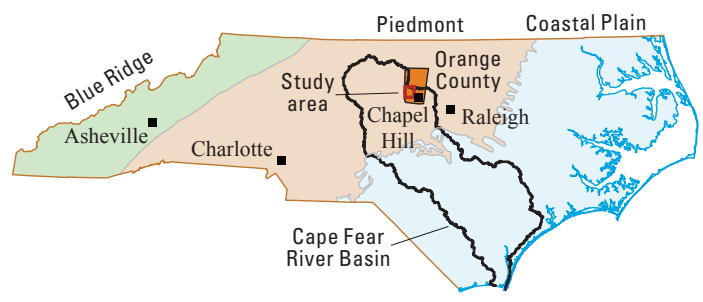

Location of study area, Orange County, selected cities, physiographic provinces,

and the Cape Fear River Basin in North Carolina

Figure 3. Locations of the background agricultural field and associated groundwater and surface-water monitoring sites in the Cane Creek watershed in Orange County, North Carolina. 
Table 2. Land-cover information for Collins Creek and Cane Creek surface-water monitoring sites in Orange County, North Carolina.

[ID, identification; USGS, U.S. Geological Survey; $\mathrm{mi}^{2}$, square mile; NC, North Carolina; HWY, highway; SR, secondary road]

\begin{tabular}{|c|c|c|c|c|c|c|c|c|c|}
\hline \multirow{2}{*}{$\begin{array}{l}\text { Study ID } \\
\text { location, } \\
\text { (figs. 2 } \\
\text { and 3) }\end{array}$} & \multirow[b]{2}{*}{$\begin{array}{l}\text { USGS station } \\
\text { name }\end{array}$} & \multirow{2}{*}{$\begin{array}{c}\text { Basin } \\
\text { drainage } \\
\text { area } \\
\left(\mathrm{mi}^{2}\right)\end{array}$} & \multicolumn{7}{|c|}{ Land-cover category (percent) } \\
\hline & & & Water & Wetlands & Barren & Developed & $\begin{array}{l}\text { Shrubs } \\
\text { and } \\
\text { grassland }\end{array}$ & $\begin{array}{l}\text { Pasture } \\
\text { and crops }\end{array}$ & Forested \\
\hline CO-SW1 & $\begin{array}{l}\text { Collins Creek above } \\
\text { SR } 1006 \text { near } \\
\text { White Cross, NC }\end{array}$ & 1.7 & 0.0 & 0.1 & 0.0 & 5.6 & 8.3 & 17.3 & 68.7 \\
\hline CO-SW5 & $\begin{array}{l}\text { Collins Creek at } \\
\text { HWY } 54 \text { near } \\
\text { White Cross, NC }\end{array}$ & 3.2 & 0.1 & 0.5 & 0.0 & 5.4 & 5.4 & 20.5 & 68.1 \\
\hline CA-SW1 & $\begin{array}{l}\text { Cane Creek near } \\
\text { Orange Grove, NC }\end{array}$ & 7.5 & 0.2 & 0.1 & 0.3 & 4.5 & 5.0 & 17.2 & 72.8 \\
\hline
\end{tabular}

\section{Methods of Data Compilation and Analyses}

The collection of hydrologic and analytical data at the study sites began in March 2011 and was completed in June 2013. This section provides a discussion of the methods used for measuring precipitation, water levels, and stream discharge, collecting and analyzing field samples, and determining stream constituent loads at the study sites. Statistical methods used for evaluating the environmental datasets also are presented.

\section{Description of Study Sites and Field Data- Collection Activities}

Environmental data collected from the Collins Creek watershed and the Cane Creek background watershed were used to evaluate potential differences in the quality of soil, groundwater, and surface water resulting from land applications of municipal biosolids. The environmental data-collection network consisted of 1 precipitation gage, 4 agricultural field sites, 6 groundwater wells, 3 surface-water quality and streamflow monitoring sites, and 3 additional surface-water sites on Collins Creek from which only a few discrete water-quality samples were collected (table 1; figs. 2 and 3). All precipitation, groundwater-level, and streamflow data, and analytical results of the water-quality sampling for all study sites are available online from the USGS National Water Information System (NWIS) web site (http://waterdata.usgs.gov/nc/nwis/, accessed October 8, 2014) and in USGS Annual Water Data Reports (http://wdr.water.usgs.gov/, accessed October 8, 2014).

\section{Precipitation}

A rain gage was installed at site $\mathrm{CO}-\mathrm{P} 1$ at the Collins Creek biosolids study site (table 1; fig. 2) to monitor precipitation during the study and to facilitate the collection of surface-water samples during and after storm events. Precipitation data were measured using an ISCO 674 tipping-bucket rain gage at a resolution of 0.01 inch per tip. The rain gage was connected to a Sutron 8200 data collection platform (DCP), which recorded precipitation data at 15-minute intervals. Rainfall data were transmitted by way of satellite telemetry to the USGS NWIS database for subsequent online presentation (http://waterdata.usgs.gov/nc/nwis).

The precipitation data were collected and processed in accordance with USGS guidelines (U.S. Geological Survey, 2005 ) to ensure proper quality-assurance procedures were followed. Calibration checks were conducted semi-annually on the rain gage to ensure the accuracy of recorded data. All recorded data were examined and any data found to be affected by periods of frozen precipitation or equipment malfunctions were removed from the NWIS database. Daily total precipitation data from March 2011 through June 2013 were retrieved for site CO-P1 (table 1; fig. 2) through the NWIS database for use in examining relations between hydrologic conditions and the analytical results of soil, groundwater, and surface-water samples collected at the Collins Creek biosolids study site and Cane Creek background site. The data record includes a gap from April 1 to April 19, 2012, when precipitation was not measured because of an equipment malfunction. 


\section{Biosolids and Soils Samples}

Four agricultural fields were used (table 1; figs. 2 and 3) for collecting samples of biosolids and (or) soils for laboratory analyses. The OWASA biosolids land-application area in the Collins Creek watershed is composed of 12 individual agricultural fields that periodically received land applications of municipal biosolids during the study period (fig. 2). The applied biosolids serve as a source of nutrients to the crops grown in these fields, consisting primarily of cover crops although select fields (such as AF 11-6, fig. 2) also are used for growing row crops. Several of the application fields (AF 8-1 and AF 11-1 through AF 11-5) at this study site are used as pasture for beef cattle.

Samples for laboratory analysis of biosolids and soils were collected from 3 of the 12 application fields (AF 11-2, AF 11-4, and AF 11-6) at the Collins Creek biosolids study site primarily to document the amounts of nutrients, metals, and fecal-indicator bacteria found in both the applied biosolids material and the soils receiving applications of the biosolids. Selected samples also were analyzed to document the presence of contaminants of emerging concern, hydrocarbons, and specific bacteria-related genetic biomarkers in the biosolids and soils. Three rounds of sampling were conducted for each of these application fields. Each sampling round included a soil sample collected before and after the application of biosolids and a sample of the biosolids material applied to the field. The residual biosolids materials applied to the fields consist of biosolids that are derived from the Orange County wastewater-treatment plant (WWTP), which uses a process of primary clarification (settling), secondary treatment (waste digestion through microorganisms in aeration basins), secondary clarification (settling), filtration (sand filters), and disinfection with ultraviolet light. Solids that are removed from the primary and secondary clarification processes are thickened and pumped into large anaerobic digesters in which microorganisms break down biogradable material in the absence of free oxygen under high temperatures for at least 30 days (http://www.owasa.org/ wastewater-management accessed on September 9, 2014). These treated solids are referred to as biosolids, for which two classes are produced by OWASA, Class A and B, determined from the level of pathogens (Salmonella sp., enteric viruses, and viable helminth ova) present in the material when applied (U.S. Environmental Protection Agency, 1994a). Class A biosolids have no detectable levels of these pathogens, whereas Class B has detectable levels that are not a threat to public health and the environment given adequate protective actions. Treated biosolids from the WWTP are stored in liquid form (containing about 1 to 3 percent solids) in large holding tanks located at the Collins Creek biosolids study site until ready for disposal in the application fields. When ready for application, the liquid biosolids material is transferred to a portable tank that is fitted with a spray nozzle and towed by a tractor, and the biosolids are spray applied to the application fields.
The samples of the biosolids material collected at the Collins Creek biosolids study site are regarded as grab samples in that the samples were collected in a clean and sterile stainless-steel container directly from the outlet of the biosolids storage tanks prior to being transferred to the portable farm spreader towed by the tractor during the application of biosolids to the fields. For soil sampling, composite samples were collected at each application field before and after the biosolids were applied to the field. For each of the application fields (AF 11-2, AF 11-4, and AF 11-6), a network of grid blocks was established for each field to aid in the random selection of soil sampling locations. The size and number of grid blocks established for each site varied in proportion to the size of the fields, but at least 12 soil cores were collected from each field for each sampling event. An example of the grid block established for field AF 11-6 is shown in figure 4 . For each sampling event, a stainless-steel hand auger was used to retrieve surface soil (from 0 to 6-inches deep) at two to three locations in each of four to six randomly selected grid blocks at the application field. The soil from each sampled location was composited in a stainless steel-mixing bowl, homogenized, and subdivided into appropriate sample containers for submittal to the analyzing laboratories. All sampling equipment used to collect the soil samples were cleaned and sterilized prior to use.

Soil samples also were collected from the background agricultural field (BF1) at the Cane Creek site (fig. 3) for laboratory analyses. This background agricultural field is used to grow cover and (or) row crops that routinely receive applications of commercial fertilizers; no biosolids have ever been applied to this field (David McKee, land owner, oral commun., 2011). Four soil samples (one in each season) were collected from background field BF1 using the same approach described previously. All four samples were analyzed for nutrients, metals, and fecal-indicator bacteria; one sample was also analyzed for contaminants of emerging concern. The analytical data for these samples were used to examine background constituent concentrations in an agricultural field having no inputs of biosolids. 


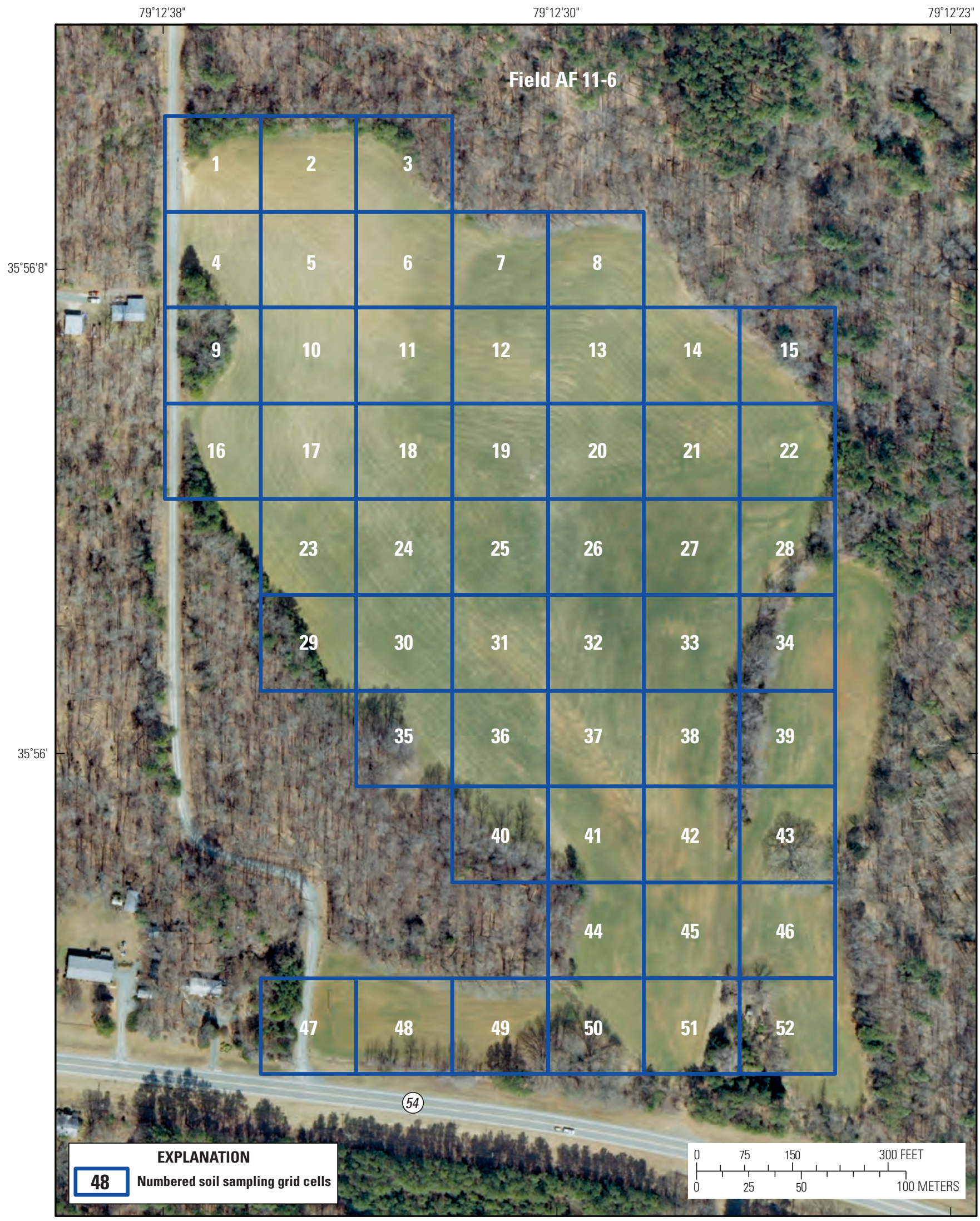

Base map imagery from City of Durham and NC 911 Board (6-inch resolution)

Figure 4. Example of the soil sampling grid at biosolids land-application field AF 11-6 in the Collins Creek watershed in Orange County, North Carolina. 


\section{Groundwater}

Groundwater information examined for this study includes the results of water-level monitoring and groundwater sampling for six shallow monitoring wells (table 1) installed in the transition zone, between the regolith and bedrock, at the Collins Creek biosolids study site and the Cane Creek background site. At the Collins Creek biosolids study site, four wells were installed along the edge of application fields (fig. 2) to monitor the potential influence of biosolids applications on shallow groundwater. Wells OR-685 and OR-688 were installed along the downgradient edge of application fields AF 11-5 and AF 11-7, respectively, adjacent to the riparian stream buffer (fig. 2). Wells OR-686 and OR-687 were installed along the upgradient edge and downgradient edge, respectively, of application field AF 11-6 (fig. 2). At the Cane Creek background site, two wells (OR-689 and OR-690) were installed along the edge of background field BF1 (fig. 3) to provide information on background groundwater conditions at an agricultural field having no inputs of biosolids.

The groundwater wells used in this study were installed by DWR. At each well location, a continuous soil and unconsolidated rock core was collected using a Geoprobe ${ }^{\circledR}$ direct push sampler with a 4-foot (ft) long, 2.125-inch diameter core barrel. Collected cores were sealed inside clear polyvinyl chloride (PVC) liners, marked for section correlation, and placed in storage. Soil profile descriptions by DWR staff for each well site are provided in appendix 1.

Upon completion of soil coring, each corehole was converted into a borehole for well installation using a Schramm T450 drill rig fitted with a 12-inch diameter airrotary drill bit. After reaching the prescribed borehole depth, the drill bit was removed and a 4-inch diameter schedule 40 PVC threaded well casing with a 10 -ft length of 0.01 -inch machine-slotted well screen was placed in the borehole. The annular space between the well screen and borehole wall was filled with clean sand to a height of $1 \mathrm{ft}$ above the top of the screen. Bentonite chips were poured above the sand filter pack to create a seal within the annular space up to $3 \mathrm{ft}$ below land surface. The remaining $3 \mathrm{ft}$ of annular space was filled with cement grout. A protective steel casing with a locking lid was installed over the PVC well casing extending above ground and a 4-ft by 4-ft concrete pad was poured into place. Well construction details are summarized in table 3 .

Table 3. Construction data for monitoring wells at the Collins Creek and Cane Creek watershed study sites in Orange County, North Carolina.

[ID, identification; USGS, U.S. Geological Survey; ft, feet; NAVD 88, NAVD 88, North Amercian Vertical Datum of 1988; BLS, below land surface]

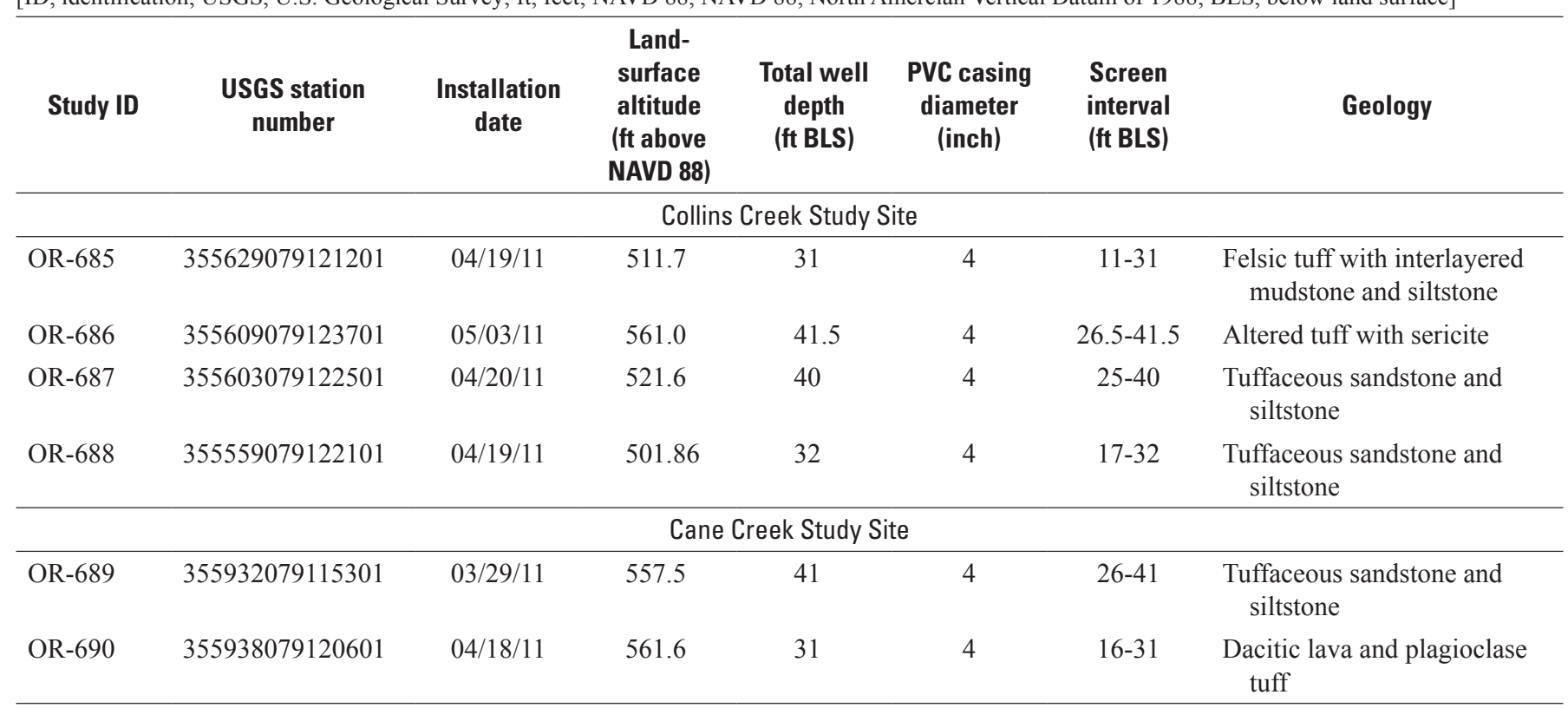




\section{Groundwater-Level Monitoring}

Groundwater-level measurements were collected approximately every 3 months from June 2011 to March 2013 to identify seasonal groundwater trends. Measurements were made using an electric water-level tape from a specified measuring point on the well casing, following techniques described by Cunningham and Schalk (2011). The measuring point and land-surface elevations at well OR-688 were surveyed in relation to a locally established benchmark to determine the elevation above the North American Vertical Datum of 1988 (NAVD 88). Land-surface altitudes at the remaining five monitoring well sites were derived from the USGS National Elevation Dataset (NED). The NED is based on source data from several local digital elevation models (DEMs) with an overall absolute vertical accuracy expressed as the root mean square error of 2.44 meters (Gesch, 2007). The underlying local light detection and ranging (lidar) data for the State of North Carolina have a vertical accuracy that is within 25 centimeters. All groundwater-level data are presented in feet above NAVD 88.

Continuous groundwater levels were collected in wells OR-685, OR-687, and OR-688 by the Orange County Department of Environment, Agriculture, Parks, and Recreation; these data are provided to the public by DWR as one data point per day (http://ncwater.org/?page $=537 \& t l=1 \&$ net $=$ orange\&inactive $=$, accessed October 8,2014 ). Continuous groundwater-level data from June 2011 to May 2013 were used in this report.

\section{Groundwater Sampling}

Eight sets of groundwater samples were collected from each well beginning in June 2011 and ending in March 2013. Samples were collected approximately every 3 months to represent seasonal differences. The groundwater samples were analyzed primarily for nutrients, major ions, total metals, fecal-indicator bacteria, and field alkalinity; selected samples also were analyzed for contaminants of emerging concern.

All groundwater samples were collected and processed following standard USGS guidelines (U.S. Geological Survey, variously dated). A multiparameter water-quality sonde and flowthrough chamber connected to the submersible pump discharge line were used to continuously monitor waterquality field properties ( $\mathrm{pH}$, specific conductance, dissolved oxygen, and water temperature). Pumping rate, drawdown, and field properties were monitored and documented during well purging. Three volumes of water were withdrawn from each well or the well was pumped until dry and allowed to recover prior to sample collection.

\section{Surface Water}

Surface-water quality sampling was conducted at a total of six locations (table 1), three of which were co-located with USGS streamgages (CO-SW1, CO-SW5, and CA-SW1) and are referred to herein as surface-water monitoring sites. The three stations that were not co-located with USGS streamgages (CO-SW2, CO-SW3, and CO-SW4; table 1) were manually sampled only twice during the study. Water-quality and streamflow data are available from 1988 through the present (April 2014) for Cane Creek (CA-SW1) at an existing USGS gaging station (02096846). As part of this study, a streamgage was installed and a stage-discharge relation was developed at each of the Collins Creek monitoring sites (CO-SW1 and CO-SW5) to compute continuous streamflow data. Water-quality monitoring was accomplished by installing automated samplers and stage recorders at the two monitoring sites on Collins Creek (fig. 2) and the one site on Cane Creek (fig. 3). The surface-water monitoring sites were sampled every 6 weeks (unless the streams were dry) for 2 years and 4 months to characterize stream constituent concentrations and flux upstream and downstream from biosolids application fields and from a watershed with no land application of biosolids. An additional 15 to 17 samples were collected during storm runoff conditions using automated samplers at each of the three surface-water monitoring sites. Data collected at the surface-water monitoring sites were used to document surface-water constituent concentrations and loadings from Collins and Cane Creek watersheds with and without land-applied biosolids, respectively.

\section{Stream-Discharge Monitoring}

The techniques and instrumentation used to measure and compute the continuous discharge record at the surface-water monitoring sites are presented in the subsequent section. Discharge was required to compute constituent loads in receiving streams from analyzed chemical concentrations.

Stream discharge was measured for a range of stream stages, and a stage-discharge rating curve was developed for each stream site during this investigation according to standard USGS methods (Rantz and others, 1982; Mueller and others, 2013; Turnipseed and Sauer, 2010). All three surface-water monitoring sites were equipped with DCPs that record and transmit stream stage at 15-minute intervals. Instantaneous streamflow was calculated from the established rating curve at the time that stream-stage records were transmitted to the USGS NWIS. Gage height or stream stage and discharge have been collected by the USGS at Cane Creek near Orange Grove (02096846) since 1988. The gaging stations at Collins Creek at Highway 54 near White Cross (0209691611) and Collins Creek above Secondary Route 1006 near White Cross (0209691590) were established on March 1, 2011, specifically for this study. 


\section{Surface-Water Sampling}

Surface-water samples were collected during baseflow and stormwater runoff conditions to be analyzed for chemical constituents and concentrations. Discrete storm samples were collected by an autosampler located at the surface-water monitoring sites primarily at the peak of the storm hydrograph with some selected samples collected on the rising and falling limbs of storm hydrographs. Surface-water samples were analyzed primarily for nutrients, major ions, metals, and bacteria. In addition, selected samples were analyzed for contaminants of emerging concern (including household-, industrial-, and agricultural-use compounds, pharmaceutical compounds, hormones, and antibiotics) and bacteria-related genetic biomarkers. Storm samples at the upstream and downstream Collins Creek sites and Cane Creek site were generally collected within 5 hours of each other.

When flow was sufficient and stream depth was wadeable, baseflow stream samples were collected using the integrated equal-width increment (EWI) sampling technique, which involves collecting an isokinetic width- and depthintegrated sample, composited in a splitter and processed and preserved according to USGS standard operating procedures (Edwards and Glysson, 1999; U.S. Geological Survey, 2006). When flow conditions did not permit EWI sampling, grab samples were collected at equal-width increments. Equal-width increment samples were collected using a DH-81 (Federal Interagency Sedimentation Project, 2001) or other suitable water-quality sampler.

When wading, samples to be analyzed for bacteria were collected at the midpoint of the stream by opening the bottle just below the surface of the water. Water temperature, specific conductance, $\mathrm{pH}$, dissolved oxygen, and barometric pressure were determined in the field at the time of sample collection. Field instruments were calibrated before each sampling period, and the results were documented along with the sample date and time.

\section{Laboratory Analyses}

Constituent classes and associated quality-control samples analyzed in various media by various laboratories are listed in table 4 . The bias, precision, and recovery as determined by the quality-control samples are discussed later in the report. Constituents analyzed in surface and groundwater at the USGS National Water Quality Laboratory (NWQL), method instrumentation, and reporting levels are listed in table 5. Constituents analyzed in biosolids and soils (solid phases) at the NWQL, method instrumentation, and reporting levels are listed in table 6 . With the exception of genetic biomarkers, constituents analyzed in all media at other USGS and outside laboratories are listed in table 7. As for the genetic biomarkers, Clarkson University conducted genetic biomarker analysis on biosolids, soil, and surface-water samples. Total genomic deoxyribonucleic acid (gDNA) was extracted directly from approximately 200 micrograms $(\mu \mathrm{g})$ of biosolids, cattle manure, and pre- and post-biosolids application soil by using the MoBio Powersoil Kit (MoBio, Carlsbad, California) as per the manufacturer's instructions. Water samples (100 milliliters) were filtered onto a 0.2 -micromho pore size polycarbonate filter (GE Water and Process Technologies, Trevose, Pennsylvania), and the DNA was extracted from the combined filter and retentate by using the MoBio Powersoil Kit as per the manufacturer's instructions. Salmon testes gDNA was added to all samples as an exogenous extraction and amplification control prior to bead milling, and in parallel bead tubes without sample.

Real-time quantitative polymerase chain reaction (qPCR) was used to measure recovery of salmon testes gDNA with and without sample to quantify DNA loss during the extraction procedure and to indicate potential sample inhibition as previously described (Rogers and others, 2011). Real-time qPCR was used to measure the presence of human (HumM2) and cattle (CowM1 and CowM2) biomarkers in DNA extracts as described by Shanks and others (2008, 2009) and total Bacteroidales 16S ribosomal DNA (rDNA) as measured by the GenBac3 assay first described by Dick and Field (2004). Conventional PCR for the CF128 marker was completed on the DNA extracts as described by Bernhard and Field (2000a,b), and amplicons were electrophoresed on a 2 percent agarose gel (FlashGel DNA System, Lonza) alongside a DNA ladder spanning the expected product size of 580 base pairs (bp). Total gDNA extract from cow manure collected on a dairy farm near Potsdam, New York, was used as a positive control for CowM1, CowM2, and the ruminant CF128 PCR biomarker. Deer feces collected near Potsdam, New York, were also used as a second positive control for the ruminant CF128 PCR biomarker, which is nondiscriminant between ruminant animals. Raw sewage collected from the influent of the Potsdam Sewage Treatment Plant (Potsdam, N.Y.) was used as a positive control for the HumM2 and HF183 biomarkers. All PCR reactions were conducted on a Roche Lightcycler 480. Standard curves for the qPCR assays HumM2, CowM1, and CowM2 spanned 5 to 50,000 DNA copies, and correlation coefficients and reaction efficiencies for CowM1 were 0.9879 and 109.3 percent, respectively, for CowM2 were 0.9794 and 95.18 percent, respectively, and for HumM2 were 0.9928 and 99.46 percent, respectively. The standard curve for salmon testes qPCR spanned 0.0031-30.8 nanogram per microliter genomic DNA, and the correlation coefficients and reaction efficiencies were 0.9975 and 103.49 percent, respectively. Positive controls and no template controls were included on all conventional PCR and $\mathrm{qPCR}$ reaction plates to assure positive amplification and to monitor for potential contamination. All positive control reactions amplified the gene of interest, and all no template control reactions were negative throughout the study. 
Table 4. Media, analyzing laboratories, and types of quality-control samples analyzed for each constituent class.

[USGS, U.S. Geological Survey; Inc., incorporated; N/A, not applicable]

\begin{tabular}{|c|c|c|c|c|c|c|}
\hline Medium & Analyzing laboratory & Constituent class & $\begin{array}{l}\text { Field } \\
\text { blanks }\end{array}$ & $\begin{array}{l}\text { Field repli- } \\
\text { cates }\end{array}$ & $\begin{array}{l}\text { Matrix } \\
\text { spikes }\end{array}$ & $\begin{array}{l}\text { Reference } \\
\text { materials and } \\
\text { solutions }\end{array}$ \\
\hline \multirow[t]{6}{*}{ Soil } & $\begin{array}{l}\text { USGS National Water Quality } \\
\text { Laboratory }\end{array}$ & $\begin{array}{l}\text { Emerging contaminants (waste- } \\
\text { water compounds, hormones, } \\
\text { pharmaceuticals) }\end{array}$ & N/A & No & No & No \\
\hline & $\begin{array}{l}\text { USGS Kansas Water Science } \\
\text { Center }^{1}\end{array}$ & Antibiotics & N/A & No & No & No \\
\hline & Pace Analytical Services, Inc. & Metals, nutrients & N/A & Yes & No & Yes \\
\hline & Pace Analytical Services, Inc. & Bacteria & $\mathrm{N} / \mathrm{A}$ & Yes & No & No \\
\hline & TestAmerica & Hydrocarbons, oil \& grease, etc. & N/A & No & Yes & No \\
\hline & Clarkson University & Genetic biomarkers & N/A & No & Yes & Yes \\
\hline \multirow[t]{5}{*}{ Biosolids } & $\begin{array}{l}\text { USGS National Water Quality } \\
\text { Laboratory }\end{array}$ & $\begin{array}{l}\text { Emerging contaminants (waste- } \\
\text { water compounds, hormones, } \\
\text { pharmaceuticals) }\end{array}$ & N/A & No & Yes & No \\
\hline & Pace Analytical Services, Inc. & Metals, nutrients & $\mathrm{N} / \mathrm{A}$ & Yes & Yes & Yes \\
\hline & Pace Analytical Services, Inc. & Bacteria & N/A & Yes & No & No \\
\hline & TestAmerica & Hydrocarbons, oil \& grease, etc. & N/A & Yes & Yes & No \\
\hline & Clarkson University & Genetic biomarkers & N/A & No & Yes & Yes \\
\hline \multirow[t]{3}{*}{ Streams } & $\begin{array}{l}\text { USGS National Water Quality } \\
\text { Laboratory }\end{array}$ & Ions, nutrients & Yes & Yes & No & No \\
\hline & $\begin{array}{l}\text { USGS National Water Quality } \\
\text { Laboratory }\end{array}$ & $\begin{array}{l}\text { Emerging contaminants (waste- } \\
\text { water compounds, hormones, } \\
\text { pharmaceuticals) }\end{array}$ & Yes & No & Yes & No \\
\hline & Clarkson University & Genetic biomarkers & No & No & Yes & Yes \\
\hline \multirow[t]{5}{*}{ Groundwater } & $\begin{array}{l}\text { USGS National Water Quality } \\
\text { Laboratory }\end{array}$ & Ions, nutrients & Yes & Yes & No & No \\
\hline & $\begin{array}{l}\text { USGS National Water Quality } \\
\text { Laboratory }\end{array}$ & $\begin{array}{l}\text { Emerging contaminants (waste- } \\
\text { water compounds, hormones, } \\
\text { pharmaceuticals) }\end{array}$ & Yes & Yes & No & No \\
\hline & $\begin{array}{l}\text { USGS Kansas Water Science } \\
\text { Center }\end{array}$ & Antibiotics & Yes & No & No & No \\
\hline & $\begin{array}{l}\text { North Carolina Department of } \\
\text { Environment and Natural } \\
\text { Resources }\end{array}$ & $\begin{array}{l}\text { Metals, total suspended and } \\
\text { dissolved organic carbon and } \\
\text { solids }\end{array}$ & Yes & Yes & No & Yes \\
\hline & Pace Analytical Services, Inc. & Bacteria & Yes & Yes & No & No \\
\hline
\end{tabular}

${ }^{1}$ Data were not available at the time of this writing. 


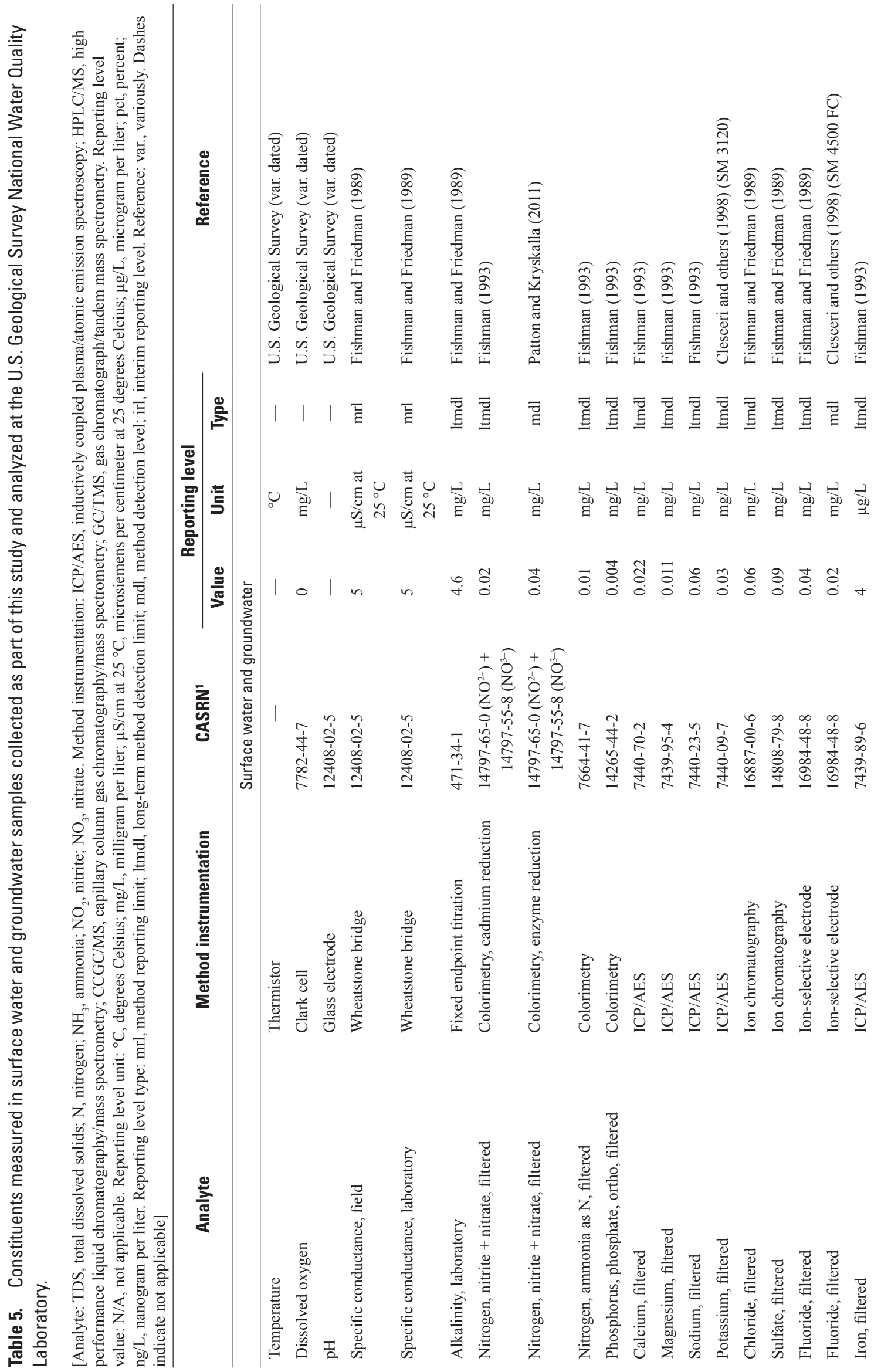




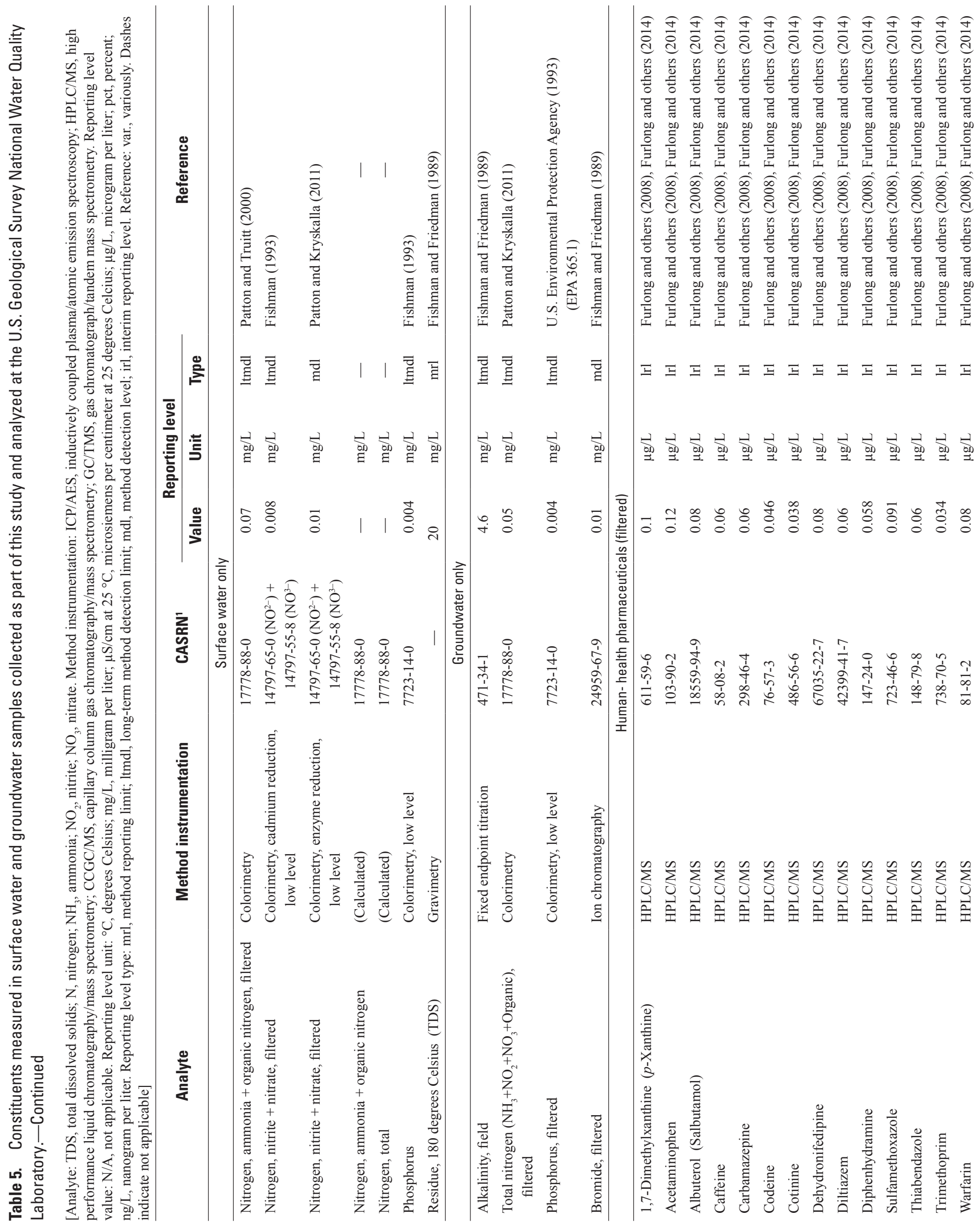




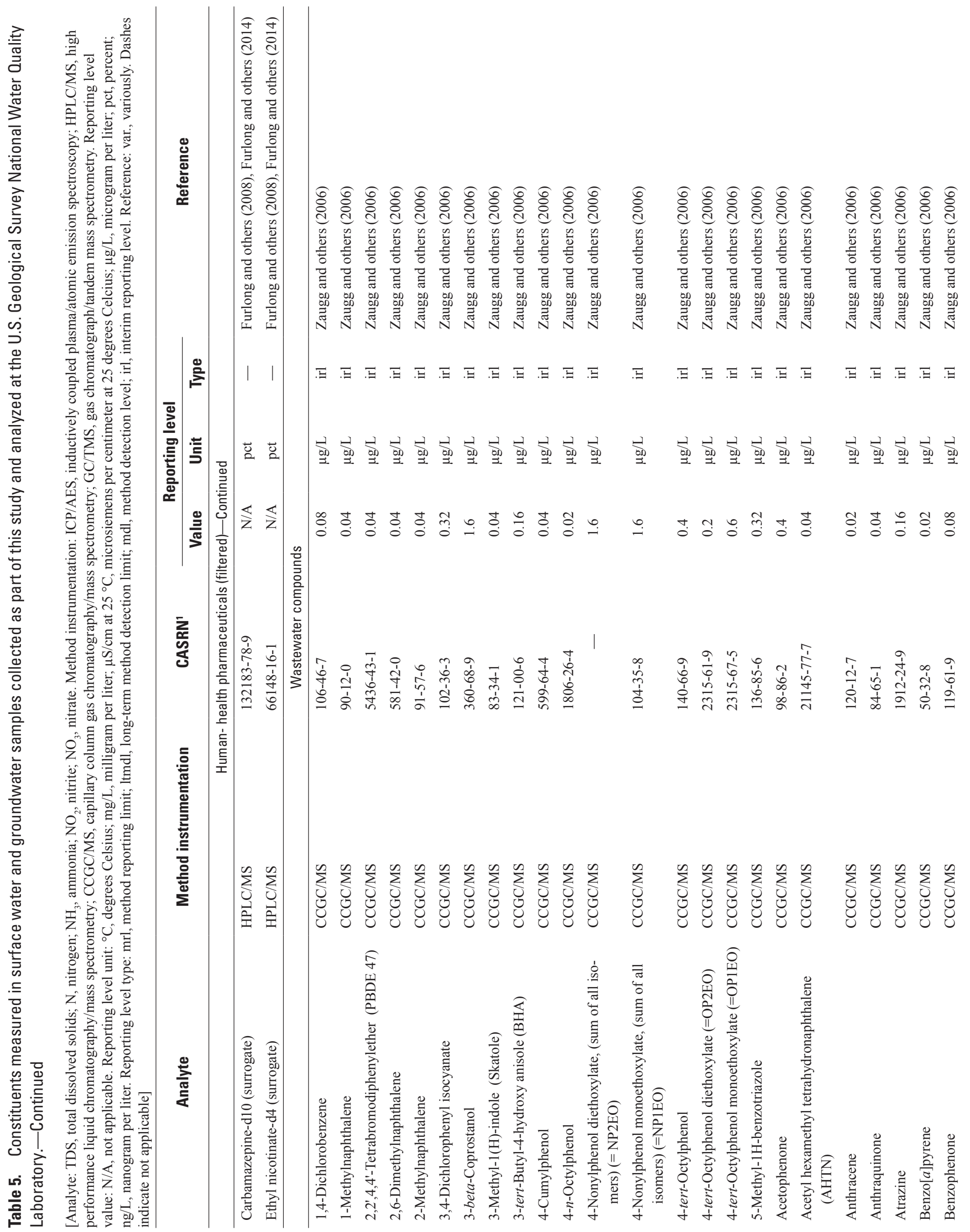




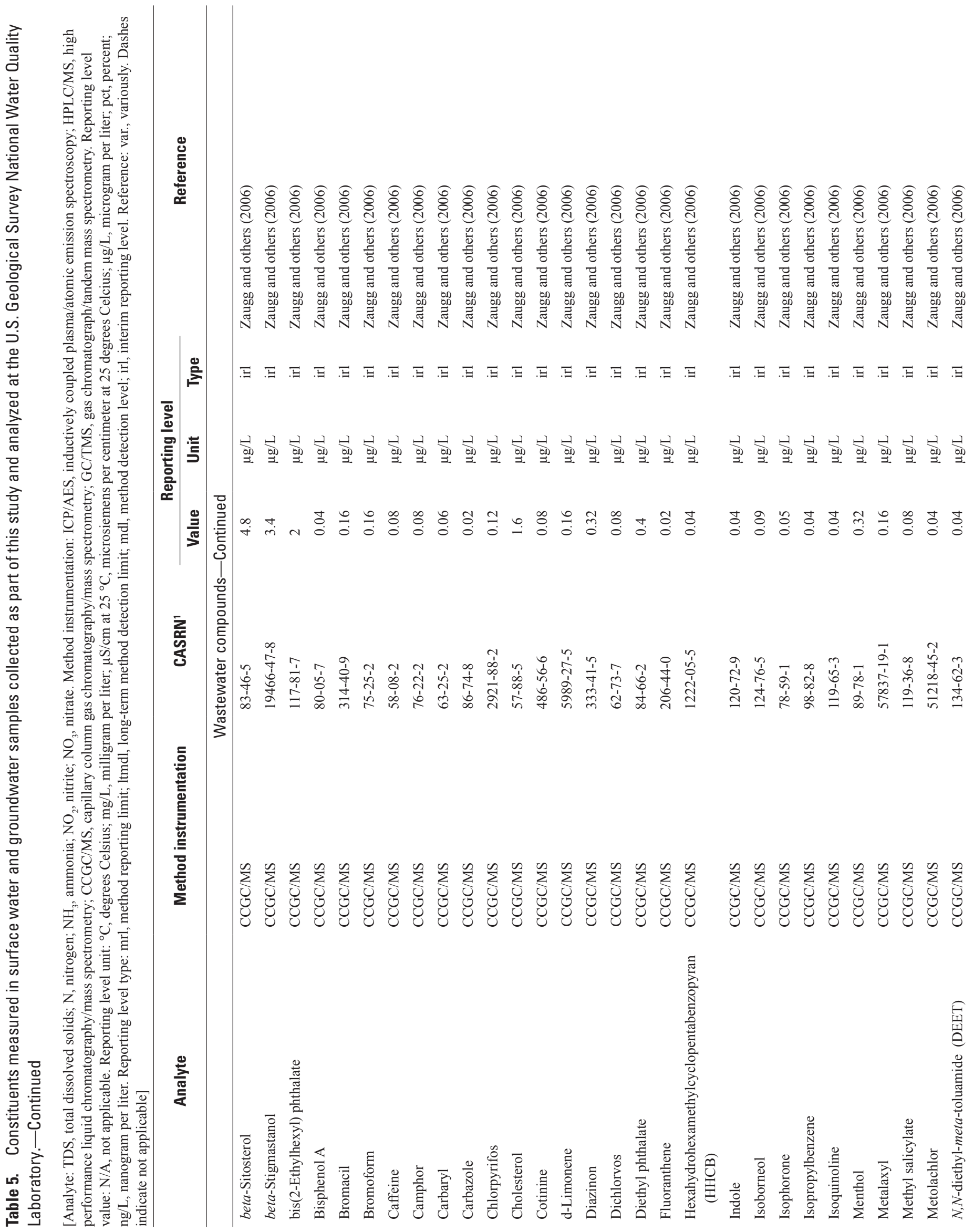




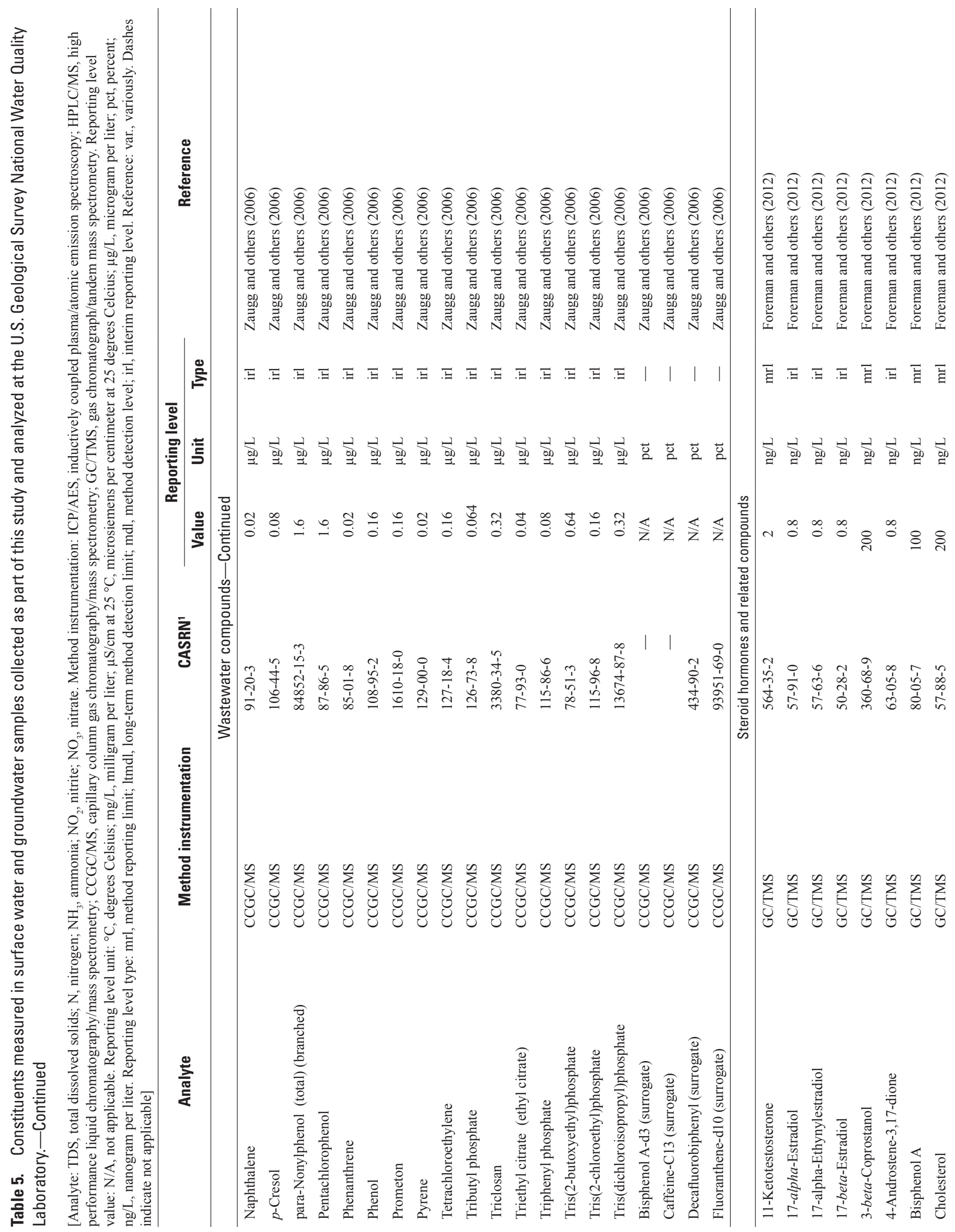




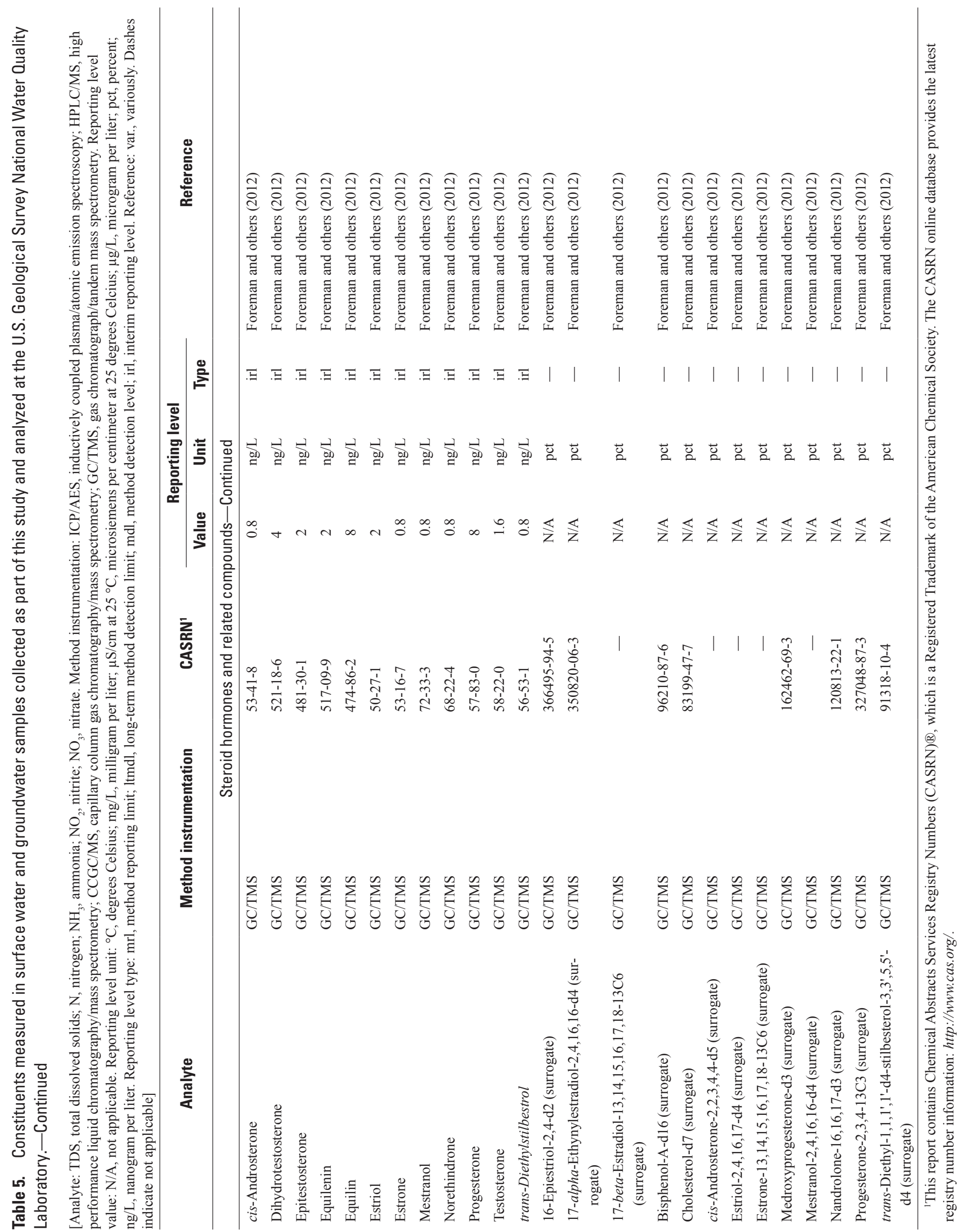




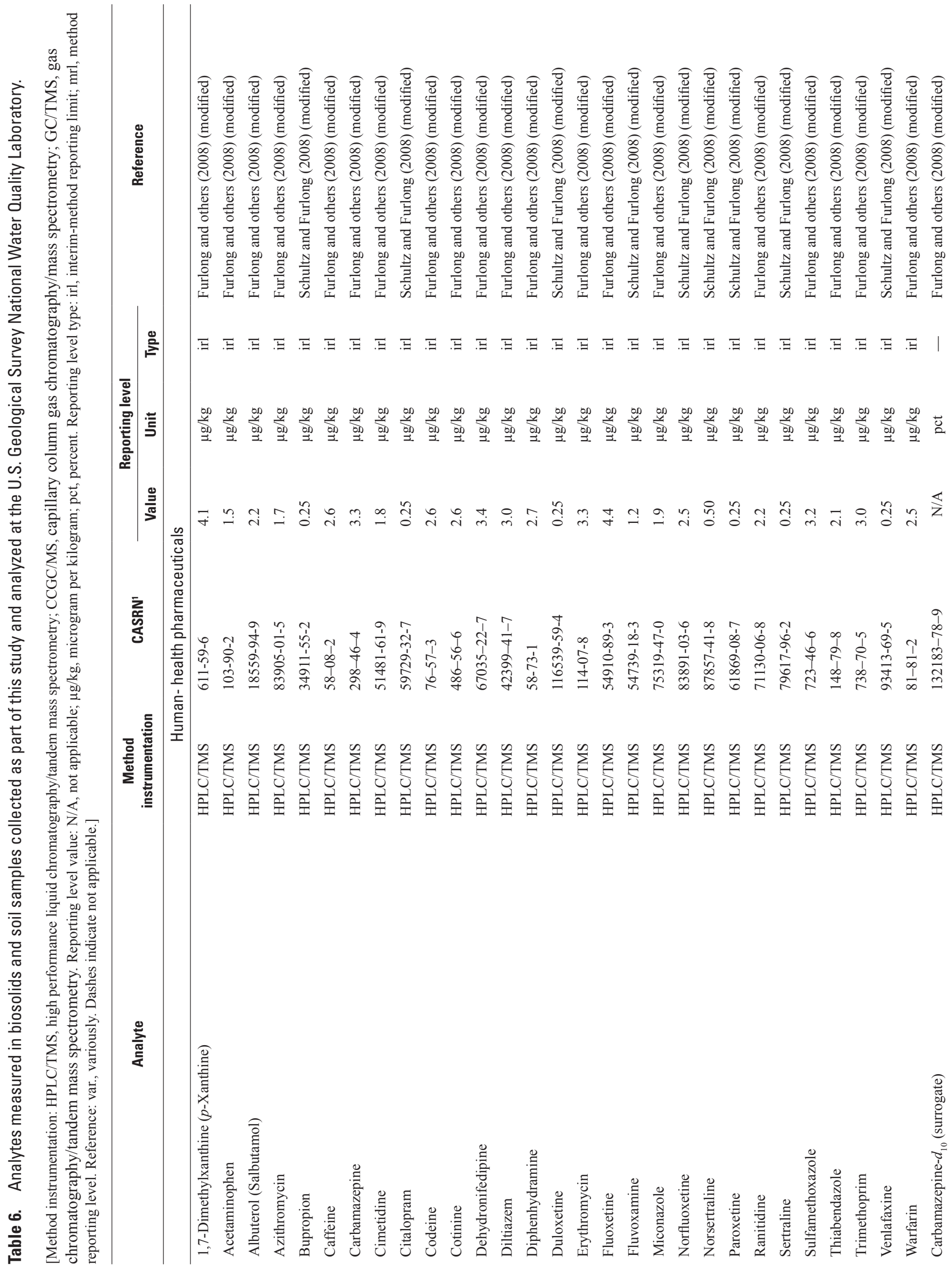




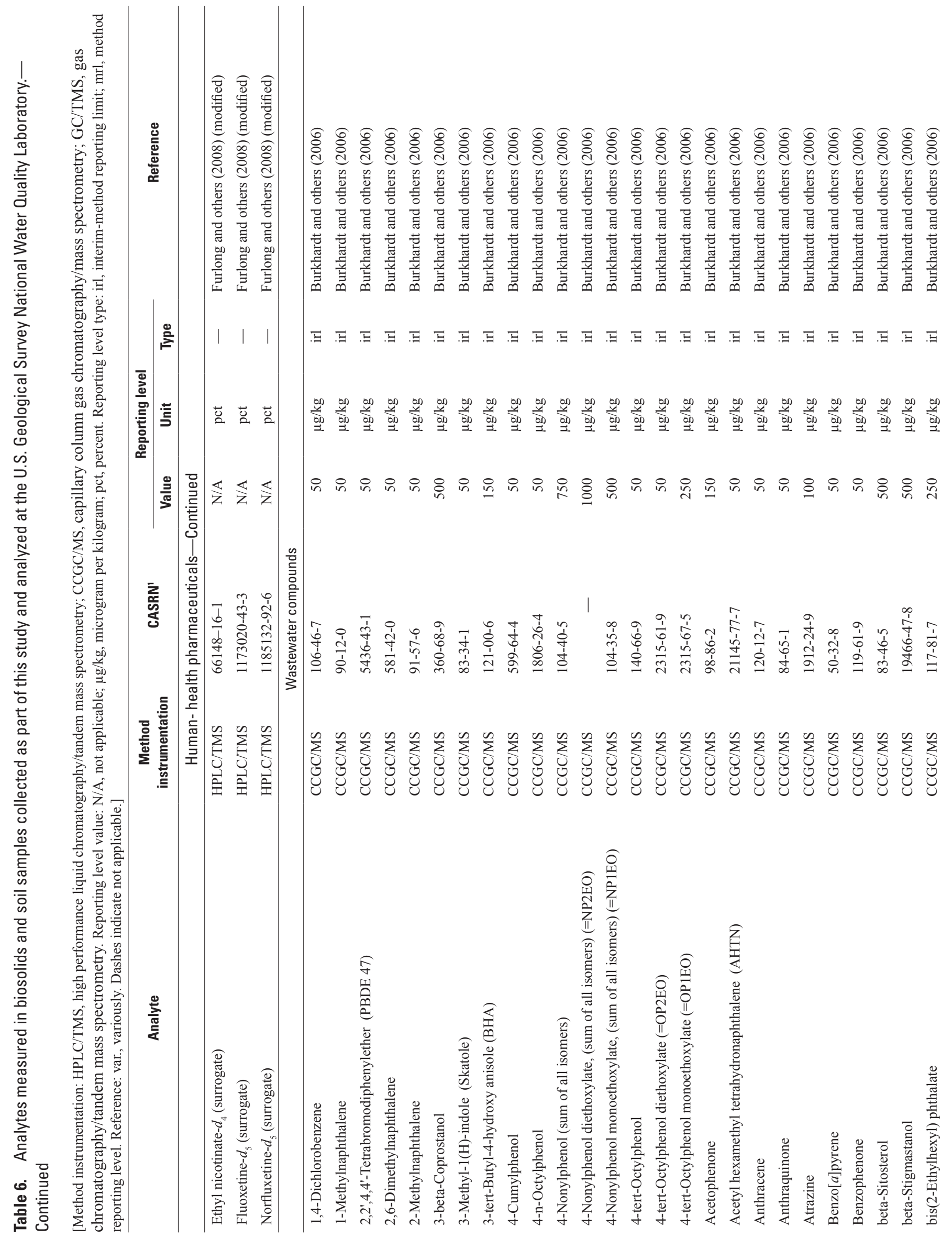




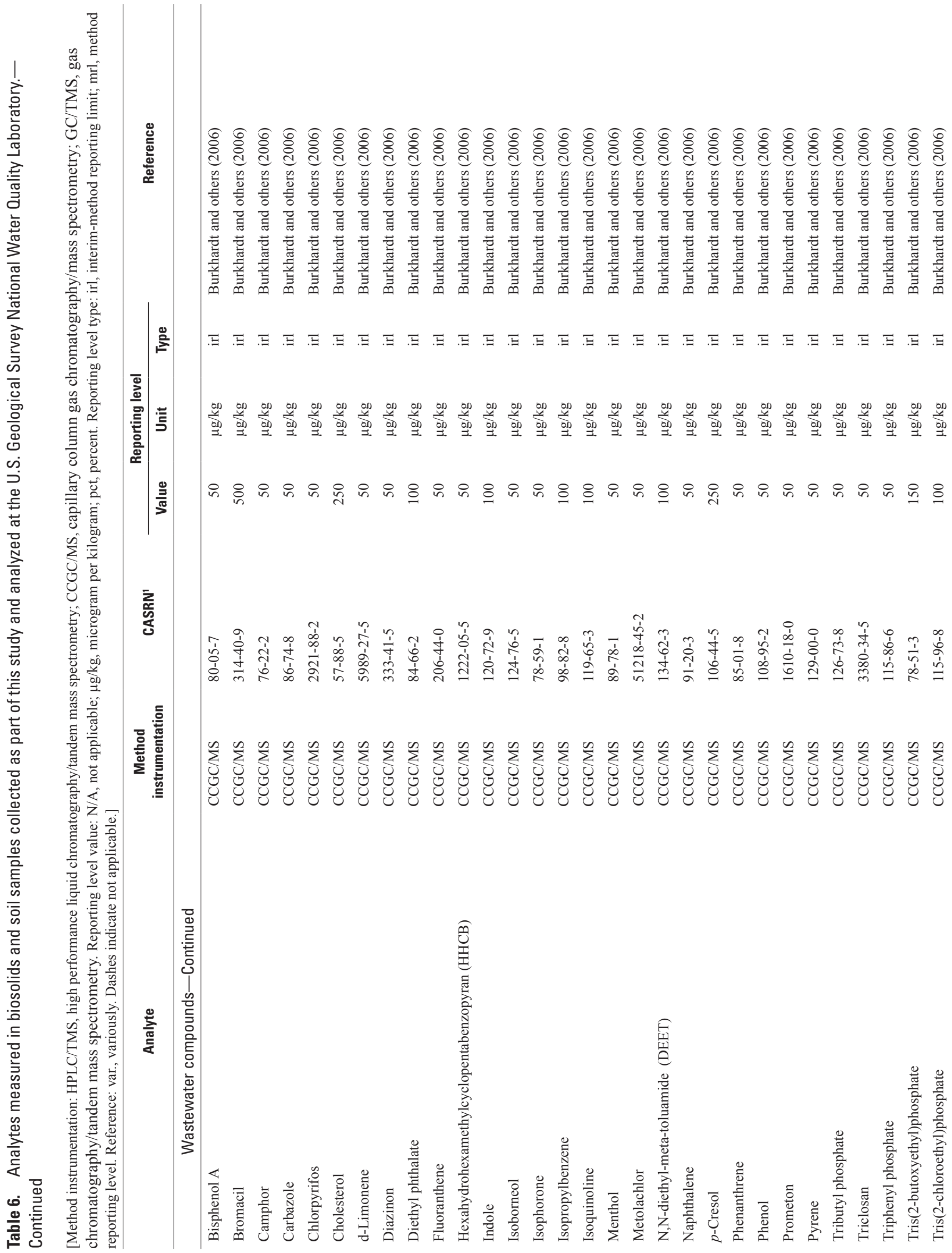




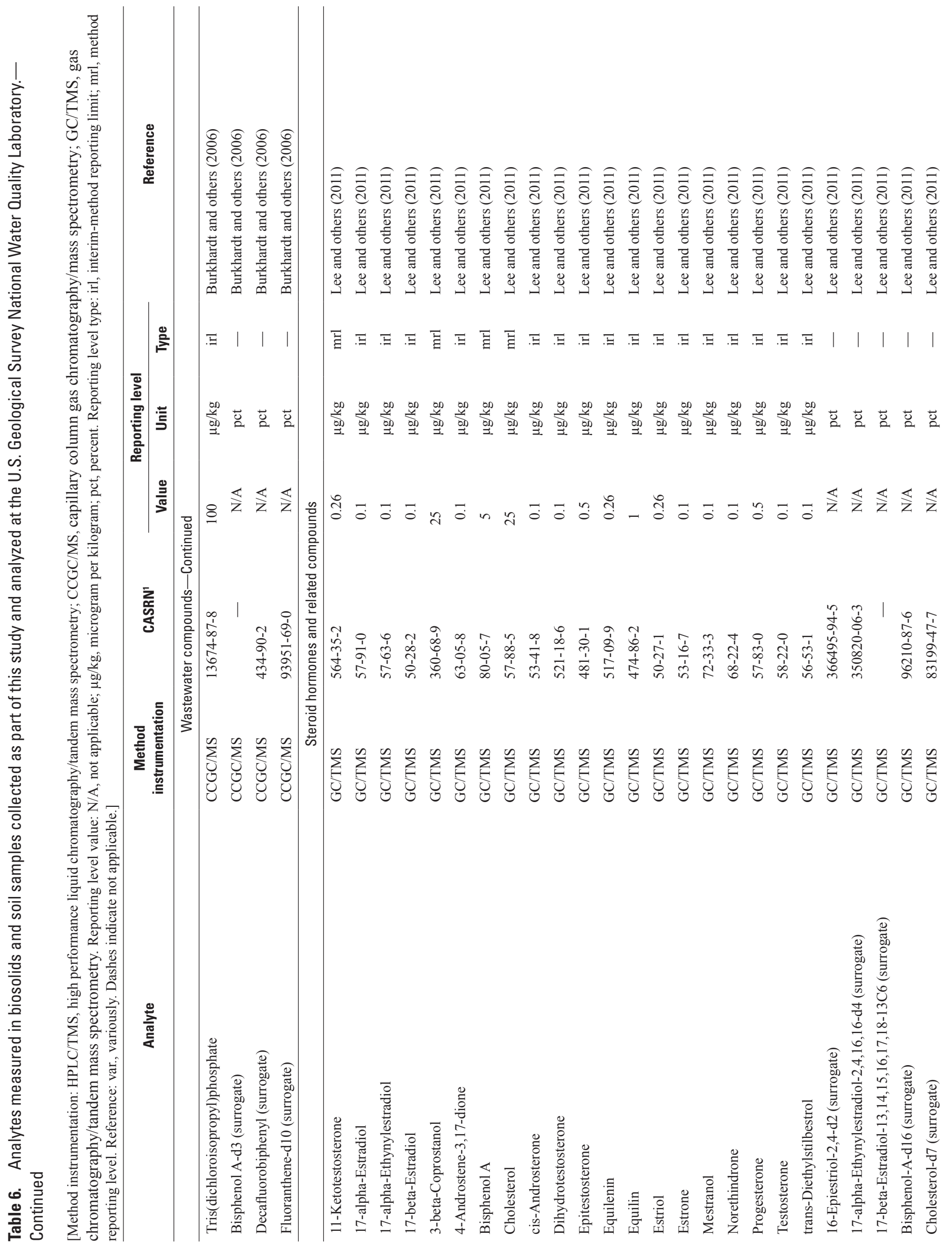




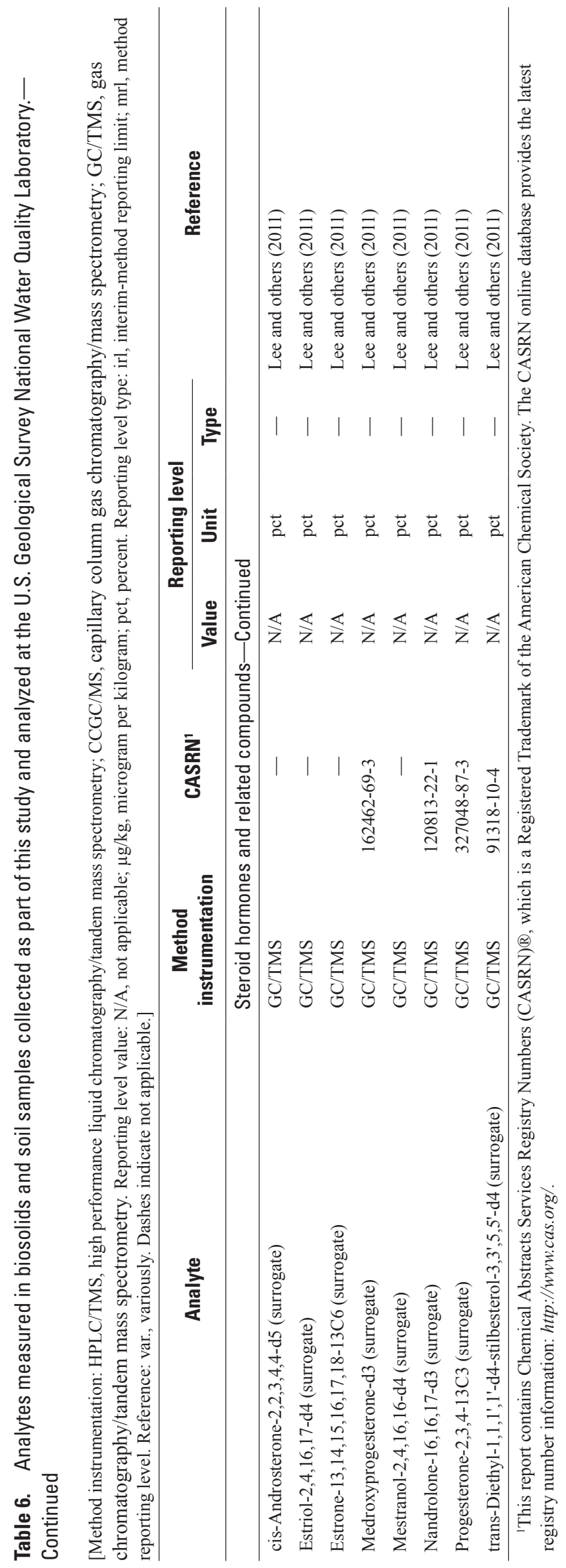




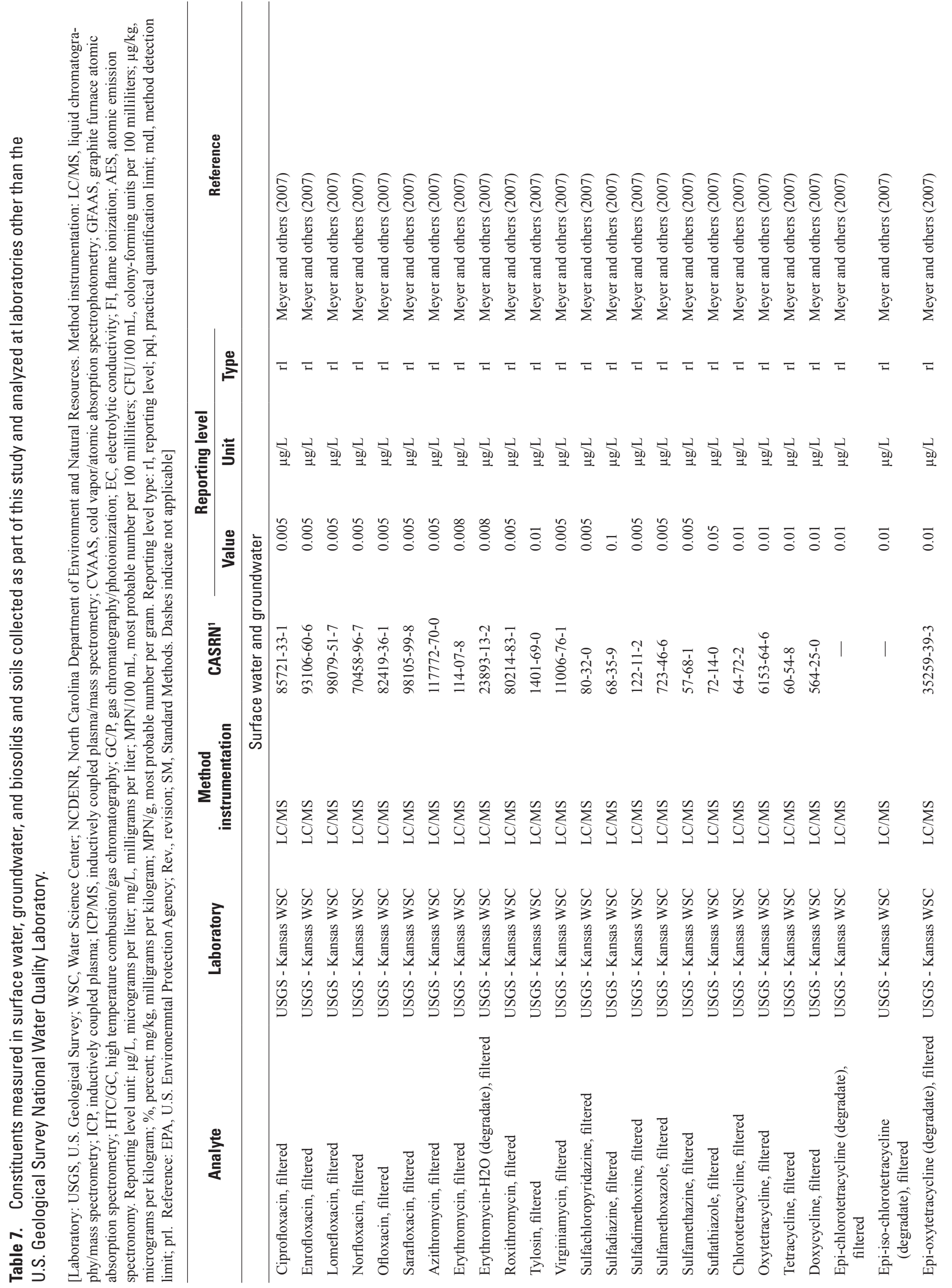




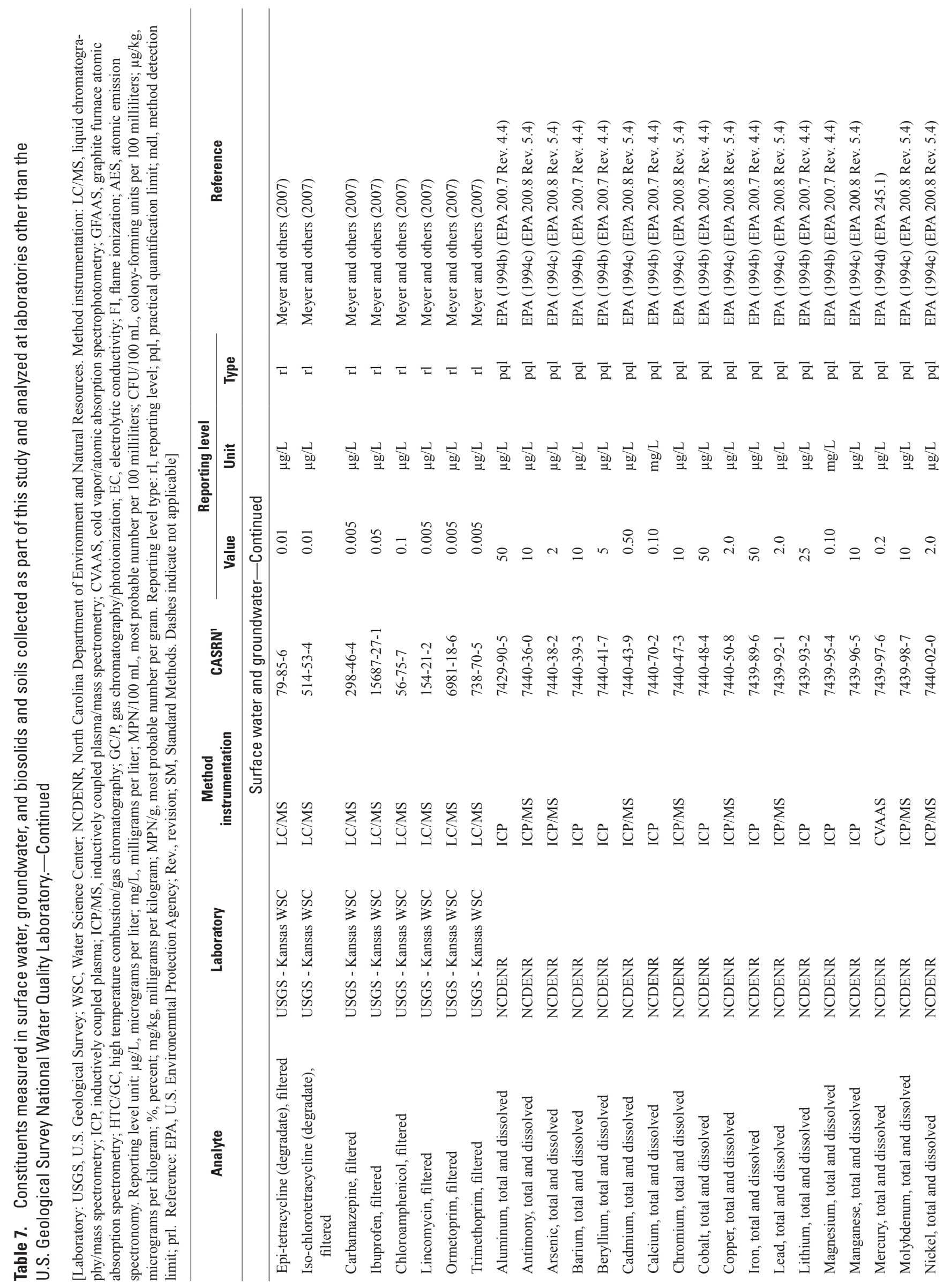




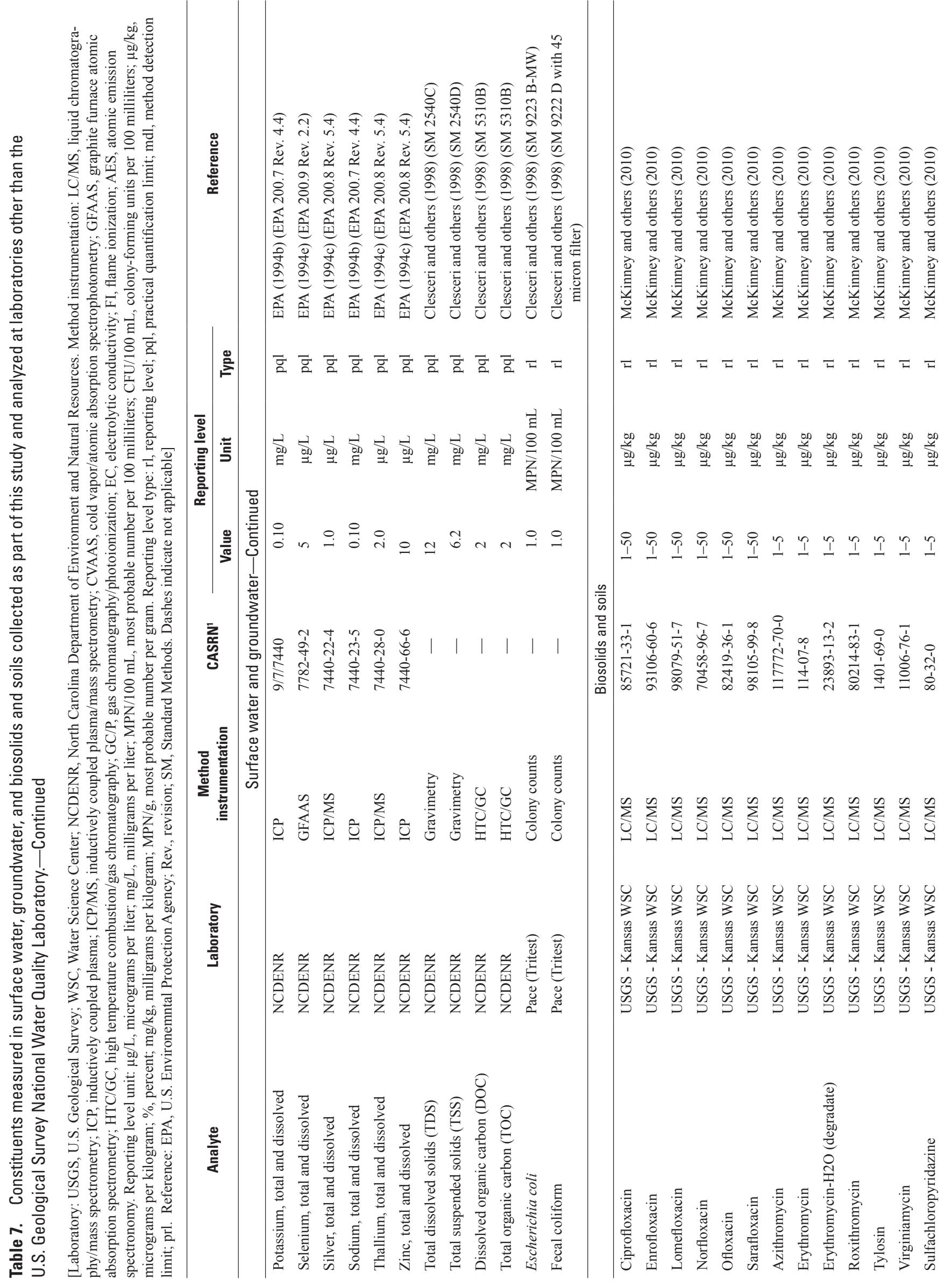




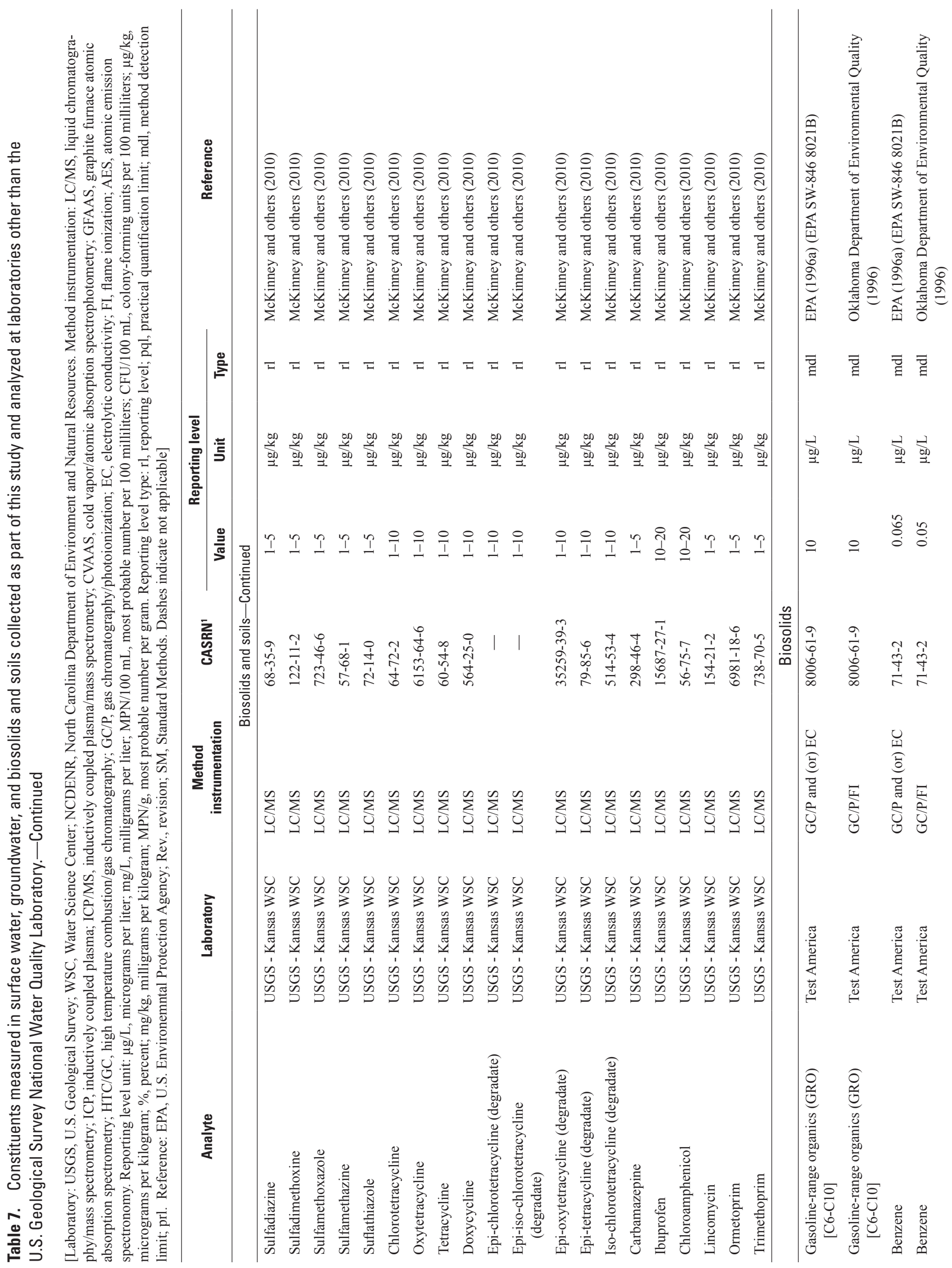




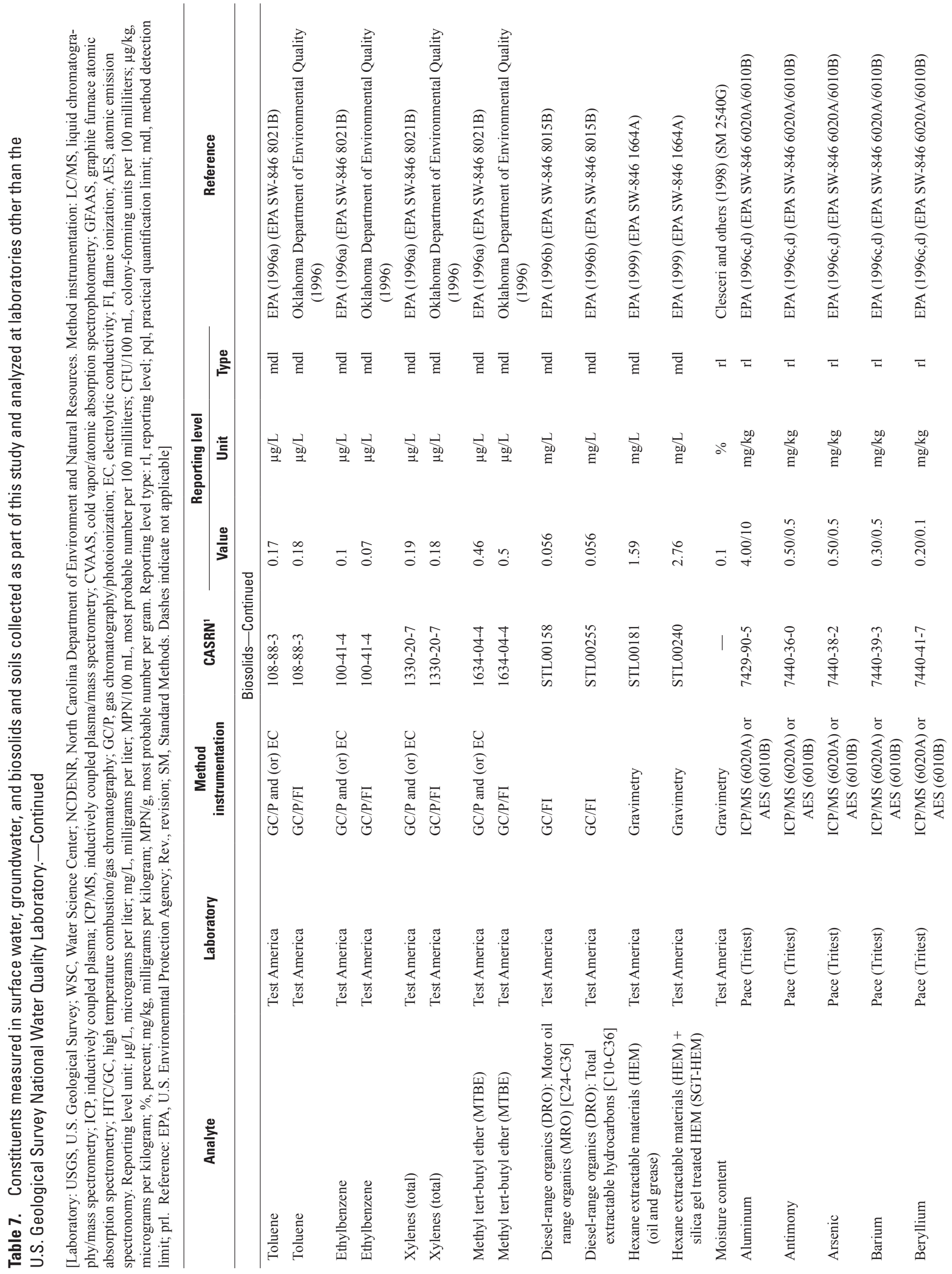




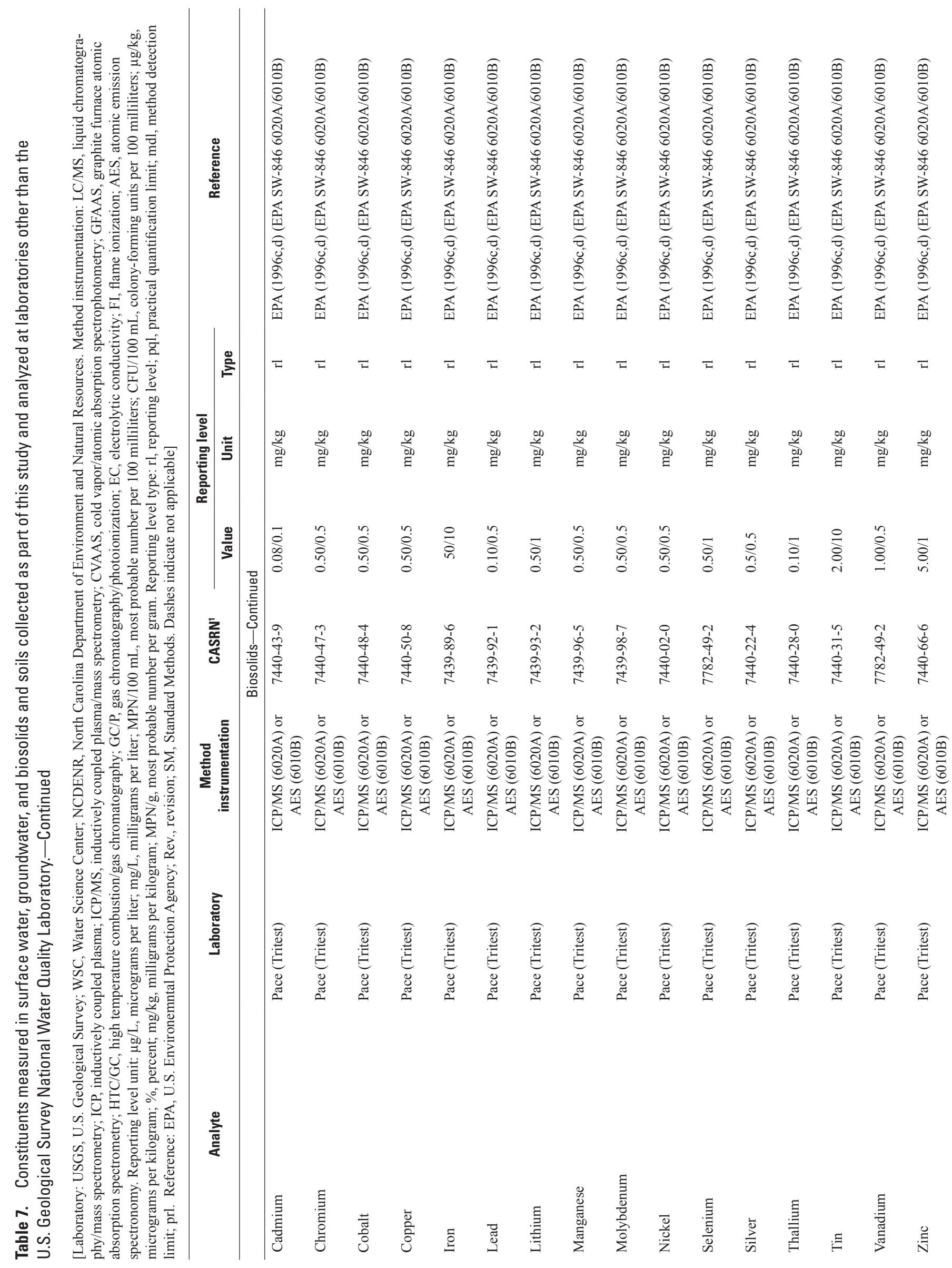




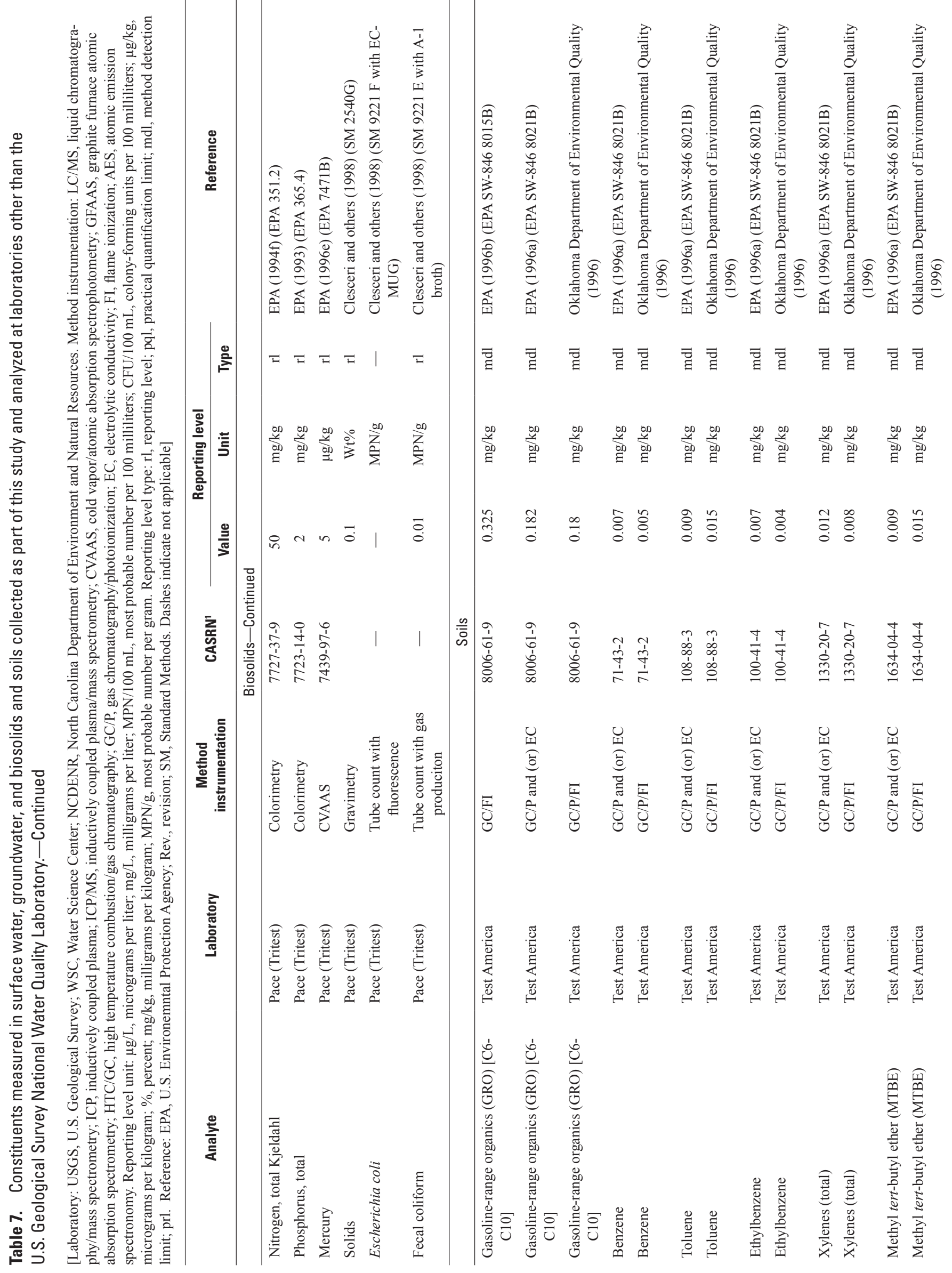




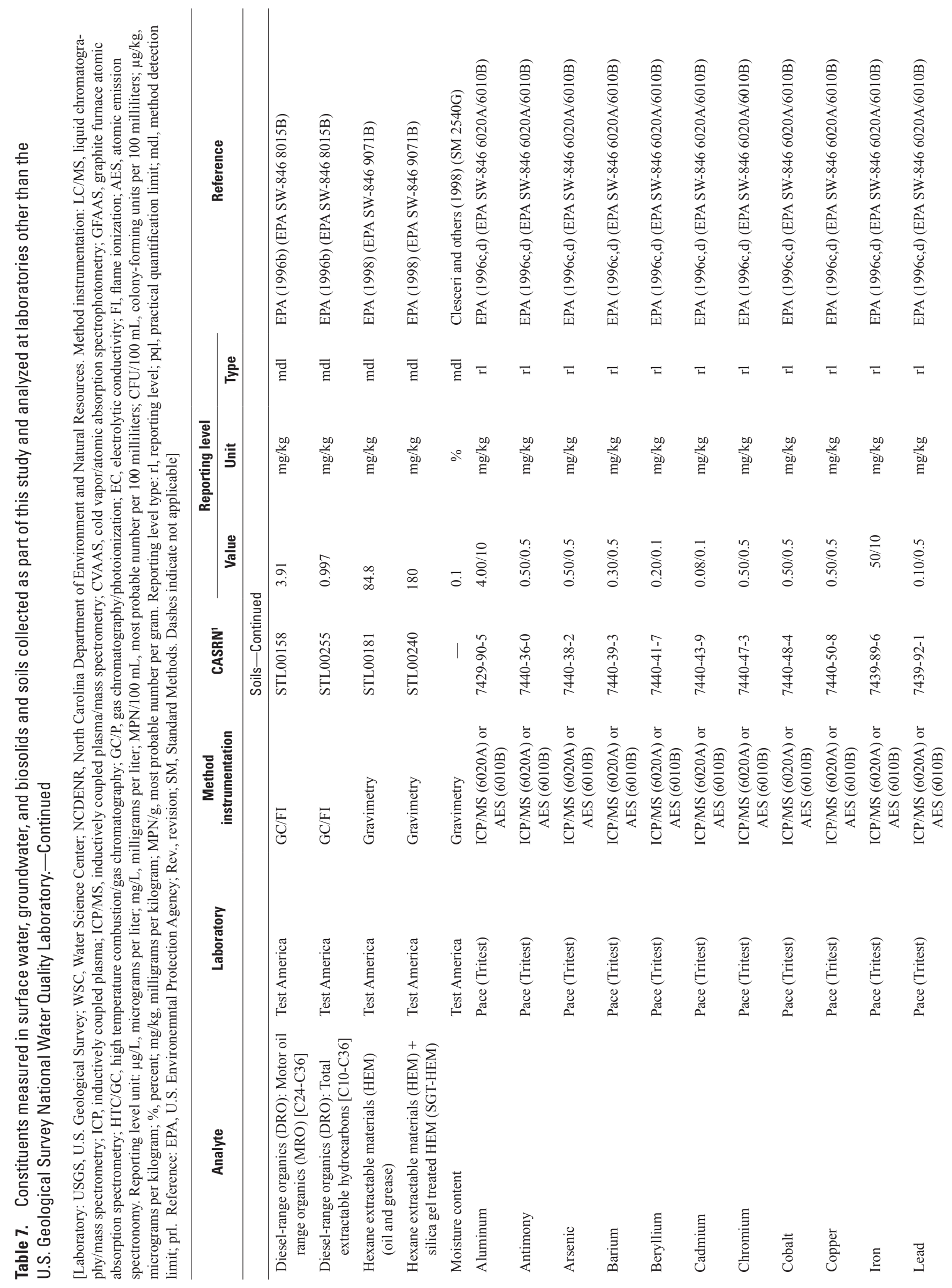




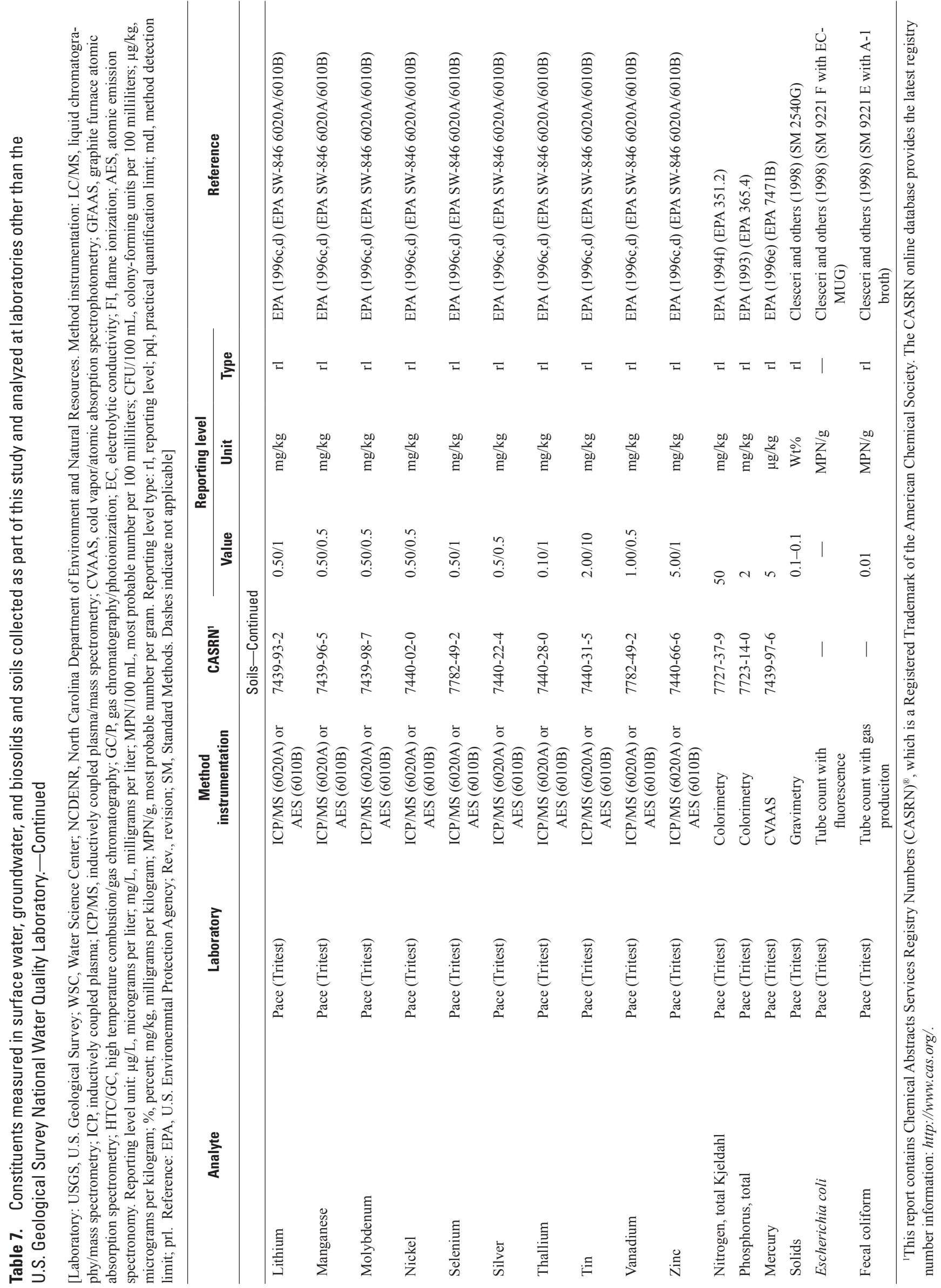


The water-quality data for all study sites were retrieved from the USGS NWIS database (http://waterdata.usgs.gov/nc/ nwis/, accessed October 10,2014). The data contain any reported laboratory values and associated remark codes, including censored values such as less than $(<)$ laboratory reporting level (LRL). All constituent concentrations not listed in the tables in the body of the report are in appendix tables 2-1 (non-EPAregulated elements and weight percent solids of solid phases), 2-2 (contaminants of emerging concern in solid phases), 2-3 (groundwater), and 2-4 (surface water). Analytical concentrations for the nitrogen species are reported in milligrams per liter as nitrogen, and concentrations for orthophosphorus (ortho-P) and total phosphorus (TP) are reported in milligrams per liter as phosphorus. Some analytical results are coded to indicate various conditions or quality of the data. Results coded with an "E" indicate an estimated value above the method detection level but below the LRL. Although estimated values are considered semiquantitative, these values were included in the study interpretation. It is important to note that estimated values (E-coded) are considered to be more qualitative (presence/absence) than quantitative and so, for example, a result of E 0.04 is not necessarily greater than a result of E 0.02 . Results coded with a "V" indicate significant and frequent presence in laboratory blanks. These values generally were not included in the study interpretation unless the environmental sample contained at least 10 times the highest concentration in a laboratory (set, reagent, and so forth) blank.

The nutrient data for surface-water sites were retrieved from the NWIS database and include computed values for total organic nitrogen $(\mathrm{N})$ and total nitrogen $(\mathrm{TN})$, which are calculated from directly measured nutrient constituents listed in table 5. Concentrations of total organic $\mathrm{N}$ were computed by subtracting the dissolved ammonia concentration from the total ammonia plus organic $\mathrm{N}$ (also known as total Kjeldahl nitrogen or TKN) concentration. Concentrations of TN were computed by summing the measured concentrations of total ammonia plus organic $\mathrm{N}$ and dissolved nitrate plus nitrite as $\mathrm{N}$. Note that if one of the underlying constituents used in computing total organic $\mathrm{N}$ or TN was censored at the LRL $(<)$ value, then the censoring (" $<"$ " remark code) is automatically carried forward with the computed value.

Total ammonia plus organic $\mathrm{N}$ concentrations were at levels well above the LRL of 0.07 milligram per liter $(\mathrm{mg} / \mathrm{L})$ in all but one of the 103 surface-water samples. However, almost 30 percent of the ammonia and 6 percent of the nitrate plus nitrate concentrations were censored, producing the need to carry forward censoring to the computed $\mathrm{N}$ values. Therefore, for the purpose of data evaluations in this study, censored total organic $\mathrm{N}$ and TN values were used as actual values because the censoring levels associated with the dissolved ammonia $(0.010 \mathrm{mg} / \mathrm{L}$ as $\mathrm{N})$ and dissolved nitrate plus nitrite $(0.04 \mathrm{mg} / \mathrm{L}$ as N) have minimal positive bias effect on the calculated values for total organic $\mathrm{N}$ and TN, respectively. Thus, examinations of the total organic $\mathrm{N}$ and TN data were based on the concentration values as directly reported in appendix tables 2-3 and 2-4 without regard to any censoring assigned to the values.

\section{Quality-Assurance and Quality-Control Design}

As the Nation's principal Earth-science information agency, the USGS has developed a worldwide reputation for collecting accurate data and producing factual and impartial interpretive reports. To ensure continued confidence in its products, all scientific work by the USGS is conducted in accordance with documented quality assurance and quality control (QA/QC) policies and procedures.

The USGS Quality-Assurance Plan for Water-Resources Activities in North Carolina (U.S. Geological Survey, 2010a) provides a framework for defining the precision and accuracy of collected data. The plan is supported by a series of qualityassurance policy statements that describe responsibilities for specific functional elements including project planning and implementation, equipment calibration and maintenance, data collection, data processing and storage, data analysis and interpretation, synthesis, reports preparation and processing, and training. Activities of the USGS South Atlantic Water Science Center are systematically conducted under a hierarchy of supervision and management that is designed to ensure conformance with agency goals of quality assurance.

In addition to following standard sampling and handling protocols as specified in the National Field Manual (USGS, variously dated), the USGS Branch of Quality Systems (BQS) operates several quality-assurance programs to help document the quality of study results (table 8). For analyses done at the NWQL, these include double-blind analyses of blanks for organic and inorganic constituents and provision of graphical and tabular control data for the analytical lines. Yearly proficiency testing of personnel is conducted on collection of field data including temperature, $\mathrm{pH}$, dissolved oxygen, alkalinity, and specific conductivity. The BQS also provides standard reference samples of water for blind submission to both the NWQL and outside laboratories. Lastly, the Laboratory Evaluation Program (LEP) is a formalized reporting avenue to document the ability of laboratories, internal and external, to meet data quality objectives of the study. All of these programs, both those designed for USGS and non-USGS laboratories, were used in this study to ensure, quantify, and document the data quality.

Detailed discussion of the study's QA/QC design and results, including estimates of variability, recovery, and bias determined from $\mathrm{QA} / \mathrm{QC}$ samples in all media, are shown in associated tables and figures in appendix 3. A general summary of the QA/QC results is presented in this section.

For each study site, the analytical results and associated laboratory remarks were reviewed to identify questionable sample results and obvious outliers. Any data that were rejected because of data quality concerns were designated as such in NWIS and were not used in the analyses presented in this report. Many constituents performed well and required no caveat. Some constituents have unknown performance due to a lack of quality-assurance samples (table 4), constituents in replicates that were present below the detection levels, and spiked constituent masses that constituted only a small percentage of those present in the sample, among other reasons. Constituents that were 
Table 8. Selected quality-assurance programs for water and solid phase chemical analyses operated by the U.S. Geological Survey Branch of Quality Systems and the National Water Quality Laboratory.

\begin{tabular}{|c|c|c|}
\hline Program & Description & Matrix \\
\hline Blind Blank Program (BBP) & $\begin{array}{l}\text { The BBP submits double blind blank samples to the National Water } \\
\text { Quality Laboratory (NWQL) to help determine method detection } \\
\text { levels and to monitor analytical performance. Samples are prepared } \\
\text { weekly for every possible analytical line. The same bottles and } \\
\text { preservatives are used as the USGS field personnel. Data are } \\
\text { collected and analyzed for trends, cycles, and biases. Online charts } \\
\text { are posted once a week so analysts and supervisors can assure } \\
\text { quality data. }\end{array}$ & Water \\
\hline Organic Blind Sample Program (OBSP) & $\begin{array}{l}\text { The OBSP assesses the operational performance of organic analyti- } \\
\text { cal methods used for determining water-quality parameters for the } \\
\text { NWQL by means of blind submissions of Quality Assurance (QA) } \\
\text { samples. }\end{array}$ & Water \\
\hline $\begin{array}{l}\text { National Field Quality Assurance } \\
\text { Program (NFQA) }\end{array}$ & $\begin{array}{l}\text { The NFQA was created in } 1979 \text { to provide quality-assurance refer- } \\
\text { ence samples to field personnel who make water quality field } \\
\text { measurements. The program monitors the proficiency of alkalinity, } \\
\text { pH, and specific conductance measurements determined by water } \\
\text { quality field analysts. }\end{array}$ & Water \\
\hline Laboratory Evaluation Program (LEP) & $\begin{array}{l}\text { Analytical laboratories that provide chemical, radiochemical, and } \\
\text { biological analyses to the U.S. Geological Survey, Water Resources } \\
\text { Discipline (WRD), must be evaluated relative to the objectives of } \\
\text { a project requiring analyses and approved for use for that specific } \\
\text { project. }\end{array}$ & Water and sediment \\
\hline
\end{tabular}

Information from http://bqs.usgs.gov/.

highly variable between replicates, had very low or incorrectly high recovery in spiked samples, and (or) were detected at relative high levels in blanks are summarized in table 9. Biosolids constituents with concentrations that varied by more than 30 percent and were associated with relatively large absolute concentration differences included mercury, four wastewater compounds, and two hydrocarbon constituents. For soil, only chromium was included in this category though it should be noted that no replicates were analyzed for emerging compounds in soil. Several constituents in surface and groundwater varied by more than 30 percent between replicates, although only Escherichia coli (E. coli) in surface water and fecal coliform in both surface and groundwater were associated with relatively large absolute concentration differences.

The recovery of most metals and nutrients in biosolids and soil and the recovery of major ions and nutrients in surface and groundwater were quite good. Only a few metals (aluminum, manganese, and mercury in biosolids and antimony in soil) had an unsatisfactory recovery. For mercury, the need to estimate the recoverable fraction of the total in the standard reference material may have contributed to the poor apparent recovery. In contrast to the metals, most of the recoveries of contaminants of emerging concern in solid phases and waters were below 70 percent. Recoveries in biosolids were complicated by the following: extremely complex aqueous matrix with a few percent solids by weight, difficulty of collecting true replicates of a complex matrix, presence of interferents (contributing to artificially high recoveries), and relatively small differences between concentrations in the environmental and spiked replicates. Recoveries in water samples were complicated by similar issues.

Finally, several constituents were detected in various surface-water and groundwater blanks, although only nitrate in one surface-water sample and bisphenol A in one groundwater sample were present in concentrations greater than three times the reporting level. In the case of nitrate, it was only one of many blanks, which would be consistent with infrequent contamination. In the case of bisphenol A, it was 
Table 9. Constituents with high variability, low or incorrectly high recovery, and high bias in all media as determined by qualitycontrol samples.

[>, greater than; E. coli, echerichia coli; N/A, not applicable]

\begin{tabular}{|c|c|c|c|c|}
\hline Metric & Biosolids & Soils & Surface water & Ground water \\
\hline $\begin{array}{l}\text { Variability }>30 \text { percent } \\
\text { (Constituents with relatively large } \\
\text { absolute concentration differences } \\
\text { are shown in bold) }\end{array}$ & $\begin{array}{l}\text { mercury } \\
\text { cotinine } \\
\text { carbamazepine } \\
\text { diphenhydramine } \\
\text { citalopram } \\
\text { sertraline } \\
\text { caffeine } \\
\text { fluoxetine } \\
\text { HEM } \\
\text { SGT-HEM }\end{array}$ & chromium & $\begin{array}{l}\text { ammonia } \\
\boldsymbol{E} \text {. coli } \\
\text { fecal coliform } \\
\text { aluminim } \\
\text { copper } \\
\text { iron } \\
\text { managanese }\end{array}$ & $\begin{array}{l}\text { fluoride } \\
\text { iron } \\
\text { fecal coliform } \\
\text { bisphenol A }\end{array}$ \\
\hline $\begin{array}{l}\text { Recovery less than } 70 \text { percent or more } \\
\text { than } 130 \text { percent }\end{array}$ & $\begin{array}{l}\text { aluminum } \\
\text { manganese } \\
\text { mercury } \\
52 \text { of } 57 \text { wastewater } \\
\text { compounds } \\
13 \text { of } 20 \text { hormones } \\
27 \text { of } 28 \text { pharmaceuticals }\end{array}$ & $\begin{array}{l}\text { antimony } \\
\text { SGT-HEM }\end{array}$ & $\begin{array}{l}41 \text { of } 69 \text { wastewater } \\
\text { compounds } \\
\text { cholesterol } \\
\text { progesterone } \\
\text { equilin } \\
13 \text { of } 14 \text { pharmaceuticals }\end{array}$ & \\
\hline $\begin{array}{l}\text { Detections in blanks } \\
\text { (Constituents with detections }>\mathbf{3} \text { times } \\
\text { the reporting level are shown in } \\
\text { bold) }\end{array}$ & $\mathrm{N} / \mathrm{A}$ & $\mathrm{N} / \mathrm{A}$ & $\begin{array}{l}\text { nitrate } \\
\text { ammonia } \\
\text { iron } \\
\text { calcium } \\
\text { magnesium } \\
\text { potassium } \\
\text { sodium } \\
\text { total dissolved solids } \\
\text { N,N-Diethyl-m-toluamide } \\
\quad \text { (DEET) }\end{array}$ & $\begin{array}{l}\text { iron } \\
\text { fecal coliform } \\
\text { bisphenol A } \\
\text { N,N-Diethyl-m-toluamide } \\
\quad \text { (DEET) }\end{array}$ \\
\hline
\end{tabular}

one of two blanks and so probably should be considered in any discussion.

\section{Precipitation}

The rain gages were checked to assure they remained properly calibrated twice during the data-collection period (February 2011 to June 2013). These calibration checks were done in accordance with USGS Office of Surface Water Technical Memorandum No. 2006.01 (U.S. Geological Survey, 2005). On average, six visits were made to the sites annually to check for obstructions and general cleanliness of the rain gage. The tipping mechanism was inspected and cleaned, if required, to ensure accurate measurements. If obstructions to the bucket funnel or impedance to the tipping mechanisms were found, the data were closely scrutinized and removed, as needed, from the USGS database. Periods of frozen precipitation and subsequent days of associated melt were removed from the dataset. All data were processed, checked, and reviewed in accordance with USGS Office of Surface Water Technical Memorandum No. 2006.01 to ensure that proper QA/QC guidelines were followed for each site.

\section{Discharge}

The USGS operated and maintained continuous record streamflow gaging stations at the three surface-water monitoring sites during this study. Stage and streamflow data were collected, processed, and analyzed in accordance with the quality-assurance plan for surface-water activities of the USGS South Atlantic Water Science Center (Rantz and others, 1982; Mueller and others, 2013; U.S. Geological Survey, 2010b). Final results were entered into the USGS NWIS database. Data for study streamgaging sites are available online at http://waterdata.usgs.gov/nc/nwis/. 


\section{Statistical Analysis of Water-Quality Data}

The nonparametric Mann-Whitney test (Mann and Whitney, 1947) was used to determine whether two independent populations of groundwater-quality data (winter/ spring versus summer/fall) were statistically different at the 95 percent confidence level (p-value less than 0.05). Note that the lack of significance does not mean that, for a given constituent, concentrations do not differ between the seasons; it only means that a significant difference in medians between the seasons, if any, was not large enough to be detected with the given sample size collected over less than 2 years. The ANOVA (for normally distributed data, (Helsel and Hirsch, 1992)) and Kruskal-Wallis (for nonparametric data, (Kruskal and Wallis, 1952)) statistical tests were used to determine whether groundwater constituent concentrations among the six monitoring sites were statistically different. If the ANOVA or Kruskal-Wallis tests indicated that the medians of the populations were statistically different, a subsequent Tukey-Kramer multiple comparison test (Tukey, 1977) was used to determine which populations were different.

Statistical comparison testing was also conducted to evaluate if there were statistically significant differences in surface-water concentrations of nutrients, bacteria, and selected ions between baseflow and stormwater runoff conditions at each monitoring site, for winter/spring and summer/fall seasons, and among the three monitoring sites. The nonparametric Mann-Whitney test (Mann and Whitney, 1947) was used to determine whether two independent populations of surface-water quality data (baseflow versus storm runoff and winter/spring versus summer/fall) were statistically different at the 95 percent confidence level (p-value less than 0.05). Note that the lack of significance does not mean that, for a given constituent, concentrations do not differ between baseflow and stormwater runoff or between the seasons; it only means that a significant difference in medians was not large enough to be detected with the given sample size, which was relatively small for baseflow ion data and samples collected in the summer/fall season. The ANOVA (for normally distributed data, (Helsel and Hirsch, 1992)) and Kruskal-Wallis (for nonparametric data, (Kruskal and Wallis, 1952)) statistical tests were used to determine whether surfacewater constituent concentrations among the three monitoring sites were statistically different. If the ANOVA or Kruskal-Wallis tests indicated that the medians of the populations were statistically different, a subsequent Tukey-Kramer multiple comparison test (Tukey, 1977) was used to determine which populations were different.

\section{Surface-Water Load Computations}

Surface-water load computations for selected constituents were performed for the two surface-water monitoring sites (upstream site CO-SW1 and downstream site CO-SW5) at the Collins Creek biosolids land application site and for the Cane Creek background surface-water monitoring site (CA-SW1).
At each site, the analytical results of the discrete surface-water samples (baseflow and stormwater runoff) were combined with the compiled mean daily streamflow data for estimating stream loads of nutrients (nitrate, total organic N, TN, and TP), bacteria (E. coli and fecal coliform), and major ions (calcium, magnesium, potassium, sodium, and chloride) for the period March 2011 through May 2013. The water-quality and instantaneous streamflow datasets (for model calibrations) and the mean-daily streamflow datasets (for model predictions) used for computing stream constituent loads for sites CO-SW1, CO-SW5, and CA-SW1 are provided in appendix tables 4-1, 4-2, and 4-3, respectively. The stream load estimates were computed using the statistical program LOADEST (Runkel and others, 2004). The specific software used was S-LOADEST, which is a USGS plug-in version of LOADEST within the S-PLUS software suite (by TIBCO Software Inc., ver. 6.1), a PC-based statistical software package. The S-LOADEST software and documentation are publicly available and can be downloaded from the USGS Web site at $h$ ttp://water.usgs.gov/software/loadest/.

The following describes steps taken to prepare the water-quality and streamflow data for subsequent use in developing the analytical data calibration files and streamflow prediction files for the S-LOADEST program. The analytical data calibration files developed for modeling loads at each site (appendix tables 4-1, 4-2, and 4-3) include the USGS station number, sample dates and times, the instantaneous value of streamflow at the time samples were collected, and laboratory remark codes and concentrations for the individual nutrient, bacteria, and major ion constituents. As previously mentioned, any censoring associated with sample concentrations of organic $\mathrm{N}$ and TN was dropped from the calibration files for the purpose of estimating stream loads for organic $\mathrm{N}$ and $\mathrm{TN}$.

The streamflow prediction files for each study site include daily mean streamflow values that were retrieved through the USGS NWIS database. The compiled streamflow data were used in combination with the constituent calibration data for predicting stream loads with the S-LOADEST program. Various periods of dry climatic conditions in the small watersheds of the Collins Creek monitoring sites resulted in periods of no streamflow at the sites. In these cases, the retrieved daily mean values of streamflow (in cubic feet per second) were reported as zero. These values are problematic because the LOADEST computations rely on log-transformed streamflow values and will not function when the streamflow input file contains values of zero. For this reason, dates with reported daily mean values of zero streamflow were arbitrarily assigned a value of 0.001 cubic foot per second $\left(\mathrm{ft}^{3} / \mathrm{s}\right)$ for the streamflow prediction files in order to permit computation of annual, seasonal, and monthly loads. This extremely low arbitrary value is an order of magnitude lower than the minimum measureable daily mean streamflow and, therefore, would have negligible effects on the estimated loads. Any dates where $0.001 \mathrm{ft}^{3} / \mathrm{s}$ was substituted for zero for the mean-daily streamflow are denoted within the site's prediction files (appendix tables 4-1, 4-2, and 4-3).

The S-LOADEST program was used to estimate total, annual, monthly, seasonal, and daily constituent loads (including 
nitrate plus nitrite $\mathrm{N}$, total organic N, TN, TP, E. coli, fecal coliform, calcium, magnesium, potassium, sodium, and chloride) at each site for the period March 2011 through May 2013. Seasonal loads were computed for four periods, including March through May, June through August, September through November, and December through February. The load estimates for each constituent were obtained using the best combination of seven variables in a log-linear regression model selected with ranking by the Akaike information criterion (Akaike, 1974; Cohn and others, 1989; Gilroy and others, 1990; Cohn and others, 1992). The S-LOADEST has nine potential models that are evaluated by the Akaike information criterion. The full seven-variable model is:

$$
\begin{aligned}
& \ln \mathrm{L}=\mathrm{a}_{0}+\mathrm{a}_{1} \ln \mathrm{Q}+\mathrm{a}_{2}(\ln \mathrm{Q})^{2}+\mathrm{a}_{3} \mathrm{t}+\mathrm{a}_{4} \mathrm{t}^{2}+\mathrm{a}_{5} \sin (2 \pi \mathrm{t}) \\
& +\mathrm{a}_{6} \cos (2 \pi \mathrm{t})+e
\end{aligned}
$$

where

In is natural logarithm function;

$\mathrm{L}$ is load, in pounds;

$\mathrm{a}_{0}, \mathrm{a}_{1}, \mathrm{a}_{2}, \mathrm{a}_{3}, \mathrm{a}_{4}, \mathrm{a}_{5}, \mathrm{a}_{6}$ are coefficients of the regression model;

Q is instantaneous discharge at time of sampling, in cubic feet per second;

$\mathrm{t}$ is time, in decimal years;

$\sin$ is sine function;

$\pi$ is 3.14169;

$\cos$ is cosine function; and

$e$ is model error term.

The other eight models have one or more of the variables above omitted based on the relevance in the model performance as determined by the Akaike information criterion.

The discharge terms $\left(\mathrm{a}_{1} \ln \mathrm{Q}\right.$ and $\left.\mathrm{a}_{2}(\ln \mathrm{Q})^{2}\right)$ in the model address variability in concentration resulting from discharge variability. The time terms $\left(a_{3} t\right.$ and $\left.a_{4} t^{2}\right)$ adjust for variability resulting from a linear time trend in concentration, and the sine and cosine terms adjust for seasonal variability in concentration. Bias generated in the estimated load when the load is transformed from log to linear units was corrected using the minimum variance unbiased estimator correction (Bradu and Mundlak, 1970). Censored data were statistically adjusted using the adjusted maximum likelihood estimator (Cohn and others, 1989; Cohn, 2005).

The S-LOADEST model equations and program output results generated for each constituent and time period are compiled in appendix tables 4-4, 4-5, and 4-6 for sites CO-SW1, CO-SW5, and CA-SW1, respectively. Output results include, regression model used, daily mean flux [in pounds per day], variance of the flux, the lower and upper 95 percent confidence intervals of the flux, the standard error of prediction [SEP] of the flux, the number of days in the period, and the total estimated load for the period [in pounds]. The SEP for the load estimates (Runkel and others, 2004) incorporates both variability attributed to the model calibration (parameter uncertainty) and unexplained variability about the model (random error). The SEP indicates how closely estimated loads correspond to actual loads and is used to develop the 95 percent confidence intervals for each load estimate.

As part of data evaluations in this report, the computed constituent loads, in pounds per day, for each site were normalized by drainage area to compute total, annual, seasonal, and monthly yields of nitrate, total organic $\mathrm{N}, \mathrm{TN}$, TP, E. coli, fecal coliform, calcium, magnesium, potassium, sodium, and chloride, in pounds per square mile. It should be noted that the estimated nitrate loads for the study sites are actually based on the sample concentrations of nitrate plus nitrite as $\mathrm{N}$; however, because nitrite typically represents a small fraction of the overall nitrate plus nitrite as $\mathrm{N}$ concentration, the subsequent loads computed with S-LOADEST are presented and discussed as nitrate as N. The stream load and yield data were used to explore potential differences in surface-water quality resulting from the presence or absence of land-applied biosolids at the study sites.

\section{Effect of Land-Applied Biosolids on Surface-Water and Groundwater Quality}

A better understanding of the quantity and characteristics of nutrients, bacteria, metals, and contaminants of emerging concern that may be transported from biosolids fields to groundwater and surface-water resources is needed to provide the framework for developing guidance on effective techniques for monitoring and enforcing regulation of permitted biosolids land-application sites. Although regulations are in place, there is little scientific information available to quantify the actual delivery of pollutants, such as nutrients, bacteria, metals, and contaminants of emerging concern, from biosolids application fields to groundwater and surface water and to determine if the current requirements are protective of water resources and human health. Therefore, the subsequent sections focus on quantifying the concentrations and loadings of nutrients, metals, and bacteria from representative agricultural fields with and without land-applied municipal biosolids to groundwater and surface water.

\section{Soil and Biosolids}

The following sections summarize analytical results of biosolids, pre- and post-land application samples from three OWASA-owned agricultural fields (AF 11-2, AF 11-4, and AF 11-6) and soil samples from a background agricultural field (BF1) onto which biosolids have never been applied (table 1). The information will provide the framework for characterizing the effect of agricultural watersheds with and without land-applied biosolids on water quality. 


\section{Summary and Comparisons of Constituent Concentrations}

Biosolids application dates and volumes are listed for agricultural fields AF 11-2, AF 11-4, and AF-11-6 for 2010-13 (table 10). Biosolids were sampled (bold red text in table 10) in 2011 and 2012 although applications from the previous and following year are included for comparison. The two classes of biosolids, A and B, are distinguished by levels of pathogens that were not directly measured in this study (see Introduction section). Class A biosolids have higher pathogen removal criteria than class B biosolids, and as a result, class B biosolids were given larger setbacks from surface-water features and were applied to smaller areas for two of the OWASA fields (AF 11-2 and AF 11-6). Compared to 2010, total land-applied volumes in 2011 and 2012 were lower in fields AF 11-2 and AF 11-4 but were higher in field AF 11-6, respectively (fig. 5). Of the biosolids application events that were sampled as part of this study, the total volume applied ranged from a minimum of 17,200 gallons (October 17, 2011) on fields AF 11-2 and AF 11-4 to a maximum of 81,700 gallons (July 6, 2012) on field AF 11-6.

There were no exceedances of the 10 elements with designated EPA ceiling concentrations in any biosolids or soil samples (table 11). Measured concentrations of these elements along with those of total Kjeldahl nitrogen (TKN), total phosphorus (TP), fecal coliform, and E. coli are shown for the entire study period for each of the three application fields and the background field (fig. 6). The concentrations of most constituents through three applications of biosolids stayed relatively uniform over time within and among fields (table 11; fig. 6). The exceptions are the fecal coliform and $E$. coli concentrations that fluctuated orders of magnitude in all fields, including the background field. That degree of variability indicates that factors other than biosolids application may be influencing the fecal indicator bacterial levels at these sites. A study of biosolids application to soils in Colorado similarly found no measureable effect of biosolids application on measured metal and nutrient concentrations in soil (Yager and others, 2004). The biosolids application rate in the Colorado study (1.14 tons dry weight per acre) was comparable to the high end of the application rates in the current study (median of 0.40 and range of $0.14-1.9$ tons dry weight per acre).

Thus, the hypothesis might be that repeated application over a much longer time frame could eventually result in measurable accumulation of metals and nutrients in soil over time. Given that biosolids have been applied to fields AF 11-2, AF 11-4, and AF 11-6 for more than 25 years, this hypothesis was evaluated by comparing the median of the pre- and post-application soil concentrations of the 10 constituents with ceiling concentrations plus TKN, TP, and bacteria in each application field to the median of the soil concentrations in the background field (fig. 7). Compared to the background field, the biosolids land-application fields had elevated concentrations of copper, mercury, molybdenum,
TKN, and TP. The background field had the highest median concentration of cadmium, lead, selenium, and fecal coliform. The median concentration of five constituents (arsenic, chromium, nickel, zinc, and E. coli) overlapped between the application fields and the background field.

A cumulative loading to the soils that can be attributed to application of biosolids was calculated for the five constituents (copper, molybdenum, TKN, TP, and mercury) that had elevated median concentrations with respect to the background site. These calculations were used to determine if the biosolids applications over some 25 years (approximately twice per year) could account for the higher concentrations (table 12). Multiplying the median constituent concentrations of the five constituents individually in the biosolids samples by the median dry mass of applied biosolids, assuming two applications a year for 25 years (50 applications total), yielded a total mass of each constituent in biosolids added to the soil. The total mass applied for each of the five constituents was divided into the calculated dry mass in the soil sample core volume (463.1 grams), yielding a theoretical concentration $\left(\mathrm{C}_{\text {theor }}\right)$ of the five constituents that was added to the fields from just the biosolids applications. It is assumed that all these applications were contained in the top 6 inches (depth of the soil core) of soil. The median measured concentrations for the five constituents from soil samples from the background field was subtracted from the median measured concentrations for soil samples from the biosolids application fields to yield the concentration that was apparently added to the soil core volume $\left(\mathrm{C}_{\text {meas }}\right)$. The theoretical contribution of land-applied biosolids to measured soil concentrations is presented in table 12 as a percentage of the measured contribution from the biosolids for each of the five constituents $\left(\mathrm{C}_{\text {theor\% }}\right)$, using the following equation:

$$
\mathrm{C}_{\text {theor\% }}=\left(\mathrm{C}_{\text {theor }} / \mathrm{C}_{\text {meas }}\right) * 100
$$

This analysis revealed that there was more than enough mass of molybdenum and TKN to account for the elevated concentrations in the application fields. If the application rates, weight percent solids, and concentrations measured in 2011 and 2012 were representative of all biosolids applications to those fields, there must be some mechanism to account for the loss of these two constituents in the application fields over decades. Both molybdenum and nitrogen may be lost through crop uptake, solubilization, and (or) subsequent transport, and nitrogen may also be denitrified. For copper and TP, the calculated mass additions of these constituents in the biosolids could account for between half and all the elevated concentrations observed. For some fields, there seems to be another source of these elements besides biosolids, though biosolids are considered to be a major source on the basis of comparisons with concentrations from the background field. Finally, for mercury, analytical performance issues limit discussion, but there is some indication that biosolids might not be the major source of this element to the application fields. 
Table 10. Summary of biosolids land-application dates and volumes for agricultural fields AF 11-2, AF 11-4, and AF 11-6 in Orange County, North Carolina, 2010-13.

[Biosolids sampled indicated in bold red; cell shaded in blue represent application of Class B biosolids, all other data represent application of Class A biosolids]

\begin{tabular}{|c|c|c|c|}
\hline \multirow[b]{2}{*}{ Biosolids land-application date } & \multicolumn{3}{|c|}{$\begin{array}{c}\text { Biosolids land-application volume, } \\
\text { in gallons }\end{array}$} \\
\hline & $\begin{array}{c}\text { Field } \\
\text { AF 11-2 }\end{array}$ & $\begin{array}{c}\text { Field } \\
\text { AF 11-4 }\end{array}$ & $\begin{array}{c}\text { Field } \\
\text { AF 11-6 }\end{array}$ \\
\hline \multicolumn{4}{|c|}{2010} \\
\hline Tuesday, March 23, 2010 & 34,400 & 0 & 0 \\
\hline Wednesday, March 24, 2010 & 30,100 & 43,000 & 0 \\
\hline Thursday, March 25, 2010 & 0 & 43,000 & 0 \\
\hline Wednesday, March 31, 2010 & 77,400 & 0 & 0 \\
\hline Monday, April 05, 2010 & 47,300 & 0 & 0 \\
\hline Tuesday, April 06, 2010 & 43,000 & 25,800 & 0 \\
\hline Wednesday, April 07, 2010 & 0 & 73,100 & 0 \\
\hline Thursday, April 08, 2010 & 0 & 60,200 & 0 \\
\hline Tuesday, August 24, 2010 & 51,600 & 0 & 0 \\
\hline Wednesday, August 25, 2010 & 38,700 & 0 & 0 \\
\hline Thursday, August 26, 2010 & 0 & 0 & 25,800 \\
\hline Friday, August 27, 2010 & 0 & 0 & 30,100 \\
\hline Monday, August 30, 2010 & 0 & 0 & 86,000 \\
\hline Total land-applied volume in 2010 & 322,500 & 245,100 & 141,900 \\
\hline \multicolumn{4}{|c|}{2011} \\
\hline Wednesday, April 13, 2011 & 30,100 & 0 & 0 \\
\hline Thursday, April 14, 2011 & 30,100 & 0 & 0 \\
\hline Thursday, April 21, 2011 & 0 & 17,200 & 0 \\
\hline Tuesday, April 26, 2011 & 0 & 34,400 & 0 \\
\hline Wednesday, April 27, 2011 & 0 & 21,500 & 0 \\
\hline Saturday, July 02, 2011 & 0 & 0 & 43,000 \\
\hline Tuesday, July 05, 2011 & 0 & 0 & 51,600 \\
\hline Wednesday, July 06, 2011 & 0 & 0 & 43,000 \\
\hline Monday, August 29, 2011 & 0 & 0 & 73,100 \\
\hline Wednesday, August 31, 2011 & 0 & 0 & 25,800 \\
\hline Tuesday, September 13, 2011 & 0 & 47,300 & 0 \\
\hline Monday, October 17, 2011 & 17,200 & 17,200 & 0 \\
\hline Friday, October 21, 2011 & 55,900 & 0 & 0 \\
\hline Total land-applied volume in 2011 & 133,300 & 137,600 & 236,500 \\
\hline
\end{tabular}


Table 10. Summary of biosolids land-application dates and volumes for agricultural fields AF 11-2, AF 11-4, and AF 11-6 in Orange County, North Carolina, 2010-13.Continued

[Biosolids sampled indicated in bold red; cell shaded in blue represent application of Class B biosolids, all other data represent application of Class A biosolids]

\begin{tabular}{|c|c|c|c|}
\hline \multirow[b]{2}{*}{ Biosolids land-application date } & \multicolumn{3}{|c|}{$\begin{array}{l}\text { Biosolids land-application volume, } \\
\text { in gallons }\end{array}$} \\
\hline & $\begin{array}{l}\text { Field } \\
\text { AF 11-2 }\end{array}$ & $\begin{array}{l}\text { Field } \\
\text { AF 11-4 }\end{array}$ & $\begin{array}{l}\text { Field } \\
\text { AF 11-6 }\end{array}$ \\
\hline \multicolumn{4}{|c|}{2012} \\
\hline Tuesday, March 20, 2012 & 0 & 25,800 & 0 \\
\hline Wednesday, March 28, 2012 & 0 & 68,800 & 0 \\
\hline Thursday, March 29, 2012 & 77,400 & 0 & 0 \\
\hline Friday, March 30, 2012 & 25,800 & 0 & 0 \\
\hline Thursday, June 14, 2012 & 43,000 & 0 & 0 \\
\hline Thursday, July 05, 2012 & 0 & 0 & 43,000 \\
\hline Friday, July 06, 2012 & 0 & 0 & 81,700 \\
\hline Wednesday, October 31, 2012 & 0 & 0 & 77,400 \\
\hline Thursday, November 01, 2012 & 0 & 0 & 64,500 \\
\hline Tuesday, November 13, 2012 & 0 & 77,400 & 0 \\
\hline Wednesday, November 14, 2012 & 0 & 30,100 & 0 \\
\hline Saturday, December 01, 2012 & 30,100 & 0 & 0 \\
\hline Sunday, December 02, 2012 & 51,600 & 0 & 0 \\
\hline Total land-applied volume in 2012 & 227,900 & 202,100 & 266,600 \\
\hline \multicolumn{4}{|c|}{2013} \\
\hline Thursday, April 11, 2013 & 0 & 64,500 & 0 \\
\hline Wednesday, April 24, 2013 & 90,300 & 30,100 & 0 \\
\hline Thursday, April 25, 2013 & 21,500 & 0 & 0 \\
\hline Tuesday, July 23, 2013 & 0 & 0 & 39,000 \\
\hline Wednesday, July 24, 2013 & 0 & 0 & 78,000 \\
\hline Thursday, July 25, 2013 & 0 & 0 & 91,000 \\
\hline Sunday, August 04, 2013 & 0 & 64,500 & 0 \\
\hline Saturday, September 14, 2013 & 0 & 25,800 & 0 \\
\hline Sunday, September 15, 2013 & 21,500 & 0 & 0 \\
\hline Tuesday, September 17, 2013 & 68,800 & 0 & 0 \\
\hline Thursday, October 03, 2013 & 0 & 0 & 43,000 \\
\hline Friday, October 04, 2013 & 0 & 0 & 43,000 \\
\hline Total land-applied volume in 2013 & 202,100 & 184,900 & 294,000 \\
\hline
\end{tabular}




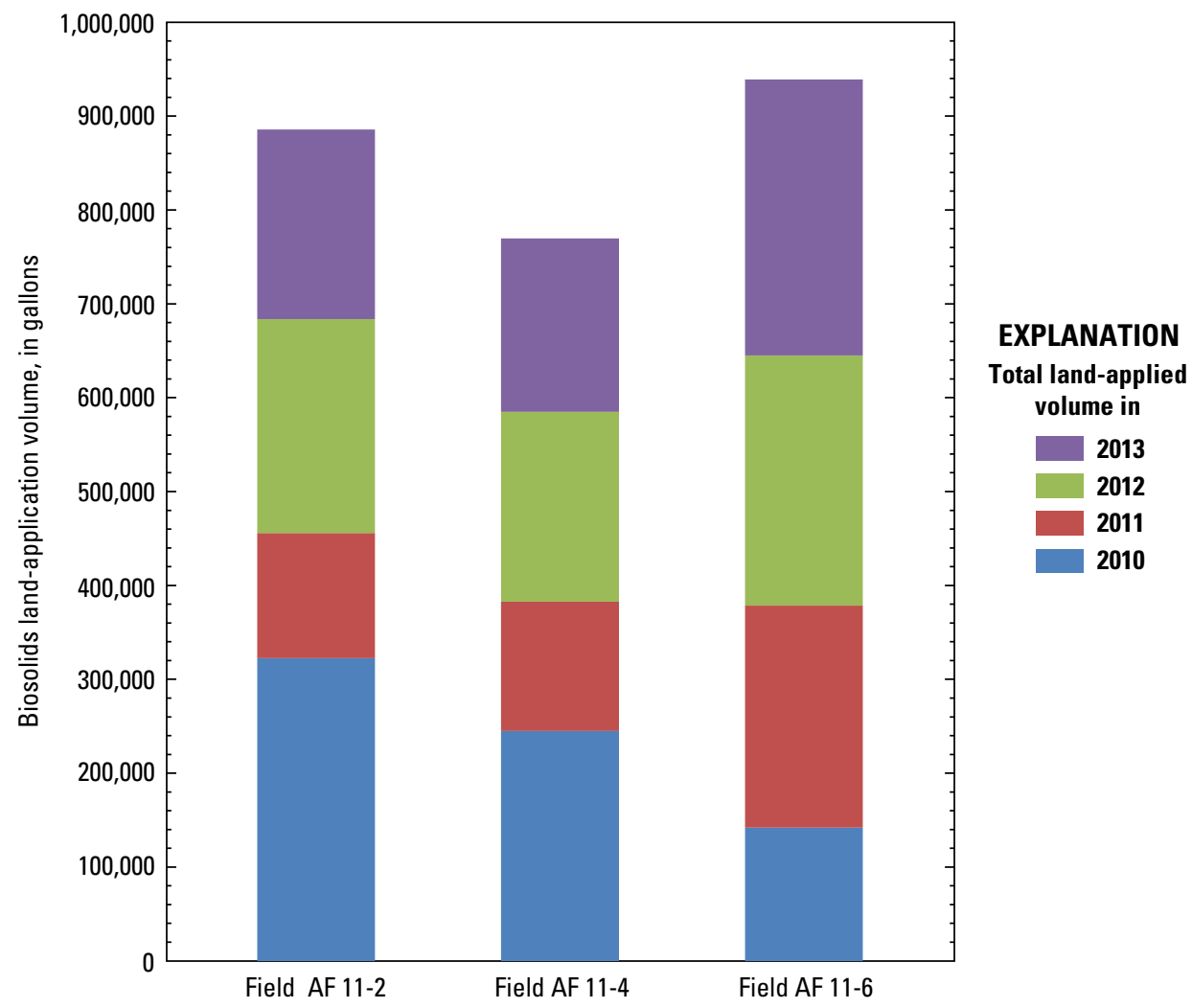

Figure 5. Biosolids land-application volumes for 2010-13 for agricultural fields AF 11-2, AF 11-4, and AF 11-6 in Orange County, North Carolina. 
Table 11. Concentrations of U.S. Environmental Protection Agency-regulated constituents in land-applied biosolids, and total Kjeldahl nitrogen, total phosphorus, Escherichia coli, and fecal coliform bacteria in biosolids and pre- and post-biosolids application soil samples collected from agricultural fields (A) AF 11-2, (B) AF 11-4, (C) AF 11-6, and (D) the background field BF1 in Orange County, North Carolina.

[All chemical results reported in milligrams per kilogram; all bacteria results reported in most probable number per gram; TKN, total Kjeldahl nitrogen; TP, total phosphorus; ND, not determined]

A. Biosolids and soil concentrations, in milligrams per kilogram, for agriculture field AF 11-2

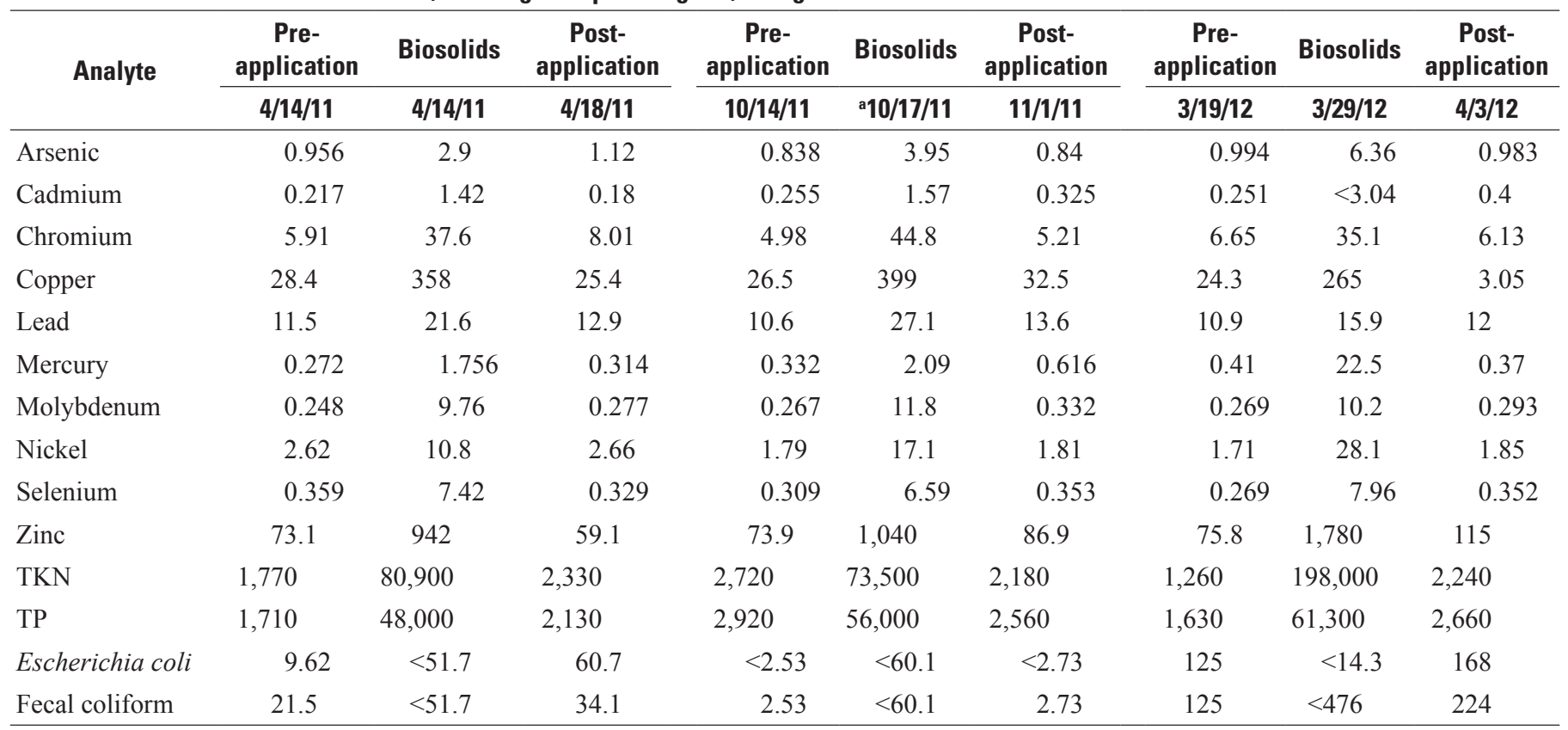

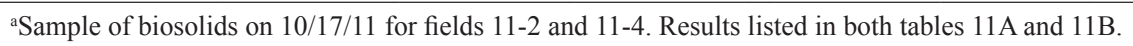

B. Biosolids and soil concentrations, in milligrams per kilogram, for agriculture field AF 11-4

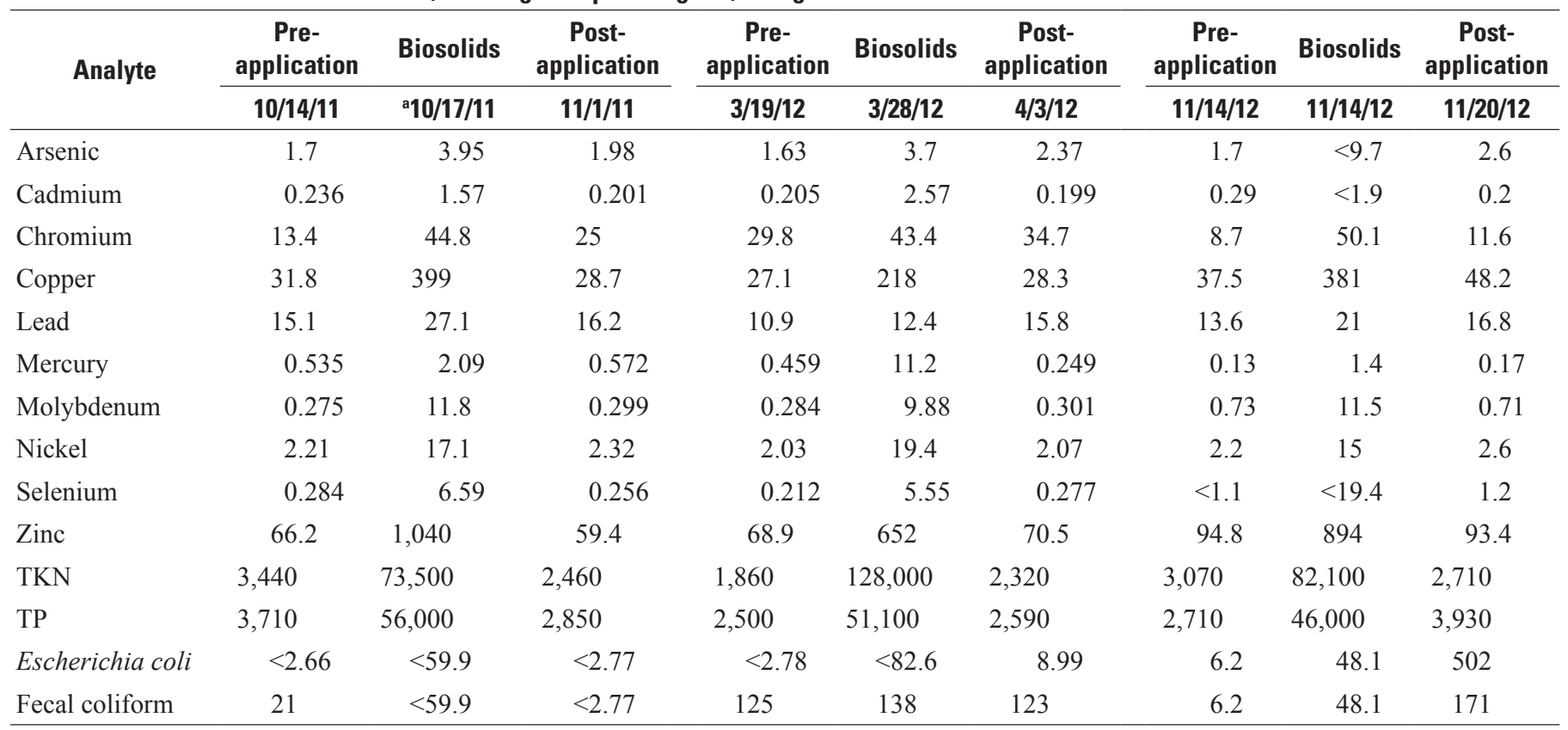

a Sample of biosolids on 10/17/11 for fields 11-2 and 11-4. Results listed in both tables 11A and 11B. 
Table 11. Concentrations of U.S. Environmental Protection Agency-regulated constituents in land-applied biosolids, and total Kjeldahl nitrogen, total phosphorus, Escherichia coli, and fecal coliform bacteria in biosolids and pre- and post-biosolids application soil samples collected from agricultural fields (A) AF 11-2, (B) AF 11-4, (C) AF 11-6, and (D) the background field BF1 in Orange County, North Carolina.-Continued

[All chemical results reported in milligrams per kilogram; all bacteria results reported in most probable number per gram; TKN, total Kjeldahl nitrogen; TP, total phosphorus; ND, not determined]

C. Biosolids and soil concentrations, in milligrams per kilogram, for agriculture field AF 11-6

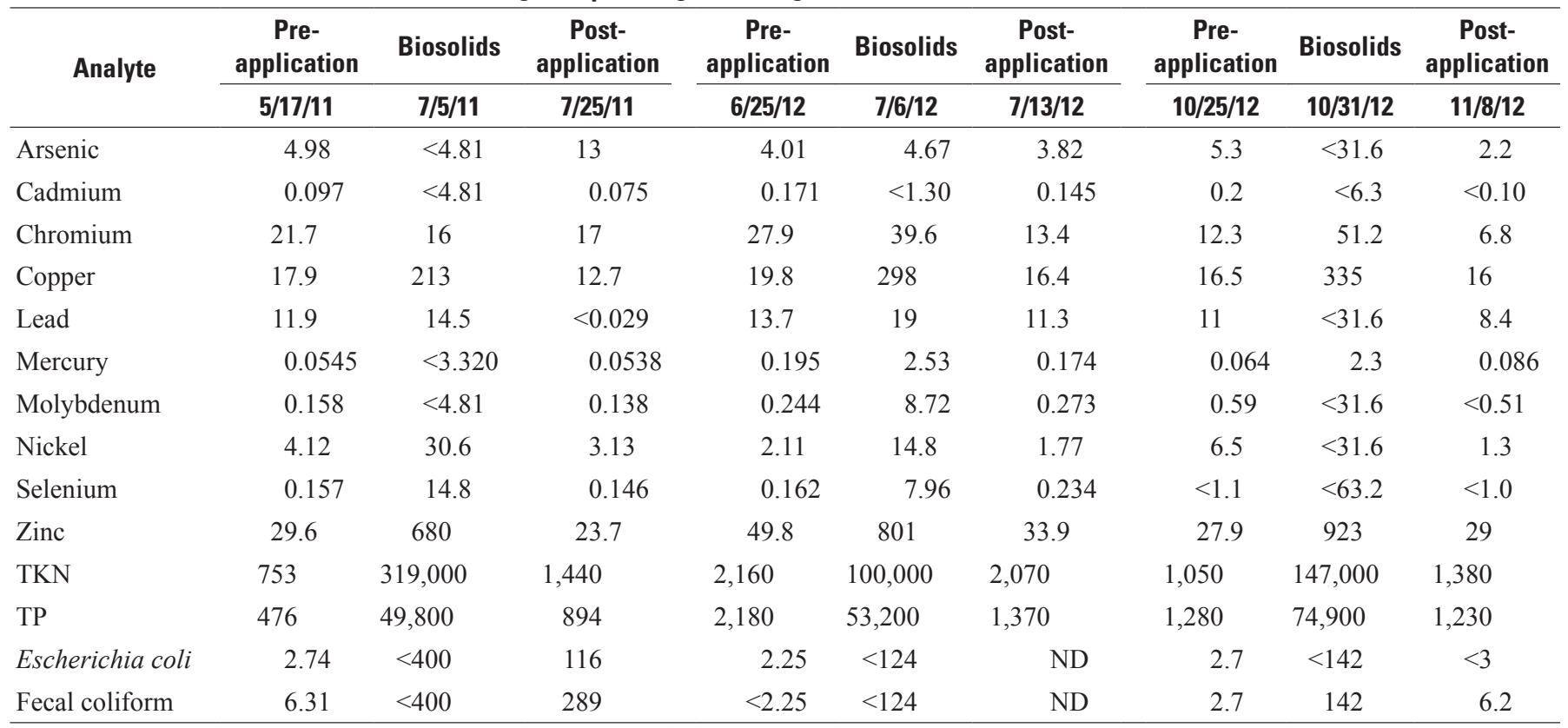

D. Soil concentrations, in milligrams per kilogram, for background field BF1

\begin{tabular}{lcccc}
\hline \multicolumn{1}{c}{ Analyte } & $\mathbf{1 2 / 2 2 / 1 1}$ & $\mathbf{4 / 9 / 1 2}$ & $\mathbf{8 / 1 / 1 2}$ & $\mathbf{1 1 / 8 / 1 2}$ \\
\hline Arsenic & 1.51 & 2.3 & 1.6 & 1.8 \\
Cadmium & 0.125 & 1.2 & 1.0 & 0.25 \\
Chromium & 14.8 & 17.3 & 15.1 & 15.4 \\
Copper & 9.49 & 9.2 & 8.7 & 5.6 \\
Lead & 20 & 20.7 & 23.3 & 21.1 \\
Mercury & 0.0505 & 0.016 & 0.017 & 0.015 \\
Molybdenum & 0.171 & $<0.54$ & $\mathrm{ND}$ & $<0.56$ \\
Nickel & 2.95 & 1.9 & 1.9 & 1.5 \\
Selenium & 0.324 & 1.2 & $\mathrm{ND}$ & $<1.1$ \\
Zinc & 26.4 & 33.8 & 37.5 & 28 \\
TKN & 858 & 1,370 & 1,510 & 1,040 \\
TP & 334 & 227 & 242 & 232 \\
Escherichia coli & $<2.27$ & 3.98 & $<2.6$ & 116 \\
Fecal coliform & 922 & 10.9 & $<2.6$ & 155 \\
\hline
\end{tabular}



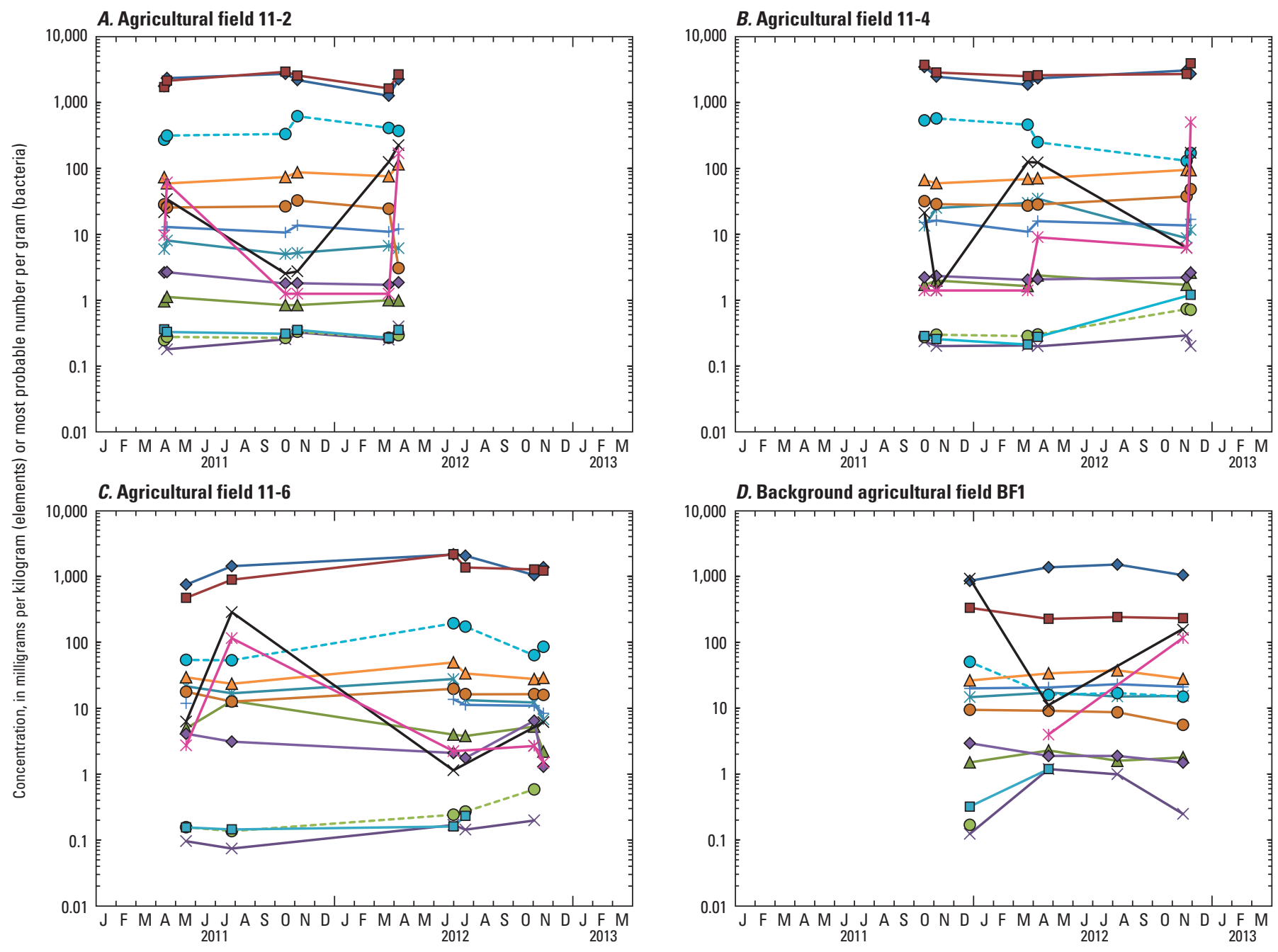

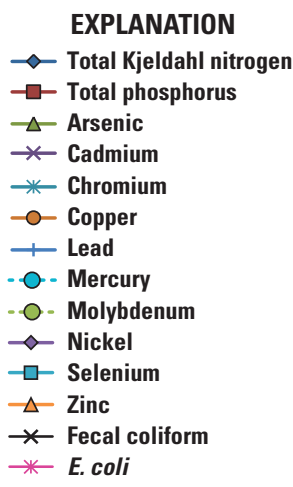

Figure 6. Time series of concentrations of elements with U.S. Environmental Protection Agency ceiling concentrations for land-applied biosolids plus total Kjeldahl nitrogen (TKN), total phosphorus (TP), and Escherichia coli, and fecal coliform in biosolids land-application fields and the background field in Orange County, North Carolina. 


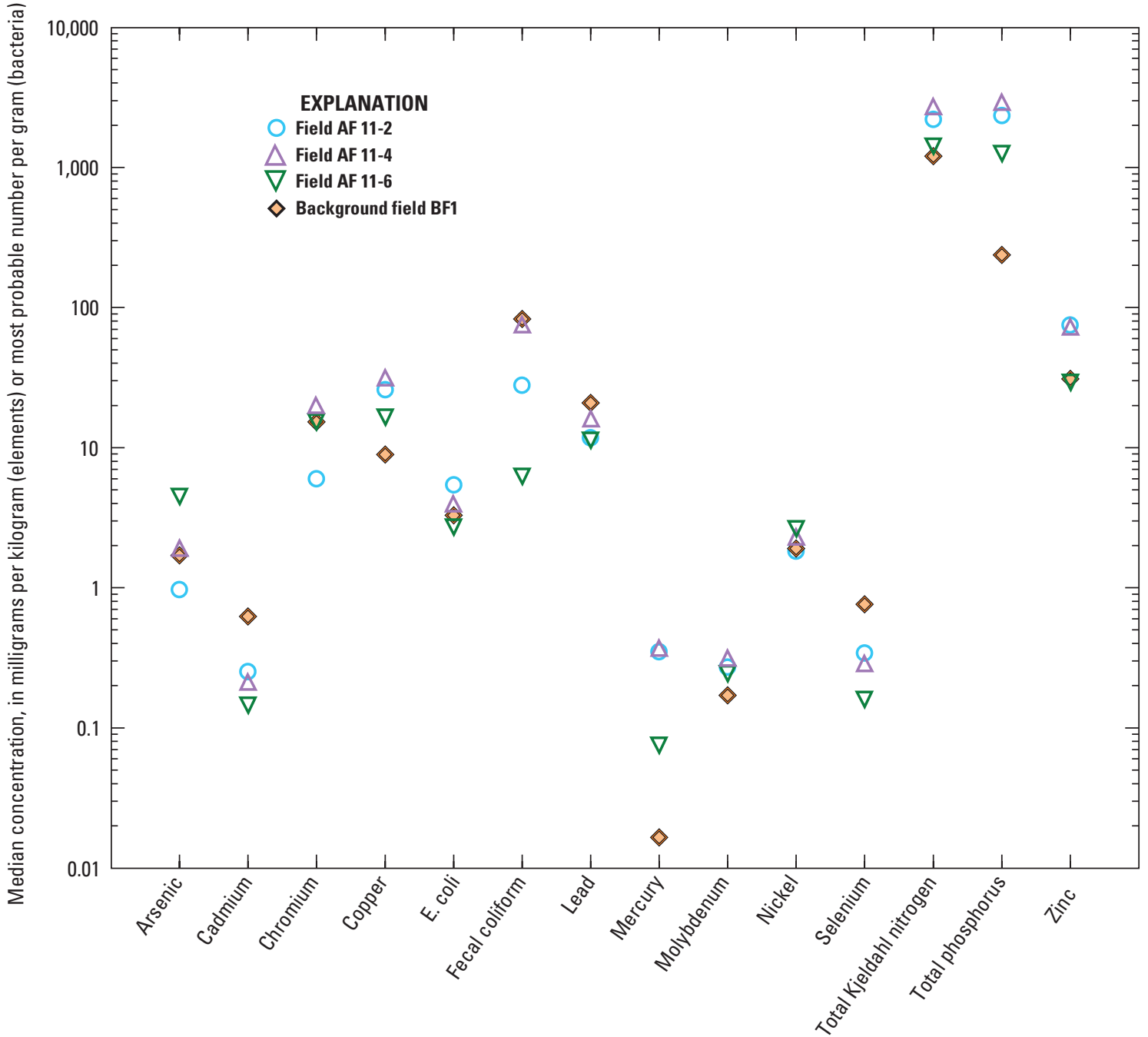

Figure 7. Median concentrations of elements with U.S. Environmental Protection Agency ceiling concentrations for land-applied biosolids plus total Kjeldahl nitrogen (TKN), total phosphorus (TP), and Escherichia coli, and fecal coliform in biosolids land-application fields and the background field in Orange County, North Carolina. 
Table 12. Percentage of elemental concentration in biosolids application fields that can be accounted for as biosolids addition.

[>, greater than]

\begin{tabular}{lccc}
\hline \multirow{2}{*}{ Constituent } & \multicolumn{3}{c}{$\begin{array}{c}\text { Potential contribution from biosolids } \\
\text { (percent) }\end{array}$} \\
\cline { 2 - 4 } & AF 11-2 & AF 11-4 & AF 11-6 \\
\hline Copper & 74 & 36 & 51 \\
Molybdenum & $>100$ & $>100$ & $>100$ \\
Total Kjeldahl nitrogen & $>100$ & $>100$ & $>100$ \\
Total phosphorus & 97 & 49 & 63 \\
Mercury* & 24 & 14 & 43 \\
\hline
\end{tabular}

*Potentially large errors.

The potential short-term effect of land application of biosolids to agricultural fields was evaluated using both the chemical concentration and dry mass of the biosolids samples in relation to that of the (pre-application) soil onto which the biosolids were applied (table 11). The median concentration ratio of the 10 elements with EPA-designated ceiling concentrations in biosolids compared to the soils ranged from 2 for lead to approximately 37 for molybdenum. The median concentration ratios of biosolids to pre-application soils for TKN and TP were 46 and 24, respectively. The dry mass ratio is determined by both the soil sampling method and the application rate of the biosolids. Soil masses were those in the upper 6 inches and were largely solid phase (median $=80.6$ weight percent solids, range $=77.9-89.5$ weight percent solids). In contrast, biosolids were largely liquid (median $=1.8$ weight percent solids, range $=0.5-4.6$ weight percent solids) and were applied in a thin coating on the fields. Using a bulk density of 1.5 grams per cubic centimeter $\left(\mathrm{g} / \mathrm{cm}^{3}\right)$ for these soil types (Natural Resources Conservation Service, n.d.), these two factors combined to result in a median mass ratio in soil to biosolids samples of $\sim 2,300$ (range $\sim 500$ to $\sim 6,400$ ). So despite the larger elemental concentration in biosolids compared to soil, the mass of biosolids "mixed" into the upper 6 inches of soil in the homogenized core material would be too small to be detected consistently between pre- and post-application soil samples. To further illustrate this, the soil depth was calculated that would need to be sampled in order to see a doubling (a magnitude for which there is confidence in detecting differences) in the elemental concentrations between pre- and post-application samples. The median soil sample depth to achieve doubling in concentration for the 10 elements with EPA ceiling concentrations for land-applied biosolids was calculated to be 0.4 millimeter $(\mathrm{mm})$ thick (range 0.02 to $3.6 \mathrm{~mm}$ ). This "dilution" related to mixing is also true for
TKN and TP where, despite the concentration in biosolids being one or two orders of magnitude higher compared to that in soils, the pre- and post-application concentrations were similar. The median soil sample depth to achieve doubling in concentration for TKN and TP was $1.6 \mathrm{~mm}$ thick (range 0.3 to $5.1 \mathrm{~mm}$ ). Therefore, given the fact that biosolids have been applied to the fields for more than 25 years (representing at least 50 land applications) and the relatively small amount of dry mass of biosolids applied to the fields during each application (illustrated by the very small soil sample core depth that would be needed to detect a doubling of concentrations between pre- and post-application samples), it is not surprising that there is not a detectable difference between pre- and post-application soil samples.

Selected biosolids and soil samples were collected and analyzed for contaminants of emerging concern (five suites including household-, industrial-, and agricultural-use compounds; sterols; pharmaceuticals; hormones; and antibiotics) from biosolids land-application fields AF 11-2, AF 11-4, and AF 11-6 and the background field BF1. The results of all emerging contaminant solid phase samples are presented in appendix table 2-2, which provides a detailed compilation of the organic analytical results for the biosolids and soil samples. Detections of the five suites of contaminants of emerging concern in pre- and post-application and background soils as well as in biosolids as a percentage of analyses are shown in figure 8 . Note that the data depicted represent four pre-application soil samples, four post-application soil samples, five biosolids samples, and one background soil sample. The highest frequency of detections in all media was for the suite of household-, industrial-, and agricultural-use compounds, and these compounds accounted for most of the detections in each media. Hormones were detected in all media though were relatively more abundant in the pre- and post-application soils 


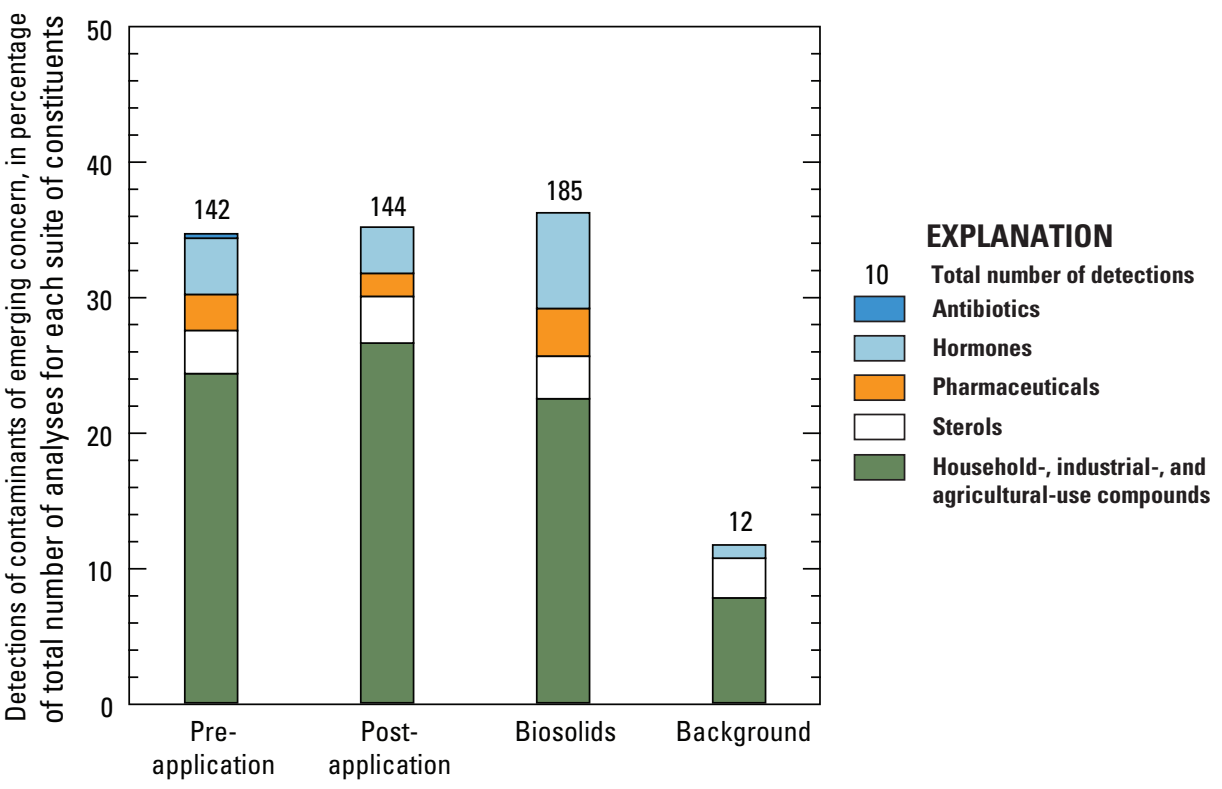

Figure 8. Percentage of detections within the various analytical suites of contaminants of emerging concern in biosolids and soils in the Cane Creek and Collins Creek watersheds in Orange County, North Carolina.

and biosolids compared to the background soil. Pharmaceuticals were largely only detected in the application fields and biosolids. Similar detection frequencies of sterols in application and background soils and biosolids were consistent with natural sources. Finally, only the pre-application soil had detections of the few antibiotics that were included in the pharmaceutical suite.

In a study by Kinney and others (2006), 17 of the 25 contaminants of emerging concern (household-, industrial-, and agricultural-use compounds plus some pharmaceuticals) found in all 9 biosolids samples from seven States were also found in at least 4 of the 5 biosolids samples from this study. These findings extend the conclusions from Kinney that biosolids are more alike than different despite variability in populations contributing wastes to sewage treatment plants and different production methods. Absent of the laboratory analytical performance issues encountered during this study, which could have limited the detections of certain contaminants of emerging concern (see appendix 3 ), it is likely that more of the 25 compounds detected in biosolids samples from the Colorado study would have been detected more frequently in this study.

The number of detections of individual compounds within the five suites of emerging concern, sorted by number of detections in the biosolids samples, is given in table 13 for the application and background fields. As mentioned previously, some of these compounds have poor or unknown performance issues (see appendix 3). Twelve compounds were detected in the background sample. Eleven of the twelve compounds (carbazole, fluoranthene, $p$-cresol, phenanthrene, pyrene, 3-methyl-1(H)indole [skatol], indole, beta-sitosterol, beta-stigmastanol, cholesterol, and 4-androstene-3,17-dione) were also frequently detected in the biosolids-application fields. Of these $11 \mathrm{com}-$ pounds, only 4-androstene-3,17-dione is indicative of wastewater. Therefore, although most of these compounds were frequently detected in biosolids, human wastes are not the only source. More than half of these compounds were also found in agricultural soil in eastern Colorado prior to any biosolids application (Yager and others, 2014). The twelfth compound detected in the background field was anthracene, which was not detected in any biosolids-application field. Anthracene was, however, detected in most (four out of five) of the biosolids samples. The nonpersistence of anthracene in soils is consistent with loss due to volatilization, solubilization, and subsequent movement away from the application area, and (or) bacterial degradation. Higher rates of polycyclic aromatic hydrocarbon $(\mathrm{PAH})$ degradation have been noted in soils amended with biosolids compared to soils that have not, likely due to the associated nutrient addition stimulating bacterial metabolism of these compounds as energy or carbon sources (Haritash and Kaushik, 2009).

There was a general increase in the number of detections of contaminants of emerging concern in the application fields as the number of detections in the five biosolids samples increased though it was not pronounced (table 13). Compounds that are often detected in both the biosolids-application soils and the biosolids samples but not in the background field include 2,6-dimethylnaphthalene, benzo[a]pyrene, 3-beta-Coprostanol, 
Table 13. Number of detected individual contaminants of emerging concern in biosolids and soil samples collected from agricultural fields in the Cane Creek and Collins Creek watersheds in Orange County, North Carolina.

[Dark red shading, two detections; light red shading, one detection; no shading, no detection]

\begin{tabular}{|c|c|c|c|c|c|c|}
\hline \multirow{2}{*}{ Contaminants of emerging concern } & Biosolids & $\begin{array}{c}\text { Field } \\
\text { AF 11-2 }\end{array}$ & $\begin{array}{c}\text { Field } \\
\text { AF 11-4 }\end{array}$ & $\begin{array}{l}\text { Field } \\
11-4\end{array}$ & $\begin{array}{c}\text { Field } \\
\text { AF 11-6 }\end{array}$ & $\begin{array}{l}\text { Background } \\
\text { field }\end{array}$ \\
\hline & (5 samples) & (2 samples) & (2 samples) & (2 samples) & (2 samples) & (1 sample) \\
\hline
\end{tabular}

\begin{tabular}{|c|c|c|c|c|c|c|}
\hline \multicolumn{7}{|c|}{ Household, industrial, and agricultural-use compounds } \\
\hline Anthraquinone & 0 & 2 & 2 & 2 & 2 & ( \\
\hline Atrazine & 0 & 0 & 0 & 0 & 2 & ( \\
\hline Triphenyl phosphate & 0 & 1 & 1 & 2 & 1 & ( \\
\hline 1,4-Dichlorobenzene & 1 & 2 & 2 & 2 & 2 & ( \\
\hline 4-Nonylphenol diethoxylate $(\mathrm{NP} 2 \mathrm{EO})^{1}$ & 1 & 0 & 0 & 0 & 0 & ( \\
\hline 4-tert-Octylphenol diethoxylate (OP2EO) & 1 & 0 & 0 & 0 & 0 & ( \\
\hline 4-tert-Octylphenol monoethoxylate (OP1EO) & 1 & 0 & 0 & 0 & 0 & ( \\
\hline Acetophenone & 1 & 0 & 1 & 2 & 1 & c \\
\hline Carbazole & 1 & 2 & 2 & 2 & 2 & 1 \\
\hline Tris(dichloroisopropyl)phosphate & 1 & 0 & 0 & 0 & 0 & ( \\
\hline 2-Methylnaphthalene & 2 & 2 & 2 & 2 & 1 & ( \\
\hline 2,6-Dimethylnaphthalene & 3 & 2 & 2 & 2 & 2 & c \\
\hline Bisphenol A & 3 & 2 & 2 & 2 & 0 & c \\
\hline Camphor & 3 & 0 & 0 & 0 & 0 & ( \\
\hline Menthol & 3 & 1 & 0 & 0 & 0 & c \\
\hline Anthracene & 4 & 0 & 0 & 0 & 0 & 1 \\
\hline Benzo $[a]$ pyrene & 4 & 2 & 2 & 2 & 2 & c \\
\hline bis(2-Ethylhexyl) phthalate & 4 & 2 & 2 & 2 & 0 & ( \\
\hline 3-Methyl-1(H)-indole (Skatole) & 5 & 2 & 2 & 2 & 2 & 1 \\
\hline 4-Nonylphenol ${ }^{1}$ & 5 & 2 & 2 & 2 & 1 & c \\
\hline 4-Nonylphenol monoethoxylate $(\mathrm{NP} 1 \mathrm{EO})^{1}$ & 5 & 2 & 2 & 2 & 1 & c \\
\hline 4-tert-Octylphenol & 5 & 2 & 2 & 2 & 1 & c \\
\hline Acetyl hexamethyl tetrahydronaphthalene (AHTN) & 5 & 2 & 2 & 2 & 2 & ( \\
\hline 2,2',4,4'-Tetrabromodiphenylether (PBDE 47) & 5 & 2 & 2 & 2 & 2 & ( \\
\hline Benzophenone & 5 & 2 & 2 & 2 & 1 & c \\
\hline d-Limonene & 5 & 2 & 2 & 2 & 2 & c \\
\hline Hexahydrohexamethylcyclopentabenzopyran (HHCB) & 5 & 1 & 2 & 2 & 1 & c \\
\hline Indole & 5 & 2 & 2 & 2 & 2 & 1 \\
\hline Triclosan & 5 & 2 & 2 & 2 & 2 & ( \\
\hline
\end{tabular}


Table 13. Number of detected individual contaminants of emerging concern in biosolids and soil samples collected from agricultural fields in the Cane Creek and Collins Creek watersheds in Orange County, North Carolina.-Continued

[Dark red shading, two detections; light red shading, one detection; no shading, no detection]

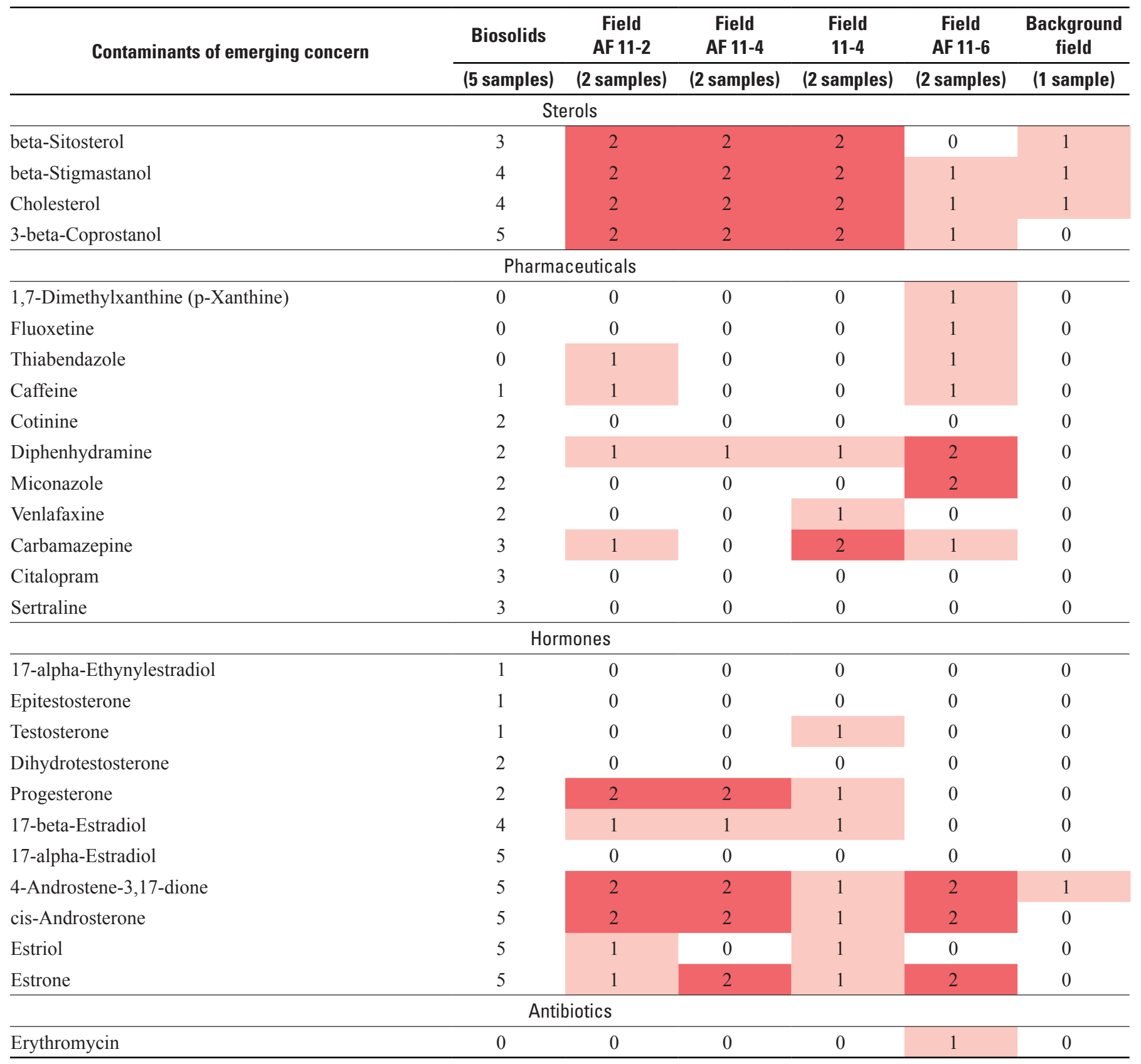

\footnotetext{
${ }^{1}$ Sum of all isomers.
} 
acetylhexamethyl tetrahydronaphthalene (AHTN), 2,2',4,4'-tetrabromodiphenylether (PBDE 47), d-limonene, and triclosan. For these compounds, biosolids are likely the predominate source to the biosolids-application soils. Compounds that are often detected in the biosolids-application soils but rarely or never in biosolids include anthraquinone, triphenyl phosphate, and 1,4-dichlorobenzene. Most detections of these compounds in soil samples were estimated (E-coded) and almost all biosolids samples had LRLs well above the estimated value. Therefore, biosolids may not be the source of these compounds in the soil, or matrix interferences may have prevented detection of the compounds in the biosolids samples. Compounds found frequently in biosolids but infrequently or never in biosolids-application soils include camphor, anthracene, and DEET ( $N, N$-diethyl-meta-toluamide) among the household-, industrial-, and agricultural-use compounds, citalopram and sertraline among the pharmaceuticals, and 17-alpha-estradiol among the hormones. The reason for these compounds being frequently detected in biosolids but infrequently or never detected in the biosolids-application soils might be due to post-application degradation or the dilution effect of the relative small mass of land-applied biosolids to that of the soils as previously discussed. A summary of the concentrations of all detections in soils and biosolids samples is presented in table 14.

Various hydrocarbons were detected in a few biosolids and soil samples (table 15). These compounds included BTEX (benzene, toluene, ethylbenzene, and xylenes), gasoline-range organics (C6-C10), motor oil range organics (C24-C36), total extractable hydrocarbons (C10-C36), HEM (n-hexane extractable materials), SGT-HEM (silica gel treated $n$-hexane extractable material), and the fuel oxygenate MTBE (methyltert-butyl ether). Although most of these compounds were detected in the biosolids samples, only HEM, motor oil range organics, and total extractable hydrocarbons were often detected in soils and in similar concentrations between the two media. If biosolids were the main source of BTEX and gasoline range organics, these compounds appeared to be lost rapidly (days), likely due to volatilization. 


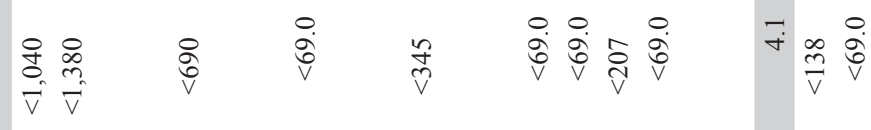

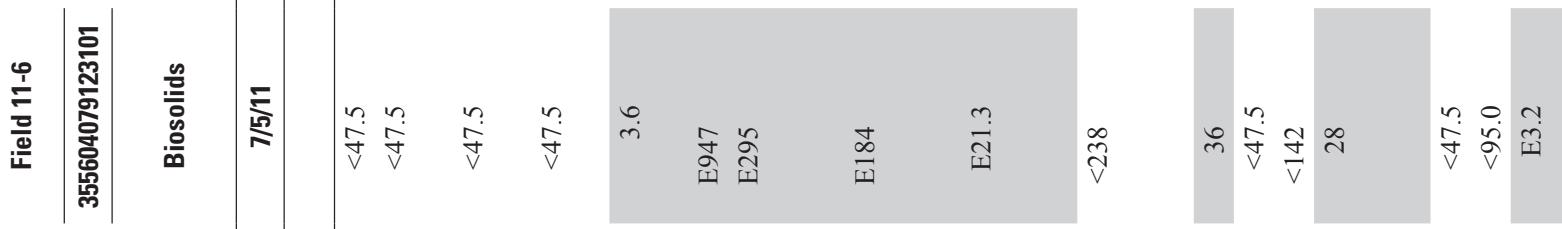

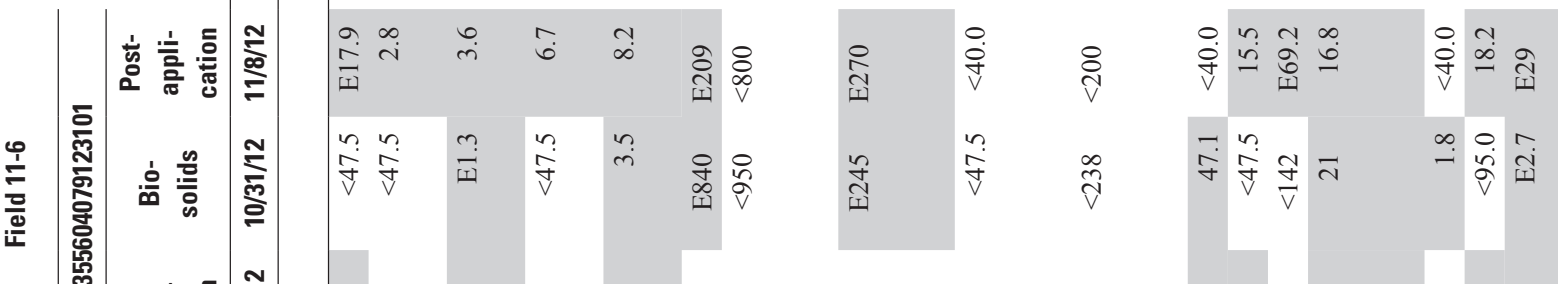

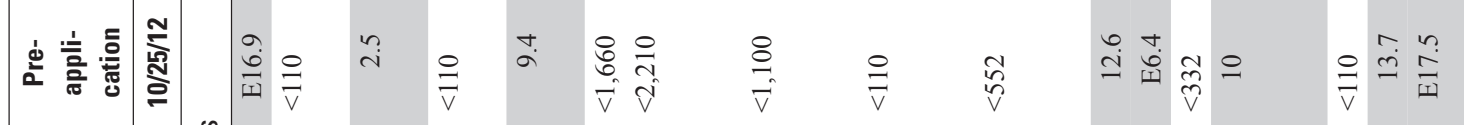

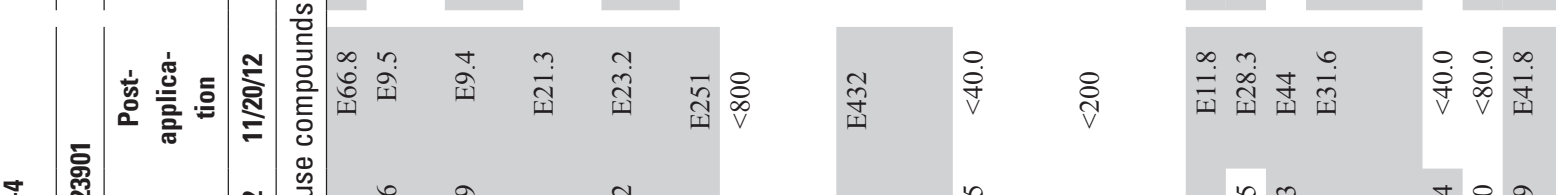

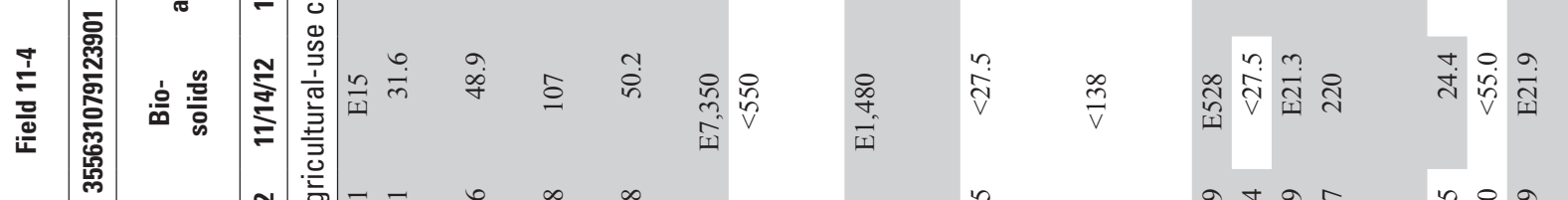

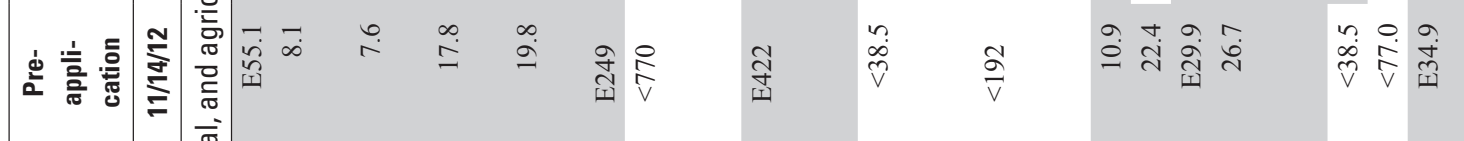

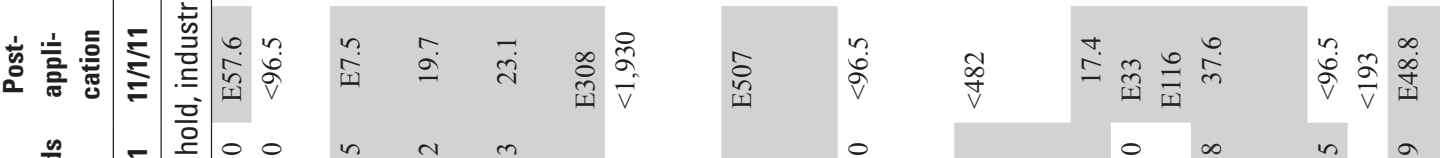

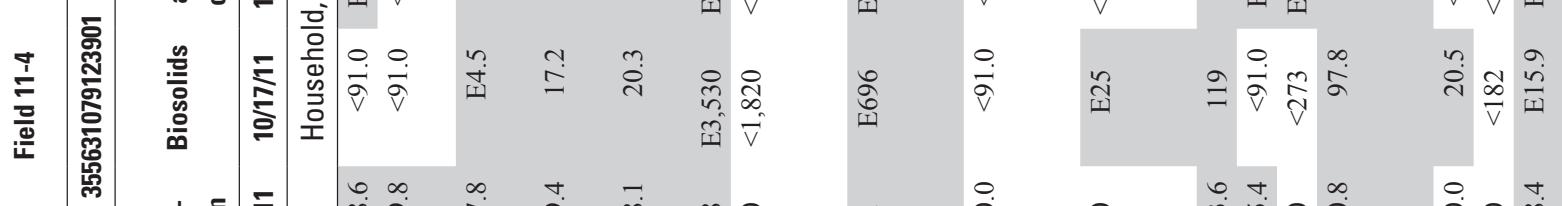

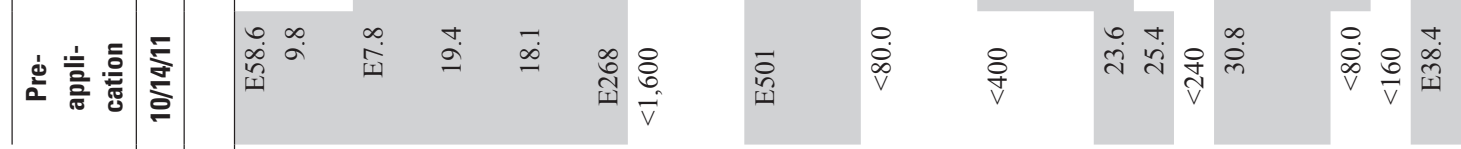

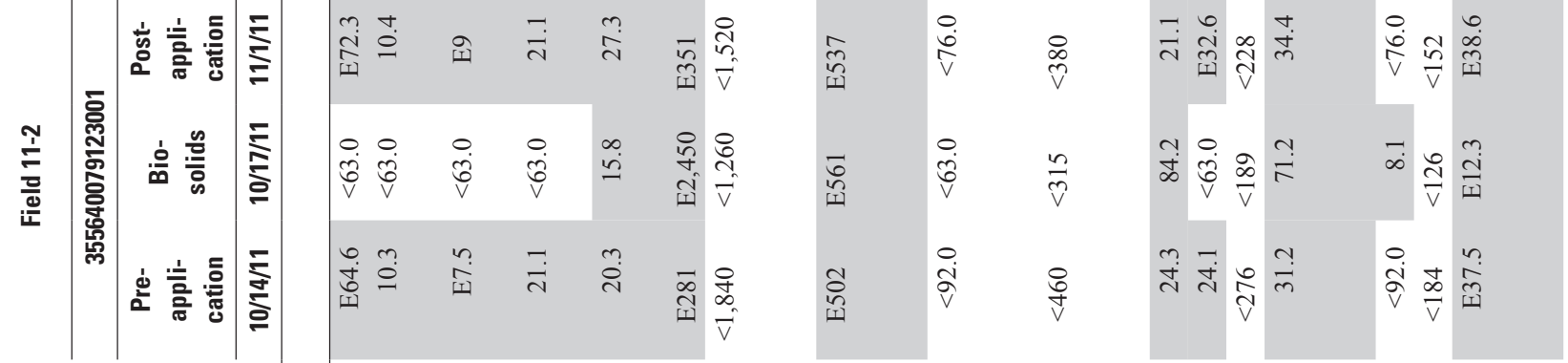

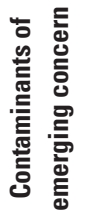

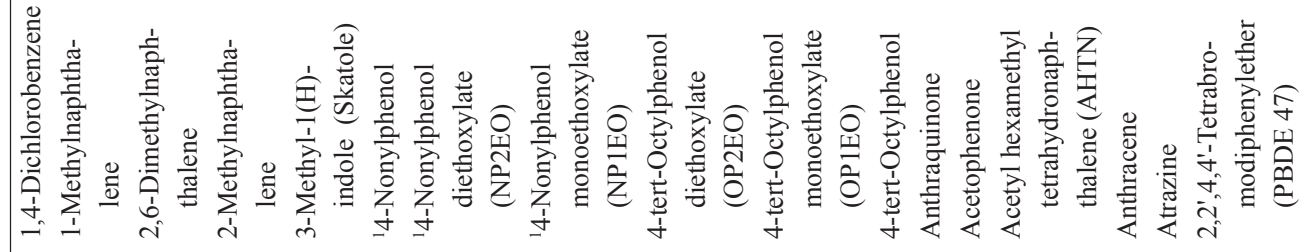




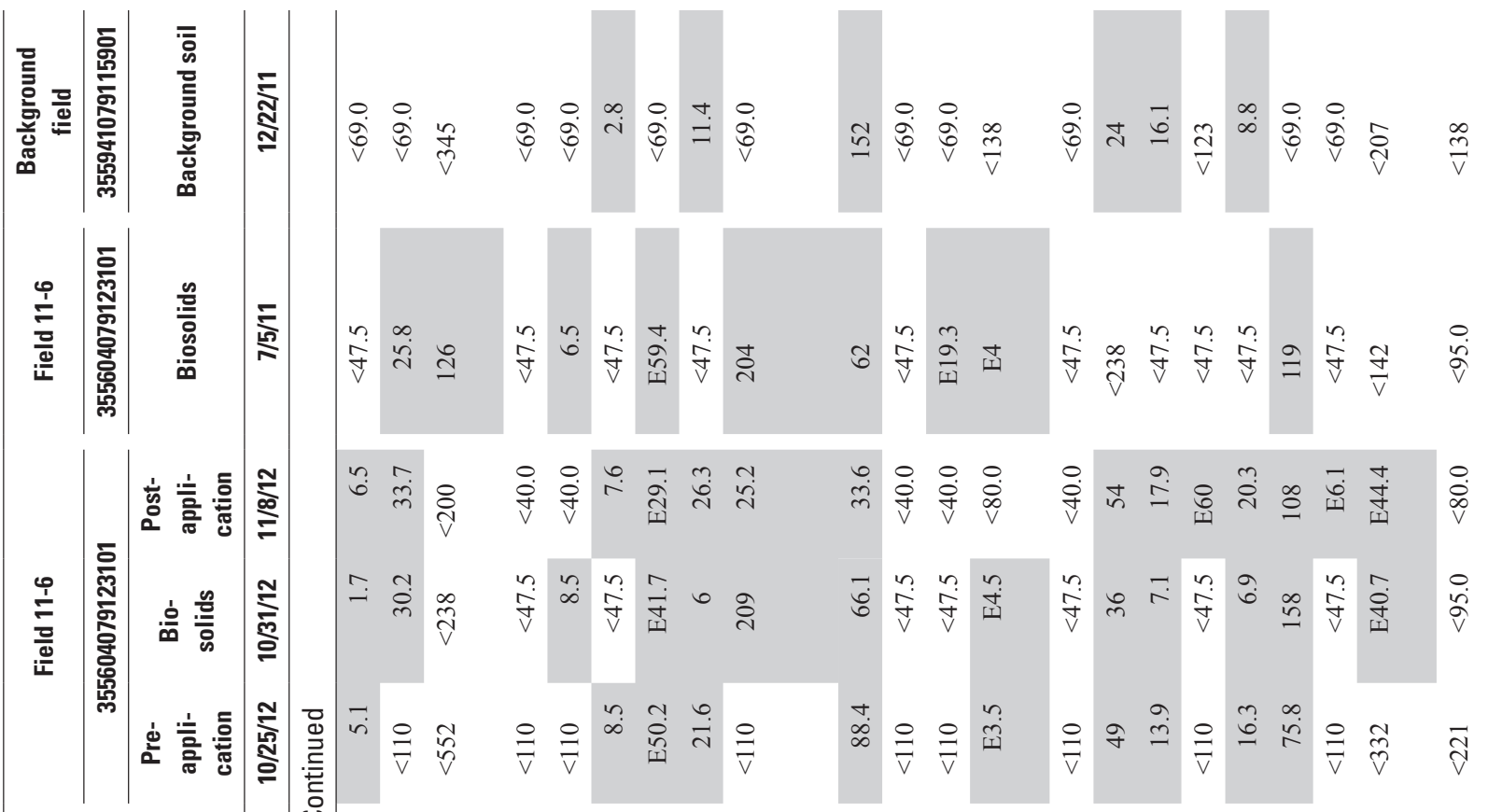

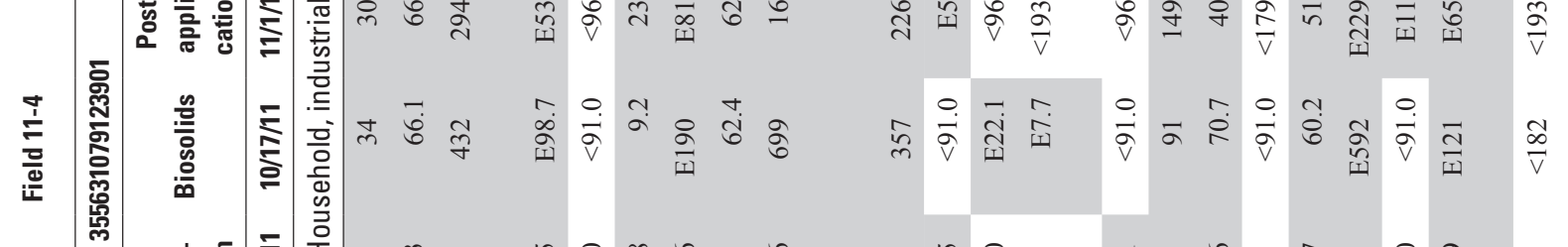

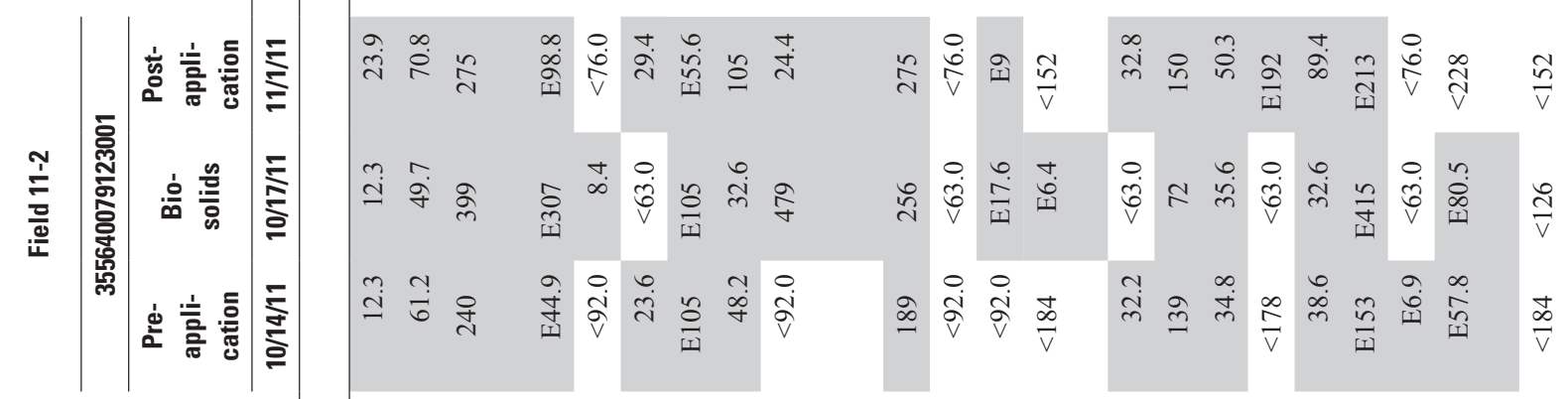

d 


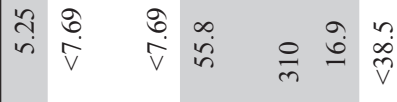
m

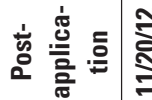

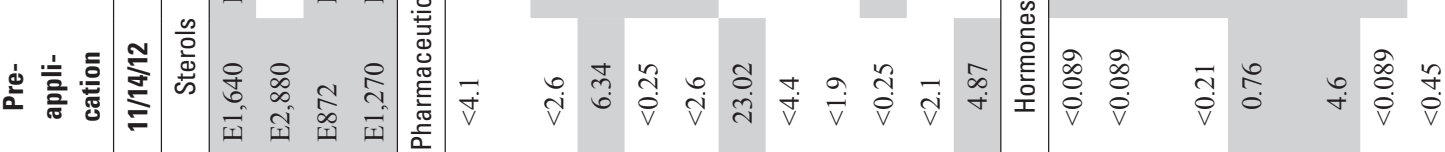

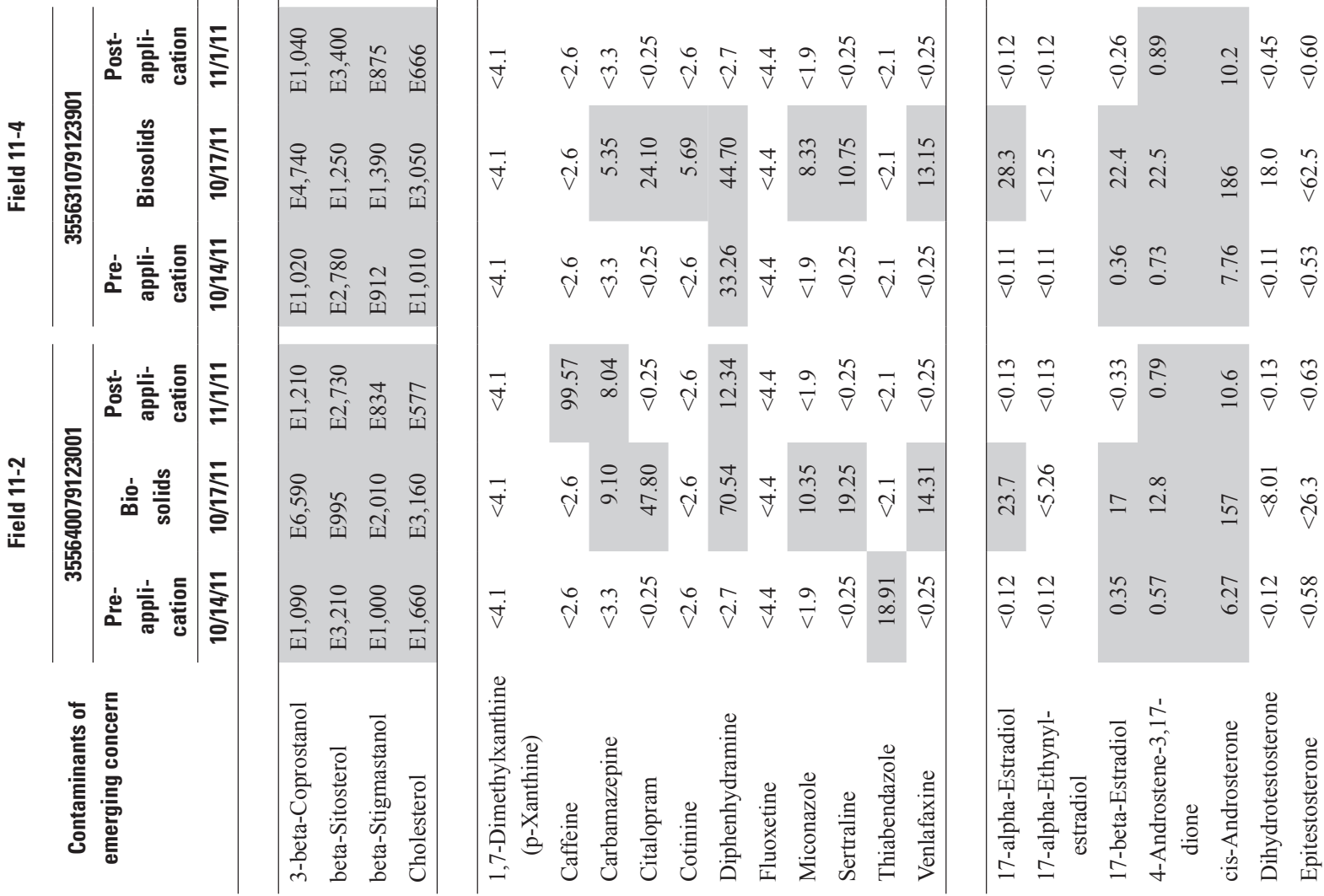




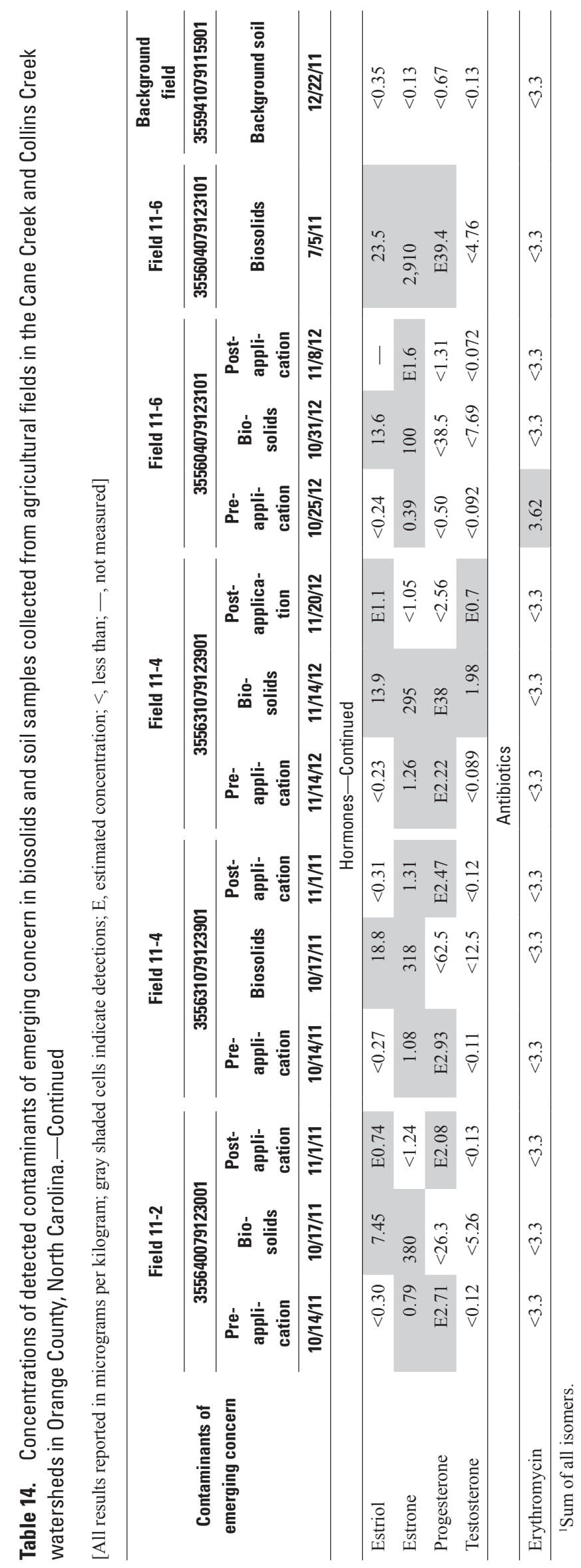




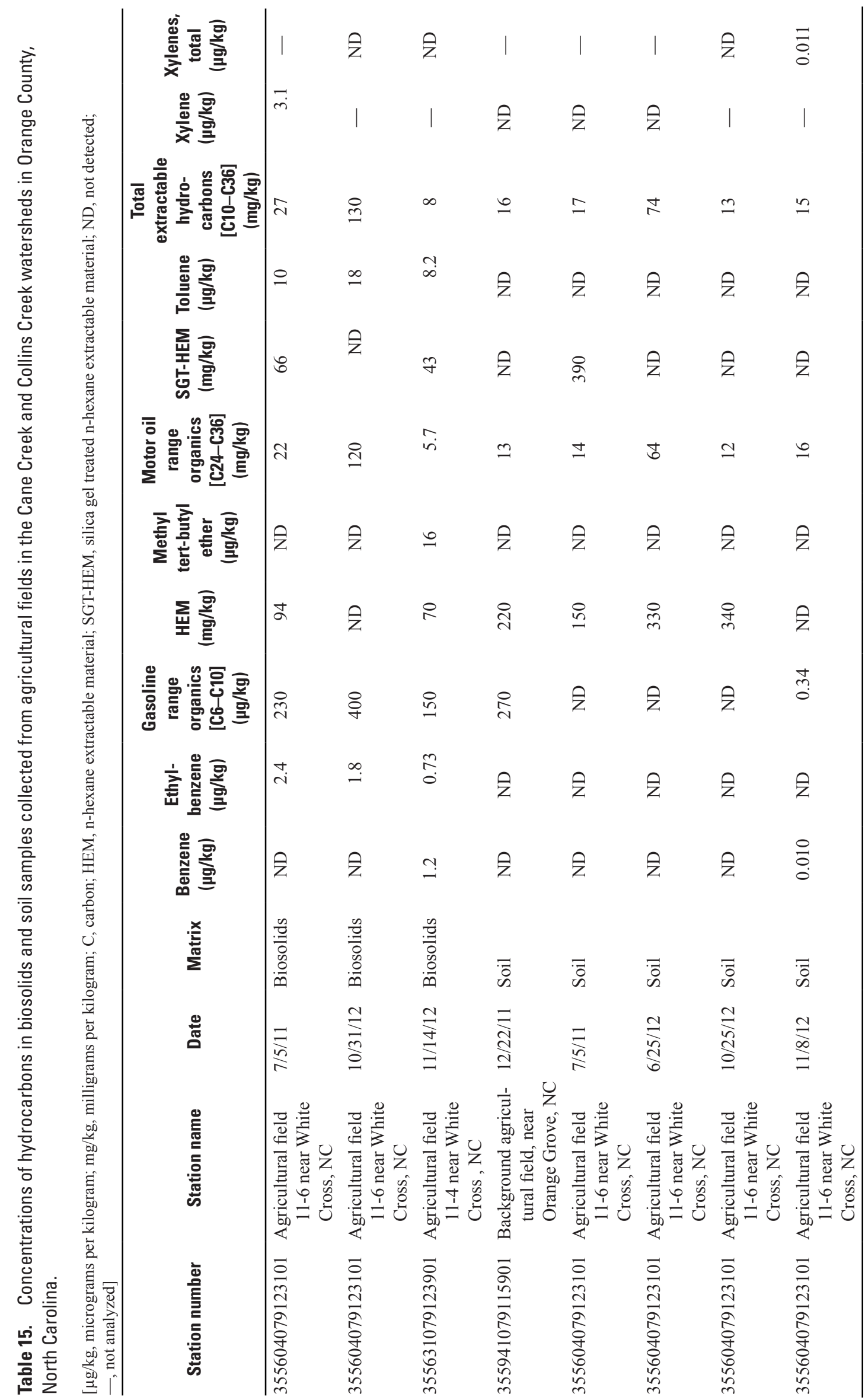




\section{Genetic Biomarkers}

Given that there were cattle grazing on the biosolids land-application fields, an evaluation was conducted to try to determine if there were specific host-associated genetic biomarkers that could distinguish the source of fecal indicator bacteria in soil and surface-water samples as being primarily from municipal human waste biosolids or cattle manure. The biosolids and cattle manure source materials were first tested to determine whether they contained the host-associated biomarkers of interest and to assure that there was no cross-reactivity of host-associated biomarkers and fecal sources. Quantitative exogenous extraction and amplification controls indicated negligible PCR inhibition and an average recovery of 24.6 percent of genomic DNA from manure/biosolids samples and 20.2 percent from soil samples. As expected, there was no detection of cattle-associated biomarkers (CowM1, CowM2, or CF128) in the Class A biosolids samples or human-associated biomarkers (HF183 or HumM2) in the cattle manure samples.

Interestingly, the CowM1 and CowM2 host-associated genetic markers were not detected at concentrations that exceeded the analytical limits of detection in cattle manure samples. Although the reasons remain unknown, it has previously been reported that these host-associated genetic biomarkers decay rapidly to undetectable levels in environmental samples, which may explain their absence (Rogers and others, 2011). However, there was strong detection of CF128 in the cattle manure samples, so this marker was used for microbial source tracking in the surface-water samples.

The biosolids of this study that were analyzed for biomarkers were treated to meet Class A pathogen reduction requirements - stringent standards that assure a high degree of bacterial kill prior to land application (typically four orders of magnitude or greater). Biosolids were sampled following Class A treatment. Concentrations of total Bacteroidales 16S rDNA in the biosolids, as measured by the GenBac3 qPCR genetic biomarker, ranged from $10^{3}$ to $10^{4}$ copies per gram, several orders of magnitude lower than typical untreated sewage sludge. Therefore, it is not surprising that the concentrations of human-associated genetic biomarkers, HumM2 and HF183, were below the analytical limits of detection in all biosolids samples that were analyzed. Positive control samples from the Potsdam, N.Y., sewage treatment plant exhibited strong and positive amplification of these gene targets in all reaction plates, indicating that the amplification reactions proceeded as expected. Considering the results above, all water samples were screened against the CF128 genetic biomarker as an indicator of cattle fecal pollution.

\section{Groundwater}

The following sections summarize measured groundwater levels and quality at the six monitoring wells drilled as part of this study, four of which were installed adjacent to the agriculture fields with land-applied biosolids (OR-685, OR-686, OR-687, and OR-688) and two of which were installed adjacent to an agriculture field with no history of land-applied biosolids or animal manure (OR-689 and OR-690) (table 1). The installation of all six monitoring wells for the study was completed by NCDENR in May 2011, and water-quality sampling was conducted quarterly by the USGS and NCDENR from June 2011 to March 2013. The information presented provides the framework for characterizing and comparing constituent concentrations in shallow groundwater underlying agricultural watersheds with and without land-applied biosolids.

\section{Water Levels}

The quarterly groundwater-quality sampling at the six monitoring wells detected a range of water-level conditions with drought conditions in the summer and fall of 2011 and high water-table conditions in March of 2012 and 2013 (fig. 9). Continuous water-level monitors were installed and operated by Orange County in wells OR-685, OR-687, and OR-688 for most of the study period. These data are presented in figure 9 along with the USGS water-level measurements made during water-quality sampling events.

Climatic and seasonal trends in groundwater levels were similar to fluctuations observed in the surficial aquifer across the piedmont in the southeastern United States (U.S. Geological Survey, 2012). Elevated groundwater levels generally occurred during the late winter or early spring following fall and winter precipitation. As a result of increased evapotranspiration (ET) and reduced precipitation during the summer months, groundwater levels declined in the summer. Groundwater levels recorded continuously in wells OR-685, OR-687, and OR-688 generally responded quickly to infiltration from precipitation events. Rainfall events with a long duration and moderate intensity had the greatest effect on recharge to the groundwater system, especially during the late fall and winter months when ET rates were low and soil moisture was high, allowing more rainfall to infiltrate to the water table. This occurrence was most notable during November 2011 when groundwater levels were low because of persistent drought conditions.

Wells OR-686 and OR-687 were installed along the upgradient edge and downgradient edge, respectively, of application field AF 11-6 along an assumed flow path within a conceptual "slope-aquifer" system (LeGrand and Nelson, 2004). The "slope-aquifer" system assumes that groundwater recharge occurs at hilltops and groundwater discharge occurs in stream valleys. On application field AF 11-6, well OR-686 was installed at the topographic high and well OR-687 was installed topographically mid-slope to Collins Creek, which is the surface-water drain for the surficial aquifer (fig. 2). Well OR-688 was installed in a discharge area for the surficial aquifer, as the well is located in the floodplain of Collins Creek at the base of field AF 11-7 (fig. 2). A comparison of the water levels measured in well OR-686, well OR-687, and Collins Creek (fig. 9) shows that a downward hydraulic gradient was measured throughout the study period across application field $\mathrm{AF}$ 11-6. Also, the groundwater level in well OR-688 on the edge of the Collins Creek floodplain was generally about $0.6 \mathrm{ft}$ higher 


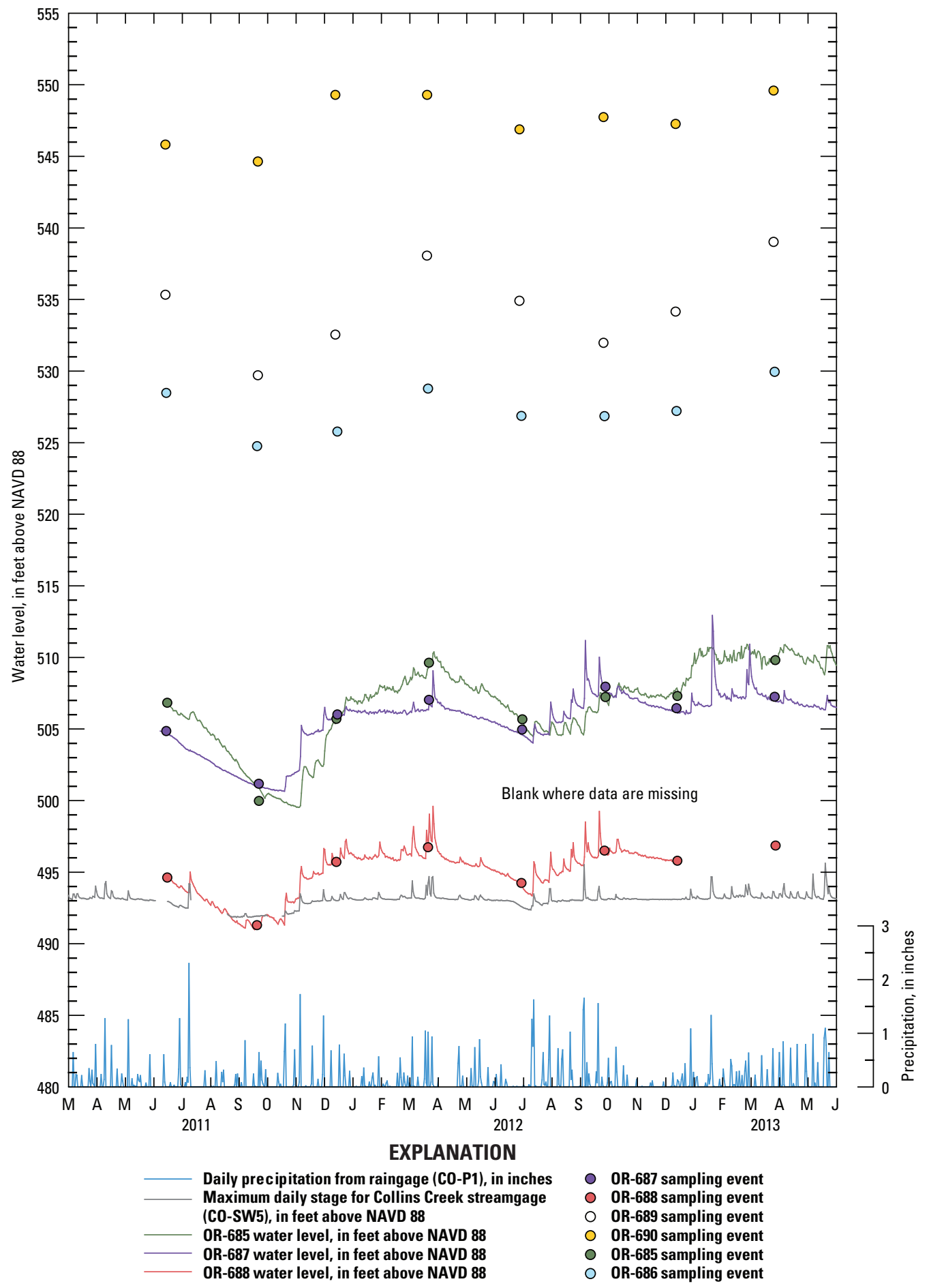

Figure 9. Daily precipitation for U.S. Geological Survey rain gage (355637079122545, site ID C0-PI) maximum daily stage for a streamgage on Collins Creek (0209691611, site ID C0-SW5), and water-level and groundwater sampling events for wells OR-685, 0R-686, 0R-687, 0R-688, OR-689, and OR-690, in Orange County, North Carolina. 
than the water level of the creek, except during times of drought (such as August to October 2011), when the hydraulic gradients reversed and Collins Creek was no longer gaining discharging groundwater (fig. 9). A water-table map was constructed for the application field AF11-6 using groundwater level measurements made on March 26 and 27, 2013 (fig. 10). The average hydraulic gradient across field AF 11-6 was 0.018 foot per foot (ft/ft), which is about half of the topographic gradient.

\section{Water Quality}

A compilation of the analytical results for the groundwater samples collected at all sites is presented in appendix table 2-3. The water type in terms of cations and anions within the six monitoring wells is diverse (fig. 11). Wells OR-687, OR-688, and OR-690 have similar water type, as do wells OR-685 and OR-689, although well OR-686 is distinct from both of those groups (fig. 11) and potentially represents conditions with the least amount of agricultural influence as it is upgradient from agricultural fields (fig. 2). Although the water types among the six monitoring wells are diverse, the fact that the groupings of wells with similar water types include wells that are adjacent to fields with and without land-applied biosolids illustrates that there are similarities between the soils and geology among the wells despite the differences in fertilizer practices within the overlying agriculture fields. Groundwater from wells OR-685 and OR-689 were both calcium-bicarbonate type, and water from wells OR-687 and OR-688 were calcium-nitrate/chloride type waters. Well OR-690 had calcium/sodium-bicarbonate/ nitrate/chloride type water, and well OR-686, which may most closely represent pre-agricultural conditions, had calcium/ sodium-bicarbonate type water.

Water-quality laboratory results are used herein to characterize groundwater conditions underlying agricultural fields with and without land-applied biosolids. Comparisons of groundwater inorganic and organic constituent concentrations collected quarterly over 2 years are used in the characterization. The comparisons focus mainly on the primary nutrients (nitrogen, phosphorus, and potassium), selected secondary nutrients (calcium), and chloride and sodium, which are found in animal manure and commercial fertilizers commonly used in North Carolina for growing crops (Zublena and others, 1991; Tucker, 1999). These characterizations and comparisons provide insight into (1) the differences in the amount of monitored constituents that are present in shallow groundwater under agricultural fields with and without land-applied biosolids, and (2) the potential effect of land-applied biosolids on shallow groundwater quality and its contribution to surface-water quality. 


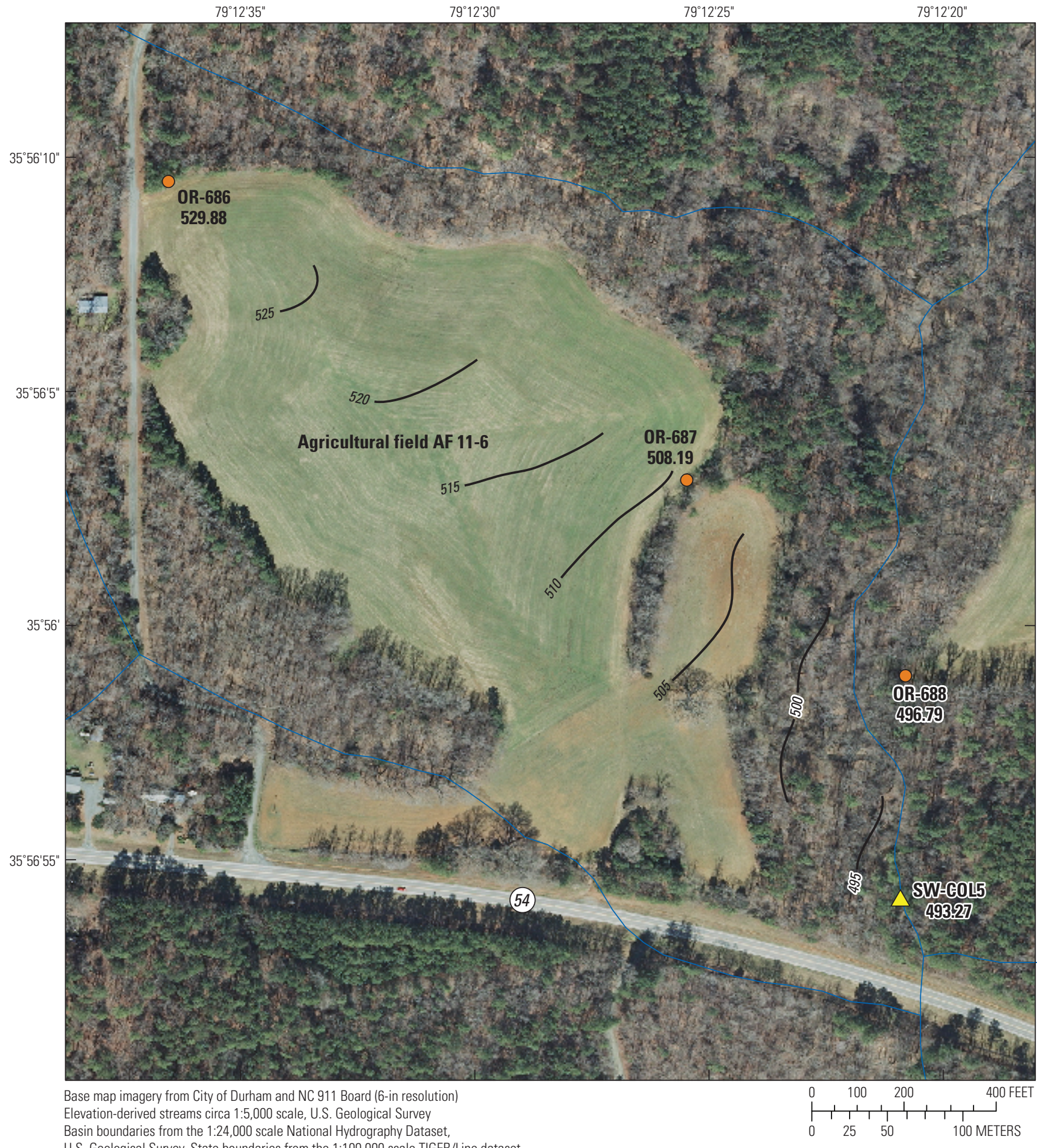

U.S. Geological Survey, State boundaries from the 1:100,000 scale TIGER/Line dataset,

U.S. Census Bureau Projection: North Carolina State Plane (feet), NAD 1983

\section{EXPLANATION}

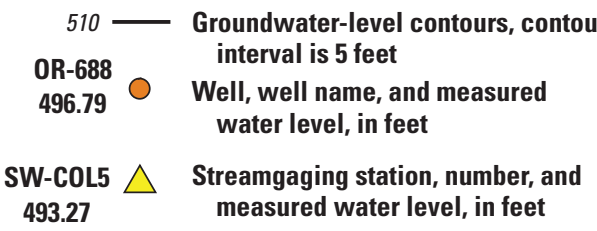

Figure 10. Water-level surface in the surficial aquifer in the Collins Creek watershed, Orange County, North Carolina, March 2013. 


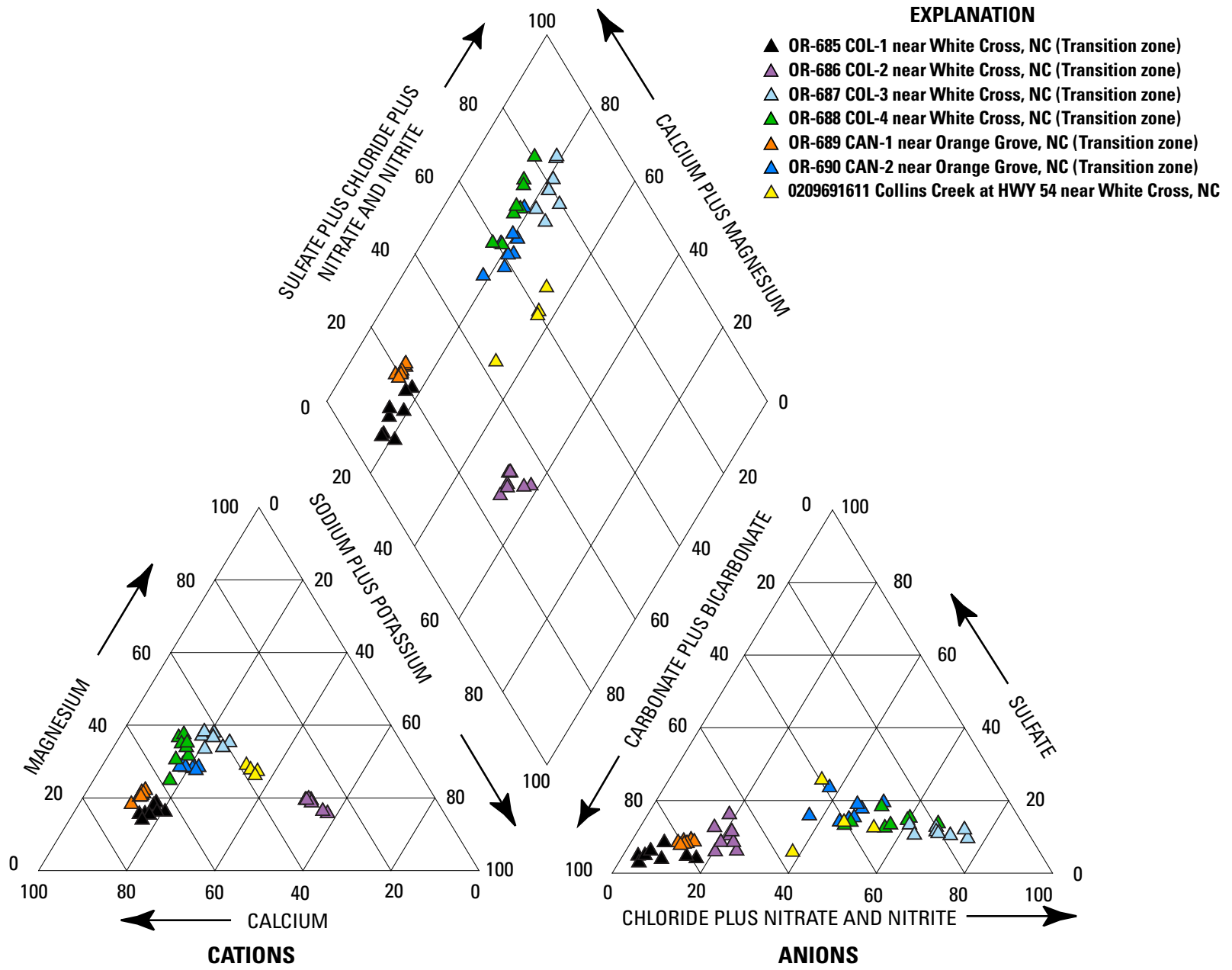

Figure 11. Water chemistry data from June 2011 to March 2013 displayed on a tri-linear Piper diagram from sampled wells and baseflow samples collected from U.S. Geological Survey streamgage and water-qualtiy monitoring site (0209691611, CO-SW5) on Collins Creek in Orange County, North Carolina. 


\section{Summary and Statistical Analysis of Groundwater Constituent Concentrations}

Statistical comparison testing was conducted to determine if there were statistically significant differences in groundwater concentrations of nutrients and selected ions between winter/spring and summer/fall seasons and (or) among the six groundwater monitoring wells. Statistical analyses for the bacteria and metals with EPA ceiling concentrations for land-applied biosolids (see appendix table 2-3) were not performed because these compounds either were detected in very few samples (for bacteria samples, about 80 percent of the results were censored values) or all of the concentrations were estimated to be less than the long-term method detection level (LT-MDL).

There was no statistical difference between the winter/ spring and summer/fall seasonal groupings for nitrate $(\mathrm{p}=0.293), \mathrm{TN}(\mathrm{p}=0.464), \mathrm{TP}(\mathrm{p}=0.869)$, chloride $(\mathrm{p}=0.829)$, calcium $(0.862)$, potassium $(\mathrm{p}=0.951)$, or sodium $(\mathrm{p}=0.516)$ at the six monitoring wells. There was an inadequate number of detections to conduct statistical testing on the bacteria data.

A summary of the range in measured nutrient, bacteria, and selected ion concentrations in the six groundwater monitoring wells is presented in figure 12, and the multiple comparison statistical testing results among the wells is presented in table 16. The nitrate concentrations in well OR-686, which is located adjacent to biosolids application fields but upgradient from areas of application and downgradient from a large tract of forest that is not owned by OWASA, are lower and statistically different than concentrations in all of the other study wells (table 16; fig. 12A). Additionally, the upgradient well OR-686 and background wells OR-689 and 690, which are not directly influenced by biosolids application, have much less variability in nitrate concentrations than the other wells. Wells OR-687 and OR-688 are located adjacent to and topographically downgradient from all the biosolids application fields and were found to be statistically different and have higher nitrate concentrations than all the other wells (table 16; fig. 12A). Median nitrate concentrations of samples collected from wells OR-687 and OR-688 (12.4 mg/L and $10.7 \mathrm{mg} / \mathrm{L}$, respectively) were above the EPA drinking-water standard of $10 \mathrm{mg} / \mathrm{L}$. The nitrate concentrations measured in the wells adjacent to the background agricultural field, OR-689 and OR-690, are statistically different from each other and wells OR-686, OR-687, and OR-688 but are not different from well OR-685 (table 16; fig. 12A). Comparisons among the wells for TN concentrations mimic the results for nitrate because nitrate was the dominant species of nitrogen in the wells (table 16; fig. 12C). Overall, TP concentrations in the wells were relatively low, but there were statistical differences among the wells adjacent to the biosolids fields (except between wells OR-687 and 686) and between the wells in the background agricultural field and those adjacent to the biosolids application fields (except for well OR-688) (table 16; fig. 12D). The results of the statistical comparison tests for the selected ions did not indicate any trend among the wells, and overall there was significant variability among the selected ion concentrations measured in the wells during the study (table 16; figs. $12 B, 12 G-I$ ), which likely is attributed to the local variability in geochemistry of soils and geology.

To further evaluate any differences in the shallow groundwater quality under agricultural fields with and without land-applied biosolids and the groundwater contribution to surface-water quality, the median concentrations of EPA-listed contaminants with ceiling concentrations for land-applied biosolids and nutrients is presented in table 17. Except for dissolved nickel concentrations in wells OR-685 and OR-688, the median concentrations of all of the constituents with EPA ceiling concentrations were less than the long-term detection limit that was established by the NCDENR water-quality laboratory that conducted the analysis of these constituents (tables 7 and 17).

Shallow groundwater samples were collected in December 2011 and analyzed for contaminants of emerging concern (household-, industrial-, and agricultural-use compounds, sterols, pharmaceuticals, hormones, and antibiotics) from five of the six monitoring wells. The contaminants of emerging concern results of all groundwater samples are presented in appendix table 2-3, which provides a compilation of the analytical results for organic shallow groundwater samples collected from the monitoring wells.

Household-, industrial-, and agricultural-use compounds were the only constituents detected in the groundwater samples (fig. 13). Well OR-686 had the most total detections (14), followed by well OR-685 (7) (fig. 13), and the detections at all wells were at low levels - typically at or just above the reporting levels (tables 5 and 18). Although well OR-686 is topographically upgradient from the biosolids land-application fields, the well is located directly adjacent to two private residences that are on septic systems, which may explain the elevated number of contaminants of emerging concern detections relative to the other wells. These analytical results indicate that the contaminants of emerging concern, in general, do not appear to be good indicators of human waste contaminants derived from land-applied biosolids in groundwater because the number of detections and concentrations at the background well OR-690 are similar to those wells downgradient and adjacent to the biosolids landapplication fields (OR-687 and OR-688) (fig. 13; table 18). 

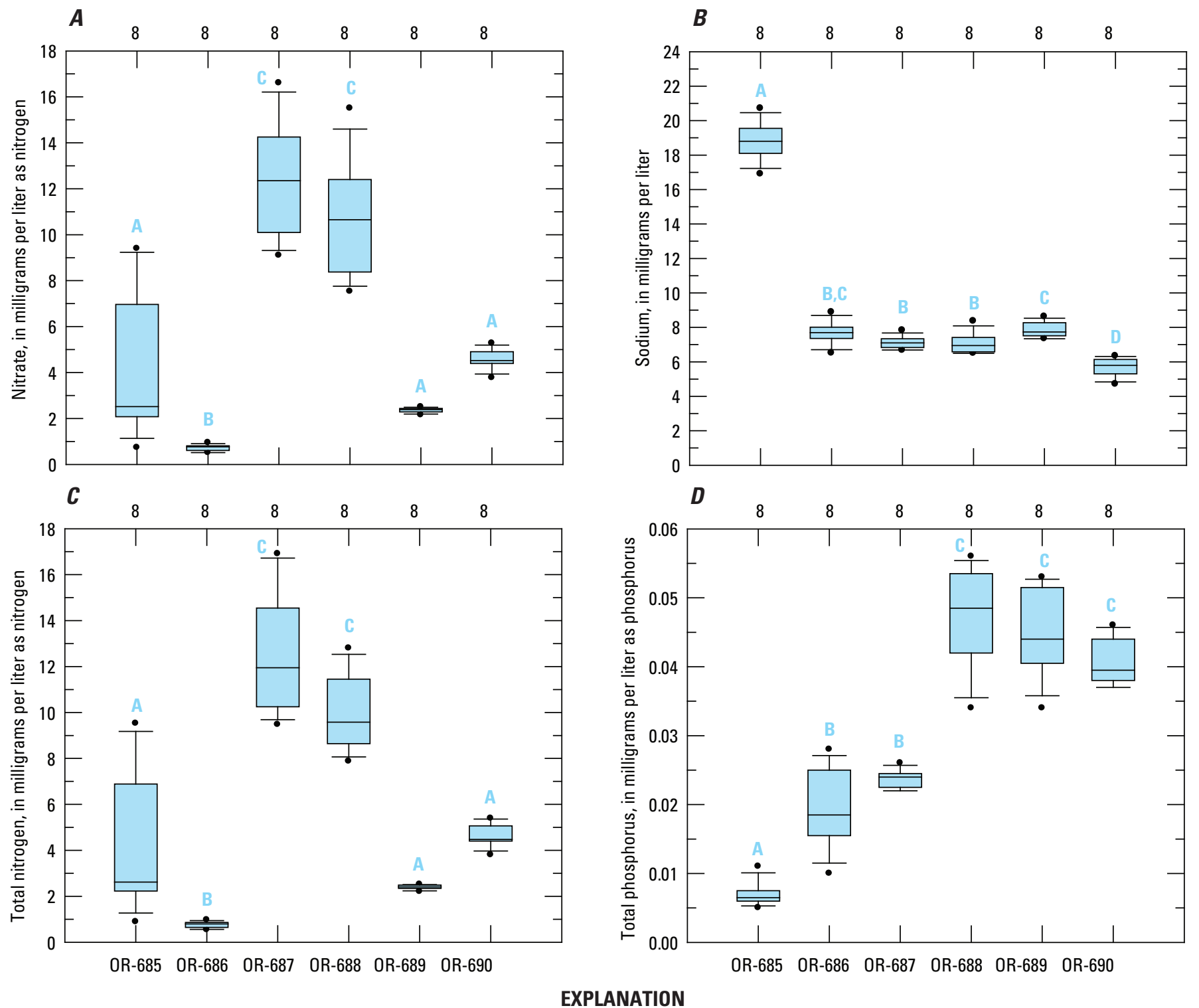

EXPLANATION

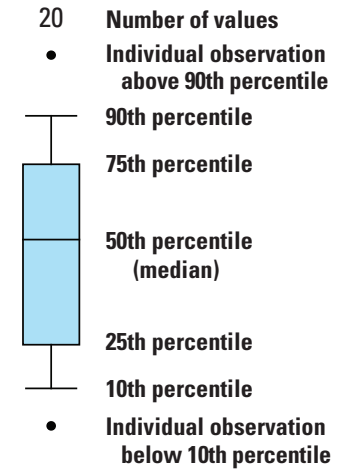

$A, B, C$ Indicates results of multiple comparison statistical testing among groundwater wells

Figure 12. Concentrations of $(A)$ nitrate, $(B)$ sodium, $(C)$ total nitrogen, $(D)$ total phosphorus, $(E)$ Escherichia coli, $(F)$ fecal coliform, $(G)$ chloride, $(H)$ calcium, and (/) potassium in wells 0R-685, 0R-686, 0R-687, 0R-688, 0R-689, and 0R-690 in Orange County, North Carolina. 

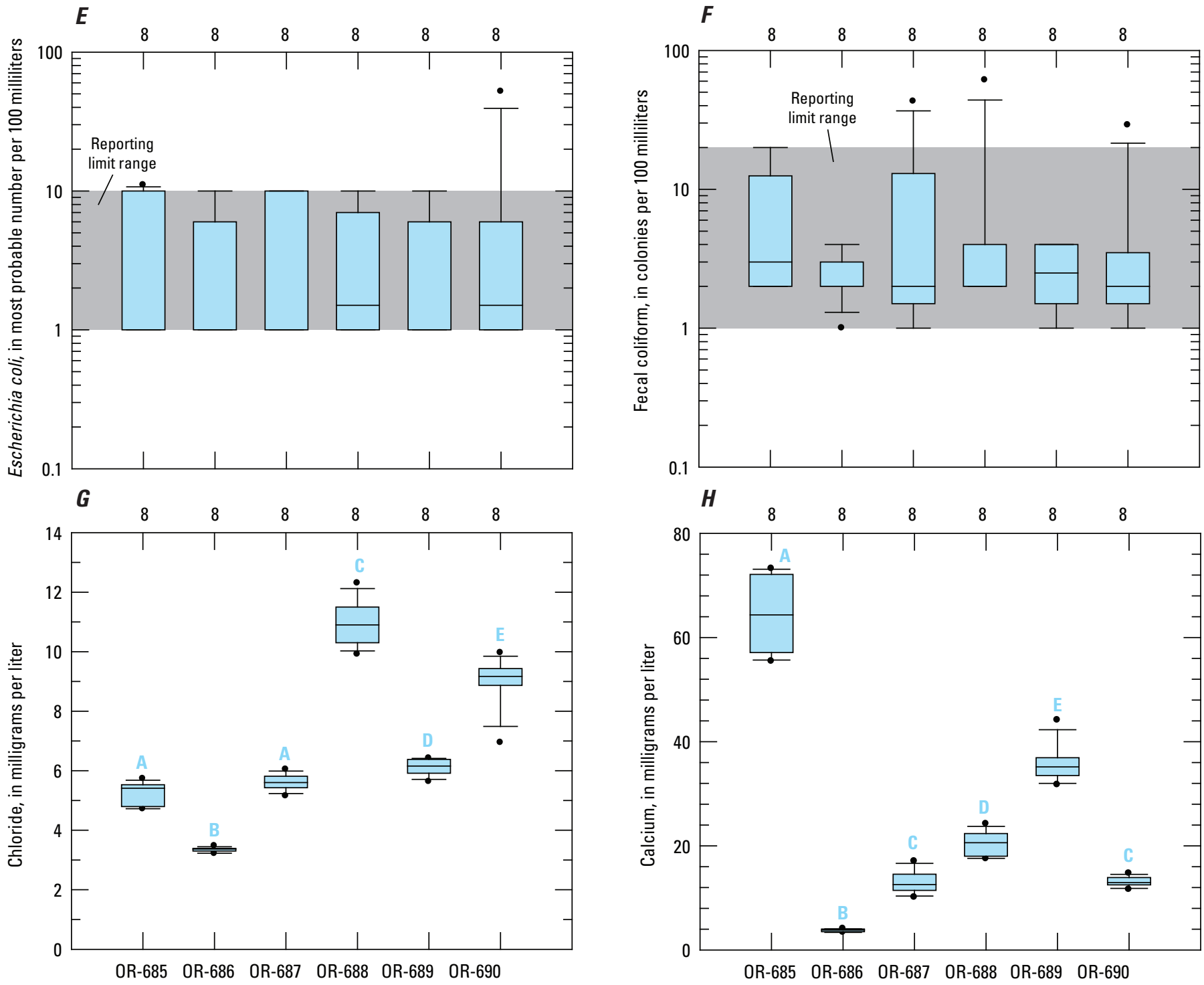

\section{EXPLANATION}

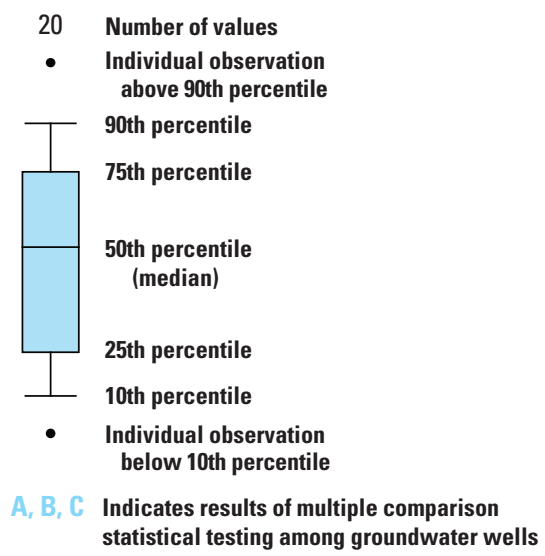

Figure 12. Concentrations of $(A)$ nitrate, $(B)$ sodium, $(C)$ total nitrogen, $(D)$ total phosphorus, $(E)$ Escherichia coli, $(F)$ fecal coliform, $(G)$ chloride, $(H)$ calcium, and $(/)$ potassium in wells 0R-685, 0R-686, 0R-687, OR-688, 0R-689, and 0R-690 in Orange County, North Carolina.-Continued 


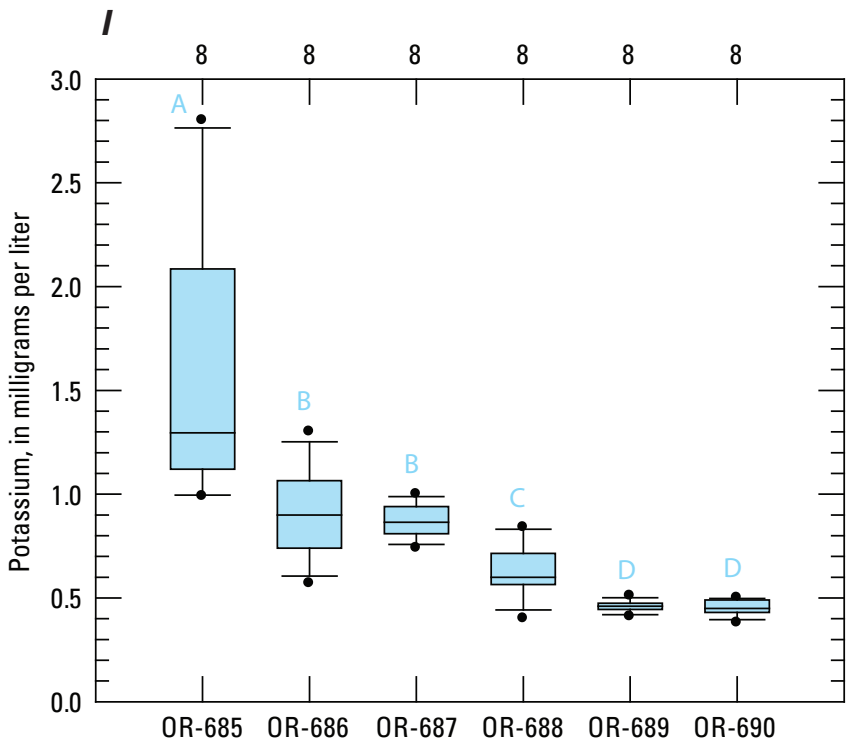

\section{EXPLANATION}

20 Number of values

- Individual observation

above 90th percentile

T 90th percentile

75th percentile

50th percentile

(median)

25th percentile

10th percentile

- Individual observation below 10th percentile

A, B, C Indicates results of multiple comparison statistical testing among groundwater wells

Figure 12. Concentrations of $(A)$ nitrate, $(B)$ sodium, $(C)$ total nitrogen, $(D)$ total phosphorus, $(E)$ Escherichia coli, $(F)$ fecal coliform, $(G)$ chloride, $(H)$ calcium, and $(/)$ potassium in wells 0R-685, 0R-686, 0R-687, 0R-688, 0R-689, and 0R-690 in Orange County, North Carolina.-Continued 
Table 16. Results of multiple comparison statistical testing for selected constituent concentrations among the six groundwater monitoring wells in Orange County, North Carolina.

[Red shaded cell - no statistical difference between wells for the constituent at 95\% confidence level]

\begin{tabular}{lcccccc}
\hline \multirow{2}{*}{ Well name } & \multicolumn{6}{c}{ Nitrate concentration statistical difference } \\
\cline { 2 - 7 } & OR-685 & OR-686 & OR-687 & OR-688 & OR-689 & OR-690 \\
\hline OR-685 & & Yes & Yes & Yes & No & No \\
OR-686 & Yes & & Yes & Yes & Yes & Yes \\
OR-687 & Yes & Yes & & No & Yes & Yes \\
OR-688 & Yes & Yes & No & & Yes & Yes \\
OR-689 & No & Yes & Yes & Yes & & Yes \\
OR-690 & No & Yes & Yes & Yes & Yes &
\end{tabular}

\begin{tabular}{lcccccc}
\hline \multirow{2}{*}{ Well name } & \multicolumn{5}{c}{ Total nitrogen concentration statistical difference } \\
\cline { 2 - 7 } & OR-685 & OR-686 & OR-687 & OR-688 & OR-689 & OR-690 \\
\hline OR-685 & & Yes & Yes & Yes & No & No \\
OR-686 & Yes & & Yes & Yes & Yes & Yes \\
OR-687 & Yes & Yes & & No & Yes & Yes \\
OR-688 & Yes & Yes & No & & Yes & Yes \\
OR-689 & No & Yes & Yes & Yes & & Yes \\
OR-690 & No & Yes & Yes & Yes & Yes & \\
& & & & & &
\end{tabular}

\begin{tabular}{lcccccc}
\hline \multirow{2}{*}{ Well name } & \multicolumn{5}{c}{ Total phosphorus concentration statistical difference } \\
\cline { 2 - 7 } & OR-685 & OR-686 & OR-687 & OR-688 & OR-689 & OR-690 \\
\hline OR-685 & & Yes & Yes & Yes & Yes & Yes \\
OR-686 & Yes & & No & Yes & Yes & Yes \\
OR-687 & Yes & No & & Yes & Yes & Yes \\
OR-688 & Yes & Yes & Yes & & No & No \\
OR-689 & Yes & Yes & Yes & No & & No \\
OR-690 & Yes & Yes & Yes & No & No & \\
& & & & & &
\end{tabular}

\begin{tabular}{lcccccc}
\hline \multirow{2}{*}{ Well name } & \multicolumn{6}{c}{ Chloride concentration statistical difference } \\
\cline { 2 - 7 } & OR-685 & OR-686 & OR-687 & OR-688 & OR-689 & 0R-690 \\
\hline OR-685 & & Yes & No & Yes & Yes & Yes \\
OR-686 & Yes & & Yes & Yes & Yes & Yes \\
OR-687 & No & Yes & & Yes & Yes & Yes \\
OR-688 & Yes & Yes & Yes & & Yes & Yes \\
OR-689 & Yes & Yes & Yes & Yes & & Yes \\
OR-690 & Yes & Yes & Yes & Yes & Yes & \\
& & & & & & \\
\hline
\end{tabular}


Table 16. Results of multiple comparison statistical testing for selected constituent concentrations among the six groundwater monitoring wells in Orange County, North Carolina.-Continued

[Red shaded cell - no statistical difference between wells for the constituent at 95\% confidence level]

\begin{tabular}{lcccccc}
\hline \multirow{2}{*}{ Well name } & \multicolumn{7}{c}{ Calcium concentration statistical difference } \\
\cline { 2 - 7 } & OR-685 & OR-686 & OR-687 & OR-688 & OR-689 & OR-690 \\
\hline OR-685 & & Yes & Yes & Yes & Yes & Yes \\
OR-686 & Yes & & Yes & Yes & Yes & Yes \\
OR-687 & Yes & Yes & & Yes & Yes & No \\
OR-688 & Yes & Yes & Yes & & Yes & Yes \\
OR-689 & Yes & Yes & Yes & Yes & & Yes \\
OR-690 & Yes & Yes & No & Yes & Yes & \\
& & & & & &
\end{tabular}

\begin{tabular}{lcccccc}
\hline \multirow{2}{*}{ Well name } & \multicolumn{7}{c}{ Potassium concentration statistical difference } \\
\cline { 2 - 7 } & OR-685 & OR-686 & OR-687 & OR-688 & OR-689 & OR-690 \\
\hline OR-685 & & Yes & Yes & Yes & Yes & Yes \\
OR-686 & Yes & & No & Yes & Yes & Yes \\
OR-687 & Yes & No & & Yes & Yes & Yes \\
OR-688 & Yes & Yes & Yes & & Yes & Yes \\
OR-689 & Yes & Yes & Yes & Yes & & No \\
OR-690 & Yes & Yes & Yes & Yes & No & \\
& & & & & &
\end{tabular}

\begin{tabular}{lcccccc}
\hline \multirow{2}{*}{ Well name } & \multicolumn{7}{c}{ Sodium concentration statistical difference } \\
\cline { 2 - 7 } & OR-685 & OR-686 & OR-687 & OR-688 & OR-689 & OR-690 \\
\hline OR-685 & & Yes & Yes & Yes & Yes & Yes \\
OR-686 & Yes & & No & No & No & Yes \\
OR-687 & Yes & No & & No & Yes & Yes \\
OR-688 & Yes & No & No & & Yes & Yes \\
OR-689 & Yes & No & Yes & Yes & & Yes \\
OR-690 & Yes & Yes & Yes & Yes & Yes & \\
\hline
\end{tabular}


Table 17. Median concentrations of U.S. Environmental Protection Agency-listed contaminants with ceiling concentrations for landapplied biosolids (arsenic, cadmium, chromium, copper, lead, mercury, molybdenum, nickel, selenium, and zinc) and selected nutrients (nitrate, total nitrogen, and total phosphorus) detected in groundwater samples collected at six monitoring wells in Orange County, North Carolina.

$[\mu \mathrm{g} / \mathrm{L}$, micrograms per liter; mg/L, milligrams per liter; $<$, less than; gray shaded cells are background wells $]$

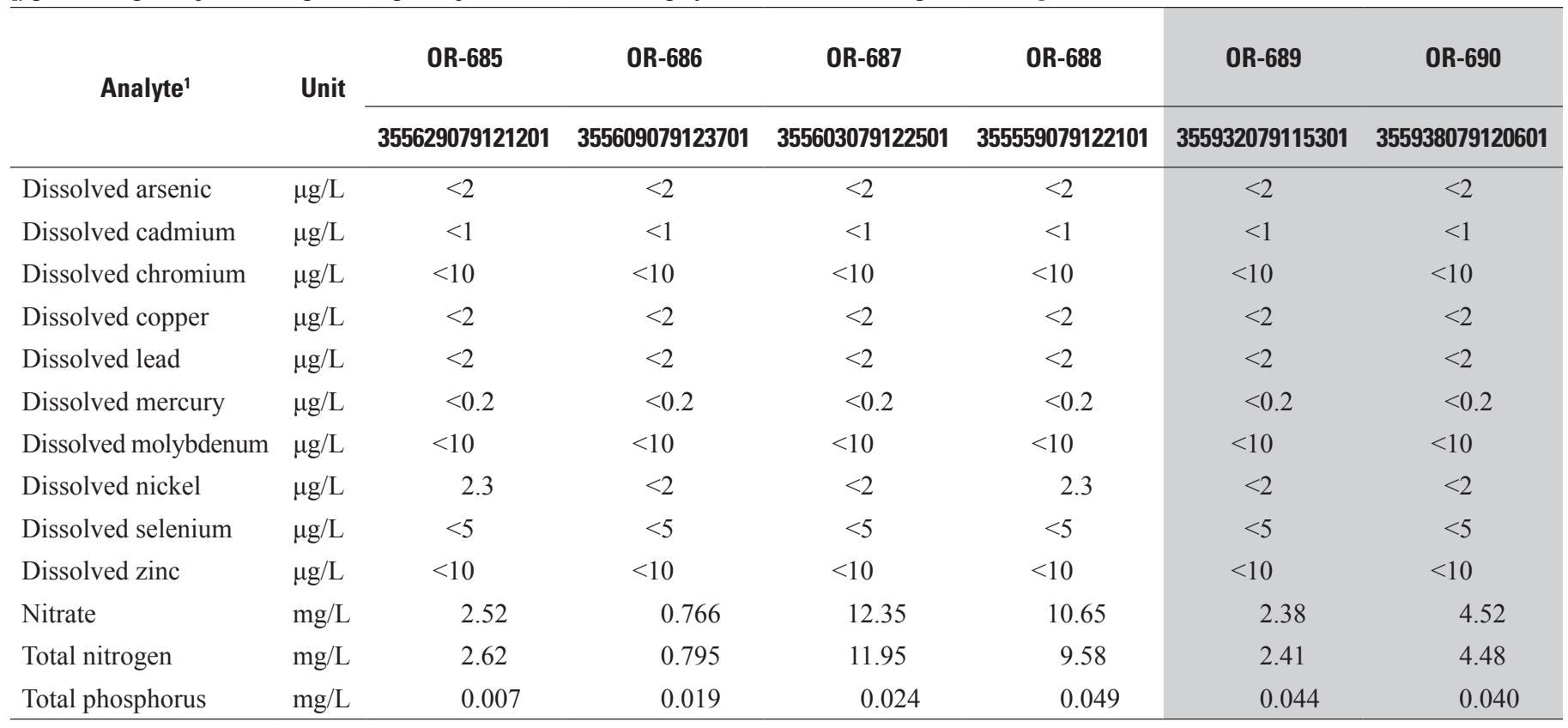

${ }^{1}$ For analyte datasets including censored value(s) at a single censoring level, the rank method was used to compute the median (Bonn, 2008). Methods described by Helsel and Hirsch (1992) were used to compute the median for analyte datasets consisting of only multiply censored values.

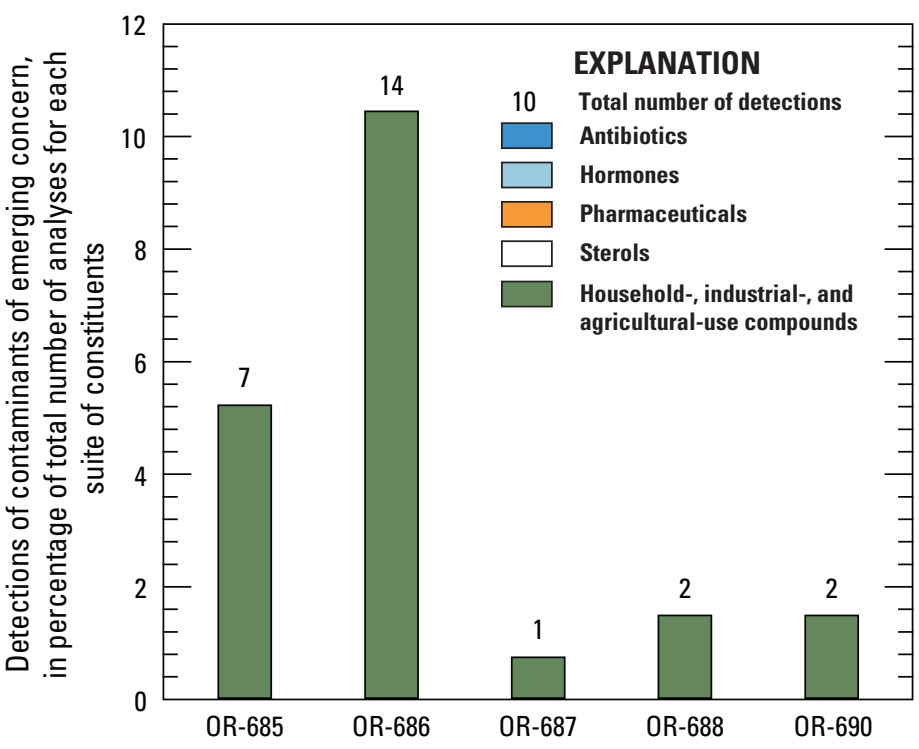

Figure 13. Percentage of detections within the various analytical suites of contaminants of emerging concern in shallow groundwater samples from five monitoring wells in Orange County, North Carolina. 
Table 18. Concentrations of contaminants of emerging concern detected in groundwater samples collected at five monitoring wells in Orange County, North Carolina.

$[\mu \mathrm{g} / \mathrm{L}$, micrograms per liter; $\mathrm{ng} / \mathrm{L}$, nanograms per liter; $<$, less than; E, estimated concentration; $\mathrm{V}$, analyte detected in laboratory blank; gray shaded cells indicate analyte detection]

\begin{tabular}{|c|c|c|c|c|c|c|}
\hline \multirow[t]{2}{*}{ Contaminants of emerging concern } & \multirow[t]{2}{*}{ Unit } & $\begin{array}{c}\text { OR-685 } \\
355629079121201 \\
\end{array}$ & $\begin{array}{c}\text { OR-686 } \\
355609079123701\end{array}$ & $\begin{array}{c}\text { OR-687 } \\
355603079122501\end{array}$ & $\begin{array}{c}\text { OR-688 } \\
355559079122101\end{array}$ & $\begin{array}{c}\text { OR-690 } \\
355938079120601 \\
\end{array}$ \\
\hline & & $12 / 13 / 11$ & $12 / 14 / 11$ & $12 / 14 / 11$ & $12 / 13 / 11$ & $12 / 12 / 11$ \\
\hline 1-Methylnaphthalene & $\mu \mathrm{g} / \mathrm{L}$ & $<0.04$ & 0.01 & $<0.04$ & $<0.04$ & $<0.04$ \\
\hline 2,6-Dimethylnaphthalene & $\mu \mathrm{g} / \mathrm{L}$ & $<0.04$ & 0.02 & $<0.04$ & $<0.04$ & $<0.04$ \\
\hline bis(2-Ethylhexyl) phthalate & $\mu \mathrm{g} / \mathrm{L}$ & $<2$ & 2 & $<2$ & $<2$ & $<2$ \\
\hline Bisphenol A & $\mu \mathrm{g} / \mathrm{L}$ & E4.41 & 4.97 & $0.11^{\mathrm{a}}$ & $0.11^{\mathrm{a}}$ & $0.21^{\mathrm{a}}$ \\
\hline Bisphenol A & $\mathrm{ng} / \mathrm{L}$ & 5,180 & 5,840 & $<100$ & $<100$ & $118^{\mathrm{a}}$ \\
\hline Camphor & $\mu \mathrm{g} / \mathrm{L}$ & $<0.08$ & 1.08 & $<0.08$ & $<0.08$ & $<0.08$ \\
\hline Prometon & $\mu \mathrm{g} / \mathrm{L}$ & $<0.16$ & $<0.16$ & $<0.16$ & 0.06 & $<0.16$ \\
\hline Tetrachloroethylene & $\mu \mathrm{g} / \mathrm{L}$ & $<0.16$ & E0.004 & $<0.16$ & $<0.16$ & $<0.16$ \\
\hline Bromoform & $\mu \mathrm{g} / \mathrm{L}$ & E0.01 & 0.01 & $<0.16$ & $<0.16$ & $<0.16$ \\
\hline Tributyl phosphate & $\mu \mathrm{g} / \mathrm{L}$ & $<0.064$ & 0.018 & $<0.064$ & $<0.064$ & $<0.064$ \\
\hline Tris(2-chloroethyl)phosphate & $\mu \mathrm{g} / \mathrm{L}$ & E0.03 & E0.02 & $<0.16$ & $<0.16$ & $<0.16$ \\
\hline Tris(dichloroisopropyl)phosphate & $\mu \mathrm{g} / \mathrm{L}$ & E0.09 & $<0.32$ & $<0.32$ & $<0.32$ & 0.1 \\
\hline
\end{tabular}

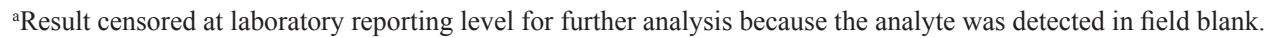

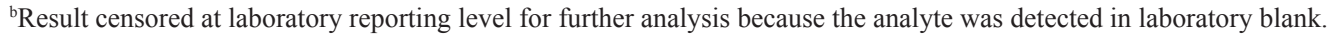

\section{Surface Water}

The subsequent sections summarize measured surfacewater quantity and quality at the three monitoring sitesCO-SW1, CO-SW5, and CA-SW1 (table 1). The information provides the framework for characterizing and comparing constituent concentrations, and loads and yields in agricultural watersheds with and without land-applied biosolids.

\section{Discharge}

As discussed previously, discharge was recorded at the three surface-water monitoring sites at 5- (Collins Creek sites) to 15-minute (Cane Creek) intervals throughout the study period. As illustrated in figure 14, water-quality samples collected from the three surface-water monitoring sites covered the range of streamflow that occurred during the study period.

The compiled streamflow data were used to determine streamflow characteristics (annual streamflows, annual streamflow yields, and baseflow index [BFI]) for use in the evaluations of the nutrient and bacteria yields among the monitoring sites. Streamflow yields for the study period were computed by dividing streamflow by watershed drainage area to normalize the effects of large differences in drainage areas among the study sites (table 19). 


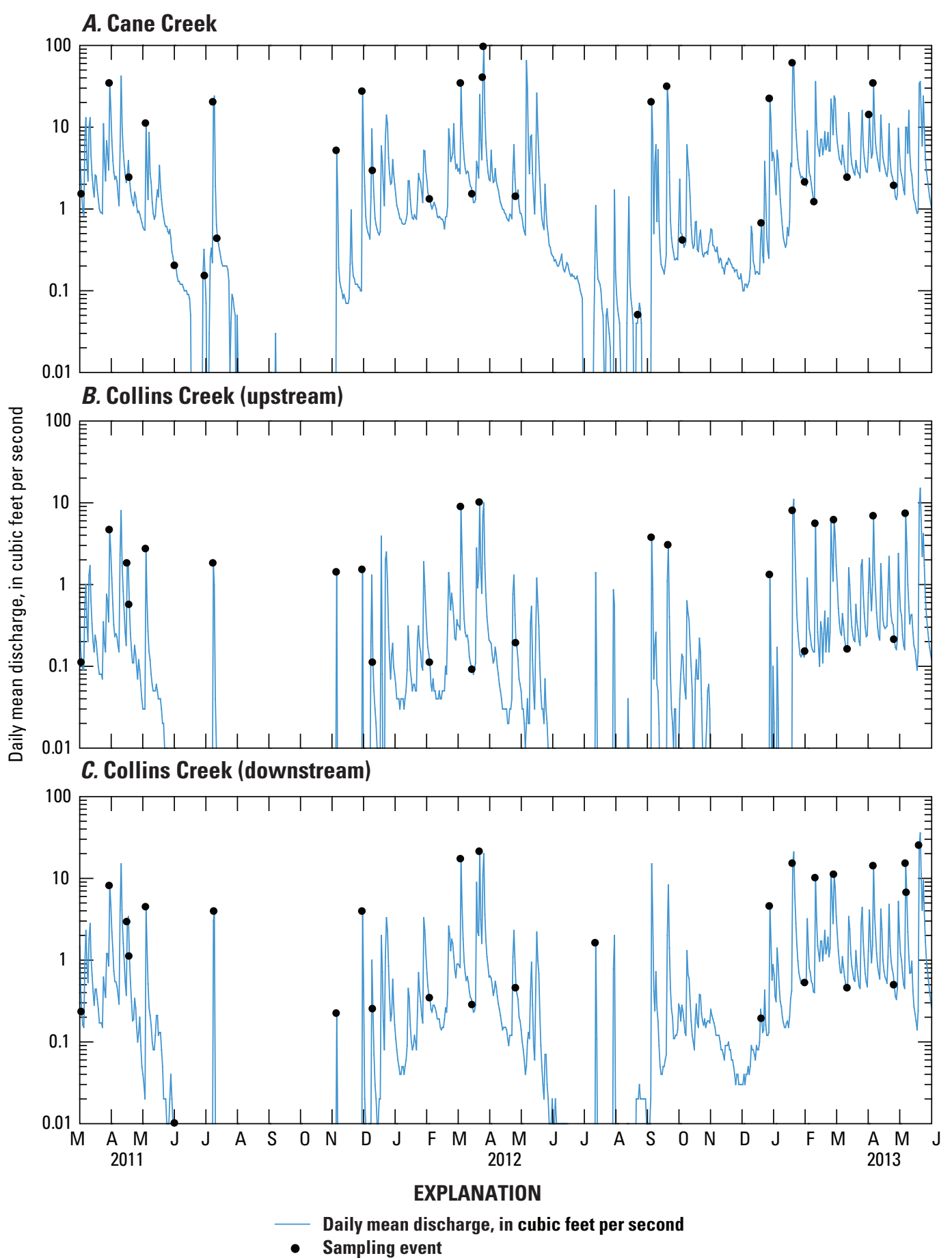

Figure 14. Daily mean discharge hydrograph and stream sampling events for streamgages and water-quality monitoring sites at (A) Cane Creek (02096846, site ID CA-SW1), (B) Collins Creek (upstream) (0209691590, site ID CO-SW1), and (C) Collins Creek (downstream) (0209691611, site ID CO-SW5), in Orange County, North Carolina. 
Table 19. Summary of streamflow data collected for the study period March 1, 2011-May 31, 2013, at the monitoring sites on Cane Creek and Collins Creek in Orange County, North Carolina.

(USGS, U.S. Geological Survey; $\mathrm{mi}^{2}$, square miles; SP, study period; DMV ft³/s, daily mean value of flow in cubic feet per second; Mgal, million gallons)

\begin{tabular}{|c|c|c|c|c|c|c|}
\hline $\begin{array}{l}\text { USGS } \\
\text { station } \\
\text { number }\end{array}$ & $\begin{array}{l}\text { USGS station } \\
\text { name }\end{array}$ & $\begin{array}{l}\text { Study site } \\
\text { ID (loca- } \\
\text { tions in } \\
\text { figures } 2 \\
\text { and 3) }\end{array}$ & $\begin{array}{c}\text { Drainage } \\
\text { area } \\
\left(\mathrm{mi}^{2}\right)\end{array}$ & $\begin{array}{c}\text { Total } \\
\text { streamflow } \\
\left.\text { (DMV ft } \mathrm{ft}^{3} / \mathrm{s}\right)\end{array}$ & $\begin{array}{c}\text { Total } \\
\text { streamflow } \\
\text { (Mgal) }\end{array}$ & $\begin{array}{c}\text { Total } \\
\text { streamflow } \\
\text { yield } \\
\left(\mathrm{Mgal} / \mathrm{mi}^{2}\right)\end{array}$ \\
\hline 0209691590 & $\begin{array}{l}\text { Collins Creek above SR } 1006 \text { near } \\
\text { White Cross, NC }\end{array}$ & CO-SW1 & 1.7 & 314.43 & 203.22 & 117.47 \\
\hline 0209691611 & $\begin{array}{l}\text { Collins Creek at Hwy } 54 \text { near } \\
\text { White Cross, NC }\end{array}$ & CO-SW5 & 3.2 & 692.24 & 447.41 & 136.40 \\
\hline 02096846 & Cane Creek near Orange Grove & CA-SW1 & 7.5 & $2,365.87$ & $1,529.10$ & 202.26 \\
\hline
\end{tabular}

\section{Water Quality}

A detailed summary of the analytical results for the surface-water samples collected at all sites is presented in appendix table 2-4. The water type in terms of cations and anions for storm samples at the three monitoring sites are similar (fig. 15B). Baseflow water types at site CO-SW5 differed from the baseflow water types at sites CO-SW1 and CA-SW1 (fig. 15A). Baseflow at site CA-SW1 and the CO-SW1 site have similar relative abundance of cations whereas the CO-SW5 site has more sodium plus potassium and less calcium. The anions are similar between Cane Creek and the downstream Collins Creek site whereas the upstream Collins Creek site has somewhat more chloride and nitrate plus nitrite and less sulfate. Overall, the water types at the three monitoring sites during baseflow conditions are roughly similar. During storm conditions, the water type of the three monitoring sites become more similar especially in relation to cation composition (fig. 15B). Overall, water types do not exhibit a great amount of change between baseflow and stormwater runoff conditions.

\section{Comparisons of Surface-Water Quality}

Water-quality laboratory results are used herein to characterize surface-water conditions in agricultural watersheds with and without land-applied biosolids. Comparisons of surface-water inorganic and organic constituent concentrations, nutrient and bacteria loadings and yields, benthic invertebrate surveys, and the presence of genetic biomarkers are used in the characterization. The comparisons focus on the primary macronutrients (nitrogen, phosphorus, and potassium), selected secondary macronutrients (calcium), and chloride and sodium, which are found in human biosolids, animal manure, and commercial fertilizers commonly used in North Carolina for growing crops (Zublena and others, 1991; Tucker, 1999). These characterizations and comparisons provide insight into (1) the differences in the amount of monitored constituents that are being delivered to surface water from agricultural fields with and without land-applied biosolids, and (2) the potential effect of land-applied biosolids on surface-water quality. 
$\boldsymbol{A}$
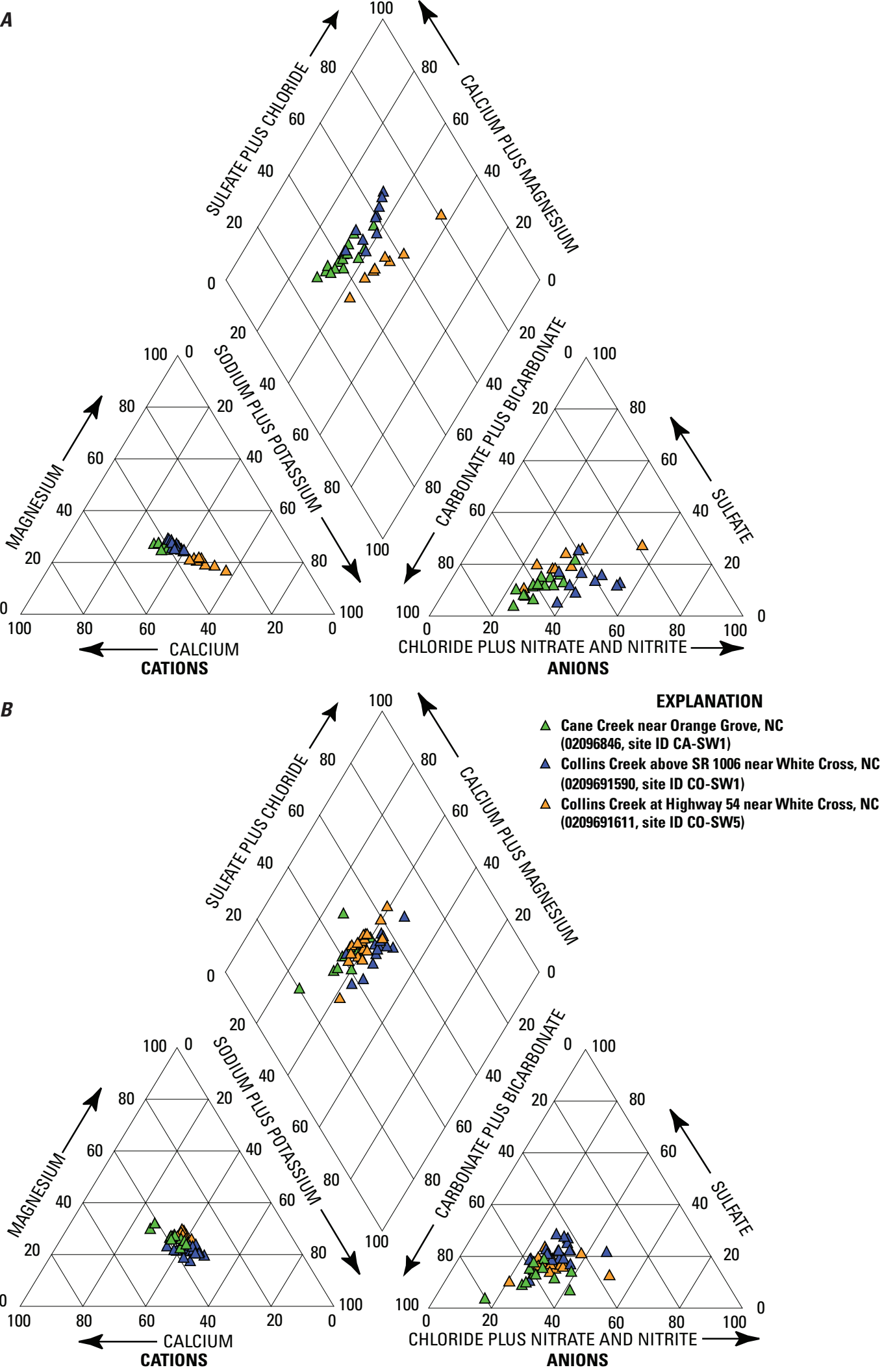

Figure 15. Water chemistry data from December 2010 to May 2013 displayed on a tri-linear Piper diagram from streamgages and surface-water quality monitoring sites during $(A)$ baseflow conditions and $(B)$ stormflow conditions in the Cane Creek and Collins Creek watersheds in Orange County, North Carolina. 
Summary and Statistical Analysis of Surface-water Constituent Concentrations

Statistical comparison testing was conducted to determine if there were statistically significant differences in surfacewater concentrations of nutrients, bacteria, and selected ions between baseflow and stormwater runoff conditions, between winter/spring and summer/fall seasons at each monitoring site, and among the three monitoring sites. Statistical analyses for the metals with EPA ceiling concentrations for land-applied biosolids (see appendix table 2-4) were not performed because these compounds either were detected in less than eight baseflow and (or) storm samples at a site or all of the concentrations were estimated to be less than the LT-MDL.

With the exception of nitrate and TN concentrations at the Collins Creek site downstream from the biosolids application fields (CO-SW5), nutrient concentrations generally were higher in storm samples than baseflow samples (fig. 16A-D). Although the maximum and range of nitrate concentrations for storm samples were larger than baseflow concentrations at the Cane Creek background site (CA-SW1) (fig. 16A), the storm and baseflow nitrate concentrations were not statistically different ( $\mathrm{p}=0.552)$. The maximum, range, and median nitrate concentrations for storm samples were larger than baseflow concentrations at the Collins Creek site upstream from the biosolids application fields (CO-SW1) (fig. 16A), and the storm concentrations were statistically higher than baseflow concentrations $(\mathrm{p}=0.011)$. In contrast, the maximum, range, and median baseflow nitrate concentrations were all appreciably higher than the storm concentrations at the CO-SW5 site, and the baseflow concentrations were statistically higher than the storm concentrations $(\mathrm{p}=0.003)$. This indicates an appreciable groundwater nitrate contribution (fig. 12A) to the CO-SW5 site, which is downstream from the agricultural fields that receive land-applied biosolids. Concentrations of organic nitrogen $(p<0.001)$ and TP $(p<0.001)$ were statistically higher in storm samples at all three sites (fig. 16B, D), likely reflecting increased input of organic material and particle-associated phosphorus during storms. Total nitrogen concentrations were statistically higher in storm samples at the CA-SW1 $(p<0.001)$ and CO-SW1 $(p<0.001)$ sites, but there is no statistical difference between baseflow and storm samples at the CO-SW5 site ( $\mathrm{p}=0.603$ ) (fig. 16C), which is directly related to the relatively high baseflow nitrate concentrations at CO-SW5. Concentrations of E. coli $(\mathrm{p}<0.001)$ and fecal coliform $(p<0.001)$ bacteria were statistically higher by orders of magnitude in storm samples at all three sites compared to baseflow samples (fig. $16 E, F)$. Calcium ( $\mathrm{p}=0.008$ ), chloride $(\mathrm{p}<0.001)$, and sodium $(\mathrm{p}<0.001)$ concentrations were all statistically higher in baseflow samples than storm samples at all three sites (fig. 16G, $H$, and $J$ ), although potassium concentrations were statistically higher $(\mathrm{p}<0.001)$ in storm samples than baseflow samples for all three sites (fig. 16I). Finally, no boxplots are shown for metals with EPA ceiling concentrations for biosolids because detections were too infrequent in the stream samples. Laboratory results for all constituents are presented for water-quality samples collected at all six surface-water sites in appendix table 2-4.

Surface-water sample results from the three monitoring sites were grouped by season (winter/spring and summer/fall) for analysis to determine if there were statistically significant variations between the seasonal groupings at the three monitoring sites. Given the relatively few samples collected in the summer and fall seasons during the study because of dry conditions, the grouping of multiple seasons was required to have an adequate number of samples in the summer/fall to conduct the statistical analysis. There were no statistically significant differences in concentrations between winter/ spring and summer/fall for nitrate, organic nitrogen, $\mathrm{TN}$, and calcium (fig. 17). Concentrations of E. coli and fecal coliform bacteria, TP, and potassium were higher and statistically different in the summer/fall than in the winter/spring (fig. 17). The results for bacteria are likely related to warmer water temperatures and lower flow conditions, and the results for phosphorus and potassium are likely related to the higher intensity rainfall that typically occurs during the summer/fall season, which tends to cause more erosion and mobilization of sediment-bound phosphorus and potassium. To support this hypothesis, potassium is the only cation that had higher concentrations during storms relative to baseflow (fig. 16I). Alternatively, concentrations of chloride and sodium were higher and statistically different in the winter/spring than in the summer/fall, which may in part be related to the use of deicers, but most likely is related to the fact that baseflow was the highest during the winter/spring, and concentrations of chloride and sodium concentrations were highest during baseflow (fig. 17).

Baseflow nitrate concentrations at CO-SW5 were higher and statistically different than those for CA-SW1 and CO-SW1, and baseflow nitrate concentrations at CA-SW1 were higher and statistically different than those for CO-SW1 (fig. 16A). This is consistent with the elevated groundwater nitrate concentrations observed in the wells adjacent to the biosolids application fields (fig. 12) given the relatively large groundwater contribution to the total streamflow during baseflow conditions. Storm nitrate concentrations at CO-SW5 were higher and statistically different than those at CA-SW1 and CO-SW1, and storm nitrate concentrations at CA-SW1 were higher and statistically different than those at CO-SW1 (fig. 16A). Baseflow organic nitrogen concentrations at CA-SW1 were lower and statistically different than those at CO-SW1 and CO-SW5, and there is no statistical difference between baseflow concentrations at CO-SW1 and CO-SW5 (fig. 16B). Storm organic nitrogen concentrations at CA-SW1 were higher and statistically different than those at CO-SW1, and there is no statistical difference in storm concentrations between CO-SW5 and CA-SW1 nor between CO-SW5 and CO-SW1 (fig. 16B). Total nitrogen concentrations for baseflow samples at CO-SW5 were higher and statistically different than those at CA-SW1 and CO-SW1, and there is no statistical difference between baseflow concentrations at CA-SW1 and CO-SW1 (fig. 16C). Total nitrogen 

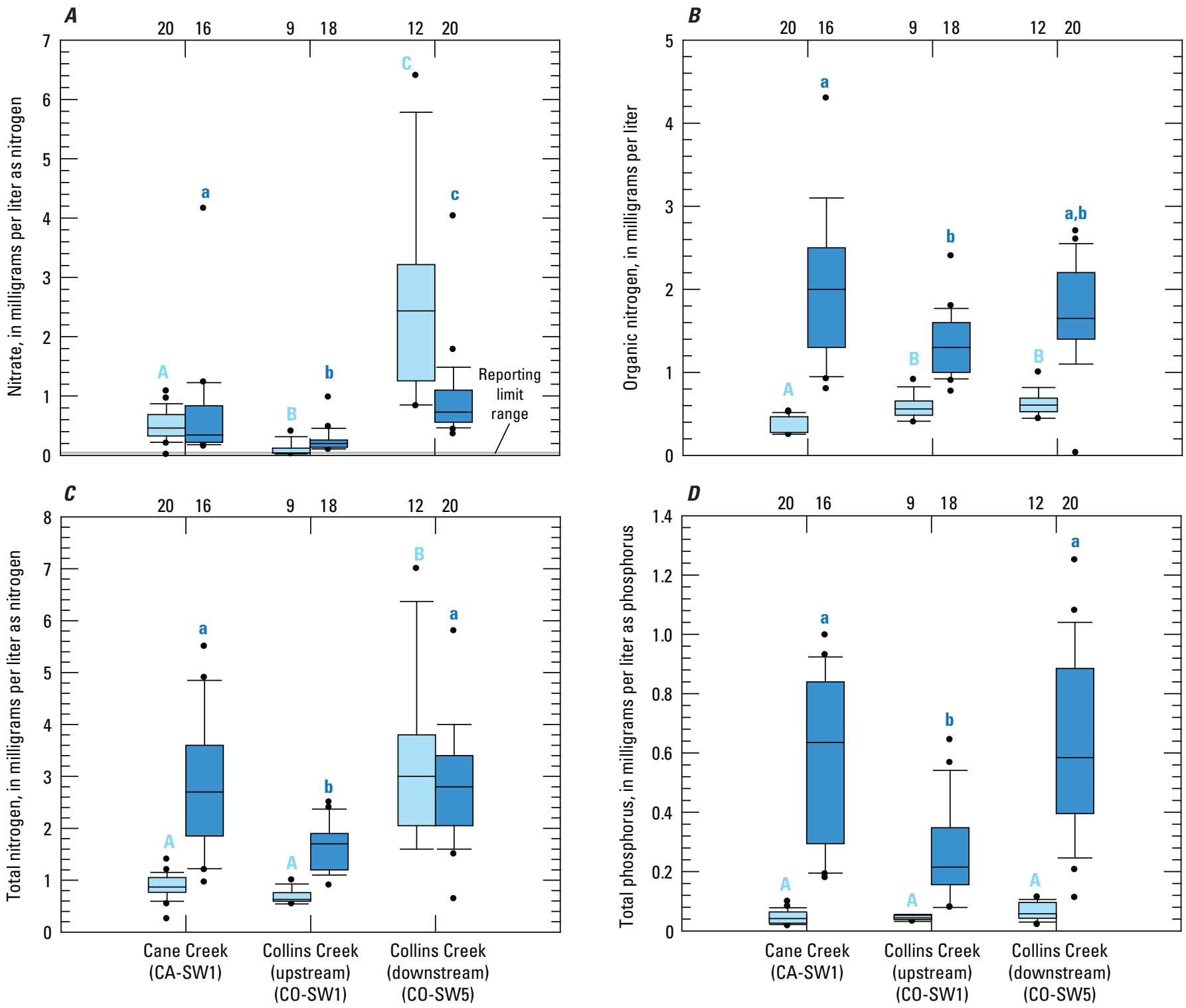

\section{EXPLANATION}

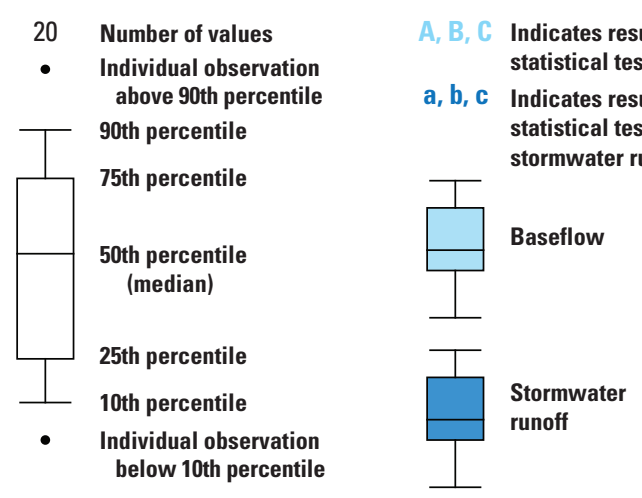

Figure 16. (A) Nitrate, $(B)$ organic nitrogen, $(C)$ total nitrogen, $(D)$ total phosphorus, $(E)$ Escherichia coli bacteria, $(F)$ fecal coliform bacteria, $(G)$ chloride, $(H)$ calcium, $(/)$ potassium, and $(J)$ sodium concentrations in Cane and Collins Creeks, North Carolina (boxplots with the same letter-A, B, C, a, b, C- indicate no statistical difference at the 95 percent confidence level). 

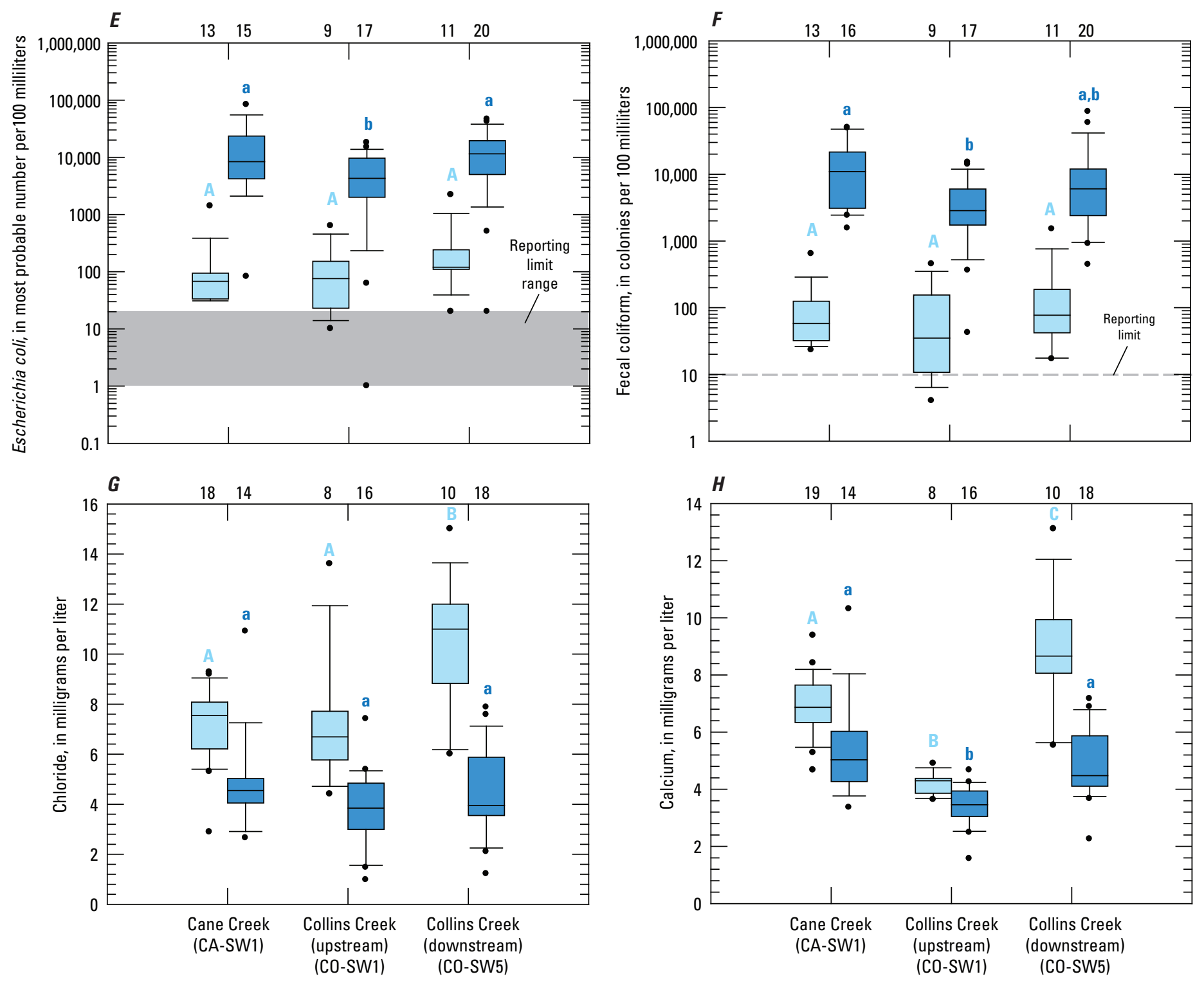

\section{EXPLANATION}
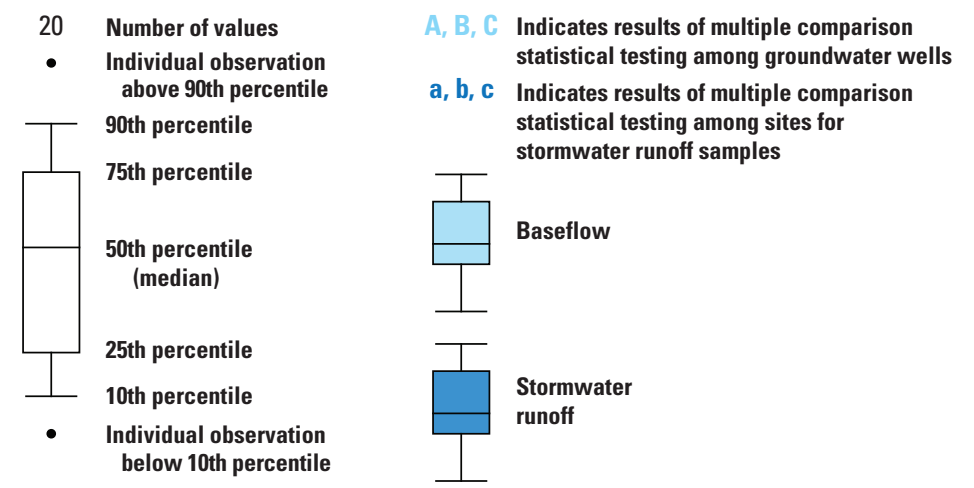

Figure 16. $(A)$ Nitrate, $(B)$ organic nitrogen, $(C)$ total nitrogen, $(D)$ total phosphorus, $(E)$ Escherichia coli bacteria, $(A)$ fecal coliform bacteria, $(G)$ chloride, $(H)$ calcium, $(/)$ potassium, and $(J)$ sodium concentrations in Cane and Collins Creeks, North Carolina (boxplots with the same letter-A, B, C, a, b, C- indicate no statistical difference at the 95 percent confidence level).-Continued 

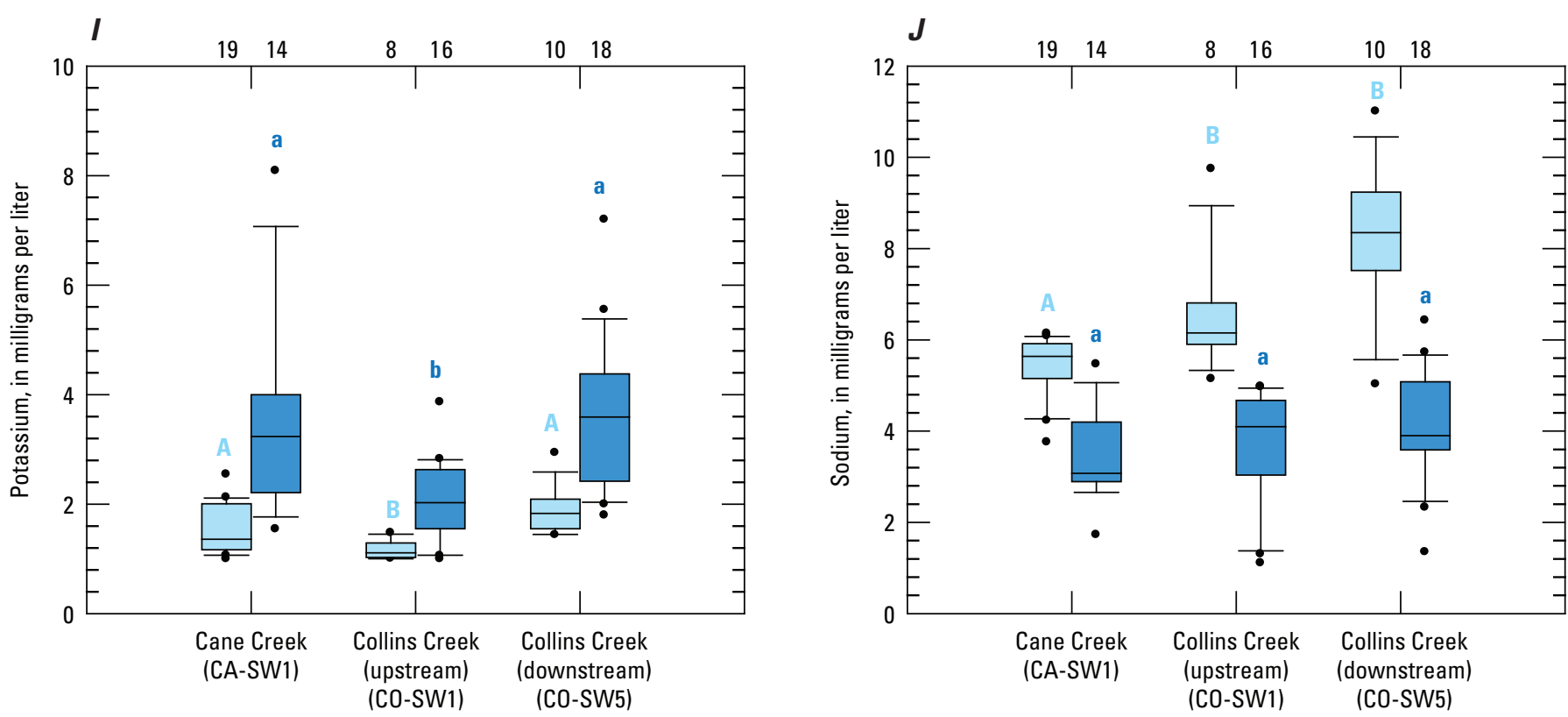

\section{EXPLANATION}
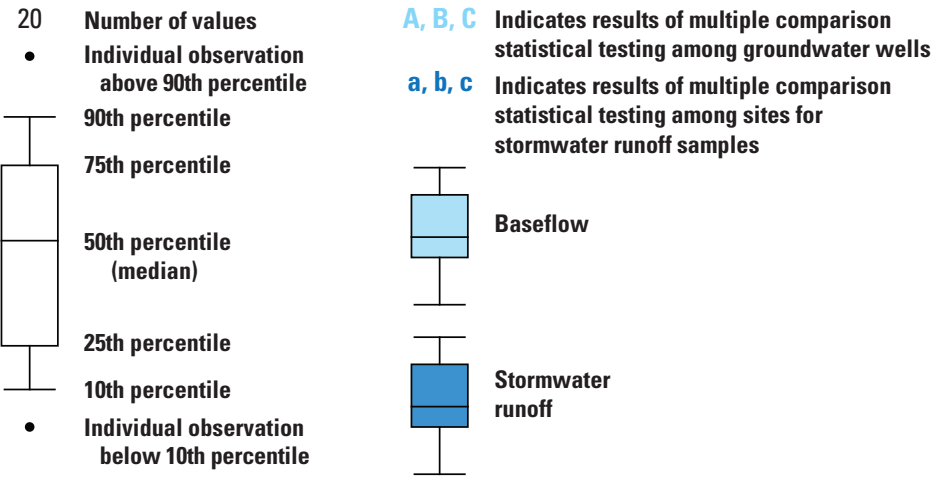

Figure 16. $(A)$ Nitrate, $(B)$ organic nitrogen, $(C)$ total nitrogen, $(D)$ total phosphorus, $(E)$ Escherichia coli bacteria, $(F)$ fecal coliform bacteria, $(G)$ chloride, ( $H$ ) calcium, (/) potassium, and (J) sodium concentrations in Cane and Collins Creeks, North Carolina (boxplots with the same letter-A, B, C, a, b, C- indicate no statistical difference at the 95 percent confidence level).-Continued 


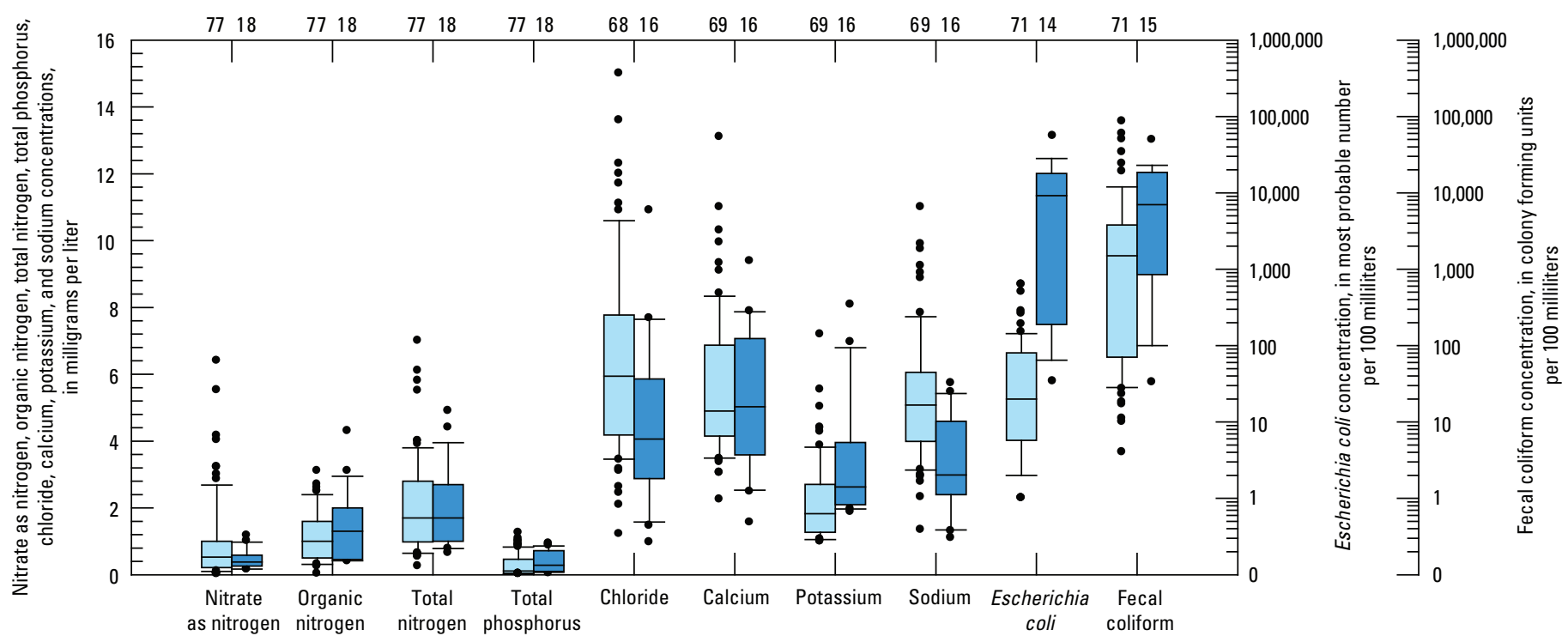

\section{EXPLANATION}

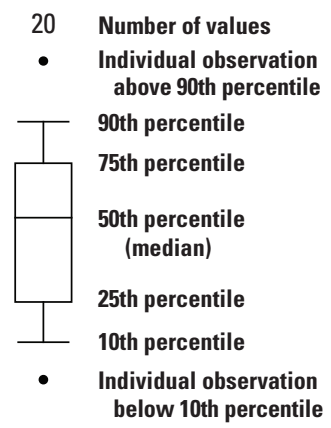

Figure 17. Concentrations of nitrate, organic nitrogen, total nitrogen, total phosphorus, chloride, calcium, potassium, sodium, Escherichia coli, and fecal coliform bacteria in surface-water quality monitoring sites in the Cane Creek and Collins Creek watersheds, Orange County, North Carolina, in the winter/spring and summer/fall seasons. 
concentrations for storm samples at CO-SW5 and CA-SW1 were higher and statistically different than at CO-SW1, and there is no statistical difference between storm samples at CO-SW5 and CA-SW1 (fig. 16C). There is no statistical difference in baseflow TP concentration among any of the three monitoring sites (fig. 16D). Total phosphorus concentrations for storm samples at CO-SW5 and CA-SW1 were higher and statistically different than at $\mathrm{CO}-\mathrm{SW} 1$, and there is no statistical difference between storm samples at CO-SW5 and CA-SW1 (fig. 16D). There is no statistical difference in baseflow $E$. coli bacteria concentrations among any of the three monitoring sites (fig. 16E). Escherichia coli bacteria storm concentrations at CA-SW1 and CO-SW5 were higher and statistically different than at CO-SW1, and there is no statistical difference between storm samples at CO-SW5 and CA-SW1 (fig. 16E). There is no statistical difference in baseflow fecal coliform bacteria concentrations among any of the three monitoring sites (fig. 16F). Fecal coliform bacteria storm concentrations at CA-SW1 were higher and statistically different than at CO-SW 1 , and there is no statistical difference in storm fecal concentrations at CO-SW5 and CA-SW1 or CO-SW5 and CO-SW1 (fig. 16F).

Chloride concentrations in baseflow samples at CO-SW5 were higher and statistically different than at CA-SW1 and CO-SW1, and there is no difference in baseflow chloride samples between CA-SW1 and CO-SW1 (fig. 16G). There is no statistical difference in storm chloride concentrations among any of the three monitoring sites (fig. 16G). Calcium concentrations for baseflow samples at CO-SW5 were higher and statistically different than those at CA-SW1 and CO-SW1, and baseflow calcium concentrations at CA-SW1 were higher and statistically different than those at CO-SW1 (fig. 16H). Calcium storm concentrations at CO-SW5 and CA-SW1 were higher and statistically different than at CO-SW1, and there is no statistical difference between storm calcium concentrations at CO-SW5 and CA-SW1 (fig. 16H). Potassium concentrations for baseflow samples at CO-SW5 and CA-SW1 were higher and statistically different than those at CO-SW1, and there is no statistical difference between baseflow potassium concentrations at CO-SW5 and CA-SW1 (fig. 16I). Potassium concentrations during storms at CO-SW5 and CA-SW1 were higher and statistically different than at $\mathrm{CO}-\mathrm{SW} 1$, and there is no statistical difference between storm potassium concentrations at CO-SW5 and CA-SW1 (fig. 16I). Sodium concentrations for baseflow samples at CO-SW5 and CO-SW1 were higher and statistically different than those at CA-SW1, and there is no statistical difference between baseflow sodium concentrations at CO-SW5 and CO-SW1 (fig. 16J). There is no statistical difference between storm sodium concentrations among the three sites (fig. 16J).

With the exception of organic nitrogen concentrations in stormwater runoff, which were the highest at site CA-SW1, constituent concentrations at the CO-SW5 site were higher and statistically different in 45 percent of the comparisons of corresponding concentrations at the other two monitoring sites that do not have land-applied biosolids in the contributing watersheds. For just the nutrient concentrations, the analytical results from the CO-SW5 site were higher and statistically different for 56 percent of the comparisons with the other two monitoring sites. A majority of the comparisons for which the CO-SW5 is higher and statistically different than the other sites were for baseflow conditions, which indicates the most significant difference among the sites, particularly between CA-SW 1 and CO-SW5, is related to the groundwater contribution.

To further evaluate any differences in the surfacewater quality in watersheds with and without land-applied biosolids, the concentrations of EPA-listed contaminants with ceiling concentrations for land-applied biosolids and nutrients in stormwater runoff sampled in at least two of the three main surface-water sites is presented in table 20 . Most of the concentrations of the constituents with EPA ceiling concentrations were less than the long-term detection limits that were established by the NCDENR water-quality laboratory that conducted the analysis of these constituents (tables 7 and 20). With the exception of nitrate in baseflow and storm samples and total nitrogen in baseflow samples, which were appreciably higher at site CO-SW5, the concentrations for all other constituents were either similar to or higher at the background site (CA-SW1) relative to site CO-SW5. Site CO-SW1 had the lowest concentrations among the three monitoring sites, although except for nitrate, the concentrations for all other constituents were similar to the other sites.

Stormwater runoff samples for three storm events that closely followed biosolids land application (table 10) were collected in the fall seasons of 2011 and 2012 and analyzed for contaminants of emerging concern (household-, industrial-, and agricultural-use compounds, sterols, pharmaceuticals, hormones, and antibiotics) at the three monitoring sites. Baseflow samples were also collected once for analysis of contaminants of emerging concern on December 20, 2010, at the CO-SW5 and CA-SW1 monitoring sites, at the Collins Creek mid-stream site (CO-SW2), and at one of the Collins Creek tributaries (CO-SW4). In addition, for the stormwater runoff samples collected at the three monitoring sites on November 29, 2011, samples for contaminants of emerging concern were also collected along Collins Creek at site $\mathrm{CO}-\mathrm{SW} 2$ and the two tributaries, $\mathrm{CO}-\mathrm{SW} 3$ and CO-SW4, as the hydrograph peak moved downstream from $\mathrm{CO}-\mathrm{SW} 1$ to CO-SW5. For comparison purposes, however, the discussion of the contaminants of emerging concern results presented herein focus only on the three monitoring sites (CA-SW1, CO-SW5, and CO-SW1) and the storm-event data that were collected on November 4, 2011, November 29, 2011, and December 26, 2012 (fig. 18; table 21). The results of all sampling events for which contaminants of emerging concern were analyzed are presented in appendix table 2-4, which provides a compilation of the analytical results for organic surface-water samples collected at all sites. 


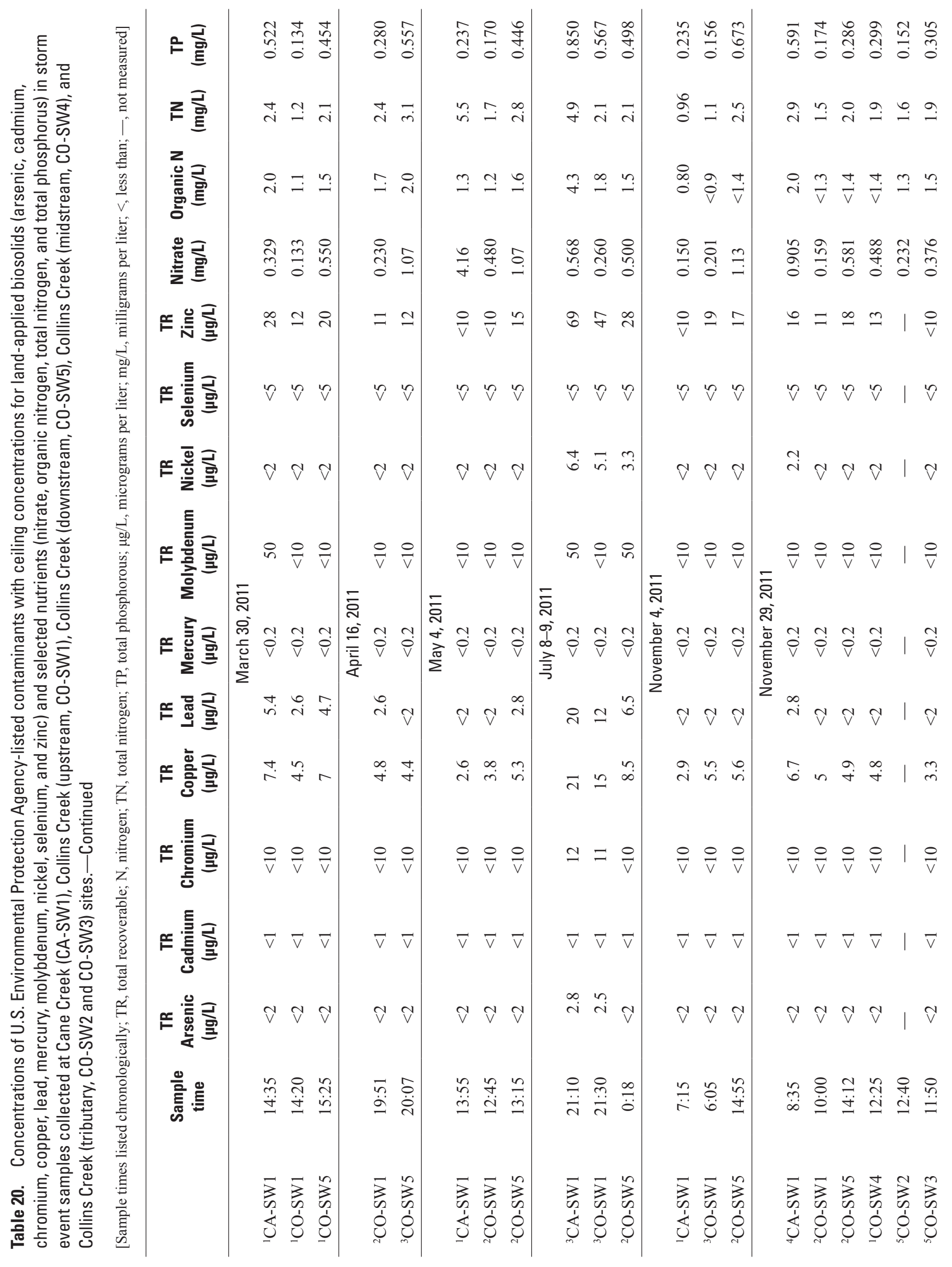




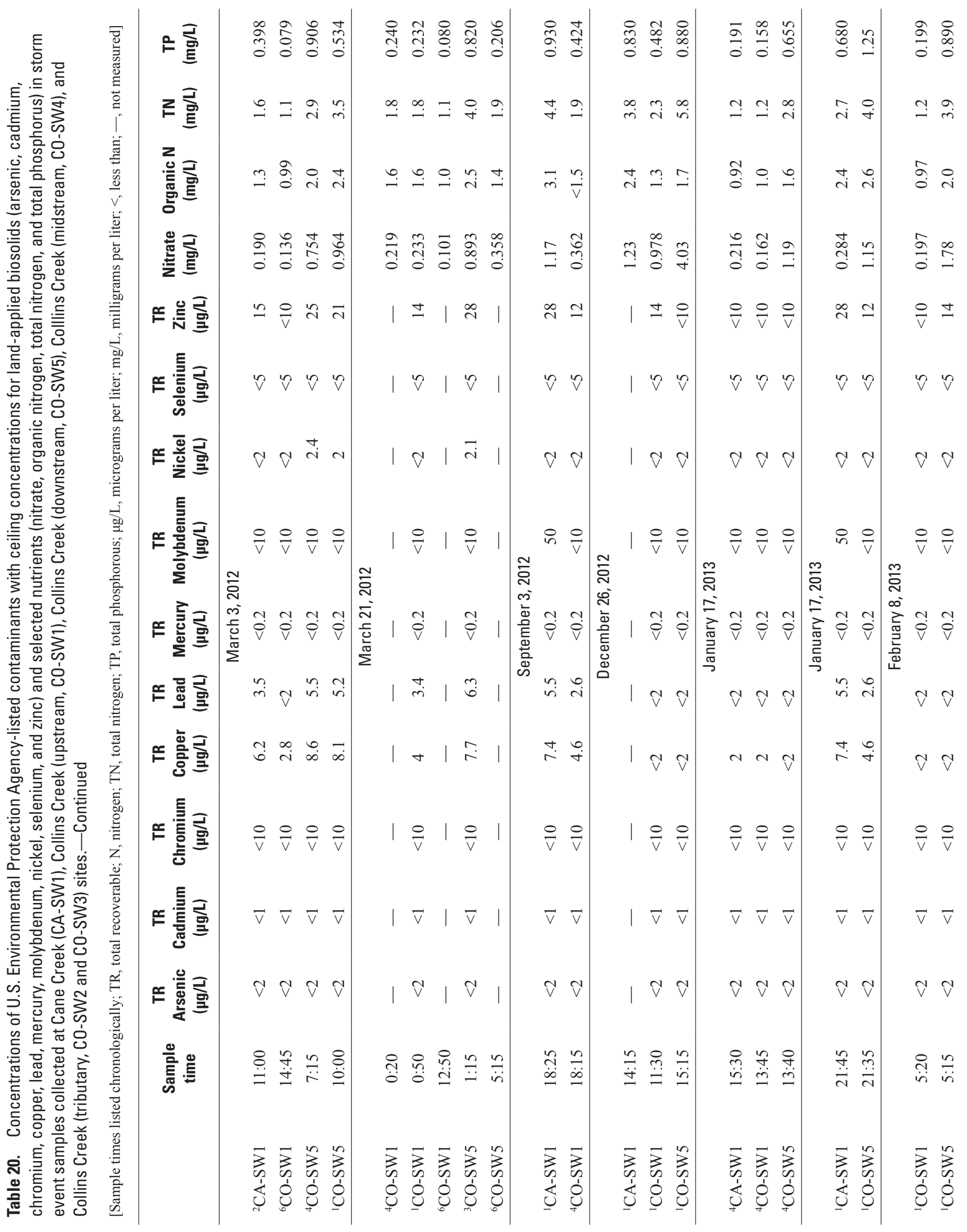




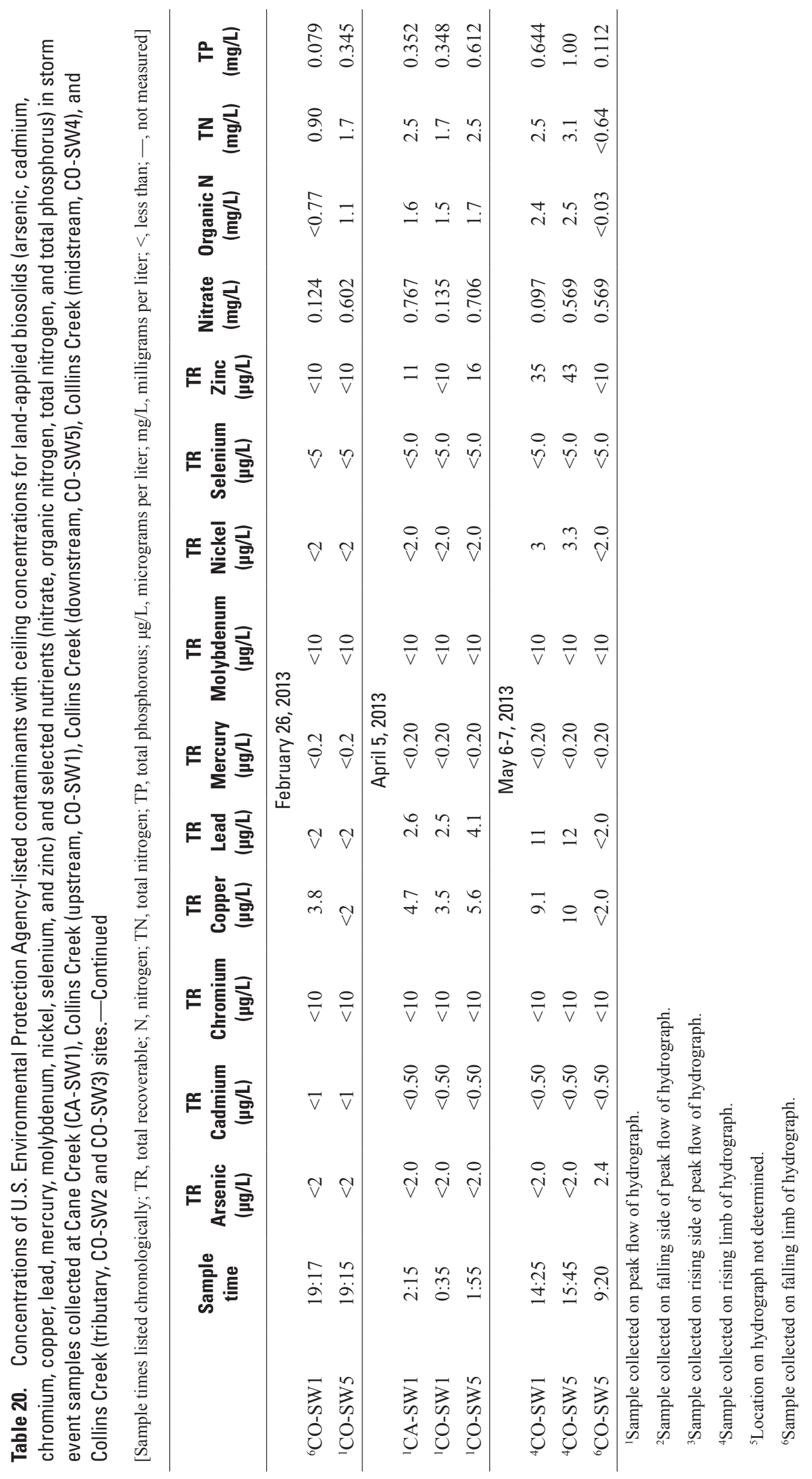




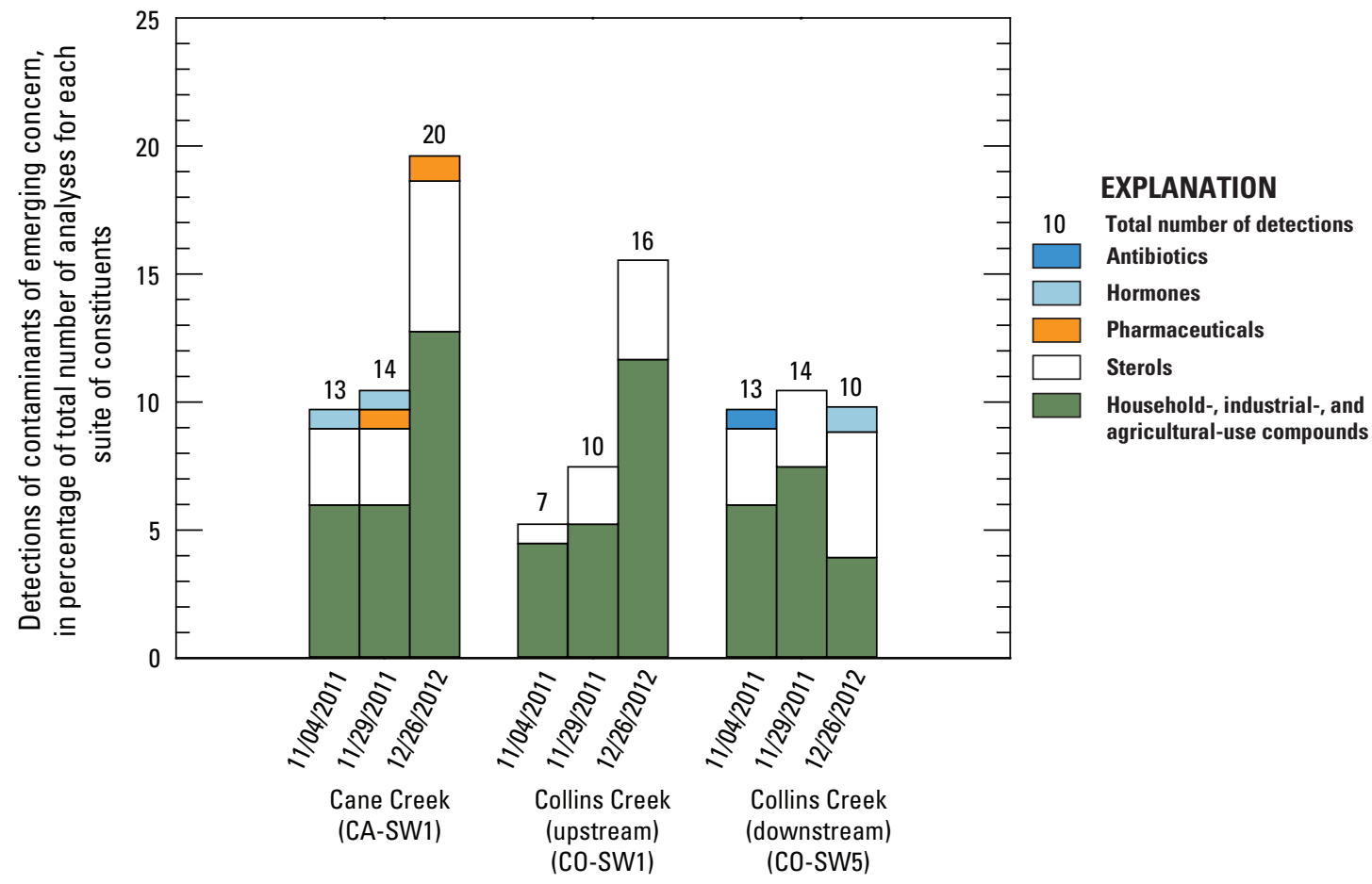

Figure 18. Percentage of detections within the various analytical suites of contaminants of emerging concern in stormwater runoff surface-water samples from Cane Creek and Collins Creek in Orange County, North Carolina. 


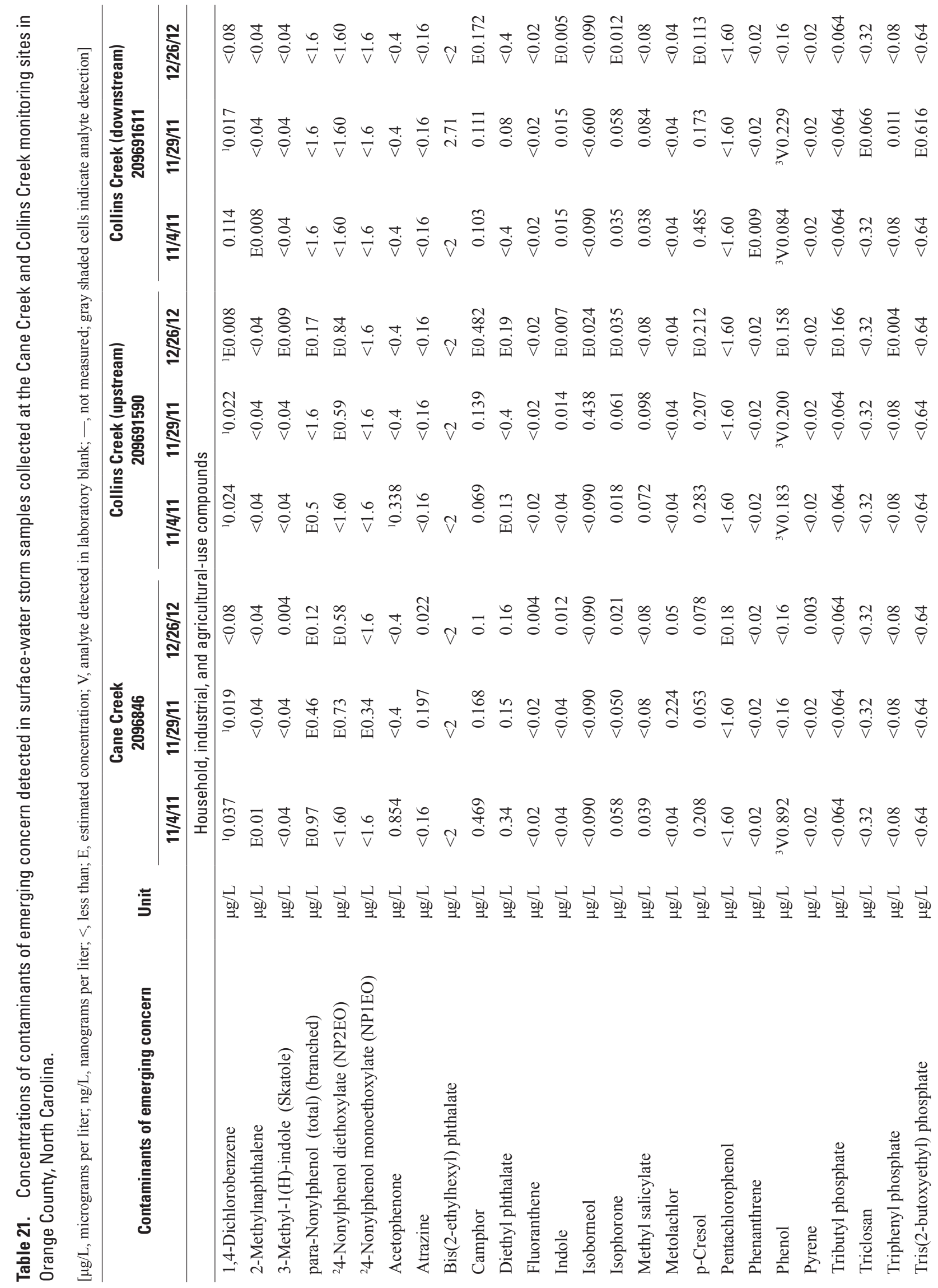




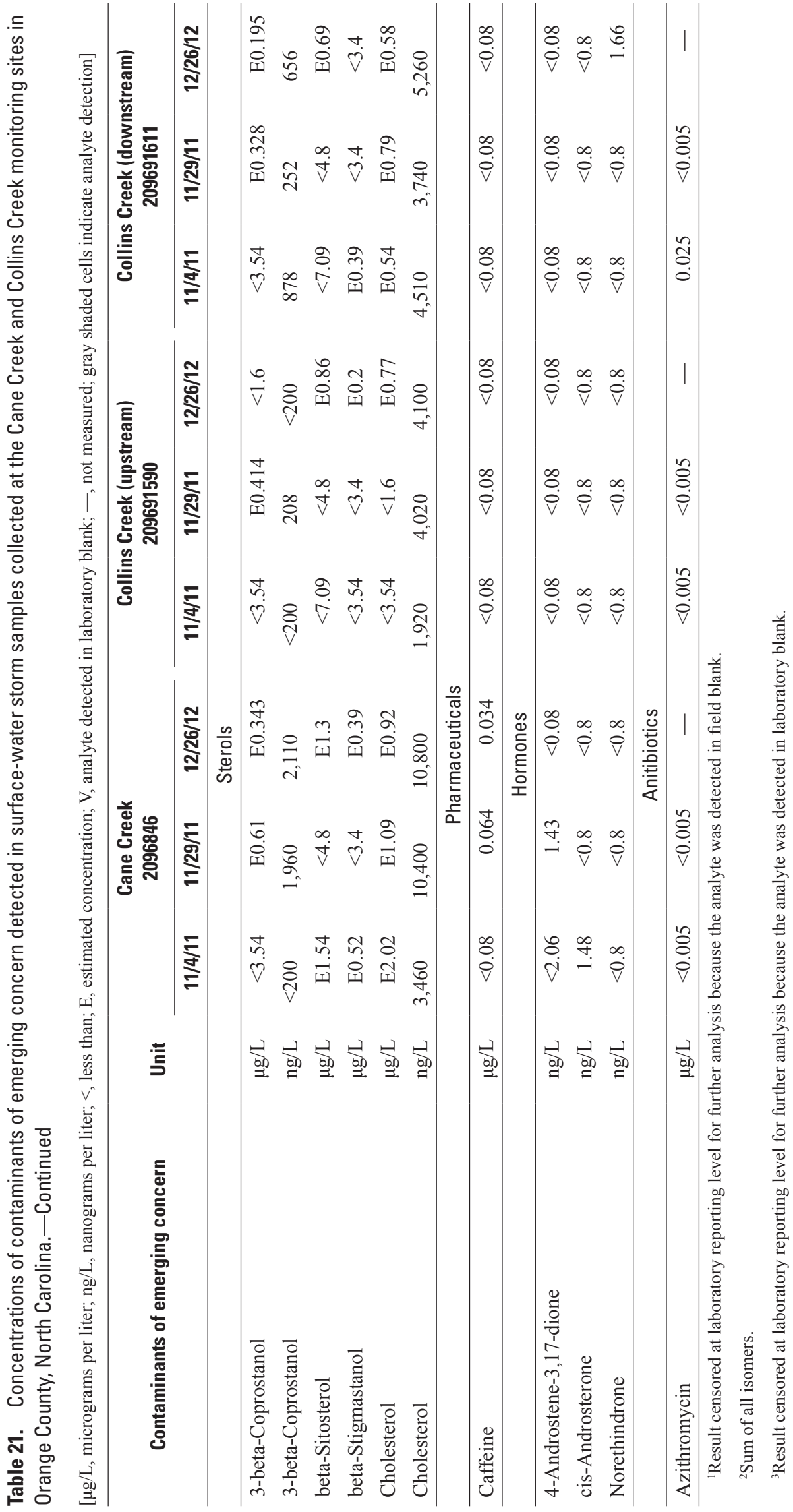


Contaminants of emerging concern were detected more frequently in surface water than in the shallow groundwater. Overall, household-, industrial-, and agricultural-use compounds were detected most frequently in the surface-water samples ( 3 to 13 percent detections) followed by sterols ( 1 to 6 percent detections), and there were few detections of pharmaceuticals, hormones, and antibiotics ( 0 to 2 percent detections) (fig. 18). The analytical variability for contaminants of emerging concern in surface water is unknown, and analytical recovery of about half of the household-, industrial-, and agricultural-use compounds and all the pharmaceuticals in surface-water samples by the laboratory was poor (less than 70 percent or greater than 130 percent) (appendix 3). The background site CA-SW1 had the greatest total contaminants of emerging concern detections (47), followed by CO-SW5 (37) and CO-SW1 (33) (fig. 18), and the detections at all sites were at low levels, which typically were estimated at or just above the reporting levels (tables 5 and 21). The analytical results indicate that the contaminants of emerging concern analyzed as part of this study do not appear to be good indicators of human waste contaminants derived from land-applied biosolids because the number of detections and concentrations at the background sites CA-SW1 and CO-SW1 were similar to or higher than those at the site directly downstream from the land-application fields (CO-SW5) (fig. 18; table 21). Although these results represent a relatively small number of sampling events, the storms occurred very soon after biosolids were land-applied in the fall of 2011 and 2012. In addition, the storms sampled on November 4, 2011, and December 26, 2012, represent the first substantial runoff events that occurred after biosolids were applied to the fields in the fall of those respective years and, therefore, represent ideal conditions in which to observe potentially higher levels of contaminants of emerging concern originating from land-applied biosolids.

\section{Surface-Water Loads and Yields}

Variability in the estimated nutrient loads of nitrate, organic $\mathrm{N}, \mathrm{TN}, \mathrm{TP}$, and E. coli and fecal coliform bacteria for the monitoring sites reflects the variability in both the measured nutrient and bacteria concentrations and streamflows used to compute the loads. Nutrient and bacteria concentrations in streams vary in response to changes in many integrated environmental factors, such as land cover, animal access to streams, potential leaking septic systems, streamflow, and geochemical processes. Streamflow is one of the dominant factors that influences stream nutrient concentrations and loads. The concentrations of some constituents (such as TP) may increase at higher streamflows because of associated increases in particulate matter, whereas other constituents (such as nitrate) may decrease at higher streamflows because of dilution. Although nutrient and bacteria concentrations may vary widely with streamflow, the overall mass of nutrients transported tends to be higher during periods of higher flows because substantially larger volumes of water are being flushed through the watershed (Harden and others, 2013). Streamflow variability among the study sites reflects the size of the watershed drainage area and the amount of precipitation that occurs within the watershed. Examination of the study-period streamflows and drainage areas for the three monitoring sites (table 22) indicates that there is a strong relation between streamflow and drainage area. Similarly, nutrient and bacteria loads are strongly related to drainage areas and to streamflows (table 22). Loads of nutrients and bacteria increase as both drainage areas and streamflows increase. This correlation makes it difficult to examine the effect of land-applied biosolids because variations in the loads are largely controlled by variations in streamflow. Therefore, yields, which normalize the effects of drainage area and streamflow differences among the sites, were used to examine relations between watershed attributes and nutrient transport.

Table 22. Summary of total study period nutrient loads and yields for the Cane Creek and Collins Creek monitoring sites in Orange County, North Carolina.

[Mgal, million gallons; $\mathrm{Mgal} / \mathrm{mi}^{2}$, million gallons per square mile; $1 \mathrm{~b}$, pounds; $1 \mathrm{~b} / \mathrm{mi}^{2}$, pounds per square mile; MPN, most probable number; $\mathrm{N}$, nitrogen; P, phosphorus]

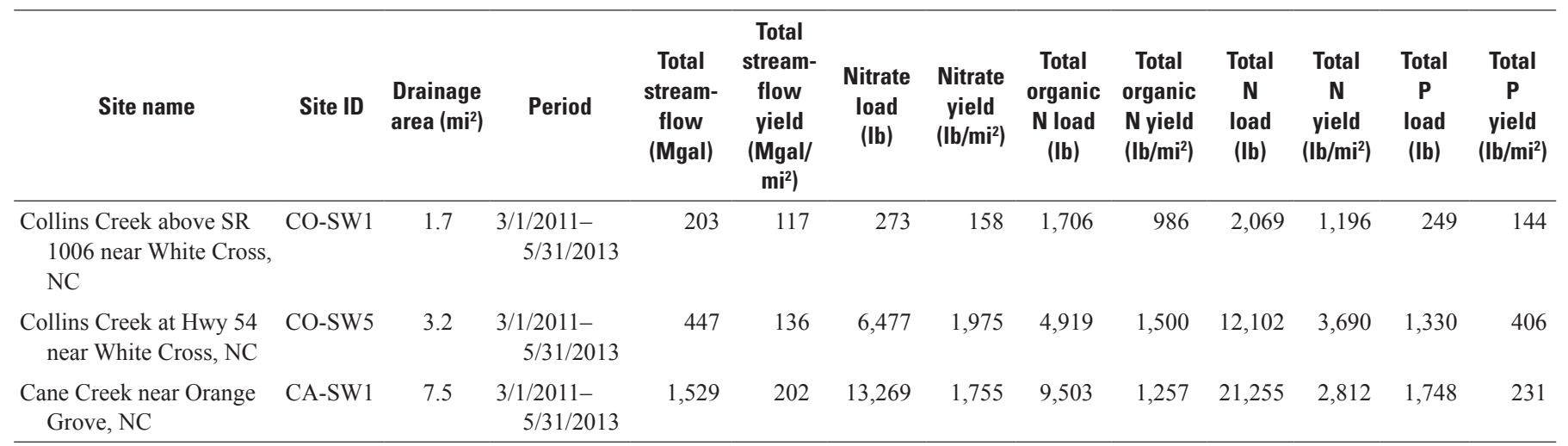


Bacteria loads were computed in the same manner as nutrient loads; however, the standard errors of prediction for the $E$. coli and fecal coliform bacteria loads were large $\left(5.10 \times 10^{5}\right.$ and $3.15 \times 10^{5}$ most probable number (MPN) per day, respectively) as were the upper and lower confidence intervals (appendix tables 4-4-4-6) due to the inherent variability in both the analytical procedures for bacteria and the relation of bacteria concentrations and streamflow. Therefore, the computed monthly, seasonal, and total study period bacteria loads and yields were not used in the analysis; however, instantaneous bacteria loads and yields were computed and are used in the analysis.

Surface-water nutrient loads and yields were computed monthly, seasonally (March-May, June-August, SeptemberNovember, and December-February), and for the complete study period (March 1, 2011-May 31, 2013). The total study period loads and yields presented in table 22 indicate that nutrient yields appear to be slightly elevated at site CO-SW5, which is downstream from the biosolids application fields relative to the other two sites for which their contributing watersheds do not include land application of biosolids. Although apparently higher at site CO-SW5, the nutrient yields at CO-SW5 and CA-SW1 were similar and both were appreciably higher than those at site CO-SW1. The intervening watershed between sites CO-SW1 and CO-SW5 is mostly composed of the biosolids application fields, many of which provide grazing land for beef cattle. Although streamflow yield increased only 16 percent, the nitrate, total organic nitrogen, TN, and TP yields on Collins Creek increased in excess of 1,150 percent, 52 percent, 210 percent, and 180 percent, respectively, from site CO-SW1 to site CO-SW5, illustrating the relatively large amount of nutrients, particularly in the form of nitrate, that the biosolids application fields are contributing to the stream.

Instantaneous bacteria loads and yields were calculated from the bacteria concentrations and instantaneous discharge. The instantaneous bacteria yields are plotted with a time series of daily mean streamflow for the study period to display the variability in bacteria yields relative to streamflow (fig. 19). It is important to note that bacteria concentrations and yields tend to be the highest for storm events that were preceded by an extended low-flow period and (or) dry channel conditions. Given that (1) the chemical analysis of biosolids source material and soil from the agricultural fields show very low or nondetectable bacteria concentrations, (2) cattle graze on agricultural fields in both the Cane Creek and Collins Creek watersheds, and (3) there is visual evidence of cattle physically entering Collins Creek between site CO-SW1 and site CO-SW5, it is likely that the source of the high bacteria concentrations and yields at site $\mathrm{CO}-\mathrm{SW} 5$ is related to cattle and not land-application of biosolids.

Seasonal nutrient loads and yields were computed and analyzed to evaluate the temporal differences in delivery of nutrients to surface water between the monitoring sites (table 23). The nutrient loads and yields were highest for the March-May seasonal period at all three sites followed closely by the December-February period (table 23). These two seasonal periods have the highest streamflow yields (table 23) and the least amount of tree and plant nutrient uptake, which corresponds to higher nutrient delivery to the streams. To further compare the nutrient delivery among the monitoring sites, the relation between nutrient yield and streamflow yield was considered for each site (fig. 20). Figure 20 illustrates that for a given seasonal streamflow yield, site CO-SW5 had a higher seasonal constituent yield for all the nutrients relative to sites CO-SW1 and CA-SW1.

Given the high levels of nitrate concentrations observed for baseflow samples at site CO-SW5 (fig. 16A), an analysis of relative nitrate load contribution to the streams during baseflow and stormwater runoff conditions was conducted for the CO-SW5 and CA-SW1 sites to evaluate if a disproportionate percentage of nitrate load occurred during baseflow at site CO-SW5 relative to site CA-SW1. This analysis focused only on seasonal data for the wetter periods of December-February and March-May in which nitrate concentrations and loads/ yields were the highest (table 23). For the CO-SW5 and CA-SW1 monitoring sites, streamflow hydrograph separations were performed using streamflow data to determine the BFI, or percentage contribution of the annual streamflow derived from baseflow, or groundwater discharge. For example, a computed BFI of 0.256 indicates that the mean annual contribution of groundwater to the total streamflow during the period of analysis was 25.6 percent with the balance (74.4 percent) derived from stormwater runoff. Hydrograph separations were performed using the Web-based hydrograph analysis tool (WHAT; Lim and others, 2005) that uses the local minimum and digital filtering methods to separate baseflow data from daily streamflow data. For consistency, the local minimum method was used to determine the average BFI for the study period at the CO-SW5 and CA-SW1 monitoring sites. The computed BFIs for the study period are 0.262 for CO-SW5 and 0.340 for CA-SW1. Daily mean streamflow was subdivided into three categories: days with mean streamflow composed of (1) greater than 75 percent baseflow, (2) greater than 25 percent and less than 75 percent baseflow, and (3) less than 25 percent baseflow (which can be considered mostly stormwater runoff).

The percentage of total seasonal nitrate loads for each of the categories of baseflow percentage is summarized in table 24. Despite the significantly different nitrate concentrations for baseflow samples collected at sites CO-SW5 and CA-SW1, the percentage of total seasonal nitrate load on days when baseflow is at least 75 percent of the daily streamflow is similar between the two sites. The mean percentage of total seasonal nitrate load for days with streamflow composed of at least 75 percent baseflow at sites CO-SW5 and CA-SW1 is 22.9 percent and 20.9 percent, respectively. Therefore, despite the significantly higher nitrate concentrations measured during baseflow at site CO-SW5 than at site CA-SW1, there is little difference between the total nitrate load being delivered during baseflow at the two sites. 


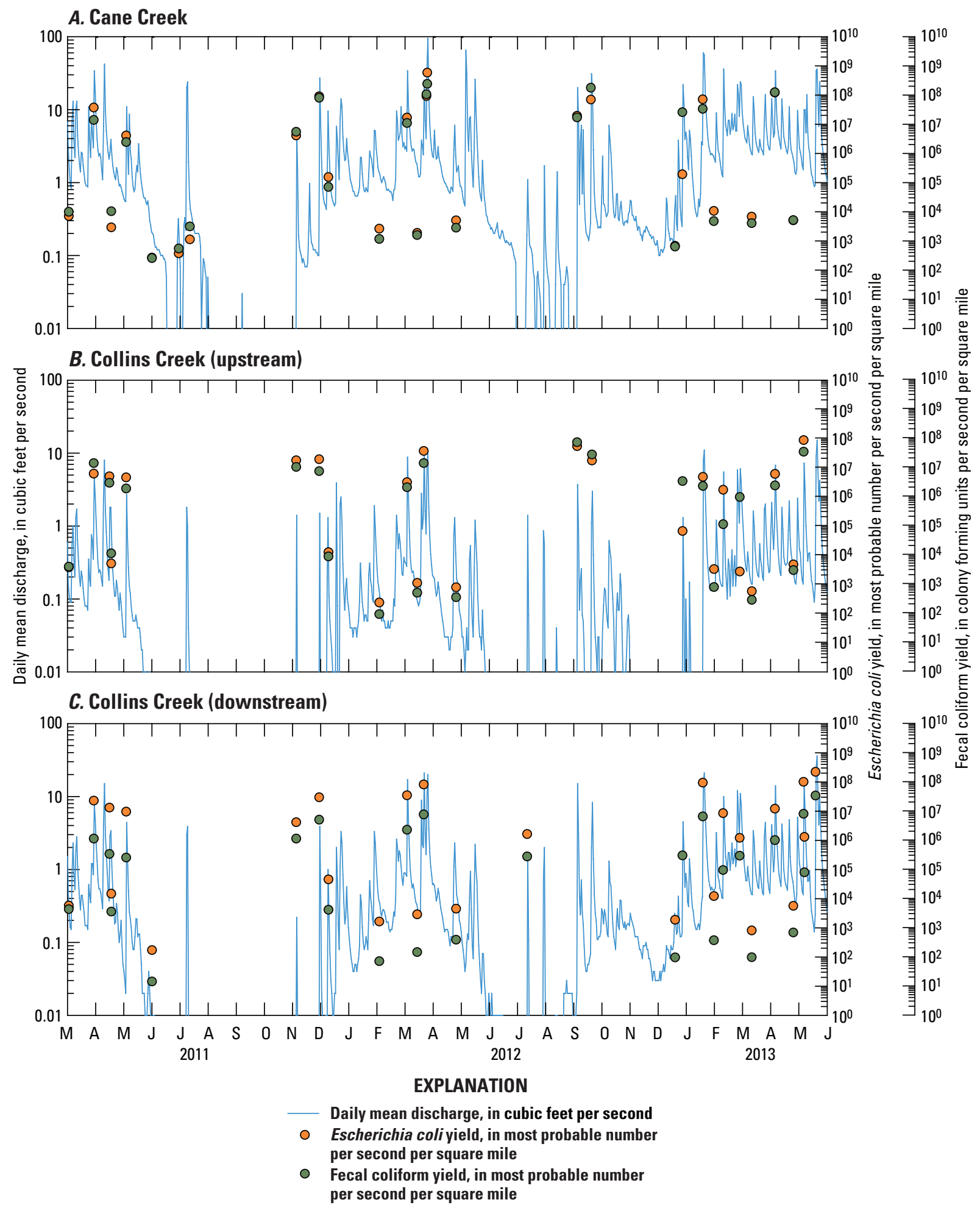

Figure 19. Daily mean discharge, Escherichia coli yield, and fecal coliform yield for streamgages and water-quality monitoring sites: ( $A$ ) Cane Creek (02096846, site ID CA-SW1), $(B)$ Collins Creek (upstream) (site ID 0209691590, site ID CO-SW1), and (C) Collins Creek (downstream) (0209691611, site ID CO-SW5), in Orange County, North Carolina. 


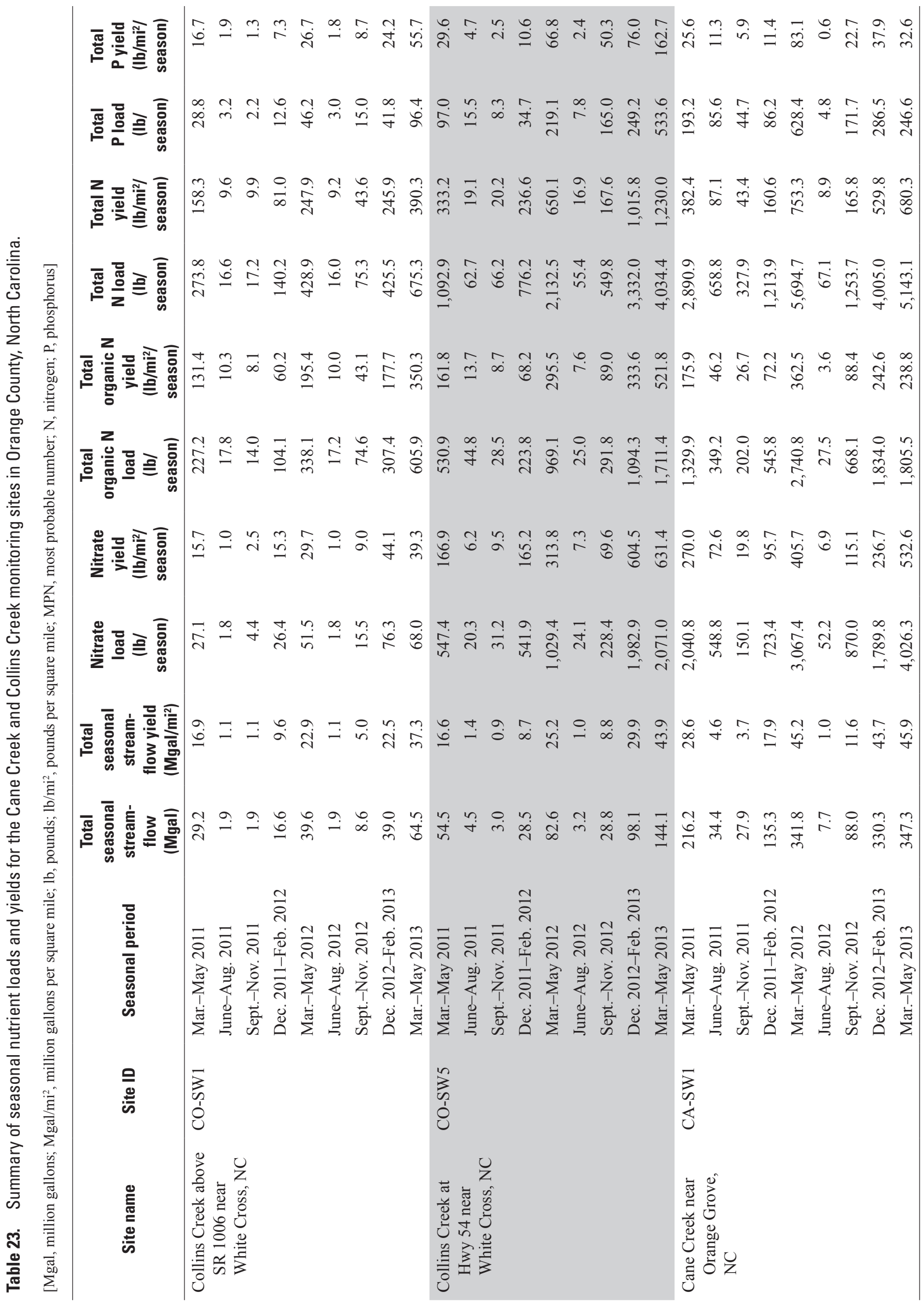



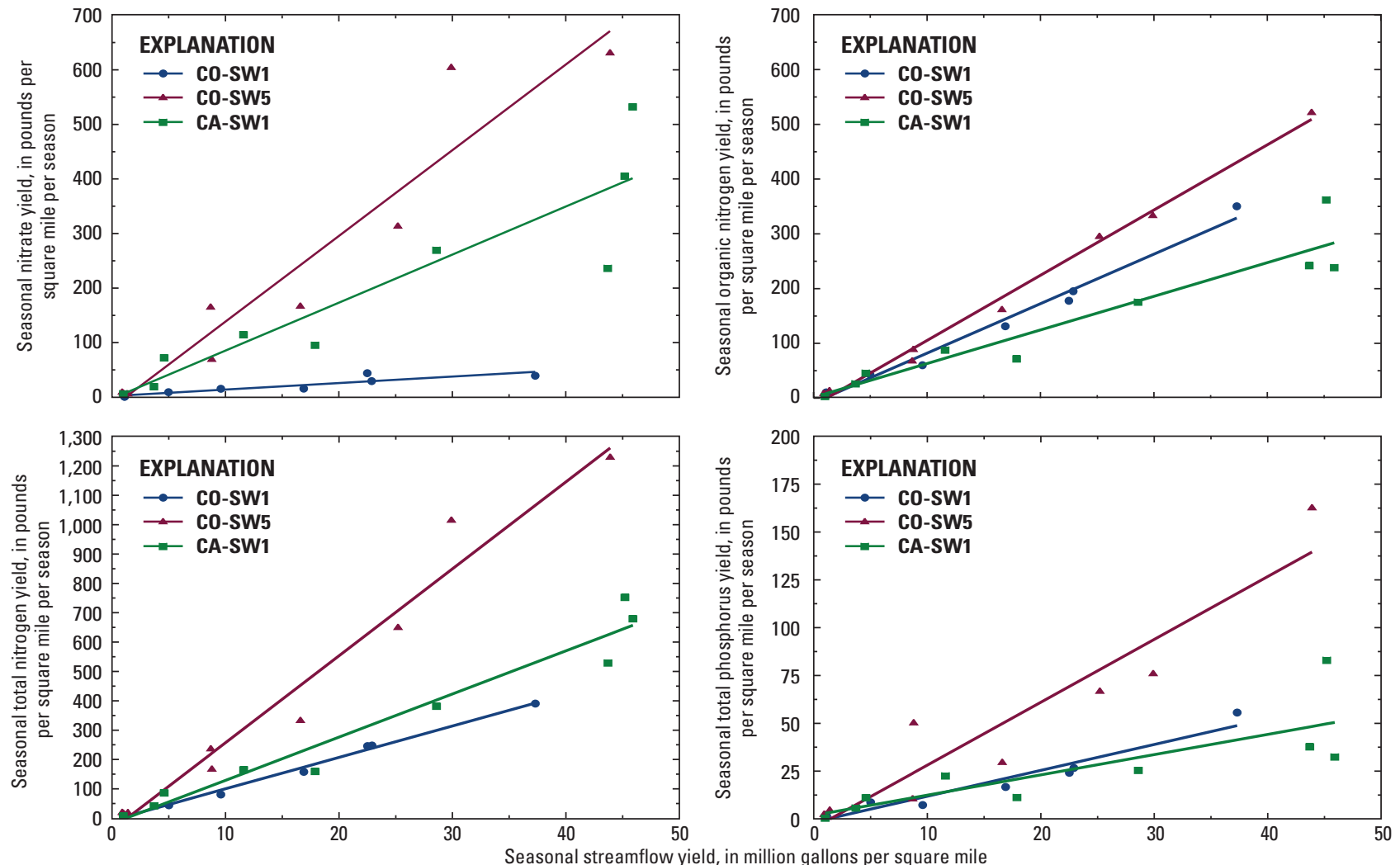

Figure 20. Relation of seasonal nutrient and streamflow yields for the Cane Creek (02096846, site ID CA-SW1), Collins Creek (upstream) (0209691590, site ID CO-SW1), and Collins Creek (downstream) (0209691611, site ID CO-SW5) water-quality monitoring sites in Orange County, North Carolina.

Table 24. Summary of fractions of seasonal nutrient loads during days when the streamflow is composed of (1) greater than or equal to 75 percent baseflow, (2) greater than 25 percent and less than 75 percent baseflow, and (3) less than or equal to 25 percent baseflow for the Cane Creek and Collins Creek monitoring sites in Orange County, North Carolina.

[ $\geq$, greater than or equal to; $>$, greater than; $<$, less than; $\leq$, less than or equal to; $\%$, percent]

\begin{tabular}{|c|c|c|c|c|c|c|c|}
\hline \multirow[b]{2}{*}{ Site ID' } & \multirow[b]{2}{*}{ Season } & \multicolumn{6}{|c|}{ Total daily nitrate load in pounds } \\
\hline & & $\begin{array}{c}\geq 75 \% \text { daily } \\
\text { baseflow }\end{array}$ & $\begin{array}{c}\text { Percentage of } \\
\text { total seasonal } \\
\text { load }\end{array}$ & $\begin{array}{c}>25 \text { to }<75 \% \\
\text { daily baseflow }\end{array}$ & $\begin{array}{c}\text { Percentage of } \\
\text { total seasonal } \\
\text { load }\end{array}$ & $\begin{array}{c}\leq \mathbf{2 5} \% \text { daily } \\
\text { baseflow }\end{array}$ & $\begin{array}{c}\text { Percentage of } \\
\text { total seasonal } \\
\text { load }\end{array}$ \\
\hline CO-SW5 & Mar.-May 2011 & 80.4 & 14.7 & 162.2 & 29.6 & 304.9 & 55.7 \\
\hline CA-SW1 & & 353.7 & 17.3 & 517.0 & 25.3 & $1,170.2$ & 57.3 \\
\hline CO-SW5 & Dec. 2011-Feb. 2012 & 159.5 & 29.4 & 176.4 & 32.6 & 206.0 & 38.0 \\
\hline CA-SW1 & & 198.6 & 27.4 & 282.7 & 39.1 & 242.1 & 33.5 \\
\hline CO-SW5 & Mar.-May 2012 & 257.3 & 25.0 & 145.1 & 14.1 & 627.0 & 60.9 \\
\hline CA-SW1 & & 417.7 & 13.6 & 559.1 & 18.2 & $2,090.6$ & 68.2 \\
\hline CO-SW5 & Dec. 2012-Feb. 2013 & 413.5 & 20.9 & 619.3 & 31.2 & 950.1 & 47.9 \\
\hline CA-SW1 & & 316.0 & 17.7 & 793.4 & 44.3 & 680.4 & 38.0 \\
\hline CO-SW5 & Mar.-May 2013 & 511.6 & 24.7 & 567.0 & 27.4 & 992.5 & 47.9 \\
\hline CA-SW1 & & $1,002.2$ & 24.9 & $1,426.3$ & 35.4 & $1,597.8$ & 39.7 \\
\hline
\end{tabular}

\footnotetext{
${ }^{1}$ See table 2 for complete site names and information.
} 


\section{Benthic-Macroinvertebrate Surveys}

Benthic-macroinvertebrate sampling was conducted by NCDENR on May 17, 2012, at the three monitoring sites, following established protocols specified in NCDENR, Division of Water Resources (2013) to assess any differences in stream ecologic health that could be attributed to landapplied biosolids. The Division of Water Quality's Qual-4 (North Carolina Department of Environment and Natural Resources, 2009) and Standard Qualitative (Full Scale) sampling methods were used (North Carolina Department of Environment and Natural Resources, Division of Water Resources, 2013). The Qual-4 sampling method is used in small streams with drainage areas less than or equal to 3 square miles $\left(\mathrm{mi}^{2}\right)$ and consists of one sweep, one kick, one leaf pack, and visuals. Habitats such as riffles, macrophytes, root mats/undercut banks, and detritus deposits were sampled using these techniques. Full-scale samples were conducted in wadeable streams with drainage areas greater than $3 \mathrm{mi}^{2}$ (North Carolina Department of Environment and Natural Resources, Division of Water Resources, 2013). This sampling method consists of collecting 10 separate samples including three sweep-net samples; two kick-net samples, one leaf pack, two fine-mesh log and (or) rock wash samples, one sand sample, and visuals of substrates not otherwise easily sampled using previous techniques. Habitats such as riffles, macrophytes, root mats/undercut banks, and detritus deposits were sampled using these techniques.

The benthic samples collected at the Collins Creek sites (CO-SW1 and CO-SW5) did not indicate any differences between the two locations. Both sites received "Poor" bioclassifications (table 25), suggesting that Collins Creek may suffer from organic and inorganic pollution from sources upstream from the biosolids application fields (such as dairy and beef cattle farms and corn and soybean crops). The classification may be exacerbated by low-flow conditions and dry channels in the summer as well as fluctuations in dissolved oxygen and decreased habitat availability for benthic fauna. Drought conditions in the summer of 2011 likely further stressed the ecology in the Collins Creek watershed (Victor Holland, North Carolina Department of Environment and Natural Resources, written commun., 2013).

Another factor that could have reduced the North Carolina Biotic Index (NCBI) values at the upstream Collins Creek site (CO-SW1) is limited macroinvertebrate habitat. The upstream Collins Creek site (CO-SW1) received a habitat score of 63 and the downstream Collins Creek site (CO-SW5) received a score of 77 (table 26). Compared to the downstream site, the upstream site lacked riffles and other favorable in-stream habitats such as leaf packs, sticks, and root mats. Severe erosion was noted above Secondary Road 1006, and the stream likely receives flashy flows that can lead to bank sloughing, colluvial deposits, and further siltation of the stream following rain events. Benthic macroinvertebrate habitat scores from Cane Creek (CA-SW1) indicated better habitats including longer riffles, bank stability, and less erosion compared to that observed in the Collins Creek watershed.

The Cane Creek site (CA-SW1) received "Good" bioclassifications from 1986 to 1998 and was rated "Excellent" on one occasion in 1998 (North Carolina Department of Environment and Natural Resources, 1999). The site has received "Good-Fair" bioclassifications since 2003, and the Ephemeroptera, Plecoptera, and Trichoptera (EPT) taxa richness has declined since a 2009 basinwide benthic sample was collected (NCDENR, 2009). The Cane Creek (CA-SW1) site received a "Good-Fair" bioclassification in 2012 as part of the current study (table 25) (Victor Holland, North Carolina Department of Environment and Natural Resources, written commun., 2013). The differences between the bioclassifications in the Cane Creek and Collins Creek watersheds are likely related to flow conditions in the streams. Collins Creek went completely dry during the study period, while Cane Creek always had pooled water in the channel despite having some periods of zero flow during the drought conditions in 2011. 
Table 25. Benthic community metrics at the Collins Creek and Cane Creek study sites in Orange County, North Carolina, sampled May 17, 2012.

[SR, Secondary Road; HWY, highway; $\mathrm{mi}^{2}$, square miles; EPT, Ephemeroptera, Plecoptera, and Trichoptera; NCBI, North Carolina biotic index)

\begin{tabular}{|c|c|c|c|}
\hline Stream & Collins Creek & Collins Creek & Cane Creek \\
\hline Site Location & Above SR 1006 & HWY 54 & SR 1114 \\
\hline Site ID & CO-SW1 & CO-SW5 & CA-SW1 \\
\hline County & Orange & Orange & Orange \\
\hline Collection date & $5 / 17 / 2012$ & $5 / 17 / 2012$ & $5 / 17 / 2012$ \\
\hline Sample method & Qual 4 & Qual 4 & Full Scale \\
\hline Criteria & Spring/Piedmont & Spring/Piedmont & Spring/Piedmont \\
\hline Drainage area $\left(\mathrm{mi}^{2}\right)$ & 1.7 & 3.3 & 7.6 \\
\hline \multicolumn{4}{|c|}{ Richness } \\
\hline Ephemeroptera & 0 & 1 & 6 \\
\hline Plecoptera & 1 & 1 & 1 \\
\hline Trichoptera & 2 & 2 & 2 \\
\hline Total EPT & 3 & 4 & 9 \\
\hline Odonata & 2 & 2 & 2 \\
\hline Megaloptera & 0 & 0 & 3 \\
\hline Coleoptera & 4 & 6 & 7 \\
\hline Chironomidae & 7 & 9 & 13 \\
\hline non-Chironomidae Diptera & 3 & 5 & 5 \\
\hline Oligochaeta & 2 & 1 & 1 \\
\hline Mollusca & 3 & 3 & 6 \\
\hline Other taxa & 4 & 4 & 4 \\
\hline Total taxa richness & 28 & 34 & 50 \\
\hline \multicolumn{4}{|c|}{ Other biological metrics } \\
\hline EPT abundance & 7 & 13 & 42 \\
\hline EPT Biotic Index & 6.24 & 3.55 & 3.97 \\
\hline NCBI & 7.2 & 6.47 & 5.51 \\
\hline Seasonal Correction & & & 0.2 \\
\hline Corrected NCBI & & & 5.71 \\
\hline Bioclassification & Poor & Poor-EPT & Good-Fair \\
\hline
\end{tabular}


Table 26. Habitat and physiochemical properties measured at the Collins Creek and Cane Creek study sites in Orange County, North Carolina, May 17, 2012.

[SR, Secondary Road; HWY, highway; \%, percent; ${ }^{\circ} \mathrm{C}$, degrees Celisus; mg/L, milligrams per liter; $\mu \mathrm{S} / \mathrm{cm}$, microsiemens per centimeter)

\begin{tabular}{|c|c|c|c|}
\hline Stream & Collins Creek & Collins Creek & Cane Creek \\
\hline Site Location & Above SR 1006 & Hwy 54 & SR 1114 \\
\hline Site ID & CO-SW1 & CO-SW5 & CA-SW1 \\
\hline County & Orange & Orange & Orange \\
\hline Collection date & $5 / 17 / 2012$ & $5 / 17 / 2012$ & $5 / 17 / 2012$ \\
\hline \multicolumn{4}{|c|}{ Habitat scores } \\
\hline Channel modification (5) & 5 & 5 & 5 \\
\hline In-stream habitat (20) & 8 & 16 & 16 \\
\hline Bottom substrate (15) & 12 & 11 & 8 \\
\hline Pool variety (10) & 8 & 8 & 8 \\
\hline Riffle habitats (16) & 7 & 10 & 12 \\
\hline Bank stability/vegetation (14) & 5 & 7 & 11 \\
\hline Light penetration (10) & 10 & 10 & 10 \\
\hline Riparian zone width (10) & 8 & 10 & 10 \\
\hline Total Habitat (100) & 63 & 77 & 80 \\
\hline \multicolumn{4}{|c|}{ Other habitat } \\
\hline Canopy (\%) & 70 & 60 & 60 \\
\hline \multicolumn{4}{|l|}{ Substrate (\%) } \\
\hline Boulder & 0 & 10 & 40 \\
\hline Cobble & 10 & 25 & 30 \\
\hline Gravel & 20 & 20 & 10 \\
\hline Sand & 50 & 25 & 10 \\
\hline Silt & 20 & 15 & 10 \\
\hline Bedrock & 0 & 15 & 0 \\
\hline \multicolumn{4}{|c|}{ Physiochemical properties } \\
\hline Temperature $\left({ }^{\circ} \mathrm{C}\right)$ & 18.7 & 18.4 & 19.8 \\
\hline Dissolved oxygen $(\mathrm{mg} / \mathrm{L})$ & 7.2 & 7.7 & 7.9 \\
\hline Specific conductance $(\mu \mathrm{S} / \mathrm{cm})$ & 59 & 79 & 79 \\
\hline $\mathrm{pH}$ & 6 & 6.2 & 6.8 \\
\hline
\end{tabular}




\section{Genetic Biomarkers}

As discussed previously, the biosolids treatment process removed all organisms that would allow the bacteria biomarkers analyzed in this study to be detected in biosolids samples. However, in order to evaluate if the predominant source of bacteria (other than biosolids) in surface-water samples could be traced back to cattle, the CF128 biomarker, which was detected in fecal samples from the cattle grazing on the biosolids land-application fields, was analyzed in selected stormwater runoff samples with the highest bacteria concentrations. Real-time qPCR of salmon testes gDNA indicated an average 9.04 percent of gDNA from the MoBio Powersoil procedure for water samples. Positive control samples produced a strong band at the expected band size of 580 base pairs (bp), and no template control samples returned amplified products. Analysis of gel electrophoresis images of the amplified products from the seven selected stormwater runoff samples from Collins Creek and Cane Creek with the highest bacteria concentrations indicate that three of the samples (all of which were collected from the CO-SW5 site on Collins Creek) were associated with positive returns for the CF128 biomarker. Samples from Cane Creek (site CA-SW1) with elevated bacteria concentrations similar to those in Collins Creek downstream from the biosolids application fields (site CO-SW5) did not show positive returns for the CF128 biomarker. This finding indicates that for the surface-water samples with the highest bacteria concentrations, the cattle grazing in and around the main stem and tributaries to Collins Creek on the OWASA biosolids land-application fields are likely the predominant source of elevated bacteria in Collins Creek downstream from the biosolids application fields. Although the CF128 biomarker was not detected in Cane Creek samples, the results do not preclude cattle from being the predominant source of elevated bacteria concentrations in Cane Creek. Cattle could still be the major contributor of bacteria in Cane Creek if the sources were located further from the sampling point, which would allow for degradation of the biomarkers below the detection limits of the analyses.

\section{Summary and Conclusions}

A paired agricultural watershed study was conducted in the Collins Creek and Cane Creek watersheds in Orange County, North Carolina, to better understand the transport of nutrients and bacteria from biosolids application fields to groundwater and surface water and to provide a scientific basis for evaluating the effectiveness of the current biosolids land-application regulations. The study was conducted by the USGS in cooperation with NCDENR through the 319 Nonpoint Source Program. Field activities were conducted March 2011 through June 2013 at two field study sites, including biosolids field application sites owned by OWASA on Collins Creek and a background study site on Cane Creek that has no fields receiving biosolids applications. At the Collins Creek biosolids field application sites, samples of biosolids source material and soil were collected from the land-application fields for laboratory analyses. Soil samples were also collected from the background agricultural field in the Cane Creek watershed, which has never received land-applied biosolids. Quarterly shallow groundwater samples were collected from monitoring wells installed for this study by NCDENR along the edge of biosolids land-application fields and the background agricultural field for laboratory analyses. Two surfacewater monitoring sites were established on Collins Creek to compute continuous streamflow and collect discrete baseflow and stormwater runoff water-quality data upstream and downstream from the biosolids land-application fields. Surface water-quality samples were also collected for baseflow and stormwater runoff conditions at an existing USGS streamgage on Cane Creek to monitor water-quality conditions in the background study watershed. The study primarily focused on nutrients and bacteria - priority constituents for the 319 Nonpoint Source Program - and the study area is included in a nutrient total maximum daily load requirement. However, data for field properties and water-quality constituents, including metals, major ions, and contaminants of emerging concern (household-, industrial-, and agricultural-use compounds, pharmaceutical compounds, hormones, and antibiotics) also were collected and used in the analyses.

Biosolids treatment processes and storage techniques used by OWASA are effective in eliminating $E$. coli and fecal coliform bacteria. Bacteria concentrations in land-applied biosolids samples were below analytical detection limits, and there were no differences between bacteria concentrations in soil from the biosolids land-application and background fields. There were no exceedances of the 10 elements with designated EPA ceiling concentrations in any of the biosolids and soil samples. The concentrations through three applications of biosolids stayed fairly uniform over time within and between fields. The exceptions were concentrations of the two bacteria groups that fluctuated somewhat in all fields, including the background field, and did not seem to be related to biosolids application. The hypothesis may be that repeated application over a much longer time frame might eventually result in measurable accumulation of metals and nutrients in soil. Given that biosolids have been applied to fields AF 11-2, AF 11-4, and AF 11-6 for more than 25 years, this hypothesis was evaluated by comparing median concentrations of the 10 constituents with EPA-designated ceiling concentrations as well as TKN, TP, and bacteria in each application field to the background field. Compared to the background field, the biosolids land-application fields had elevated concentrations of copper, mercury, molybdenum, TKN, and TP. The background field had the highest median concentrations of cadmium, lead, selenium, and fecal coliform. Finally, the median concentrations of five constituents (arsenic, chromium, nickel, zinc, and E. coli.) overlapped between the application fields and the background field. 
The potential short-term effect of land application of biosolids to agricultural fields was evaluated using both the chemical concentration and dry mass of the biosolids samples in relation to that of the (pre-application) soil onto which it was applied. The median concentration ratio of the 10 elements with EPA-designated ceiling concentrations in biosolids compared to the soils ranged from 2 for lead to approximately 37 for molybdenum. The biosolids to pre-application soils concentration ratios for TKN and TP were 46 and 24, respectively. The median dry mass ratio in soil to biosolids samples was 2,300 (range of $\sim 500$ to $\sim 6,400$ ). So despite the larger elemental concentration in biosolids compared to soil, the mass of biosolids "mixed" into the upper 6 inches of soil in the homogenized core material would likely be too small to consistently be detected between pre- and post-application soil samples. Given the fact that biosolids have been applied to the fields for more than 25 years and the relatively small amount of dry mass of biosolids applied to the fields during each application, it is not surprising that there is not a detectable difference between pre- and post-application soil samples.

Selected biosolids and soil samples were collected and analyzed for contaminants of emerging concern (household-, industrial-, and agricultural-use compounds, sterols, pharmaceuticals, hormones, and antibiotics) from biosolids land-application fields AF11-2, AF 11-4 and AF 11-6 and the background field. The highest frequency of detections in all media was for the suite of household-, industrial-, and agricultural-use compounds, and these compounds accounted for most of the detections in each media. Hormones were detected in all media though were relatively more abundant in the pre- and post-application soils and biosolids compared to the background soil. Pharmaceuticals were largely detected only in the application fields and biosolids. Similar detection frequencies of sterols in biosolids land-application and background soils and biosolids were consistent with natural sources. Finally, only the pre-application soil had detections of the few antibiotics that were included in the pharmaceutical suite.

Twelve emerging contaminant compounds were detected in the background field soil sample, which is far less than the number of compounds detected in the biosolids land-application soil samples. Eleven of the twelve compounds (carbazole, fluoranthene, $p$-cresol, phananthrene, pyrene, 3-methyl-1(H)indole [skatol], indole, beta-sitosterol, beta-stigmastanol, cholesterol, and 4-androstene-3,17-dione) were also frequently detected in the biosolids and biosolids-application soil samples. Therefore, biosolids cannot be the only source of these 11 compounds given that they were detected in the background soil samples collected from the background field, which never received application of biosolids.

There is a general increase in the number of detections in the biosolids land-application fields soil samples corresponding to the increases in the number of detections in the biosolids samples, although it is not very pronounced. Compounds that were often detected in both the biosolids-application soils and the biosolids samples but not in the background field include 2,6-dimethylnaphthalene, benzo $[a]$ pyrene, acetylhexamethyl tetrahydronaphthalene (AHTN), 2,2',4,4'-tetrabromodiphenylether (PBDE 47), d-limonene, and triclosan. For these compounds, biosolids are likely the dominant source to the biosolids-application soils. Compounds that were frequently detected in the biosolids-application soils but rarely or never in biosolids include anthraquinone, triphenyl phosphate, and 1,4-dichlorobenzene. These compounds likely do not have a source from the biosolids. Compounds found frequently in biosolids but infrequently or never in biosolids-application soils include camphor, anthracene, and DEET (N,Ndiethyl-meta-toluamide) among the household-, industrial-, and agricultural-use compounds, citalopram and sertraline among the pharmaceuticals, and 17-alpha-estradiol among the hormones. This infrequency of detections in biosolidsapplication field soil samples might be due to post-application degradation or the dilution effect of the relatively small mass of land-applied biosolids to that of the soils.

Various hydrocarbons were analyzed in selected biosolids and soil samples. These compounds included BTEX (benzene, toluene, ethylbenzene, and xylenes), gasoline-range organics (C6-C10), motor oil range organics (C24-C36), total extractable hydrocarbons (C10-C36), HEM ( $n$-hexane extractable materials), SGT-HEM (silica gel treated $n$-hexane extractable material), and the fuel oxygenate MTBE (methyl-tert-butyl ether). Although most of these compounds were detected in the biosolids samples, only HEM, motor oil range organics, and total extractable hydrocarbons were detected frequently in soils and in roughly similar concentrations between the two media. If biosolids were the main source of BTEX and gasoline range organics, these compounds appeared to be lost rapidly (days), likely due to volatilization.

Given that there were cattle grazing on the biosolids land-application fields, the USGS conducted an evaluation to determine if there were specific bacteria biomarkers that could distinguish the source of bacteria in soil and surface-water samples as being primarily from municipal human biosolids or cattle. There were no detections of the quantitative human biomarkers Hum and CowM1 and CowM2 in biosolids source samples nor were there detections of the human fecal marker HF183 in biosolids samples. There also was no detection of CowM1 and CowM2 biomarkers in the cattle manure samples. The CF128 biomarker, however, was detected in a cattle manure sample and, therefore, was analyzed in surface-water samples. Detection of GenBac3 markers in biosolids samples indicated that nondetection of CF128 or HF183 was not due to lack of Bacteroidales $16 \mathrm{~S}$ rDNA in the samples. Therefore, the biosolids treatment process was shown to effectively kill the organisms from which the genetic biomarkers used in this study were designed, and further research to find a biomarker that could be used to trace municipal human biosolids is warranted.

The first step used to characterizing the effect agricultural watersheds with and without land-applied biosolids had on constituent concentrations in the underlying shallow groundwater was statistical comparison testing to evaluate if there 
were statistically significant differences (at the 95 percent confidence interval) in groundwater concentrations of nutrients and selected ions between winter/spring and summer/fall seasons and among the six shallow groundwater monitoring wells. There was no statistical difference between the winter/ spring and summer/fall seasonal groupings for nitrate, $\mathrm{TN}$, TP, chloride, calcium, potassium, or sodium at the six monitoring wells. The nitrate concentrations in well OR-686, which is located adjacent to biosolids application fields but upgradient from areas of application and downgradient from a large tract of forest that is not owned by OWASA, were statistically different and lower than nitrate concentrations in all the other study wells. Wells OR-687 and OR-688 are located adjacent to and topographically downgradient from the biosolids application fields and were found to be statistically different and have higher nitrate concentrations than all the other wells. The nitrate concentrations measured in the wells adjacent to the background agricultural field, wells OR-689 and OR-690, are statistically different from each other and from wells OR-686, OR-687, and OR-688 but no different than well OR-685. Median nitrate concentrations of samples collected from wells OR-687 and OR-688 (12.4 mg/L and $10.7 \mathrm{mg} / \mathrm{L}$, respectively) were above the EPA drinking-water standard of $10 \mathrm{mg} / \mathrm{L}$. Comparisons among the wells for TN concentrations mimic the results for nitrate because nitrate was the dominant species of nitrogen in the wells. Overall, TP concentrations in the wells were relatively low, but there were statistical differences among the wells adjacent to the biosolids fields (except between wells OR-687 and 686) and between the wells in the background agricultural field and those adjacent to the biosolids application fields (except from well OR-688). The results of the statistical comparison tests for the selected ions did not indicate any trend among the wells, and overall there was significant variability among the selected ion concentrations measured in the wells during the study, which likely is attributed to the local variability in geochemistry of soils and geology.

To further evaluate any differences in the shallow groundwater quality under agricultural fields with and without land-applied biosolids and the contribution to surface water, the concentrations of EPA-listed contaminants with ceiling concentrations for land-applied biosolids and nutrients were analyzed. Except for dissolved nickel concentrations in wells OR-685 and OR-688, the median concentrations of all the constituents with EPA ceiling concentrations were less than the long-term detection level that was established by the NCDENR water-quality laboratory that conducted the analysis of these constituents.

Shallow groundwater samples were collected in December of 2011 and analyzed for contaminants of emerging concern (household-, industrial-, and agricultural-use compounds, sterols, pharmaceuticals, hormones, and antibiotics) from five of the six monitoring wells. Household-, industrial-, and agricultural-use compounds were the only constituents detected in the groundwater samples. Well OR-686 had the most total detections (14) followed by well OR-685 (7), and the detections at all wells were at low levels - typically at or just above the reporting levels. Although topographically upgradient from the biosolids land-application fields, well OR-686 is located directly adjacent to two private residences that are on septic systems, which may explain the elevated number of emerging contaminant detections relative to the other wells. These analytical results indicate that the contaminants of emerging concern analyzed as part of this study do not appear to be good groundwater indicators of human waste contaminants derived from land-applied biosolids because the number of detections and concentrations at the background well OR-690 are similar to those wells downgradient and adjacent to the biosolids land-application fields (wells OR-687 and OR-688).

Similar to the analysis of the groundwater data, statistical comparison testing was conducted to evaluate if there were statistically significant differences (at the 95 percent confidence level) in surface-water concentrations of nutrients, bacteria, and selected ions between baseflow and stormwater runoff conditions at each monitoring site, between winter/ spring and summer/fall seasonal groupings, and among the three monitoring sites. Statistical analyses for the metals with EPA ceiling concentrations for land-applied biosolids were not performed because these compounds either were detected in less than eight baseflow and (or) storm samples at a site or all of the concentrations were estimated to be less than the long-term method detection level.

With the exception of nitrate and total nitrogen concentrations at the Collins Creek site downstream from the biosolids application fields (CO-SW5), nutrient concentrations generally were higher in storm samples than in baseflow samples. In contrast to the background sites (CA-SW1 and CO-SW1), the maximum, range, and median baseflow nitrate concentrations were all appreciably higher and statistically different than the storm sample concentrations at the CO-SW5 site. This difference indicates an appreciable groundwater nitrate contribution to the CO-SW5 site, which is downstream from the agricultural fields that receive land-applied biosolids, and is consistent with the groundwater data. Total nitrogen concentrations were statistically higher in storm samples at the CA-SW1 and CO-SW1 sites, but there is no statistical difference between baseflow and storm samples at the CO-SW5 site and is directly related to the relatively high baseflow nitrate concentrations at CO-SW5. Concentrations of organic nitrogen and TP were higher and statistically different in storm samples at all three surface-water monitoring sites, likely reflecting increased input of organic material and particle-associated phosphorus during storms. Concentrations of E. coli and fecal coliform bacteria were higher by orders of magnitude and statistically different in storm samples at the three sites compared to baseflow samples. Calcium, chloride, and sodium concentrations were all higher and statistically different in baseflow samples than storm samples at all three sites, and potassium concentrations were higher and statistically different in storm samples than baseflow samples for the three sites. 
Surface-water sample results were analyzed by two seasonal groupings - winter/spring and summer/fall- to determine if there were statistically significant variations between the seasonal groupings at the three monitoring sites. Given the relatively few samples collected in the summer and fall seasons because of dry conditions, the grouping of multiple seasons was required to have an adequate number of samples in the summer/fall to conduct the statistical analysis. There were no statistically significant differences in concentrations between winter/spring and summer/fall for nitrate, organic nitrogen, total nitrogen, and calcium. Concentrations of $E$. coli and fecal coliform bacteria, TP, and potassium were higher and statistically different in the summer/fall than in the winter/spring period. The results for bacteria are likely related to warmer water temperatures and lower flow conditions, and the phosphorus and potassium results are likely related to the higher intensity rainfall that occurs during the summer/fall season, which tends to cause more erosion and mobilization of sediment-bound phosphorus and potassium. To support this hypothesis, potassium is the only cation that had higher concentrations during storms relative to baseflow. Alternatively, concentrations of the cations chloride and sodium were higher in the winter/spring than in the summer/fall, which may in part be related to the use of deicers, but is most likely related to the fact that baseflow is highest during the winter/ spring and concentrations of chloride and sodium were highest during baseflow.

With the exception of organic nitrogen concentrations in stormwater runoff, which were the highest at site CA-SW1, constituent concentrations at the CO-SW5 site were either higher and statistically different (45 percent of the comparisons) or higher but not statistically different (53 percent of the comparisons) than all corresponding concentrations at the other two monitoring sites that do not have land-applied biosolids in the contributing watersheds. For just the nutrient concentrations, the analytical results from the CO-SW5 site were higher and statistically different for 56 percent and higher but not statistically different for 38 percent of the comparisons with the other two monitoring sites. A majority of the comparisons for which the CO-SW5 site is higher and statistically different than the other sites were for baseflow conditions, which indicates the most significant difference among the sites, particularly between sites CA-SW1 and CO-SW5, is related to the groundwater contribution.

To further evaluate any differences in the surface-water quality in watersheds with and without land-applied biosolids, an analysis of the median concentrations of EPA-listed contaminants with ceiling concentrations for land-applied biosolids and nutrients was conducted. Most of the median concentrations of the constituents with EPA ceiling concentrations were less than the long-term detection levels that were established by the NCDENR water-quality laboratory that conducted the analysis of these constituents. Except for nitrate in baseflow and storm samples and TN in baseflow samples, which were appreciably higher at site CO-SW5, the median concentrations for all other constituents were either similar to or higher at the background site on Cane Creek (CA-SW1) relative to site CO-SW5.

Site CO-SW1 had the lowest median concentrations among the three monitoring sites, although except for nitrate, the median concentrations for all other constituents were similar to the other sites.

Stormwater runoff samples were collected at the three monitoring sites for three storm events that occurred soon after the land application of biosolids occurred. Samples were collected in the fall of 2011 and 2012 and analyzed for contaminants of emerging concern (household-, industrial, and agricultural-use compounds, sterols, pharmaceuticals, hormones, and antibiotics). Contaminants of emerging concern were detected more frequently in surface water than in the shallow groundwater. Overall, household-, industrial-, and agricultural-use compounds were detected most frequently in the surface-water samples ( 3 to 13 percent detections) followed by sterols ( 1 to 6 percent detections), and there were few detections of pharmaceuticals, hormones, and antibiotics ( 0 to 2 percent detections). It is important to note that the analytical variability for contaminants of emerging concern in surface water is unknown, and analytical recovery of about half of the household-, industrial-, and agricultural-use compounds and all the pharmaceuticals in surface-water samples was poor (less than 70 percent or greater than 130 percent). The background site on Cane Creek (CA-SW1) had the most total detections (47) followed by CO-SW5 (37) and CO-SW1 (33), and the detections at all sites were at low levels, typically at or just above the reporting levels. Although these results represent a relatively small number of sampling events, the storm events occurred soon after biosolids were land-applied in the fall of 2011 and 2012. In addition, the storm event samples collected on November 4, 2011, and December 26, 2012, represent the first major runoff events that occurred after biosolids were applied to the fields in the fall of those respective years and thus represent ideal conditions in which to observe potentially higher levels of contaminants of emerging concern originating from land-applied biosolids. Given the relatively large number of detected contaminants of emerging concern in the biosolids and soil samples from the land-application fields, the analytical results for surface-water samples indicate that the contaminants of emerging concern analyzed as part of this study do not appear to be good indicators of human waste contaminants derived from land-applied biosolids because the number of detections and concentrations at the background sites CA-SW1 and CO-SW1 were similar to or higher than those at the site directly downstream from the land-application fields (site CO-SW5).

Surface-water nutrient loads and yields were computed monthly, seasonally (March-May, June-August, SeptemberNovember, and December-February), and for the complete study period (March 1, 2011-May 31, 2013). Bacteria loads were computed in the same manner as nutrient loads; however, the standard error of prediction for E. coli and fecal coliform bacteria loads were large $\left(5.10 \times 10^{5}\right.$ and $3.15 \times 10^{5}$, respectively) as were the upper and lower confidence intervals as a 
result of the inherent variability in both the analytical procedures for bacteria and the relation of bacteria concentrations and streamflow. Therefore, instantaneous bacteria loads and yields were used in the analysis rather than computed monthly, seasonal, and total study period loads and yields.

The total study period nutrient yields were higher at site CO-SW5, which is downstream from the biosolids application field relative to the other two sites that did not have land application of biosolids in the contributing watersheds. Although higher at site CO-SW5, the nutrient yields at sites CO-SW5 and CA-SW1were similar, and both were appreciably higher than those at site CO-SW1. The intervening watershed between sites CO-SW1 and CO-SW5 largely comprises the biosolids application fields, many of which are home to grazing beef cattle. The nitrate, total organic nitrogen, TN, and TP yields on Collins Creek increased in excess of 1,150 percent, 52 percent, 210 percent, and 180 percent, respectively, from site CO-SW1 to CO-SW5, which illustrates the relatively large amount of nutrients, particularly in the form of nitrate that the biosolids application fields are contributing to the stream.

Seasonal nutrient loads and yields were computed and analyzed to evaluate the temporal differences in delivery of nutrients to surface water between the monitoring sites. The nutrient loads and yields were highest for the March-May seasonal periods at all three sites followed closely by the December-February period. These two seasonal periods have the highest streamflow yields and the least amount of tree and plant nutrient uptake, which corresponds to higher nutrient delivery to the streams. To further compare the nutrient delivery among the monitoring sites, the relation between nutrient yield and streamflow yield was inspected for each site and for a given seasonal streamflow yield. Site CO-SW5 had a higher seasonal constituent yield for all the nutrients relative to sites CO-SW1 and CA-SW1.

Instantaneous bacteria loads were calculated from the measurements of bacteria concentrations and instantaneous discharge. It is important to note that bacteria concentrations and loads tend to be the highest for storm events that were preceded by extended low-flow periods and (or) dry channel conditions. Given that the chemical analysis of biosolids source material and soil from the agricultural fields shows very low or nondetectable bacteria concentrations and cattle graze on agricultural fields in both the Cane Creek and Collins Creek watersheds and there is visual evidence of cattle physically entering Collins Creek between site CO-SW1 and site CO-SW5, it is plausible that the source of the high bacteria concentrations and yields at site CO-SW5 is cattle and not land-application of biosolids.

Analysis for $\mathrm{CF} 128$ biomarkers (found to be associated with cattle manure from the biosolids application fields) from seven selected stormwater runoff samples from Collins Creek and Cane Creek with the highest bacteria concentrations indicate that three of the samples (all of which were collected from the CO-SW5 site on Collins Creek) had positive returns. Samples from Cane Creek (CA-SW1) with elevated bacteria concentrations similar to those in Collins Creek downstream from the biosolids application fields (site CO-SW5) did not show positive returns for the CF128 biomarker. This finding indicates that for the surface-water samples with the highest bacteria concentrations, the cattle grazing in and around the main stem and tributaries to Collins Creek on the OWASA biosolids land-application fields are likely the predominant source of elevated bacteria in Collins Creek downstream from the biosolids application fields. Although the CF128 biomarker was not detected in Cane Creek samples, the results do not preclude cattle from being the predominant source of elevated bacteria concentrations in Cane Creek if the sources were located further from the sampling point, which would allow for degradation of the biomarkers below the detection limits of the analyses.

Benthic-macroinvertebrate sampling was conducted on May 17, 2012, at all three monitoring sites by the NCDENR to assess any differences in stream ecologic health that could be attributed to land-applied biosolids. The benthic samples at the Collins Creek sites (CO-SW1 and CO-SW5) did not indicate any differences between the two locations. Both sites received "Poor" bioclassifications, suggesting that Collins Creek may suffer from organic pollution from sources upstream from the biosolids application fields, exacerbated by low flow and dry channels in the summer as well as fluctuations in dissolved oxygen and decreased habitat availability for benthic fauna. Drought conditions in the summer of 2011 likely further stressed the ecology of the Collins Creek watershed. The Cane Creek (CA-SW1) site received a "Good-Fair" bioclassification in 2012 as part of this study. The differences between the bioclassifications in the Cane Creek and Collins Creek watersheds are likely related to better habitats in Cane Creek (longer riffles, bank stability, and less erosion) compared to those observed in the Collins Creek watershed, but are predominantly related to flow conditions in the streams. Collins Creek went completely dry during the study period, while Cane Creek always had pooled water in the channel despite having some periods of zero flow during the drought conditions in 2011.

Overall, the most compelling conclusions of the study can be summarized by the following four points:

1. There were no exceedances of EPA ceiling concentrations for land-applied biosolids in any of the biosolids samples, and results indicate that treatment processes and storage techniques used by OWASA are effective in eliminating $E$. coli and fecal coliform bacteria from the biosolids. Copper, molybdenum, total Kjeldahl nitrogen, and TP were elevated in the soil from biosolids land-application fields relative to the background field. The relative richness of these constituents in the biosolids land-application fields is consistent with biosolids being the source of the elevated concentrations given the relatively high concentrations of these constituents in the biosolids samples that were collected.

2. Shallow groundwater in transitional zone wells, which are located adjacent to and topographically downgradient from all the biosolids-application fields, were found to be statistically different and had higher nitrate concentrations (medians greater than the EPA 
drinking-water standard of $10 \mathrm{mg} / \mathrm{L}$ ) than all the other wells sampled as part of the study.

3. Nutrient surface-water concentrations and yields (pounds per square mile), primarily nitrate, were higher at the monitoring site on Collins Creek downstream from the biosolids application fields than the other background study sites (Cane Creek and upstream Collins Creek sites). The largest differences in concentrations between sites were measured at baseflow conditions, which indicates the main cause of these differences, particularly between Cane Creek and the Collins Creek site downstream from the OWASA application fields, is related to the shallow groundwater nitrate contribution.

4. Contaminants of emerging concern were detected in biosolids for approximately 40 percent of the laboratory analyses of the samples and more frequently in soil samples from the biosolids-application fields (approximately 40 percent of analyses) relative to the soil samples from the background field (approximately 12 percent of analyses). Contaminants of emerging concern, however, do not appear to be good indicators of human-waste contaminants derived from landapplied biosolids in groundwater or surface water because the number of detections and concentrations at the background wells and surface-water monitoring sites are similar to or higher than the wells and monitoring sites that are adjacent to or downstream from the biosolids-application fields.

The data, analyses, and conclusions associated with this study can be used by regulatory agencies, resource managers, and wastewater-treatment operators to (1) better understand the quantity and characteristics of nutrients, bacteria, metals, and contaminants of emerging concern that are transported away from biosolids land-application fields to surface water and groundwater under current regulations for the purposes of establishing effective TMDLs and restoring impaired water resources, (2) assess how well existing regulations protect waters of the State and potentially recommend effective changes to regulations or land-application procedures (such the frequency, volume, and what class of biosolids that are land applied in various physiographic settings), and (3) establish a framework for developing guidance on effective techniques for monitoring and regulatory enforcement of permitted biosolids land-application fields.

\section{References}

Akaike, H., 1974, A new look at the statistical model identification: IEEE Transactions on Automatic Control, v. 19, no. 6, p. $716-723$.

Bernhard, A.E., and Field, K.G., 2000a, Identification of nonpoint sources of fecal pollution in coastal waters by using host-specific 16S ribosomal DNA markers from fecal anaerobes: Applied and Environmental Microbiology, v. 66, p. $1587-1594$.

Bernhard, A.E., and Field, K.G., 2000b, A PCR assay to discriminate human and ruminant feces on the basis of host differences in Bacteroides-Prevotella genes encoding 16S rRNA: Applied and Environmental Microbiology, v. 66, p. $4571-4574$.

Bonn, B.A., 2008, Using the U.S. Geological Survey National Water Quality Laboratory LT-MDL to evaluate and analyze data: U.S. Geological Survey Open-File Report 2008-1227, $73 \mathrm{p}$.

Bradley, P.J., and Stoddard, E.F., 2008, Geologic map of the White Cross 7.5-minute quadrangle, Orange and Chatham Counties, North Carolina: North Carolina Geological Survey Open-File Report 2008-01, 1 pl.

Bradu, D., and Mundlak, Y., 1970, Estimation in lognormal linear models: Journal of the American Statistical Association, v. 65, p. 198-211.

Burkhardt, M.R., Zaugg, S.D., Smith, S.G., and ReVello, R.C., 2006, Determination of wastewater compounds in sediment and soil by pressurized solvent extraction, solid-phase extraction, and capillary-column gas chromatography/ mass spectrometry: U.S. Geological Survey Techniques and Methods, book 5, chap B2, 33 p.

Clesceri , L.S., Greenberg, A.E., and Eaton, A.D., eds., 1998, Standard methods for the examination of water and wastewater (20th ed.): Washington, D.C., American Water Works Association, and Water Environment Federation, American Public Health Association, [variously paged].

Cohn, T.A., 2005, Estimating contaminant loads in riversAn application of adjusted maximum likelihood to type 1 censored data: Water Resources Research, v. 41, no. 7, 13 p., W07003, doi:10.1029/2004WR003833.

Cohn, T.A., Caulder, D.L., Gilroy, E.J., Zynjul, L.D., and Summers, R.M., 1992, The validity of a simple statistical model for estimating fluvial constituent loads; An empirical study involving nutrient loads entering Chesapeake Bay: Water Resources Research, v. 28, no. 9, p. 2353-2363.

Cohn, T.A., DeLong, L.L., Gilroy, E.J., Hirsch, R.M., and Wells, D.K., 1989, Estimating constituent loads: Water Resources Research, v. 25, no. 5, p. 937-942. 
Cunningham, W.L., and Daniel, C.C., 2001, Investigation of groundwater availability and quality in Orange County, North Carolina: U.S. Geological Survey Water-Resources Investigations Report 00-4286, 65 p.

Cunningham, W.L., and Schalk, C.W., comps., 2011, Groundwater technical procedures of the U.S. Geological Survey: U.S. Geological Survey Techniques and Methods 1-A1, 151 p., accessed October 16, 2014, at http://pubs.usgs.gov/tm/1a1/.

Dick, L.K., and Field, K.G., 2004, Rapid estimation of numbers of fecal Bacteroidetes by use of a quantitative PCR assay for 16S rRNA genes: Applied and Environmental Microbiology, v. 70, p. 5695-5697.

Edwards, T.K., and Glysson, G.D., 1999, Field methods for measurement of fluvial sediment: U.S. Geological Survey Techniques of Water-Resources Investigations, book 3, chap. C2, 89 p.

Federal Interagency Sedimentation Project, 2001, Operator's manual of the US DH-81 depthintegrating suspended sediment sampler, $23 \mathrm{p}$., accessed May 3, 2011, at http://fisp.wes.army.mil/ Instructions\%20US_DH-81_010612.pdf.

Fishman, M.J., ed., 1993, Methods of analysis by the U.S. Geological Survey National Water Quality LaboratoryDetermination of inorganic and organic constituents in water and fluvial sediments: U.S. Geological Survey Open-File Report 93-125, 217 p.

Fishman, M.J., and Friedman, L.C., 1989, Methods for determination of inorganic substances in water and fluvial sediments: U.S. Geological Survey Techniques of WaterResources Investigations, book 5, chap. A1, 545 p.

Foreman, W.T., Gray, J.L., ReVello, R.C., Lindley, C.E., Losche, S.A., and Barber, L.B., 2012, Determination of steroid hormones and related compounds in filtered and unfiltered water by solid-phase extraction, derivatization, and gas chromatography with tandem mass spectrometry: U.S. Geological Survey Techniques and Methods, book 5, chap. B9, 118 p.

Furlong, E.T., Noriega, M.C., Kanagy, C.J., Kanagy, L.K., Coffey, L.J., and Burkhardt, M.R., 2014, Determination of human-use pharmaceuticals in filtered water by direct aqueous injection-high-performance liquid chromatography/tandem mass spectrometry: U.S. Geological Survey Techniques and Methods, book 5, chap. B10, 49 p.
Furlong, E.T., Werner, S.L., Anderson, B.D., and Cahill, J.D., 2008, Determination of human-health pharmaceuticals in filtered water by chemically modified styrene-divinylbenzene resin-based solid-phase extraction and highperformance liquid chromatography/mass spectrometry: U.S. Geological Survey Techniques and Methods, book 5, chap. B5, $56 \mathrm{p}$.

Gesch, D.B., 2007, The national elevation dataset, in Maune, D., ed., Digital elevation model technologies and applications - The DEM users manual (2d ed.): Bethesda, Md., American Society for Photogrammetry and Remote Sensing, p. 99-118.

Gilroy, E.J., Hirsch, R.M., and Cohn, T.A., 1990, Mean square error of regression-based constituent transport estimates: Water Resources Research, v. 26, p. 2069.

Harden, S.L., Cuffney, T.F., Terziotti, Silvia, and Kolb, K.R., 2013, Relation of watershed setting and stream nutrient yields at selected sites in central and eastern North Carolina, 1997-2008: U.S. Geological Survey Scientific Investigations Report 2013-5007, 47 p. accessed October 16, 2014, at $h t t p: / / p u b s . u s g s . g o v /$ sir/2013/5007/.

Haritash, A.K., and Kaushik, C.P., 2009, Biodegradation aspects of polycyclic aromatic hydrocarbons (PAHs) - A review: Journal of Hazardous Materials, v. 169, p. 1-15.

Helsel, D.R., and Hirsch, R.M., 1992, Statistical methods in water resources: New York, N.Y., Elsevier Science Publishers, $520 \mathrm{p}$.

Kinney, C.A., Furlong, E.T., Zaugg, S.D., Burkhardt, M.R., Werner, S.L., Cahill, J.D., and Jorgensen, G.R., 2006, Survey of organic wastewater contaminants in biosolids destined for land application: Environmental Science and Technology, v. 40, p. 7207-7215.

Kruskal, W.H., and Wallis, W.A., 1952, Use of ranks in one criterion variance analysis: Journal of the American Statistical Association, v. 47, no. 260, p. 583-621.

Lee, K.E., Langer, S.K., Barber, L.B., Writer, J.H., Ferrey, M.L., Schoenfuss, H.L., Furlong, E.T., Foreman, W.T., Gray, J.L., ReVello, R.C., Martinovic, D., Woodruff, O.P., Keefe, S.H., Brown, G.K., Taylor, H.E., Ferrer, I., and Thurman, E.M., 2011, Endocrine active chemicals, pharmaceuticals, and other chemicals of concern in surface water, wastewater-treatment plant effluent, and bed sediment, and biological characteristics in selected streams, Minnesota—Design, methods, and data, 2009: U.S. Geological Survey Data Series 575, 54 p., with appendixes, accessed October 17, 2014, at http://pubs.usgs.gov/ds/575/. 
LeGrand, H.E., and Nelson, P.F., 2004, A master conceptual model for hydrogeological site characterization in the Piedmont and Mountain region of North Carolina, A guidance manual: Raleigh, North Carolina Department of Environmental and Natural Resources, Division of Water Quality, Groundwater Section, $50 \mathrm{p}$.

Lim K.J., Engel, B.A., Tang, Z., Choi, J., Kim, K., Muthukrishnan, S., and Tripathy, D., 2005, Automated Web GIS based hydrograph analysis tool, WHAT: Journal of the American Water Resources Association, v. 41, no. 6, p. 1407-1416.

Lu, Q., Zhenli, L.H., and Stoffella, P.J., 2012, Land application of biosolids in the U.S.A.-A review: Applied and Environmental Soil Science, v. 2012, doi: 10.115/2012/201462, 11 p., accessed August 1, 2014, at http://www.hindawi.com/journals/aess/2012/201462/.

Mann, H.B., and Whitney, D.R., 1947, On a test of whether one of two random variables is stochastically larger than the other: Annals of Mathematical Statistics, v. 18, no. 1, p. 50-60, accessed October 13, 2011, at http://projecteuclid. org/DPubS/Repository/1.0/Disseminate? view $=$ body\&id $=p d$ $f \_1$ \&handle $=$ euclid.aoms $/ 1177730491$.

McKinney, C.W., Loftin, K.A., Meyer, M.T., Davis, J.G., and Pruden, A., 2010, tet and sul antibiotic resistance genes in livestock lagoons of various operation type, configuration, and antibiotic occurrence: Environmental Science and Technology, v. 44, p. 6102-6109.

Meyer, M.T., Lee, E.A., Ferrell, G.F., Bumgarner, J.E., and Varns, J., 2007, Evaluation of offline tandem and online solid-phase extraction with liquid chromatography/electrospray ionization-mass spectrometry for analysis of antibiotics in ambient water and comparison to an independent method: U.S. Geological Survey Scientific Investigations Report 2007-5021, 28 p.

Mueller, D.S., Wagner, C.R., Rehmel, M.S., Oberg, K.A., and Rainville, Francois, 2013, Measuring discharge with acoustic Doppler current profilers from a moving boat (ver. 2.0, December 2013): U.S. Geological Survey Techniques and Methods, book 3, chap. A22, 95 p., accessed October 28, 2014, at http://dx.doi.org/10.3133/tm3A22.

Munsell Soil-Color Charts, 2009, revised: Munsell Color, $430044^{\text {th }}$ Street, Grand Rapids, Mich.

National Research Council of the National Academy of Sciences, 2002, Biosolids applied to land: Washington, D.C., National Academies Press.

Natural Resources Conservation Service, n.d.[a], Estimating moist bulk density by texture, U.S. Department of Agriculture, Soils, Web site, accessed October 14, 2014, at $h t t p: / / w w w . n r c s . u s d a . g o v / w p s / p o r t a l / n r c s / d e t a i l / s o i l s /$ survey/office/ssr10/tr/?cid=nrcs144p2_074844.
Natural Resources Conservation Service, n.d.[b], Web soil survey, U.S. Department of Agriculture, accessed March 6, 2014, at http://websoilsurvey.nrcs.usda.gov/app/.

North Carolina Department of Environment and Natural Resources (NCDENR), Division of Water Quality, 1999, Biological Assessment Report, Cape Fear River Basin, June 1999, accessed November 28, 2014, at http://portal.ncdenr.org/web/wq/ess/reports

North Carolina Department of Environment and Natural Resources (NCDENR), Division of Water Quality, 2009, Biocriteria for the small streams of the North Carolina Mountains and Piedmont: Memorandum, May 29, 2009, accessed November 28, 2014, at http://portal.ncdenr.org/c/ document_library/get file? unid=2d54ad23-0345-4d6e82fd-04005f48eaa7\&groupId $=38364$.

North Carolina Department of Environment and Natural Resources (NCDENR), Division of Water Resources, 2013, Standard operating procedures for collection and analysis of benthic macroinvertebrates (ver. 4.0): North Carolina Department of Environment and Natural Resources, Division of Water Resources, Environmental Sciences Section, Biological Assessment Branch, $52 \mathrm{p}$.

North Carolina Department of Environment and Natural Resources (NCDENR), Division of Water Resources, 2014, Ground water level access page, accessed February 3, 2014, at http://www.ncwater.org/Data_and_Modeling/Ground_ Water_Databases/wellaccess.php.

North Carolina Department of Environment and Natural Resources (NCDENR), Division of Water Resources, n.d.[a], Jordan Lake rules, accessed March 2014, at http://jordanlake.org/.

North Carolina Department of Environment and Natural Resources (NCDENR), Division of Water Resources, n.d.[b], North Carolina water quality classifications by North Carolina river basin, accessed March 2014, at http://portal.ncdenr.org/web/wq/ps/csu/classifications.

North Carolina Department of Environment and Natural Resources (NCDENR), Division of Water Resources, n.d.[c], Water quality permitting, accessed October 3, 2014, at http://portal.ncdenr.org/web/wq/aps/lau/ programs\#Residuals.

Oklahoma Department of Environmental Quality, 1996, Methods 8020/8015 (modified) gasoline range organics (GRO), rev. 4.0: Oklahoma City, Okla., Oklahoma Department of Environmental Quality, 12 p. 
Patton, C.J., and Kryskalla, J.R., 2003, Methods of analysis by the U.S. Geological Survey National Water Quality Laboratory, Evaluation of alkaline persulfate digestion as an alternative to Kjeldahl digestion for determination of total and dissolved nitrogen and phosphorus in water: U.S. Geological Survey, Water-Resources Investigations Report 03-4174, 33 p.

Patton, C.J., and Kryskalla, J.R., 2011, Colorimetric determination of nitrate plus nitrite in water by enzymatic reduction, automated discrete analyzer methods: U.S. Geological Survey Techniques and Methods, book 5, chap. B8, 34 p.

Patton, C.J., and Truitt, E.P., 2000, Methods of analysis by the U.S. Geological Survey National Water Quality Laboratory-Determination of ammonium plus organic nitrogen by a Kjeldahl digestion method and an automated photometric finish that includes digest cleanup by gas diffusion: U.S. Geological Survey Open-File Report 00-170, 31 p.

Rantz, S.E., and others, 1982, Measurement and computation of streamflow, vols. 1 and 2: U.S. Geological Survey WaterSupply Paper 2175, 631 p.

Rogers, S.W., Donnelly, M., Peed, L., Mondal, S., Zhang, Z., and Shanks, O., 2011, Decay of bacterial pathogens, fecal indicators, and real time quantitative PCR genetic markers in manure-amended soils: Applied and Environmental Microbiology, v. 77, p. 4839-4848.

Rudo, K., 2005, Human health risk evaluation of the land application of sewage sludge/biosolids: North Carolina Department of Health and Human Services, Occupational and Environmental Epidemiology Branch, 22 p.

Runkel, R.L., Crawford, C.G., and Cohn, T.A., 2004, Load Estimator (LOADEST) - A FORTRAN program for estimating constituent loads in streams and rivers: U.S. Geological Survey Techniques and Methods, book 4, chap. A5, $69 \mathrm{p}$.

Schultz, M.M., and Furlong, E.T., 2008, Trace analysis of antidepressant pharmaceuticals and their select degradates in aquatic matrixes by LC/ESI/MS/MS: Analytical Chemistry, v. 80, p. $1756-1762$.

Shanks O.C., Atikovic, E., Blackwood, A.D., Lu, J., Noble, R.T., Santo Domingo, J., Seifring, S., Sivaganesan M., and Haugland R.A., 2008, Quantitative PCR for detection and enumeration of genetic markers of bovine fecal pollution: Applied and Environmental Microbiology, v. 74, p. 745-752.

Shanks O.C., Kelty C.A., Sivaganesan M., Varma M., and Haugland R.A., 2009, Quantitative PCR for genetic markers of human fecal pollution: Applied and Environmental Microbiology, v. 75, p. 5507-5513.
Soil Survey Division Staff, 1993, Soil survey manual: U.S. Department of Agriculture, Soil Conservation Service, Handbook 18, accessed October 17, 2014, at http://www.nrcs.usda.gov/wps/portal/nrcs/detail/soils/ survey/? cid $=$ nrcs142p2_054262.

Soil Survey Staff, 1999, Soil taxonomy-A basic system of soil classification for making and interpreting soil surveys ( $2 \mathrm{~d}$ ed.): U.S. Department of Agriculture, Natural Resources Conservation Service, Handbook 436, accessed October 17, 2014, at http://www.nrcs.usda.gov/wps/portal/ nrcs/detail/soils/survey/?cid=nrcs142p2_053577.

Tucker, M.R., 1999, Essential plant nutrients - Their presence in North Carolina soils and role in plant nutrition, accessed October 17, 2014, athttp://www.ncagr.gov/agronomi/ pdffiles/essnutr.pdf.

Tukey, J.W., 1977, Exploratory data analysis: Reading, Mass., Addison-Wesley Publishing, 506 p.

Turnipseed, D.P., and Sauer, V.B., 2010, Discharge measurements at gaging stations: U.S. Geological Survey Techniques and Methods, book 3, chap. A8, 87 p. (Also available at http://pubs.usgs.gov/tm/tm3-a8/.)

U.S. Environmental Protection Agency, 1974, Phosphorus, total, (colorimetric, automated, block digester AA II), method 365.4: Cincinnati, Ohio, U.S. Environmental Protection Agency, Environmental Monitoring Systems Laboratory, Office of Research and Development, 5 p.

U.S. Environmental Protection Agency (EPA), 1993, Determination of phosphorus by semi-automated colorimetry, rev. 2.0, method 365.1: Cincinnati, Ohio, U.S. Environmental Protection Agency, Environmental Systems Monitoring Laboratory, Office of Research and Development, $17 \mathrm{p}$.

U.S. Environmental Protection Agency, 1994a, A plain English guide to EPA Part 503 Biosolids Rule: Washington, D.C., U.S. Environmental Protection Agency, Office of Wastewater Management, $176 \mathrm{p}$.

U.S. Environmental Protection Agency (EPA), 1994b, Determination of metals and trace elements in water and wastes by inductively coupled plasma-atomic emission spectrometry, rev. 4.4, method 200.7: Cincinnati, Ohio, U.S. Environmental Protection Agency, Environmental Monitoring Systems Laboratory, Office of Research and Development, 58 p.

U.S. Environmental Protection Agency (EPA), 1994c, Determination of trace elements in waters and wastes by inductively coupled plasma-mass spectrometry, rev. 5.4, method 200.8: Cincinnati, Ohio, U.S. Environmental Protection Agency, Environmental Monitoring Systems Laboratory, Office of Research and Development, $57 \mathrm{p}$. 
U.S. Environmental Protection Agency (EPA), 1994d, Determination of mercury in water by cold vapor atomic absorption spectrometry, rev. 3.0, method 245.1: Cincinnati, Ohio, U.S. Environmental Protection Agency, Environmental Monitoring Systems Laboratory, Office of Research and Development, $18 \mathrm{p}$.

U.S. Environmental Protection Agency (EPA), 1994e, Determination of trace elements by stabilized temperature graphite furnace atomic absorption, rev. 2.2, method 200.9: Cincinnati, Ohio, U.S. Environmental Protection Agency, Environmental Monitoring Systems Laboratory, Office of Research and Development, $42 \mathrm{p}$.

U.S. Environmental Protection Agency (EPA), 1994f, Determination of total Kjeldahl nitrogen by semi-automated colorimetry, rev. 2.0, method 351.2: Cincinnati, Ohio, U.S. Environmental Protection Agency, Environmental Monitoring Systems Laboratory, Office of Research and Development, $15 \mathrm{p}$.

U.S. Environmental Protection Agency, 1995, Process design manual—Land application of sewage sludge and domestic septage: Cincinnati, Ohio, U.S. Environmental Protection Agency, Office of Research and Development, National Risk Management Research Laboratory, Center for Environmental Research Information, EPA/625/R-95/001, accessed October 17, 2014, at http://nepis.epa.gov/Adobe/PDF/30004O9U.pdf.

U.S. Environmental Protection Agency (EPA), 1996a, Test methods for evaluating solid waste, SW-846, 846 (3d ed.), update IV; method 8021B, aromatic and halogenated volatiles by gas chromatography using photoionization and/or electrolytic conductivity detectors, rev. 2: Washington, D.C., U.S. Environmental Protection Agency, 19 p.

U.S. Environmental Protection Agency (EPA), 1996b, Test methods for evaluating solid waste, SW-846, 846 (3d ed.), update IV; method 8015B, nonhalogenated organics using GC/FID, rev. 2: Washington, D.C., U.S. Environmental Protection Agency, 28 p.

U.S. Environmental Protection Agency (EPA), 1996c, Test methods for evaluating solid waste, physical/chemical methods, SW-846 (3d ed.), update IV; method 6020A, inductively coupled plasma-mass spectrometry: Washington, D.C., U.S. Environmental Protection Agency, 30 p.

U.S. Environmental Protection Agency (EPA), 1996d, Test methods for evaluating solid waste, SW-846, 846 (3d ed.), update IV; method 6010B, inductively coupled plasmaatomic emission spectrometry: Washington, D.C., U.S. Environmental Protection Agency, $25 \mathrm{p}$.
U.S. Environmental Protection Agency (EPA), 1996e, Test methods for evaluating solid waste, physical/chemical methods, SW-846 (3d ed.), update IV; method 7471B, mercury in solid or semisolid waste (manual cold vapor technique): Washington, D.C., U.S. Environmental Protection Agency, $11 \mathrm{p}$.

U.S. Environmental Protection Agency (EPA), 1998, Method 9071B, n-Hexane-extractable material (HEM) for sludge, sediment, and solid samples, rev. 2: U.S. Environmental Protection Agency, 13 p.

U.S. Environmental Protection Agency (EPA), 1999, Method 1664, Revision A-n-Hexane extractable material (HEM; oil and grease) and silica gel treated n-Hexane extractable material (SGT-HEM; non-polar material) by extraction and gravimetry: U.S. Environmental Protection Agency, 23 p.

U.S. Environmental Protection Agency, 2009, Targeted national sewage sludge survey report, EPA 822-R-08-014, accessed October 17, 2014, at http://earth1.epa.gov/waterscience/ biosolids/tnsss-overview.html\#results.

U.S. Geological Survey, 2005, Collection, quality assurance, and presentation of precipitation data: U.S. Geological Survey, Office of Surface Water Technical Memorandum No. 2006.01 (revised December 2009), 29 p., accessed October 17, 2014, at http://water.usgs.gov/admin/memo/SW/ OSW_2006-01_Revised_02122010.pdf.

U.S. Geological Survey, 2006, Collection of water samples (ver. 2.0): U.S. Geological Survey Techniques of WaterResources Investigations, book 9, chap. A4, accessed October 20, 2011, at http://pubs.water.usgs.gov/twri9A4/.

U.S. Geological Survey, 2010a, North Carolina Water Science Center operating procedures and guidelines, Chapter BQuality assurance plan for water-quality activities of the North Carolina Water Science Center, available at the South Atlantic Water Science Center office, Raleigh, NC.

U.S. Geological Survey, 2010b, North Carolina Water Science Center operating procedures and guidelines, Chapter CQuality assurance plan for surface-water activities of the North Carolina Water Science Center, available at the South Atlantic Water Science Center office, Raleigh, NC.

U.S. Geological Survey, 2012, Water-resources data for the United States, Water Year 2012, Water-Data Report WDR-US-2012, accessed October 17, 2014, at http://wdr.water.usgs.gov/wy2012/search.jsp.

U.S. Geological Survey, variously dated, National field manual for the collection of water-quality data: U.S. Geological Survey Techniques of Water-Resources Investigations, book 9, chaps. A1-A9, accessed October 17, 2014, at http://pubs.water.usgs.gov/twri9A. 
Yager, T.J.B., Furlong, E.T., Kolpin, D.W., Kinney, C.A., Zaugg, S.D., and Burkhardt, M.R., 2014, Dissipation of contaminants of emerging concern in biosolids applied to nonirrigated farmland in eastern Colorado: Journal of the American Water Resources Association, v. 50, no. 2, p. 343-357.

Yager, T.J.B., Smith, D.B., and Crock, J.G., 2004, Effects of surface applications of biosolids on soils, crops, ground water, and streambed sediment near Deer Trail, Colorado, 1999-2003: U.S. Geological Survey Scientific Investigations Report 2004-5289, 93 p.

Zaugg, S.D., Smith, S.G., and Schroeder, M.P., 2006, Methods of analysis by the U.S. Geological Survey National Water Quality Laboratory-Determination of wastewater compounds in whole water by continuous liquid-liquid extraction and capillary-column gas chromatography/mass spectrometry: U.S. Geological Survey Techniques and Methods, book 5, chap. B4, 30 p.

Zublena, J.P., Baird, J.V., and Lilly, J.P., 1991, Nutrient content of fertilizer and organic materials: North Carolina Cooperative Extension Service, AG-439-18. 
Approved for publication December 29, 2014

For further information about this publication contact:

Director

U.S. Geological Survey

South Atlantic Water Science Center

3916 Sunset Ridge Road

Raleigh, NC 27607

http://nc.water.usgs.gov/

Prepared by the Raleigh Publishing Service Center 


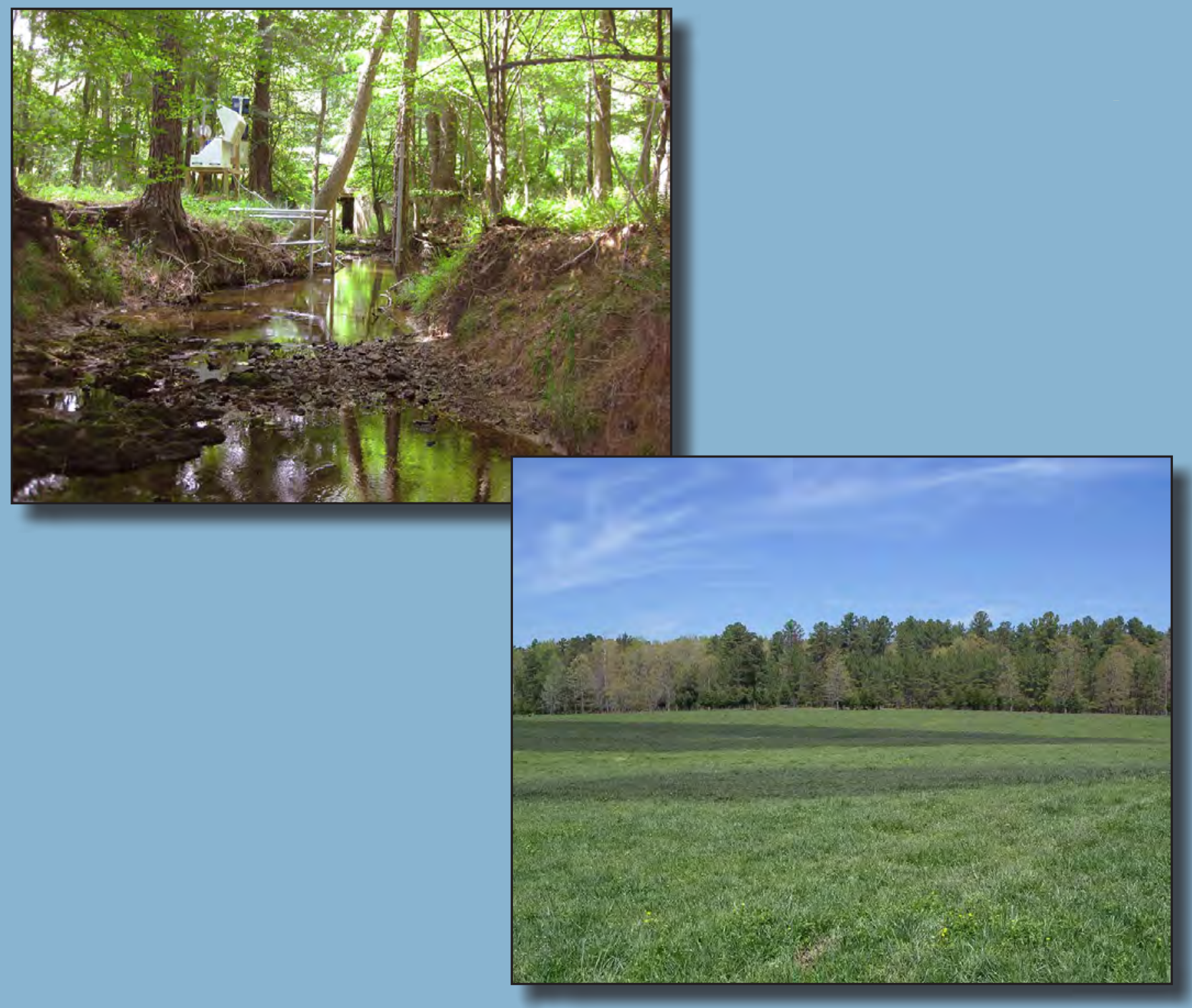

